\title{
Hydrogeologic and Water-Quality Data for the East Management Unit of Dover Air Force Base, Kent County, Delaware, 1995-96
}

By Joseph E. Beman, Daniel J. Phelan, Joel E. Dysart, Martha L. Cashel and Vanessa C. Smith

Open-File Report 99-253

In cooperation with the

THE UNITED STATES AIR FORCE 


\section{U.S. Department of the Interior \\ BRUCE BABBITT, SECRETARY}

\section{U.S. Geological Survey}

Charles G. Groat, Director

The use of trade, product, or firm names in this report is for descriptive purposes only and does not imply endorsement by the U.S. Geological Survey.

United States Government Printing Office: 1999

For additional information contact:

District Chief

U.S. Geological Survey, WRD

8987 Yellow Brick Road

Baltimore, Maryland 21237

Copies of this report can be purchased from:

U.S. Geological Survey

Branch of Information Services

Box 25286

Denver, CO 80225-0286 


\section{CONTENTS}

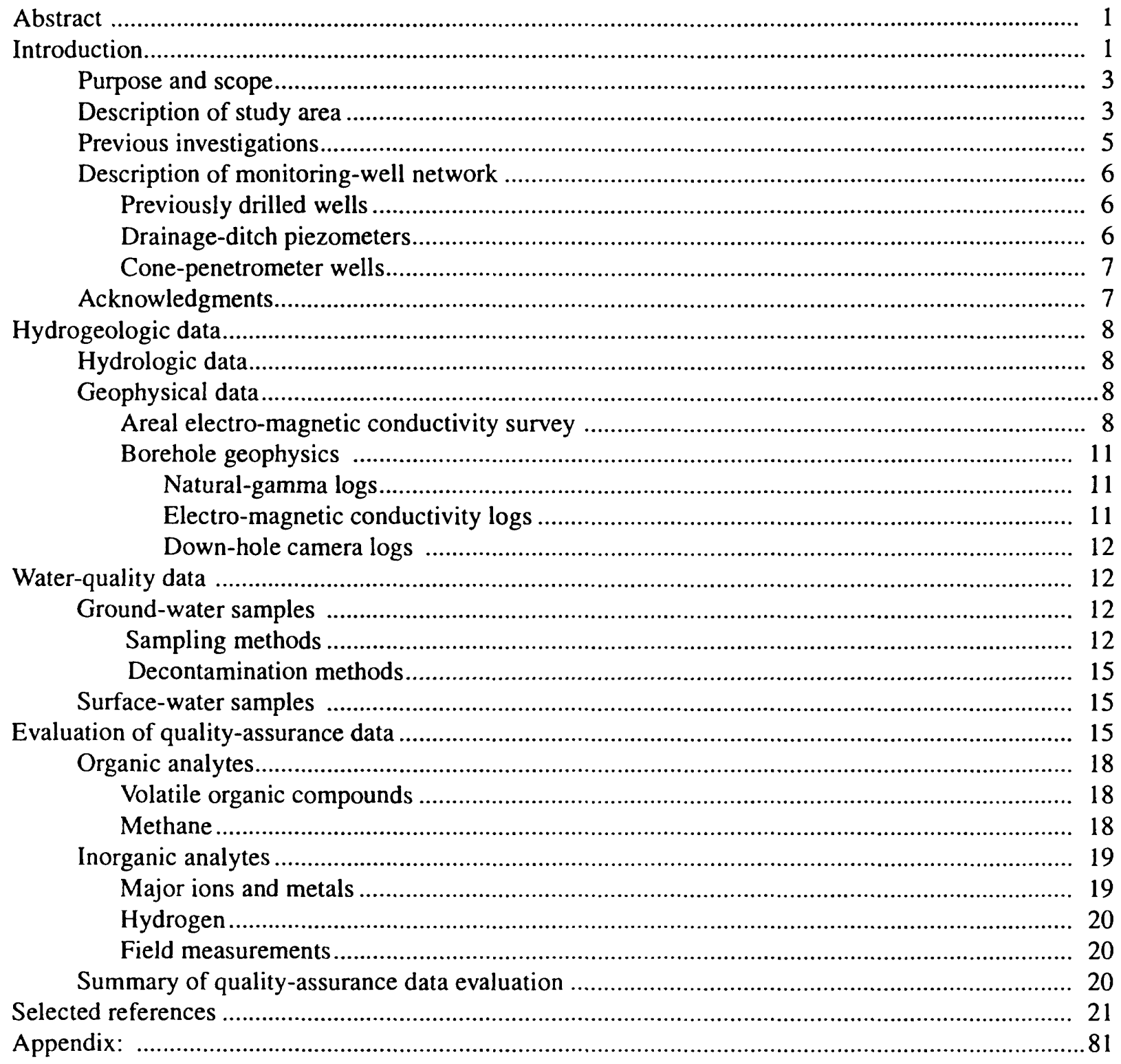

Graphs showing geophysical logs at the natural-attenuation study area, Dover Air Force Base, Delaware, for well:

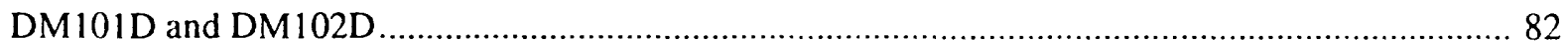

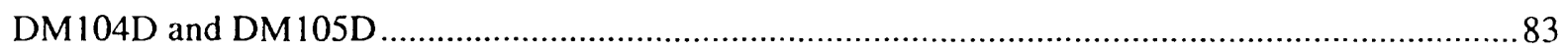

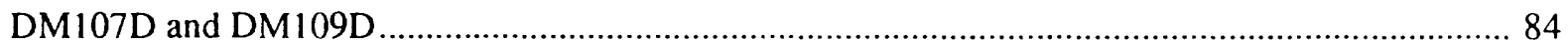

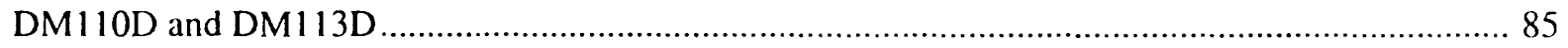

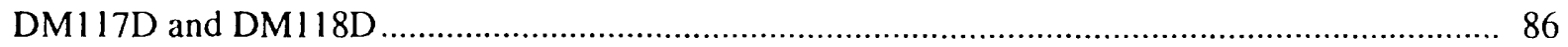

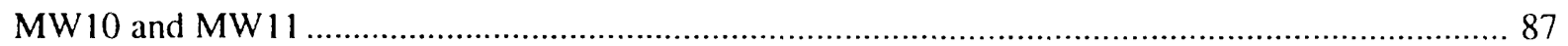

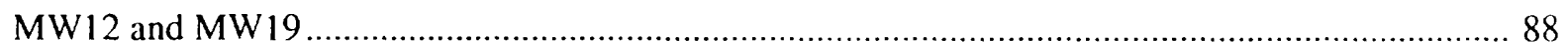




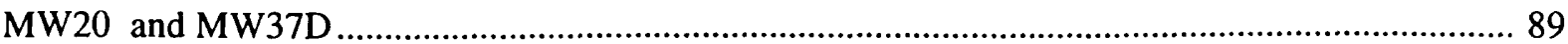

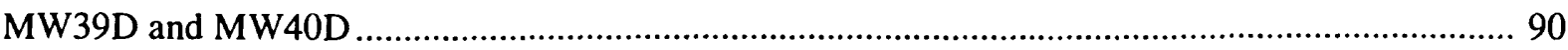

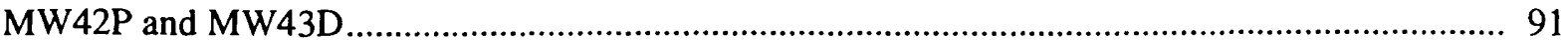

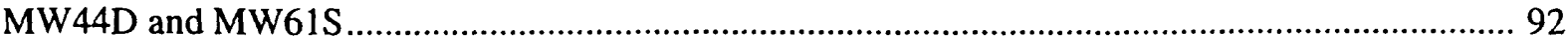

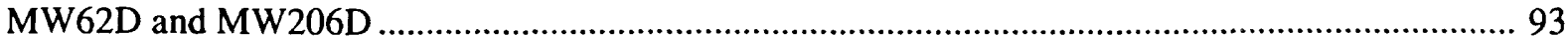

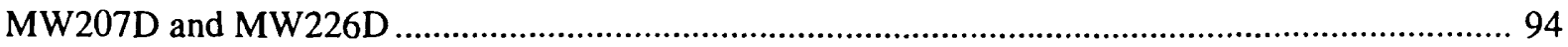

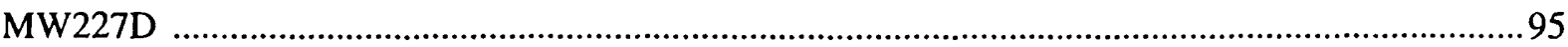

\section{FIGURES}

Figure1. Map showing location of the natural-attenuation study area at Dover Air Force Base, Kent County, Delaware

2. Map showing location of study sites, previously drilled wells, drainage-ditch piezometers, and cone-penetrometer wells at the natural-attenuation study area, Dover Air Force Base, Kent County, Delaware 4

3. Hydrograph showing daily mean water-level elevations at the natural-attenuation study area, Dover Air Force Base, Kent County, Delaware, from October 1995 through December 1996 in:

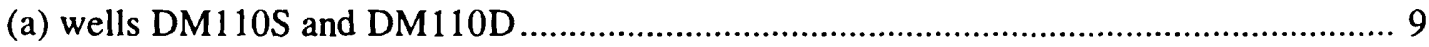

(b) piezometers GS4S and GS4D, and Pipe Elm Branch ............................................. 9

4. Map showing the location and site numbers of the areal electro-magnetic conductivity survey at the natural-attenuation study area, Dover Air Force Base, Kent County,

Delaware, March 1996.

5. Map showing the locations of wells and piezometers sampled during July-August 1995 , May-July 1996, and August 1996 at the natural-attenuation study area, Dover Air Force Base, Kent County, Delaware.

6. Map showing the locations of surface-water sites sampled during 1995 and 1996 at the natural-attenuation study area, Dover Air Force Base, Kent County, Delaware

\section{TABLES}

Table 1. Well-construction data and types of geophysical logs available for monitoring wells at the natural-attenuation study area, Dover Air Force Base, Kent County,

Delaware

2. Daily mean water-level elevations in wells DM110D and DM110S, piezometers GS4D and GS4S, and Pipe Elm Branch, Dover Air Force Base, Kent County, Delaware, October 1995 through December 1996

3. Measured ground- and surface-water level elevations at the natural-attenuation study area, Dover Air Force Base, Kent County, Delaware, July 1995 through September 1996 
4. Areal electro-magnetic conductivity survey data at the natural-attenuation study area, Dover Air Force Base, Kent County, Delaware, March 1996

5-6. Ground- and surface-water quality data at the natural-attenuation study area, Dover Air Force Base, Kent County, Delaware, July-August 1995, May-July 1996, and August 1996, for:

5. Inorganic constituents.

6. Organic constituents and total dissolved carbon

7. Sample and duplicate concentrations, and relative percent differences for four volatile organic compounds at sites where concentrations exceeded the reporting limit, July 1995 through July 1996, Dover Air Force Base, Kent County, Delaware

8. Sample and duplicate concentrations, relative percent differences, and summary statistics for methane samples collected from July 1995 through July 1996, Dover Air Force Base, Kent County, Delaware

9. Sample and duplicate concentrations, relative percent differences, and summary statistics for hydrogen samples collected in August, 1996, Dover Air Force Base, Kent County, Delaware 


\begin{tabular}{lcl}
\hline Multiply & By & To obtain \\
\hline inch (in.) & 25.4 & millimeter (mm) \\
foot (ft) & 0.3048 & meter (m) \\
mile (mi) & 1.609 & kilometer $(\mathrm{km})$ \\
acre & 4,047 & square meter \\
gallon & 3.785 & liter \\
gallon per minute & 0.06308 & liter per second \\
(gal/min) & & \\
\hline
\end{tabular}

Temperature is reported in degrees Celsius $\left({ }^{\circ} \mathrm{C}\right)$, which can be converted to degrees Fahrenheit $\left({ }^{\circ} \mathrm{F}\right)$ by using the following equation: ${ }^{\circ} \mathrm{F}=1.8\left({ }^{\circ} \mathrm{C}\right)+32$.

Sea level: In this report, "sea level" refers to National Geodetic Vertical Datum of 1929--a geodetic datum derived from a general adjustment of the first-order level nets of the United States and Canada, formerly called Sea Level Datum of 1929.

Chemical concentration, specific conductance, and water temperature are reported in metric units. Aqueous chemical concentration is given in milligrams per liter $(\mathrm{mg} / \mathrm{L})$ or in micrograms per liter $(\mu \mathrm{g} / \mathrm{L})$. Milligrams per liter is a unit expressing the concentration of chemical constituents in solution as well as weight (milligrams) of solute per unit volume (liter) of water.

One thousand micrograms per liter is equivalent to one milligram per liter. For concentrations less than $7,000 \mathrm{mg} / \mathrm{L}$, the numerical value is the same as for concentrations in parts per million. Hydrogen concentrations in samples are expressed in nanomoles per liter $(\mathrm{nmol} / \mathrm{L})$.

Specific conductance of water is expressed in microsiemens per centimeter at 25 degrees Celsius $(\mu \mathrm{S} / \mathrm{cm})$, which is identical to micromhos per centimeter at 25 degrees Celsius, formerly used by the U.S. Geological Survey. 


\title{
HYDROGEOLOGIC AND WATER-QUALITY DATA FOR THE
}

\section{EAST MANAGEMENT UNIT OF DOVER AIR FORCE BASE,}

\section{KENT COUNTY, DELAWARE, 1995-96}

\author{
By Joseph E. Beman, Daniel J. Phelan, Joel E. Dysart, \\ Martha L. Cashel, and Vanessa C. Smith
}

\begin{abstract}
This report presents data collected by the U.S. Geological Survey from April 1995 through September 1996 as part of a project to assess ground- and surface-water contamination, and to determine if natural attenuation of organic contaminants is a feasible alternative to remediation at four sites in the East Management Unit of Dover Air Force Base, in Kent County, Delaware. Ground- and surface-water-level data, borehole and surface geophysical data, and ground- and surface-water quality data, and the techniques used to collect the data are presented. The water-level and water-quality sampling network for this project consisted of 11 drainage-ditch piezometers and 8 cone-penetrometer wells installed during the study, and 86 previously drilled wells. An evaluation of quality-assurance data showed that water-quality data were of good quality, there was no evidence of cross-contamination in any samples, and the data were reproducible and unbiased.
\end{abstract}

\section{INTRODUCTION}

Dover Air Force Base (DAFB) is located in Kent County, Delaware, approximately 3.5 mi southeast of the center of the City of Dover, Delaware (fig.1). DAFB began operation in 1941 at the site of the partially constructed Dover Municipal Airfield. The base was used for various purposes during and after World War II and was deactivated in 1946, only to be reactivated as Dover Air Force Base in 1950. Since then, DAFB has been supporting activities of the U.S. Air Force (USAF) Air Mobility Command.

In March 1989, DAFB was listed on the National Priorities List (NPL), which placed it under regulations described in the Comprehensive Environmental Response, Compensation, and Liability Act of 1980 (CERCLA) that governs activities at hazardous waste sites. The U.S. Geological Survey (USGS) conducted an investigation in cooperation with the Environmental Flight of the USAF to evaluate whether or not natural attenuation is a feasible alternative to remediation at disposal sites located in the East Management Unit of DAFB. This investigation was conducted in response to previous investigations that had determined sources of contamination, and the presence of contaminants in the ground- and surface-water systems in the East Management Unit. This report presents the results of the data-collection effort for that project. 


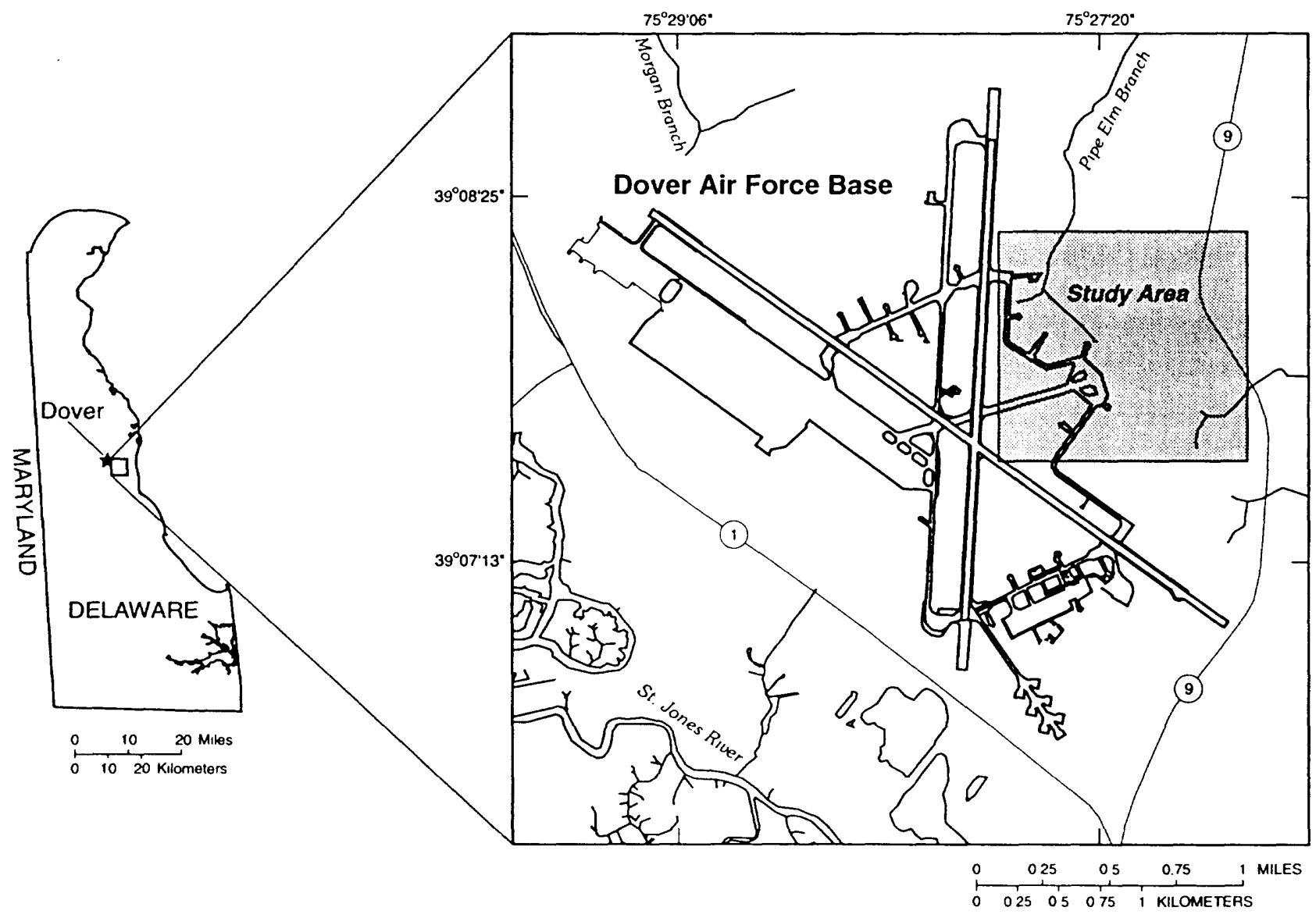

Figure 1. Location of the natural-attenuation study area at Dover Air Force Base, Kent County, Delaware. 


\section{Purpose and Scope}

The purpose of this report is to present data collected by the USGS from April 1995 through September 1996 as part of the natural-attenuation (NA) project to determine if natural attenuation of contaminants is a feasible alternative to remediation at four sites in the Eastern Management Unit of DAFB. An interpretive administrative report is being prepared concurrent with this report by the USGS. Ground- and surface-water-level data, borehole and surface geophysical data, and ground- and surface-water quality data, and the techniques used to collect the data are presented.

\section{Description of Study Area}

The topography of DAFB is flat with little spatial variation. Naturally-occurring land-surface elevations range from sea level along the St. Jones River, to about $37 \mathrm{ft}$ above sea level on the northwestern boundary of the base (fig. 1). The northwest-southeast runway has an elevation of about $28 \mathrm{ft}$ above sea level, which is higher than most of the surrounding area. Land-surface elevations in the study area of the East Management Unit range from a high of about $45 \mathrm{ft}$ atop landfill LF13, to about $3.5 \mathrm{ft}$ where Pipe Elm Branch flows across the base boundary at Postles Corner Road (fig. 2). With the exception of the landfill LF13, and the small valley along Pipe Elm Branch, land-surface elevations in the study area range from 20 to $25 \mathrm{ft}$ above sea level.

Three major hydrologic units have been identified beneath the base. The units are, in descending order, (1) the unconfined aquifer--chiefly sand units of the Columbia Group, (2) the Frederica and Cheswold confined aquifers of the Chesapeake Group, and (3) the sand units of the confined Piney Point and Magothy Formations (Leahy, 1982).

Data for the NA project were collected from four sites in the northeastern portion of DAFB. The sites are: Fire Training area 3 (FT03), Landfill 15 (LF15), Waste Pit 14 (WP14), and Landfill 13 (LF13). The locations of these sites are shown in figure 2.

Site FT03 covers approximately 1.3 acres (fig. 2). The site was used for fire training from 1970 to 1989. Fuels were ignited and extinguished as part of fire training exercises. Site FT03 was remediated in 1992, currently has a clay cap, and is covered with grass and minor gravel (Dames and Moore, written commun., 1996).

Site LF15 is two former landfills located near the receiver station (fig. 2). The site was initially reported to be an area of less than 0.5 acre; however, personnel familiar with the site described it as much larger. During the 1960's, LF15 was reportedly used for disposal of general refuse and small quantities of industrial shop wastes. Reportedly, the disposal area was filled to a depth of approximately $8 \mathrm{ft}$. When disposal activities ceased at an unknown date, the site was covered with several feet of local soil and seeded with grass. Site LF15 is currently an open, grass-covered field (Dames and Moore, written commun., 1996).

Site WP14 was used as a liquid waste-disposal trench. The site is located near the access road leading to the receiver station, and $200 \mathrm{ft}$ to the west of LF15. An individual involved in the trench's construction stated that it was $15 \mathrm{ft}$ wide by $100 \mathrm{ft}$ long by $6 \mathrm{ft}$ deep. The trench was used during the 1950's for the disposal of waste solvents, hydraulic fluids, waste oils, and other liquid wastes generated in shop operations. After disposal activities ceased at WP 14, the trench was filled with 3 to $4 \mathrm{ft}$ of local soil and seeded with grass (Dames and Moore, written commun., 1996).

Site LFI 3 is an active landfill located about 1,000 ft to the southeast of LF15. The site, which covers approximately 4 acres, is sparsely covered with small trees and underbrush, with a gravel road down the center. The landfill slopes upward to the east, with the eastern edge of the site ending abruptly at a 20 -ft- 


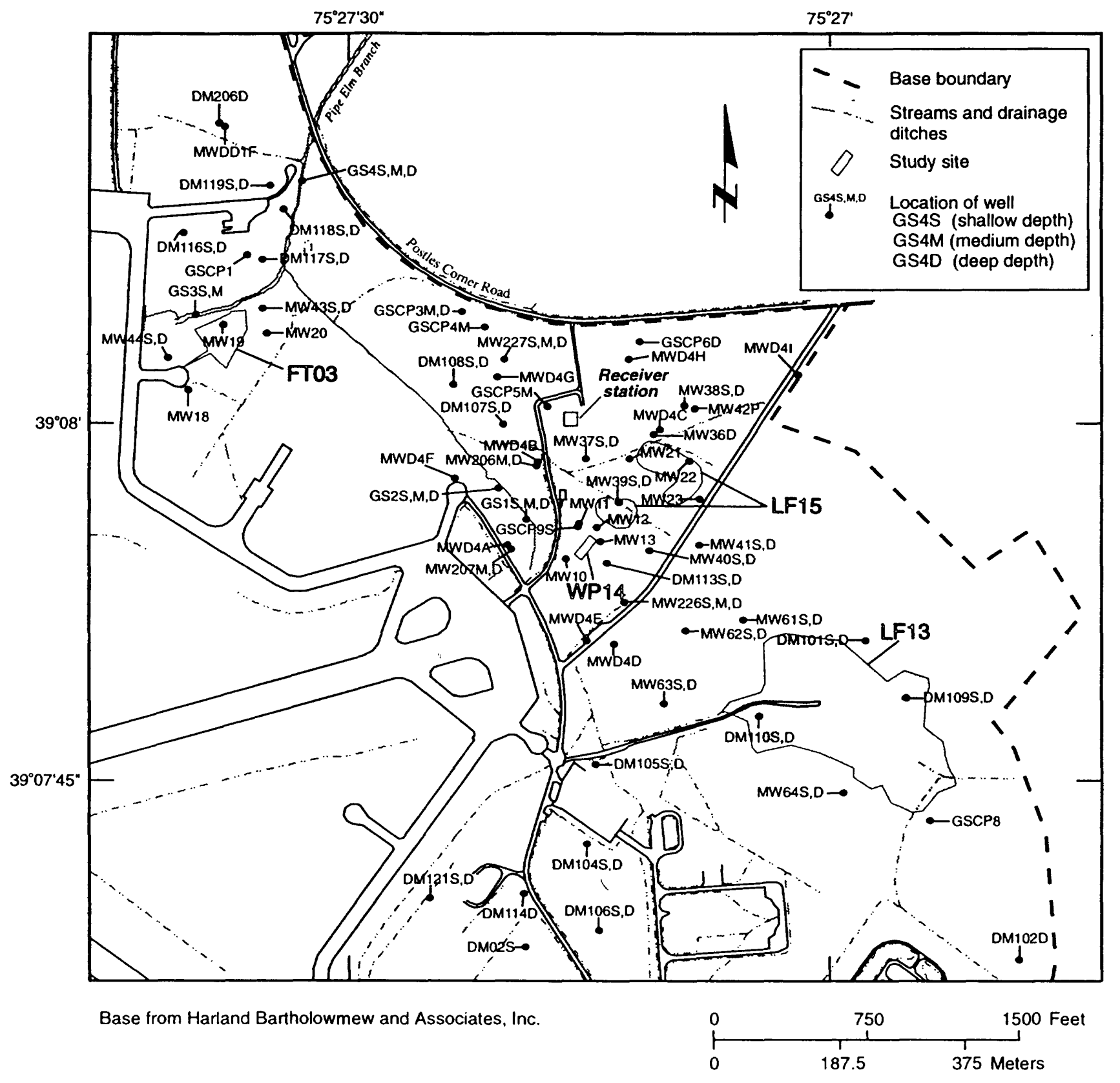

Figure 2. Location of study sites, previously-drilled wells, drainage-ditch piezometers, and conie-penetrometer wells at the natural-attenuation study area, Dover Air Force Base, Kent County, Delaware. [Well numbers for previouslydrilled wells begin with DM or MW. Site numbers for drainage-ditch piezometers begin with GS, and well numbers of cone-penetrometer wells begin with GSCP.] 
high ledge of debris and concrete. Site LF13 was used from the early to late 1960's for disposal of small quantities of general refuse and large quantities of construction rubble. At present, the site is partially covered with construction rubble such as concrete, metal scraps and cans (Dames and Moore, written commun., 1996).

\section{Previous Investigations}

All four study sites have undergone previous or concurrent investigations, including the North and East Management Units Remedial Investigation (RI) of 1993 (Dames and Moore, written commun., 1996). Other studies which were conducted at some or all of the four study sites are: Science Applications International Corporation (SAIC) (1986 and 1989), and Hazardous Waste Remedial Actions Program (HAZWRAP) (1990). The following paragraphs describe investigations which have taken place at each study site.

Two previous investigations were conducted at site FT03 by SAIC (1986 and 1989). The SAIC studies led to a focused feasibility study (FFS), and subsequent remedial oversight activities. Based on the FFS, a Record of Decision (ROD) was signed in September 1990. During the 1986 investigation, groundwater and surface-water samples were collected on and around the site upon discovering evidence of oil contamination along a bank adjacent to a drainage ditch north of the site. During the 1989 investigation, a soil gas survey was conducted to delineate concentrations of petroleum and hydrocarbons and to finalize the locations of new monitoring wells and auger borings. Soil and ground-water samples were collected to characterize ground water and to identify extent of contamination. During the 1993 study, existing monitoring wells were resampled and soil samples were collected. Ground-water samples were analyzed for volatile organic compounds (VOCs), semivolitile organic compounds (SVOCs), pesticides/polychlorinated biphenyl (PCBs), hardness, and total dissolved solids (TDS). Soil samples were analyzed for VOCs, SVOCs, metals, total petroleum hydrocarbons (TPH) and pesticides/PCBs (Dames and Moore, written commun., 1996).

Three previous investigations were conducted at site LF15 prior to the NA project: SAIC (1986 and 1989), HAZWRAP, (1990). During the 1986 investigation, three monitoring wells were installed, and ground-water samples were collected from those wells. All ground water samples were analyzed for oil and grease, cyanide and phenols, total organic carbon (TOC) and total organic halogens (TOX). During the 1989 investigation, geophysical and soil gas surveys were conducted and ground water, surface water, and sediment were sampled (SAIC, 1989). The third investigation (HAZWRAP, 1990) focused primarily on WP14, however, a soil gas survey and ground-water sampling conducted for this investigation are relevant to LF15. The soil gas survey overlapped with the western portion of LF15. During a concurrent investigation, two test pits were excavated and sampled, soil samples were collected, and all existing monitoring wells were resampled to delineate the extent of contamination at the sites (Dames and Moore, written commun., 1996).

Two previous investigations were conducted at site WP14: SAIC (1986), HAZWRAP (1990). During the 1986 investigation, four monitoring wells were installed, and ground water samples were collected from those wells. All ground-water samples were analyzed for oil and grease, cyanide, TOX, and TOC. The first ground water samples analyzed during the study were also analyzed for metals, and the second set of samples were also analyzed for VOCs. During the 1990 investigation, a soil gas survey was conuiucted to identify source areas, and soil samples were collected to determine soil quality. During a concurrent investigation, surface geophysical surveys were conducted to assess the possible presence of buried metal objects within suspected trench areas and to identify potential source areas. Soil samples were collected to test for contaminants in the soil. One monitoring well pair was installed downgradient of a trench and sampled to determine if the trench was a source of contaminants, and to delineate contaminants originating from other sources (Dames and Moore, written commun., 1996). 
Two previous investigations were conducted at site LF13 by SAIC (1986 and 1989). During the 1986 investigation, soil samples were collected from the edge of the landfill and analyzed for metals, oil and grease, TOX, total organic chloride, and TOC. During the 1989 study, surface electro-magnetic conductivity and ground-penetrating radar surveys were performed, and two well pairs were installed upgradient and two well pairs downgradient. Ground-water samples were collected from the new wells to determine if contaminants were introduced from LF13. During a concurrent investigation, 12 subsurface samples were collected from six soil borings drilled to evaluate soil conditions. Three additional monitoring well pairs were installed and sampled along with the existing wells. Surface-water and bottom-sediment samples were collected from areas north and east of LF13 to determine if activities at LF13 affected nearby surface water (Dames and Moore, written commun., 1996).

\section{Description of Monitoring-Well Network}

The water-level and water-quality sampling network for this project consisted of 11 drainage-ditch piezometers and 8 cone-penetrometer (CPT) wells installed by USGS personnel, and 86 previously drilled wells. The locations of all wells and piezometers in the monitoring-well network are shown in figure 2. Construction data for all wells and piezometers in the monitoring-well network are shown in table 1, located at the end of the report. Methods used for installing drainage-ditch piezometers and cone-penetrometer wells, and the numbering systems are described in the following sections.

\section{Previously Drilled Wells}

Fifty-four monitoring wells were installed during three previous studies--20 during HAZWRAP, (1990), and 34 by SAIC, (1986 and 1989). Thirty-two additional wells were installed during one concurrent investigation by Dames and Moore. All 86 of these wells were screened in the Columbia aquifer. The 20 vells drilled during the 1990 study by HAZWRAP were drilled using hollow-stem auger methods, and usec 2-in.-diameter polyvinyl chloride (PVC) well casings and screens (HAZWRAP, 1990). Of the 34 wells drilled during the 1986 and 1989 studies by SAIC, 33 of the 34 wells were drilled using hollow-stem auger methods and used 2-in.-diameter PVC casings and screens, and the other well (MW42P) was drilled using the hydraulic mud rotary method, with a bentonite and water mixture for the drilling mud, and was cased and screened with 4-in.-diameter PVC. The lower two-thirds of the saturated interval in well MW42P was screened to allow for an aquifer test (SAIC, 1989).

The 32 wells drilled during the concurrent study by Dames and Moore have well numbers with the prefix 'DM', and were installed in compliance with the basewide remedial investigation/feasibility study (RI/FS) work plan (WP). Shallow and deep well nests were installed in the Columbia Formation with hollow stem augering techniques. Well numbers for the shallower wells end in " $S$ ", and well numbers for the deeper wells end in "D" (e.g. DM117S and DM117D). All drilling equipment was steam cleaned prior to use and between each well boring. 2 -in.-diameter PVC casing and screen ( 0.010 or 0.020 slot size) were installed through the augers. In deep wells, the lower $10 \mathrm{ft}$ of the aquifer were screened. Shallow wells were installed such that 10 - $\mathrm{ft}$-long screens were positioned with $2 \mathrm{ft}$ of screen above the water table (Dames and Moore, written commun., 1996).

\section{Drainage-Ditch Piezometers}

Eleven drainage-ditch piezometers were installed during the summer of 1995 at four sites in the NA study area. Three sites (GS1, GS2, and GS4) have shallow, medium and deep piezometers in a nest, and one site (GS3) has shallow and medium-depth piezometers (fig. 2). Piezometers GSIS, GSIM, and GS1D represent the shallow, medium, and deepest depth screened in the nest, respectively. Each piezometer is a 2-in.-diameter stainless-steel drive point and is screened at the bottom with 0.010-in.- slot size 
screen. Screen lengths range from 0.5 to $3 \mathrm{ft}$ (table 1). Piezometers were driven using a tripod-mounted slide hammer which was raised and lowered by a manually controlled cat-head.

\section{Cone-Penetrometer Wells}

During May 1996, eight wells were installed in the study area by USGS and Applied Research Associates, Inc. (ARA) personnel using a trailer-mounted cone-penetrometer (CPT) rig owned by the USAF. Two of the eight CPT wells failed and were replaced by the USGS in July 1996 using the same CPT rig. The CPT rig was manufactured by Vertek ${ }^{1}$, weighs 12,000 pounds, and can push with a force of 30 tons when anchored. The CPT wells were installed by (1) anchoring the rig to the ground by means of four augers [ground anchors] and turnbuckles, (2) hydraulically pushing a 2.5 -in-diameter steel drive point to the desired [or maximum] depth and removing it, and (3) pushing the 2-in. PVC well screen and casing with steel rods from behind the screen's drive point to the planned depth. The PVC screens and casings, and the steel drive points and rods were steam cleaned after work at each site. The well numbers for the CPT wells begin with the letters 'GSCP' (for Geological Survey Cone Penetrometer), followed by a site number, and the letters ' $D$ ', ' $M$ ', or ' $S$ ' indicating deep, medium, or shallow depth wells, respectively.

At two sites, GSCP-1 and -5, an experimental oxidation-reduction probe operated by ARA personnel was pushed to 40 and $42 \mathrm{ft}$, respectively, prior to pushing the 2.5 -in.-diameter point. A probe that measures and records resistivity, pore pressure, sleeve stress, and tip stress was also operated by ARA personnel and was also pushed at sites GSCP $-1,-4,-5,-6,-8$, and -9 . Techniques used to measure the data during the pushes are still experimental, therefore the data are not included in this report, but are on file at the Delaware USGS office.

\section{Acknowledgments}

The authors thank the following people whose contributions made this report possible. Charles Mikula, Robert Wickso, Gregory Jackson, and Joanne Deramo of the $436^{\text {th }}$ support group, Civil Engineering Squadron, Environmental Flight of the USAF at DAFB provided logistical support and background information essential to all data-collection efforts. Michael Apgar of the Delaware Department of Natural Resources and Environmental Control (DNREC) oversaw all USGS well-installation activities. Mark Winner, Daniel Rooney, Travis Ingraham and Sean Ricker of Applied Research Associates, Inc. (ARA) operated cone-penetrometer (CPT) equipment and installed CPT wells. The authors also thank Mark Knoll, site supervisor for ARA at DAFB, for logistical support during the CPT well installations.

The following USGS personnel assisted in essential aspects of the study. Francis Chapelle, Paul Bradley, and James Landmeyer of the South Carolina District collected oxidation-reduction data presented in this report. George Zynjuk coordinated installation of piezometers and access piers. Robert Rosman and William Daniels assisted in piezometer installations and down-hole camera logging. Lisa Olsen analyzed methane samples collected during the July-August 1995 and the May-July 1996 sampling efforts. Anthony Tallman and Elizabeth Marchand aided in the field data collection and logistical coordination between the Maryland and Delaware USGS offices, and Judy Tegeler assisted in map presentation work necessary to the completion of this report. The authors also thank Peggy R. Nemoff and Donald A. Storck for thorough colleague reviews of the report.

\footnotetext{
1. Use of brand names in this report is for identification purposes only and does not constitute endorsement by the U.S. Geological Survey.
} 


\section{HYDROGEOLOGIC DATA}

Hydrologic and geophysical data collected during the USGS investigations in the study area from May 1995 through September 1996 are presented in this section.

\section{Hydrologic Data}

Continuous ground-water-level data were collected using analog to digital recorders (ADR's) that were installed on wells DM1 10S and DM110D at the LF13 site, and in piezometers GS4S and GS4D that were installed in the Pipe Elm Branch streambed near where the stream crosses the base boundary (fig. 2). A hydrograph showing daily mean ground-water elevations for wells DM110S and DM110D is shown in figure $3 a$.

An additional ADR was installed in October 1995 adjacent to piezometers GS4S, GS4M, and GS4D (fig. 2) to record the stream stage of Pipe Elm Branch. The stage data were used to determine the relation between stream stage and ground-water elevations. Discharge was not calculated from the stage data because the stream is affected by tides. A hydrograph showing ground-water elevations in piezometers GS4S and GS4D, and the elevation of the stream stage is shown in figure 3b. Daily mean water-level elevations for the four ground-water and one surface-water sites measured with the ADR's are shown in table 2 at the end of the report.

Synoptic ground-water-level measurements were made during July and December 1995, and during March, April, June, August, and September 1996. Additional water-level measurements were made during the July-August 1995 and May-July 1996 water-quality sampling periods. Periodic surface-water elevations were measured at streambed piezometers GSI, GS3, and GS4. Measured ground- and surfacewater elevations are shown in table 3.

\section{Geophysical Data}

Surface and borehole geophysical measurements were used during this study to help determine lithologic and water-quality changes in the unconfined Columbia aquifer in the study area. The following sections describe the methods and presentation of the data from those investigations.

\section{Areal Electro-Magnetic Conductivity Survey}

Areal electro-magnetic conductivity surveys were performed during March, 1996 at 126 sampling points throughout the study area. The Geonics EM-34 terrain conductivity meter was used to measure conductivity in the 20- and 10-meter vertical and horizontal dipole orientations. The instrument measures apparent conductivity in millimhos per meter. The sampling point locations and the point numbers are shown in figure 4 . The conductivity values for each data point are shown in table 4 . Instrument checks were performed each day before data collection began. The conductivity was measured for each coil orientation at site number 1 to verify that the instrument was working properly, and no problems with the calibration checks were found.

The depth of the investigation is dependent on the inter-coil spacing, the operating frequency, and the orientation of the coils. In general, when the coils are in the horizontal-dipole mode (coil oriented vertically), the instrument responds to earth materials from the surface to a depth of 0.75 times the coil spacing, and is most sensitive to the shallow subsurface layers. In the vertical-dipole mode, (coils oriented horizontally) the instrument responds to earth materials to a depth of 1.5 times the coil spacing and is most 
(a)

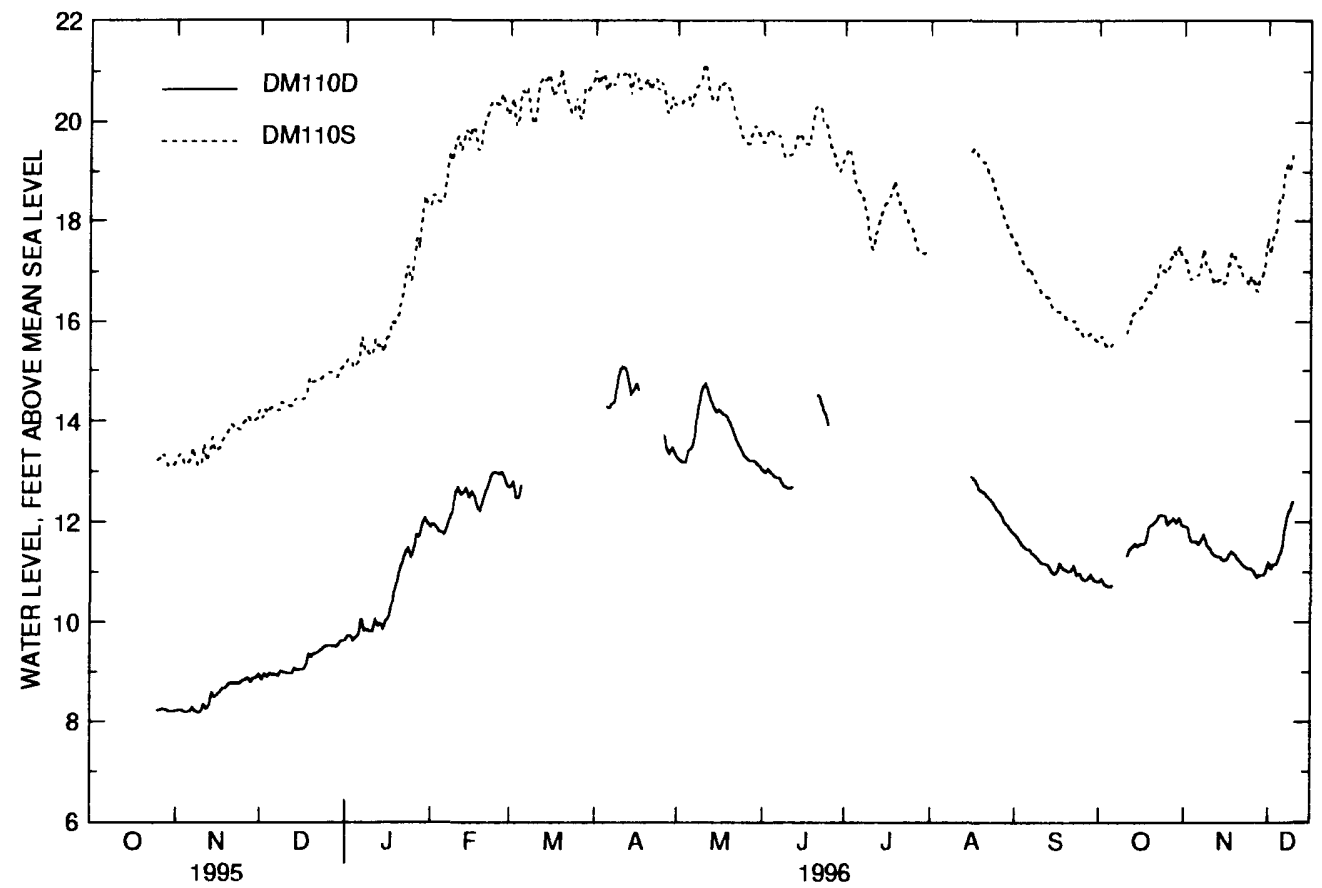

(b)

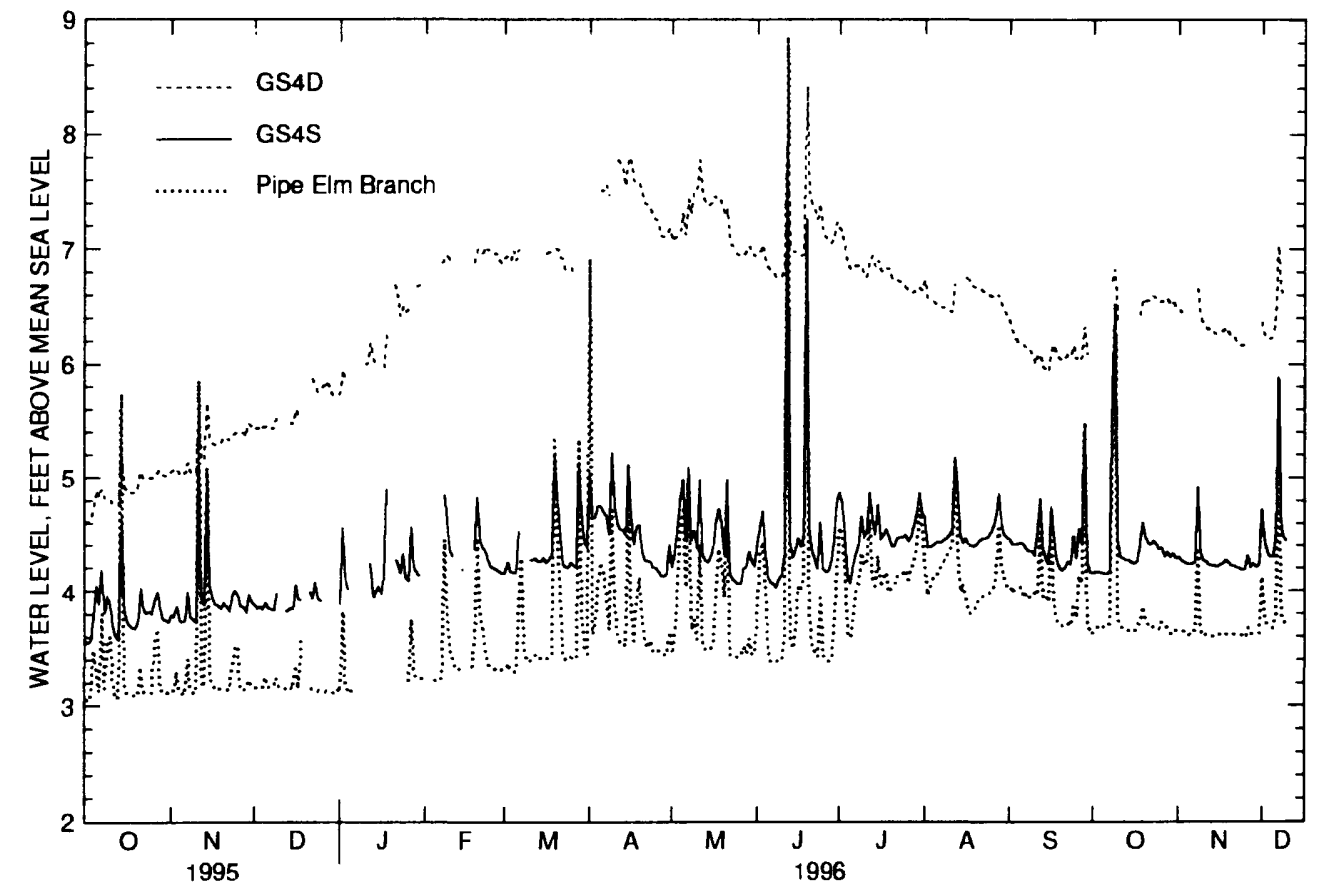

Figure 3. Hydrograph showing daily mean water-level elevations at the natural attenuation study area, Dover Air Force Base, Kent County, Delaware, from October 1995 through December 1996 in:

(a) wells DM110S and DM110D.

(b) piezometers GS4S and GS4D, and Pipe Elm Branch 


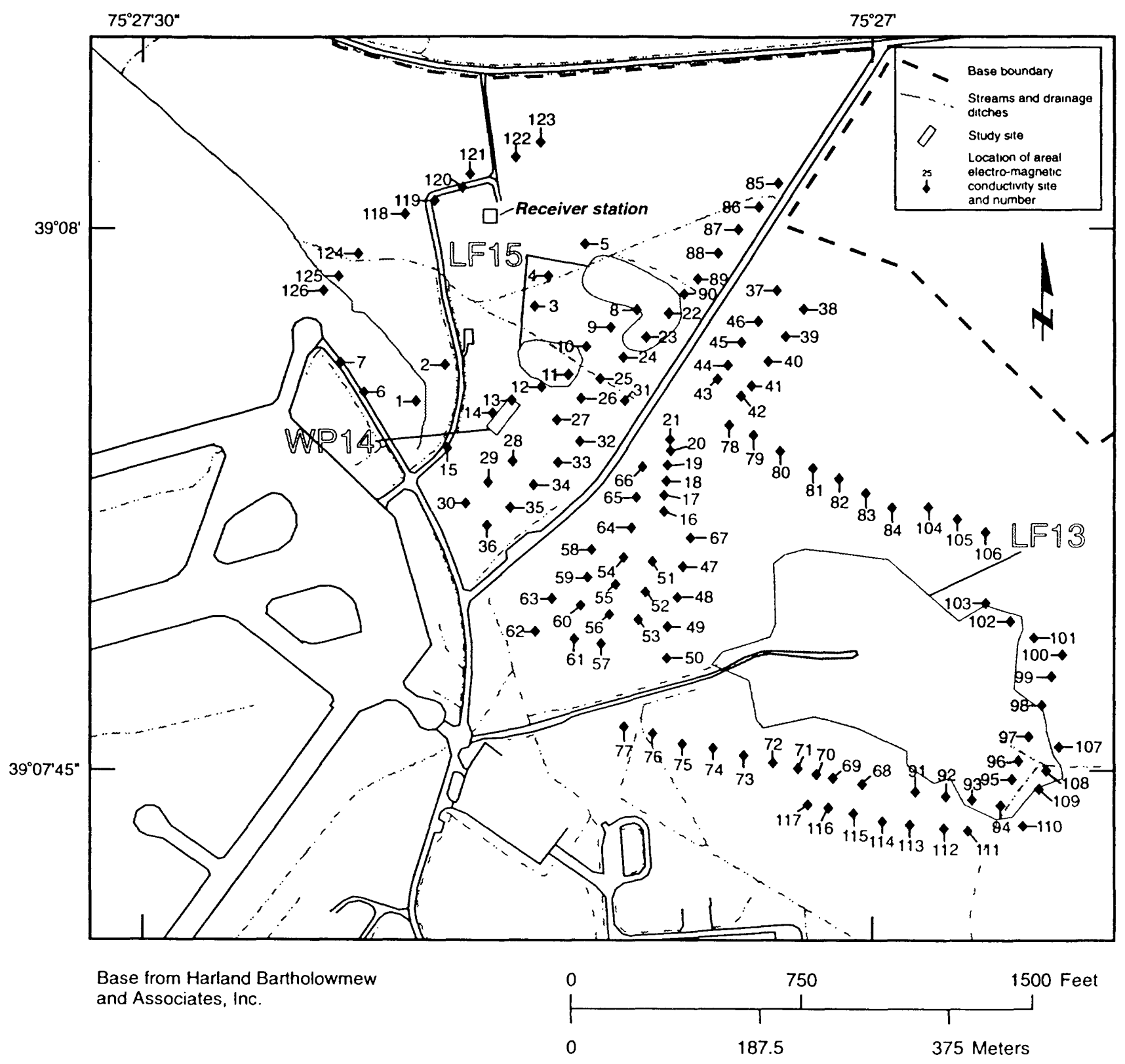

Figure 4. Location and site numbers of the areal electro-magnetic conductivity survey at the natural-attenuation study area, Dover Air Force Base, Kent County, Delaware, March 1996. 
sensitive to layers at 0.4 times that spacing. Near-surface layers have little effect on the instrument in this mode (Haeni, 1986).

\section{Borehole Geophysics}

Natural-gamma (gamma) and borehole electro-magnetic conductivity (EM) geophysical logs were obtained for 22 wells during March 1996 with a Mount Sopris portable MGX logging system. Gamma logs alone were run on an additional 5 wells during the same period. The type of logs run for each well are shown in table 1. The geophysical logs are shown in the Appendix at the end of the report.

\section{Natural-gamma logs}

Gamma logs measure the amount of naturally-occurring gamma radiation in boreholes or wells. Gamma logs are used to indicate lithologic changes. Sands and gravels are indicated when the counts per second (cps) are low (curve deflects to the left). Clays are indicated by higher cps (curve deflects to the right). Obtaining gamma logs in cased holes results in a slightly reduced amount of radiation that is measured at the probe, but has no effect on the interpretation of the logs unless multiple casing techniques are used to install the well, resulting in decreased readings as the tool enters each additional casing. No wells logged during this study have multiple casings

\section{Electro-magnetic conductivity logs}

Borehole EM logs measure the apparent conductivity (in millisiemens per meter $[\mathrm{mS} / \mathrm{m}$,$] ) or$ inversely, resistivity, (in ohm-meters) of formations in open holes or in wells with PVC casing, but cannot work in steel-cased wells. The EM logs in this report are displayed in units of conductivity. The EM log works in air or fluid-filled holes, and can be interpreted similarly to electrical resistivity logs that can only be run in open (uncased) boreholes. The EM logs in the Appendix are graphed with increasing values to the right, and the curve generally follows the same trend as the gamma log. Ground water with conductive contaminant plumes can be indicated when there is a significant increase in conductivity without a corresponding increase in cps on the gamma log.

Conductive metals near the well casing will cause the measurements to be anomalously high. Metal surface casings that protect each well from damage cause interference by increasing the measured conductivity as the EM tool approaches land surface. Other metal in the borehole or well will also cause anomalously high readings. Casing centralizers, made from metal, or rubber with metal clamps, will cause interference in the log. This type of interference was found on the following logs:

\section{DM110D MW10 MW11 MW12 MW19 MW20.}

Interference with metal was also found at the bottom of 11 wells. Measured EM conductivi $y$ increased on the logs in the bottom of these wells with no corresponding increase in specific conductance in water samples taken from the deeper screened interval, compared to the measured specific conductance in the corresponding shallower well. There were also no corresponding changes in lithology when the EM logs were compared to the gamma logs. The interference was most likely caused by the use of a "knock-out" plug in the bottom of the auger bit that kept drill cuttings from entering the auger flights during drilling. When the wells were installed inside the auger flights, the well casing pushed out the knock-out plug, leaving the plug in the hole and allowing the well to stay in position as the auger flights were removed. No records have been found to document what type of plugs--if any--were used. Logs from the following wells had an increase in conductivity values at the bottom of the well that did not correspond to any lithologic or waterquality changes: 


$\begin{array}{lllll}\text { DM110D } & \text { DM117D } & \text { DM118D } & \text { MW10 } & \text { MW11 } \\ \text { MW20D } & \text { MW43D } & \text { MW44D } & \text { MW206D } & \text { MW226D }\end{array}$

MW227D.

The gamma tool typically measures about $1.5 \mathrm{ft}$ deeper than the EM tool because the measuring point of the gamma tool is about $0.5 \mathrm{ft}$ above the bottom of the tool, whereas the measuring point of the EM tool is about $2 \mathrm{ft}$ above the bottom of the tool.

\section{Down-hole camera logs}

In May 1996, 55 wells in the study area were inspected with a Laval down-hole camera system as part of a larger basewide long-term monitoring project by the USGS. Twenty-nine wells outside this study area, but on base property, also were inspected with the downhole camera. Two different cameras were used: (1) a camera that would fit down a minimum 2-in.-diameter well casing, and (2) a larger camera that could fit down a minimum 4-in.-diameter casing. The aperture and focus of the larger camera could be changed downhole during logging, while the aperture and focus of the smaller camera was fixed while in the well. The intensity of the light source was adjustable for both cameras during logging. Wells in the study area that were logged with the down-hole camera are noted on table 1. The videotapes of the well logging are on file at the Dover, Delaware office of the USGS.

Of the 55 wells inspected, the only well that exhibited any sign of damage was DM110D, which had a crack at a casing joint at a depth of $4 \mathrm{ft}$ below the top of the steel protective casing, and just below land surface. There was no indication of any leakage into the well at the crack, and the crack is likely sealed by the concrete pad surrounding the well.

\section{WATER-QUALITY DATA}

Between July 1995 and August 1996, ground- and surface-water samples were collected in the study area to help determine if natural attenuation of contaminants is occurring. The following sections describe the field methods used to collect the samples, and the field methods used to determine concentrations of specific parameters. Ground- and surface-water quality samples collected during the July-August, 1995 and May-July, 1996 samplings were sent to a laboratory certified by the U.S. Environmental Protection Agency contract laboratory program (CLP). Field parameters, samples collected for methane, ethane, and ethylene, and samples collected during August, 1996 were analyzed by USGS personnel. The data are summarized in tables 5-9 at the end of the report.

\section{Ground-Water Samples}

Ground-water samples were collected from 35 wells during July-August 1995, and from 37 wells in May and July 1996. Additionally, samples from 21 wells were collected in August 1996. The location of the wells and piezometers that were sampled are shown in figure 5: All samples were analyzed for inorganic constituents (major ions and metals) and organic contaminants. Selected wells were also sampled for dissolved inorganic carbon, methane, and hydrogen. Inorganic ground-water quality data are shown in table 5, and organic ground-water quality data are shown in table 6.

\section{Sampling Methods}

Ground-water samples obtained during July-August 1995 and May-July 1996 were collected using a submersible, stainless steel and Teflon, positive displacement pump with a Teflon discharge tube. Drain- 


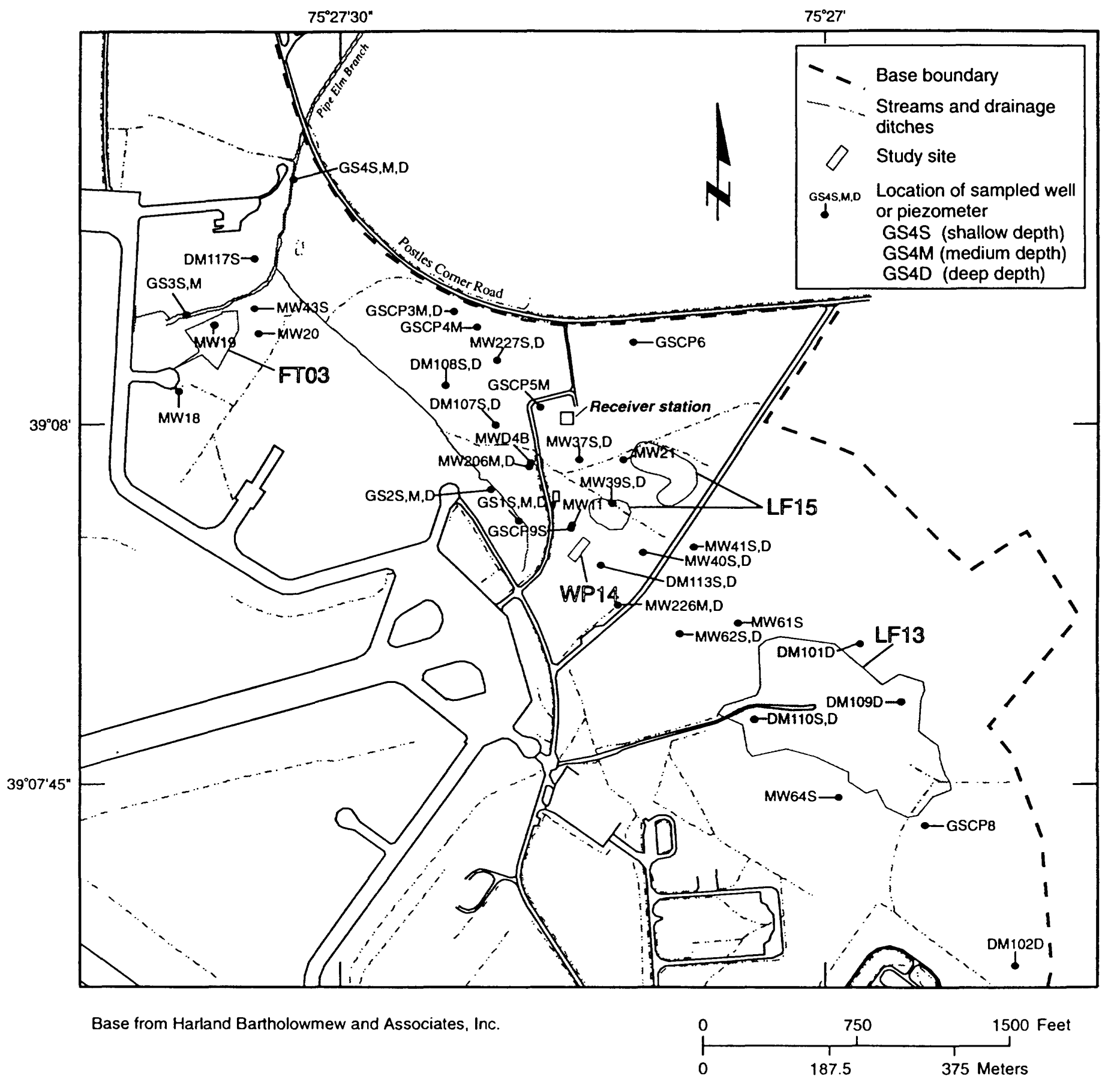

Figure 5. Locations of wells and piezometers sampled during July-August 1995, May-July 1996, and August 1996 at the natural-attenuation study area, Dover Air Force Base, Kent County, Delaware. 
age-ditch piezometers and DMI 10 S were sampled using a peristaltic pump with clear PVC laboratory grade tubing. The submersible pump was used for both purging and sampling each well. The pump was lowered to the top of the screened interval and the water was purged at a flow rate of 0.2 to $0.25 \mathrm{gal} / \mathrm{min}$ to prevent drawdown of the water column. Field parameters (specific conductance, dissolved oxygen, $\mathrm{pH}$, and temperature) were monitored in a flow-through chamber during purging. The wells were sampled after field parameters had stabilized, and at least one well volume had been purged.

Ground-water samples that were sent to the laboratory for inorganic analyses were filtered through a high capacity, 0.45 -micron in-line filter. Samples sent to the laboratory for volatile organic analyses were not filtered.

Alkalinity, dissolved iron $\left(\mathrm{Fe}^{+2}+\mathrm{Fe}^{+3}\right)$, and dissolved ferrous iron $\left(\mathrm{Fe}^{+2}\right)$ concentrations were determined in the field from filtered sample water. The alkalinity $\left(\right.$ as $\left.\mathrm{CaCO}_{3}\right)$ was determined using an incremental titration. The $\left(\mathrm{Fe}^{+2}+\mathrm{Fe}^{+3}\right)$ and $\mathrm{Fe}^{+2}$ concentrations were determined by the colorimetric bipyridine method (Brown and others, 1970, p. 103) using a portable Hach spectrophotometer.

Hydrogen sulfide was also determined in the field using the colorimetric bipyridine method, and concentrations were usually determined from unfiltered samples. In the 1995 sampling, when some water samples were too turbid to determine using the spectrophotometer, the samples were then filtered. In the 1996 sampling, no hydrogen sulfide samples were filtered. If the water was too turbid, then the hydrogen sulfide concentrations were not determined.

Ground-water samples collected during August 1996 were analyzed using different methods to determine hydrogen, methane, sulfide and dissolved inorganic carbon (DIC) concentrations, and field parameters. Methods for collecting those samples are described below.

Hydrogen $\left(\mathrm{as}_{2}\right.$ ) samples were collected by the bubble-strip method of Chapelle and McMahon (1991). A stream of water was pumped from the well through a gas-sampling bulb at a rate of about 600 milliliters per minute. An injected bubble of nitrogen in the bulb asymptotically collected hydrogen and other slightly soluble gases until equilibrium was achieved. Once equilibrium was achieved, (less than 5 percent change in 5 minutes, which occurred within 15 minutes), gas was extracted from the bulb with a syringe. Concentrations of $\mathrm{H}_{2}$ were measured with a gas chromatograph equipped with a Reduction Gas Detector (Trace Analytical, Menlo Park, California). $\mathrm{H}_{2}$ was separated from carbon monoxide and methane on a $0.5-\mathrm{m}$ column Carbosieve II (Supelco, Inc.) column using nitrogen as the carrier gas. The detection limit for $\mathrm{H}_{2}$ in a gas phase using this method is approximately 0.01 microliters per liter.

All samples from August 1996 were collected using standard water-quality techniques (Skougstad and others, 1978; Wood, 1976). All August 1996 samples were collected with a Bennett compressed-gas powered piston-driven submersible pump. Unstable parameters such as $\mathrm{pH}$, DIC, dissolved oxygen, sulfide, and dissolved $\mathrm{H}_{2}$ were measured in the field at the time of sample collection. Dissolved oxygen and sulfide were determined using colorimetric procedures. Dissolved oxygen was determined by Winkler titration. Samples for the determination of $\mathrm{Fe}^{+2}$ were filtered through a 0.1 -micron pore-size filter, and determined using the Ferrozine method with a Hach Colorimeter (Stookey, 1970). Nitrate and sulfate were separated in the laboratory by anion-exchange chromatography and quantified by conductivity detection. Methane and DIC samples were collected by using a syringe with an attached 0.2 micron pore-size filter to inject 5 milliliters of water into separate, sealed, septated vials. Samples were refrigerated to minimize microbial activity. Methane and DIC concentrations were quantified by thermal conductivity detection gas chromatography. Dissolved methane concentrations were calculated by using Henry's Law coefficients (Stumm and Morgan, 1981). 


\section{Decontamination Methods}

The pump and discharge line were decontaminated between the sampling of each well to prevent cross contamination. The outside of the pump head and line were scrubbed with a scrub-brush in a solution of deionized (DI) water and non-phosphate detergent and rinsed with DI water. The inside of the pump head and line were decontaminated by cycling a solution of DI water and detergent through the entire system. The pump head was placed in a 5-liter glass graduated cylinder full of the detergent solution and operated while discharging into the same cylinder for approximately 3 minutes. A DI water rinse followed by operating the pump in a separate rinse cylinder until the remaining detergent was no longer evident in the discharge. A 3-liter volume of isopropyl alcohol was passed through the system by operating the pump in a glass cylinder containing the alcohol (the same cylinder which earlier contained detergent solution). A final rinse of approximately three gallons of organic free DI water was flushed through the system. With organic free blank DI water still in the line, the pump head was covered in ultra clean aluminum foil and the entire system (pump, line, reel, and discharge tube) was enclosed in a fresh plastic bag for transport to the next sample site.

\section{Surface-Water Samples}

Surface-water samples were collected from four sites where the drainage-ditch piezometers are located, and the site locations are shown in figure 6. All surface-water samples were analyzed for the same constituents as ground-water samples. Samples were taken during July-August 1995, and May-July 1996.

Samples for laboratory analysis and field analysis were collected with a peristaltic pump and dedicated clear PVC laboratory-grade tubing. One end of the tubing was placed near the middle of the stream or ditch at a depth of about half that of the stream, and the other end of the tubing discharged sample directly into the sample container. Streams or drainage ditches were generally less than $10 \mathrm{ft}$ wide, less than $1 \mathrm{ft}$ deep, and nearly stagnant or very slow moving. Field parameters were determined by placing meter probes directly into the stream or ditch. Decontamination procedures for the tubing used for surface-water samples were the same as the procedures described in the ground-water section. Inorganic surface-water quality data are shown along with the inorganic ground-water quality data in table 5. Organic surface-water quality data are shown along with the organic ground-water quality data in table 6.

\section{EVALUATION OF QUALITY-ASSURANCE DATA}

Assessment of the quality of the water-quality data is an important step in data interpretation. In this report, data quality is evaluated in relation to data measurement error shown by reproducibility and bias. The quality of data is acceptable when analyte concentrations are reasonably reproducible and unbiased.

Reproducibility of data measurements can be determined using duplicate and field-spiked ampules. Duplicate samples were used to estimate the relative percent difference (RPD) between two theoretically similar measurements, and were calculated as follows:

$$
\frac{|(\mathrm{C} 1-\mathrm{C} 2)|}{(\mathrm{C} 1+\mathrm{C} 2) / 2} \times 100=\text { relative percent difference, }
$$

where $\mathrm{Cl}$ is the concentration in the first sample, and $\mathrm{C} 2$ is the concentration in the duplicate sample. In this study, RPD values greater than 40 percent indicate data measurements of poor quality. 


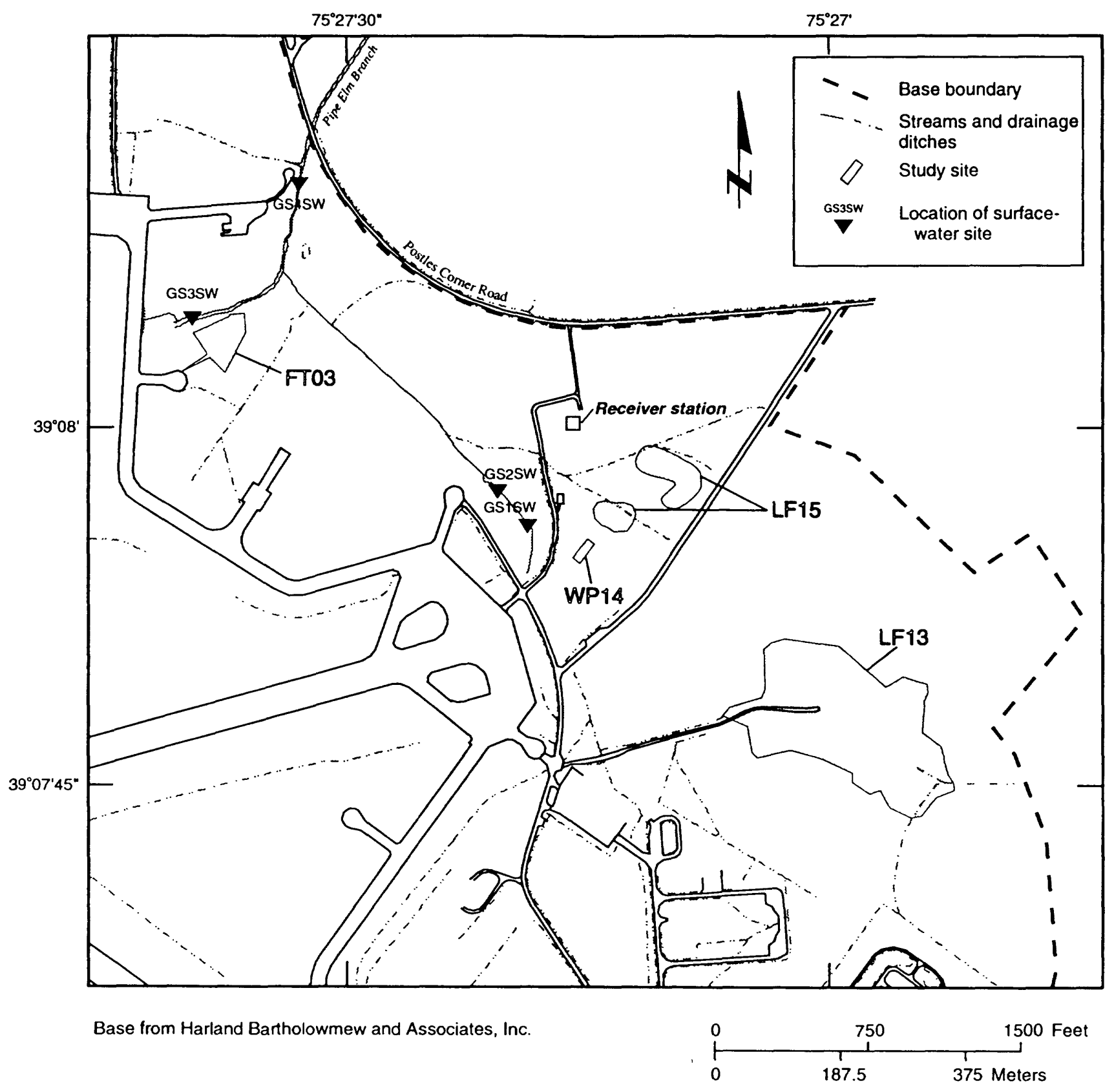

Figure 6. Locations of surface-water sites sampled during 1995 and 1996 at the natural-attenuation study area, Dover Air Force Base, Kent County, Delaware. 
Bias in data measurements can occur because of contamination from a variety of sources. Contamination may be introduced into water samples during the well installation, during the collection of samples, in transit from the field to the laboratory, and during analysis in the laboratory. A positive bias can be introduced in the measurement of one or more analytes as a result of contamination. Contamination bias can be assessed by the incorporation of blank samples into the sampling program. Sample water for the blanks in this study was organic-free de-ionized water that was commercially supplied.

Equipment blanks were used to assess equipment or sampling conditions that may result in sample contamination. Equipment blanks consisted of organic-free de-ionized water passed through sampling equipment which had been decontaminated in the field. Analysis of both inorganic and organic analytes were completed for these blanks.

Trip and ambient blanks were used to assess contamination of VOCs during the field collection and shipping process. Trip blanks were prepared by filling VOCs vials with organic-free de-ionized water, sealing the vials, and exposing the closed vials to field conditions, and then shipping the blanks to the laboratory for analysis of VOCs. Ambient blanks were prepared by exposing organic-free de-ionized water to ambient conditions at selected field sites, pouring the blank water into VOCs vials, and shipping to the laboratory for analysis of VOCs.

Contamination bias also can be determined by comparing the concentration of selected analytes to those in previous samples. Cross-contamination of samples is likely if samples with high concentrations of one or more analytes are chronologically followed by a series of samples that indicate a progressive decline in concentrations for those same analytes. In this study, checks on chronological analyses (date and time of collection) were used to determine if cross-contamination had occurred.

The quality-control samples shown in the following table were collected from ground- and surface-water sites during 1995-96. Data results for all constituents are listed in tables 5 and 6 of this report.

\begin{tabular}{|c|c|c|c|c|c|}
\hline \multirow{3}{*}{$\begin{array}{l}\text { Site } \\
\text { type }\end{array}$} & \multirow[t]{3}{*}{ Analyte group } & \multirow{3}{*}{$\begin{array}{c}\text { Duplicate } \\
\text { pairs }\end{array}$} & \multicolumn{3}{|c|}{ Blanks } \\
\hline & & & \multirow[t]{2}{*}{ Equipment } & \multicolumn{2}{|c|}{ VOCs } \\
\hline & & & & Trip & Ambient \\
\hline Ground & Organics & & & & \\
\hline \multirow[t]{6}{*}{ water } & VOCs & 7 & 15 & 8 & 2 \\
\hline & Methane & 17 & -- & -- & - \\
\hline & Inorganics & & & & \\
\hline & Major ions and & & & & \\
\hline & metais & 7 & 15 & -- & -- \\
\hline & Hydrogen & 15 & -- & -- & -- \\
\hline Surface & Organics & & & & \\
\hline \multirow[t]{6}{*}{ water } & VOCs & 2 & 2 & -- & -- \\
\hline & Methane & 2 & -- & -- & -- \\
\hline & Inorganics & & & & \\
\hline & Major ions and & & & & \\
\hline & metals & 2 & 2 & -- & - \\
\hline & Hydrogen & -- & -- & -- & -- \\
\hline
\end{tabular}




\section{Organic Analytes}

\section{Volatile Organic Compounds}

Analyte measurements were generally reproducible for the VOCs. Estimates of measurement reproducibility for these analytes were limited because the duplicate sample pairs seldom contained measurable concentrations. Ground water from four wells and surface water from one site had measurements above the reporting limit. The RPD of a VOC measurement varies as little as 0 percent and up to 11 percent. The four VOC compounds detected in these samples are shown in Table 7.

The sites at which duplicate samples were measured reflect the reproducibility of data measurements only for those sites with low concentrations of VOCs; duplicate samples were not representative of those environmental sites with higher concentrations of VOCs. For example, 60 of 82 environmental samples analyzed for trichloroethene had concentrations less than $1.0 \mu \mathrm{g} / \mathrm{L}$ (table 6); but data for the other 22 environmental samples ranged from $1.0 \mu \mathrm{g} / \mathrm{L}$ to $190 \mu \mathrm{g} / \mathrm{L}$. The median concentration for the 22 environmental samples was $30 \mu \mathrm{g} / \mathrm{L}$.

VOC concentrations in blanks rarely exceeded the reporting limits. Concentrations measured in blanks collected with the submersible pump were less than $2.0 \mu \mathrm{g} / \mathrm{L}$ for vinyl chloride and less than 1.0 $\mu \mathrm{g} / \mathrm{L}$ for other VOCs. However, concentrations above the reporting limits were measured in a blank collected with the peristaltic pump, equipment blank no. 16. The tubing used to collect this blank was discarded. The sequential data for samples collected for well DMI10S, equipment blank no. 16, and equipment blank no. 17 are shown in the following table.

\begin{tabular}{lccccc}
\hline \multicolumn{1}{c}{ Sample } & Date & Pump type & $\begin{array}{c}\text { cis-1,2- } \\
\text { Dichloro- } \\
\text { ethene, } \\
(\mu \mathrm{g} / \mathrm{L})\end{array}$ & $\begin{array}{c}\text { Chloro- } \\
\text { benzene, } \\
(\mu \mathrm{g} / \mathrm{L})\end{array}$ & $\begin{array}{c}\text { Vinyl } \\
\text { chloride, } \\
(\mu \mathrm{g} / \mathrm{L})\end{array}$ \\
\hline $\begin{array}{l}\text { DM110S } \\
\begin{array}{l}\text { Equipment } \\
\text { Blank No. } 16\end{array}\end{array}$ & $6 / 13 / 96$ & Peristaltic & 1,400 & 61 & 800 \\
$\begin{array}{l}\text { Equipment } \\
\text { Blank No. } 17\end{array}$ & $6 / 14 / 96$ & Peristaltic & 24 & 2.4 & 4.7 \\
\hline
\end{tabular}

Blank data indicate that there is no cross-contamination of VOCs during sampling. Evidence shows that the VOCs detected in equipment blank no. 16 was not transferred to subsequent environmental samples.

\section{Methane}

Analyte measurements were reproducible for a wide range of concentrations of methane. Estimates of measurement reproducibility for methane included data from 17 duplicate samples (table 8). The median relative percent difference (RPD) for the duplicate samples was about 5 percent and ranged from 1 percent to 17 percent. Concentrations ranged from about $30 \mu \mathrm{g} / \mathrm{L}$ to about $11,000 \mu \mathrm{g} / \mathrm{L}$; and the RPD for those samples was 7 percent and 5 percent, respectively. 


\section{Inorganic Analytes}

\section{Major Ions and Metals}

The major ions of dissolved calcium, magnesium, sodium, potassium, chloride, sulfate, nitrogen and phosphorus are in this analyte group. The metals include dissolved aluminum, antimony, arsenic, barium, cadmium, chromium, cobalt, iron (total and $\mathrm{Fe}^{2+}$ ), lead, manganese, mercury, molybdenum, nickel, selenium, silver, thallium, vanadium, and zinc.

Analyte measurements were generally reproducible for the major ions and metals. Estimates of measurement reproducibility for these analytes were limited because the duplicate sample pairs often contained concentrations below the reporting limit for the constituent. A summary of measurement reproducibility for the 10 analytes in this group that had at least one duplicate pair with measurements above the reporting limit is shown in the following table.

\begin{tabular}{lcccc}
\hline Analyte & $\begin{array}{c}\text { Number of } \\
\text { duplicate } \\
\text { pairs, all }\end{array}$ & $\begin{array}{c}\text { Number of } \\
\text { duplicate pairs } \\
\text { less than } \\
\text { reporting limit }\end{array}$ & Relative percent difference \\
\cline { 5 - 5 } Calcium & 9 & 1 & 1 & Minimum \\
Magnesium & 9 & 2 & 2 & 1 \\
Sodium & 9 & 9 & 7 & 1 \\
Potassium & 9 & 1 & 0 & 1 \\
Chloride & 9 & 9 & 2 & 0 \\
Sulfate & 9 & 9 & 2 & 0 \\
Nitrogen, ammonia, as N & 9 & 1 & 0 & 1 \\
Nitrate, as N & 9 & 2 & 1 & 0 \\
Iron (total) & 9 & 5 & 12 & 0 \\
Manganese & 9 & 6 & 11 & 0 \\
Zinc & 9 & 7 & 35 & 3 \\
\hline
\end{tabular}

The RPDs ranged from 0 percent for zinc to 35 percent for several analytes. The RPD was greater than 10 percent for some samples with low concentrations. Zinc measured in duplicate samples ranged only from less than the reporting limit of $0.010 \mathrm{mg} / \mathrm{L}$ to $0.036 \mathrm{mg} / \mathrm{L}$. The RPD for zinc ranged from 3 percent to 35 percent. Concentrations for iron at one surface-water site, GS4SW, were $0.24 \mathrm{mg} / \mathrm{L}$ and 0.27 $\mathrm{mg} / \mathrm{L}$ and the RPD was 12 percent. In other duplicate samples, the concentration of iron ranged from 0.19 $\mathrm{mg} / \mathrm{L}$ to $19 \mathrm{mg} / \mathrm{L}$ and the RPD for these samples ranged from 2 percent to 8 percent.

Concentrations of the major ions and metals in blanks only exceeded the reporting limits for a single analyte in 2 of 17 blanks. Chloride concentrations from equipment blanks nos. 5 and 16 were 0.62 and $0.53 \mathrm{mg} / \mathrm{L}$, respectively. All other measurements were less than the reporting limit of $0.50 \mathrm{mg} / \mathrm{L}$. 


\section{Hydrogen}

Analyte measurements were generally reproducible for a wide range of hydrogen concentrations. Concentrations ranged from about less than 1.0 nanomoles/L to 21 nanomoles/L (table 9 ). Estimates of measurement reproducibility for hydrogen included data from 17 duplicate samples. The median RPD for the duplicate samples was about 9 percent and ranged from 2 percent to 37 percent.

\section{Field Measurements}

Equipment blanks were not collected for measurement of specific conductance, $\mathrm{pH}$, alkalinity, water temperature, dissolved oxygen, dissolved iron, and hydrogen sulfide. Replicate measurements of sample water were usually completed for two species of dissolved iron (total and $\mathrm{Fe}^{2+}$ ) and hydrogen sulfide; differences in the replicates was always less than 50 percent (data not shown). Dissolved-oxygen concentrations were determined by meter, but concentrations less than $0.5 \mathrm{mg} / \mathrm{L}$ were also determined by Winkler titration.

\section{Summary of Quality-Assurance Data Evaluation}

The following conclusion is based on an examination of the quality of ground- and surface-water data collected for this study: Data for volatile organic carbon compounds, methane, major ions, metals, and hydrogen are of good quality. All RPD values were less than 40 percent. The RPD ranged from 0 percent to 11 percent for VOC compounds, 1 percent to 17 percent for methane, 0 percent to 35 percent for major ions and metals, and from 2 percent to 37 percent for hydrogen.

There was no evidence of cross-contamination in any samples and the data were reproducible and unbiased. 


\section{SELECTED REFERENCES}

Brown, Eugene, Skougstad, M.W., and Fishman, M.J., 1970, Methods for collection and analysis of water samples for dissolved minerals and gases: Techniques of Water-Resources Investigations of the U.S. Geological Survey, Book 5, Chapter A1, 160p.

Chapelle, F.H., and McMahon, P.B., 1991, Geochemistry of dissolved inorganic carbon in a coastal plain aquifer: 1. Sulfate from confining beds as an oxidant in microbial $\mathrm{CO}_{2}$ production, in Journal of Hydrology, 127:85-108

Dames and Moore, 1994, Area 6 Remedial investigation, Dover Air Force Base, Dover, Delaware, July, 1994: Prepared for the U.S. Department of the Air Force, Dover Air Force Base, 436 SPTF/CEV, v. I-IV, 610 p., plus 4 appendices.

Dames and Moore, in press (a), Remedial investigation, east and north management units, Dover Air Force Base, Dover, Delaware, Volumes I and II [variously paged]

, in press (b), West management unit, remedial investigation, Dover Air Force Base, Dover, Delaware, Volumes I and II [variously paged]

Haeni F.P., 1986, The use of electromagnetic methods to delineate vertical and lateral lithologic changes in glacial aquifers: Proceedings of the Conference on Surface and Borehole Geophysical Methods and Ground Water Instrumentation, by The National Water Well Association, Denver, Co., October $15-17,1986,26 \mathrm{p}$.

Hazardous Waste Remedial Actions Program (HAZWRAP), 1990, Installation restoration program, draft technical memorandum: Sampling and data results, sites T-01, SP-9, D-4, and DD-1, Dover Air Force Base, Delaware, submitted by E.C. Jordan and C.C. Johnson and Malhotra, February, 1990.

Johnston, Richard H., 1973 Hydrology of the Columbia (Pleistocene) deposits of Delaware: An appraisal of a regional water-table aquifer: Delaware Geological Survey, Bulletin No. 14, 78 p.,

Leahy, Patrick P., 1976, Hydraulic characteristics of the Piney Point aquifer and overlying confining bed near Dover, Delaware: Delaware Geological Survey Report of Investigations No. 26, 24p.

1982, Ground-water resources of the Piney Point and Cheswold aquifers in central Delaware as determined by a flow model: Delaware Geological Survey, Bulletin No. 16, 68 p.

Science Applications International Corporation (SAIC), 1986, United States Air Force installation restoration program--Dover Air Force Base, Delaware, Phase 11--Stage 1 confirmation/quantification. 1989, Installation restoration program-stage 2 draft final report, Dover Air Force Base, Delaware.

Skougstad, M.W., Fishman, M.J., Friedman, L.C., Erdmann, D.E., and Duncan, S.S., 1978, Methods for analysis of inorganic substances in water and fluvial sediments: U.S. Geological Survey Open File Report 78-679, 159 p.

Stookey, L.L., 1970, FerroZine, a new spectrophotometric reagent for iron, in Analytical Chemistry, p. 779-781. 


\section{SELECTED REFERENCES--Continued}

Stumm, Werner, and Morgan, J.J., 1981, Aquatic Chemistry: John Wiley and Sons, New York, 780 p.

Sundstrum, R.W. and Pickett, T.E., 1968, The availability of ground water in Kent County, Delaware, with special reference to the Dover area, University of Delaware, Water Resources Center, Newark, Delaware, $123 \mathrm{p}$.

Vroblesky, D.A., and Chapelle, Francis H., 1994, Temporal and spatial changes of terminal electronaccepting processes in a petroleum hydrocarbon-contaminated aquifer and the significance for contaminant biodegradation, in Water Resources Research, American Geophysical Union, vol. 30, no. 5, pages 1561-1570, May 1994

Wood, W.W., 1976, Guidelines for collection and field analysis of ground-water samples for selected unstable constituents, in U.S. Geological Survey Techniques of Water-Resources Investigations, Book 1, Chapter D2, 24 p. 
Tables 1 through 9 follow 


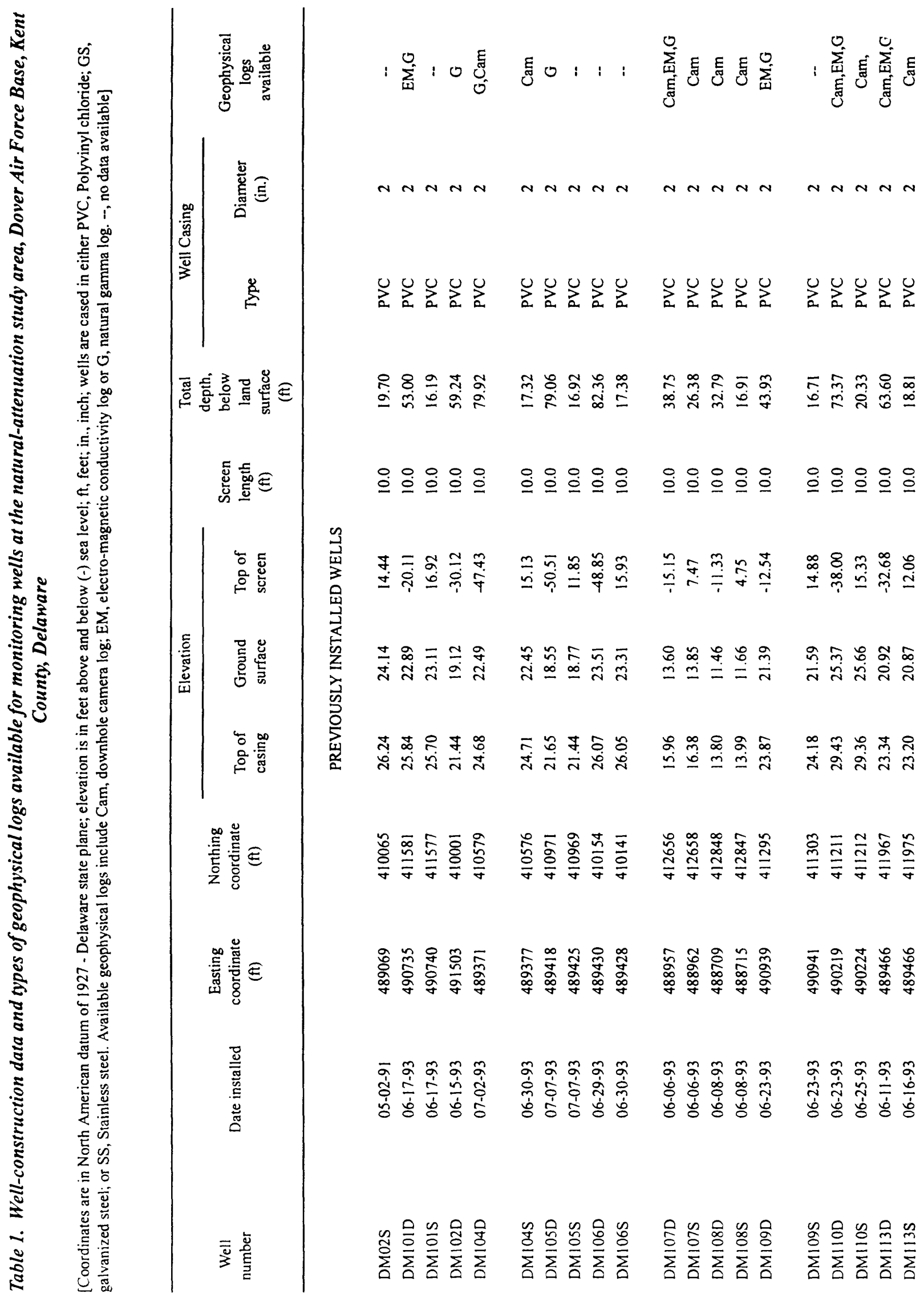




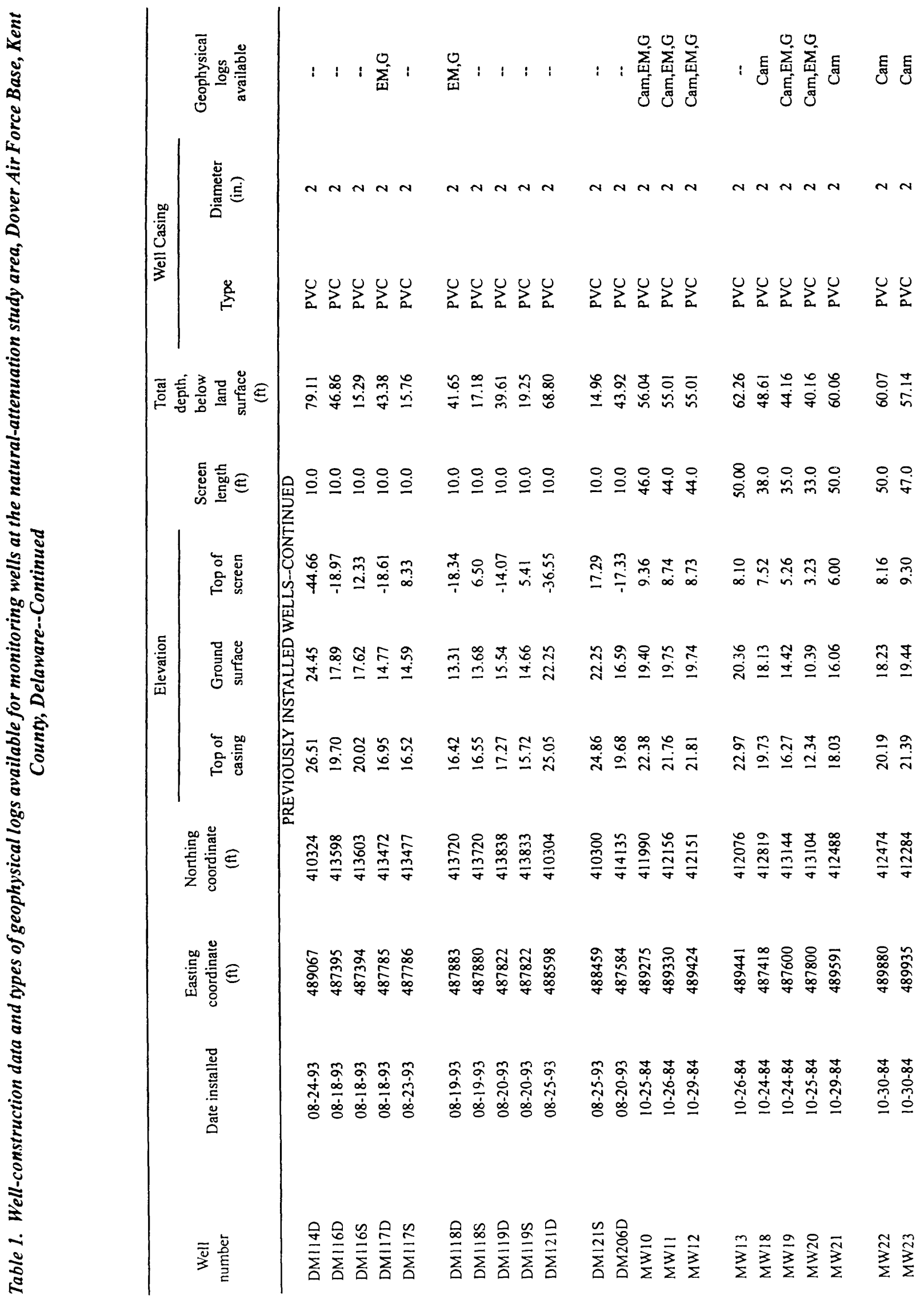




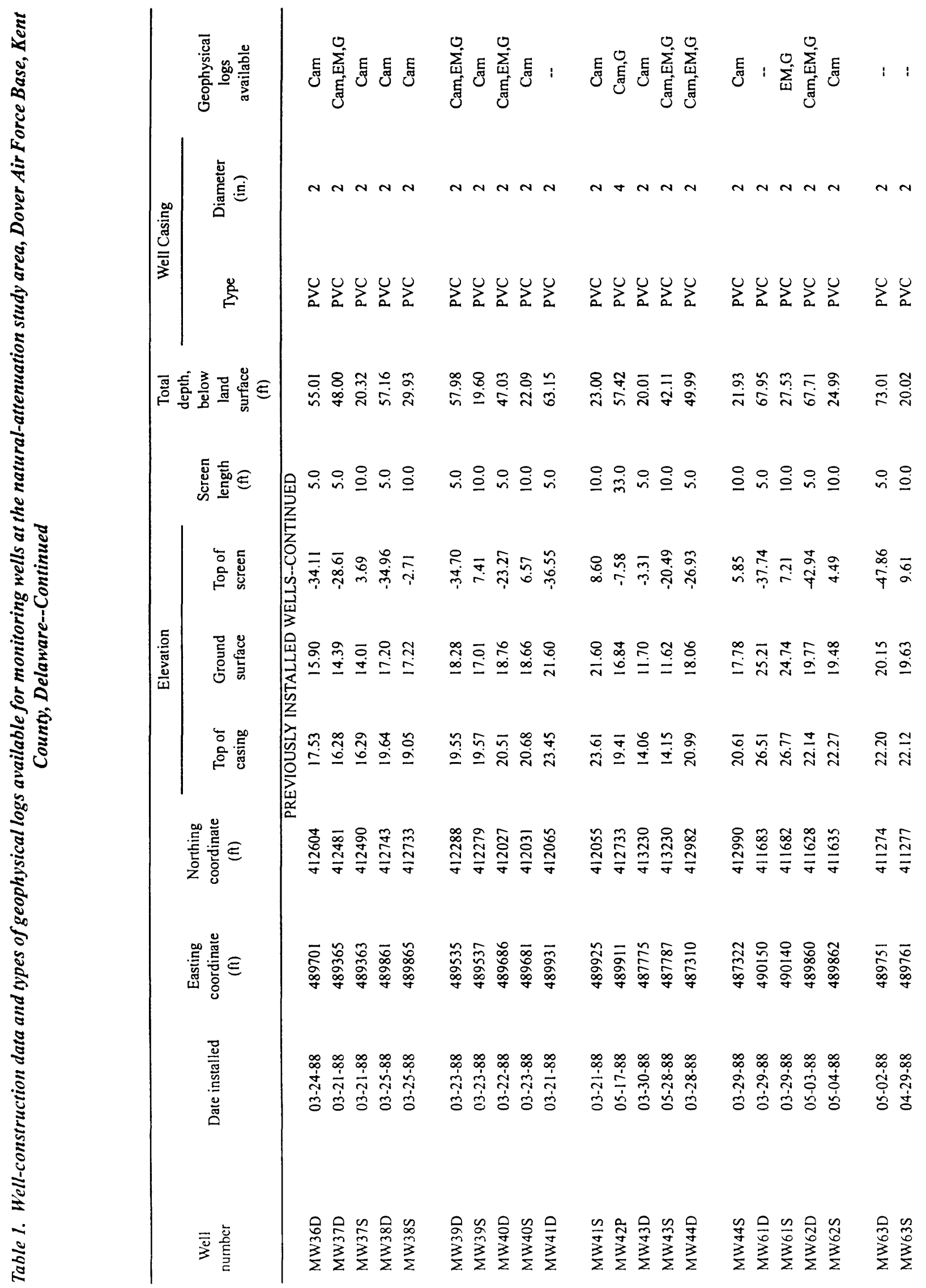




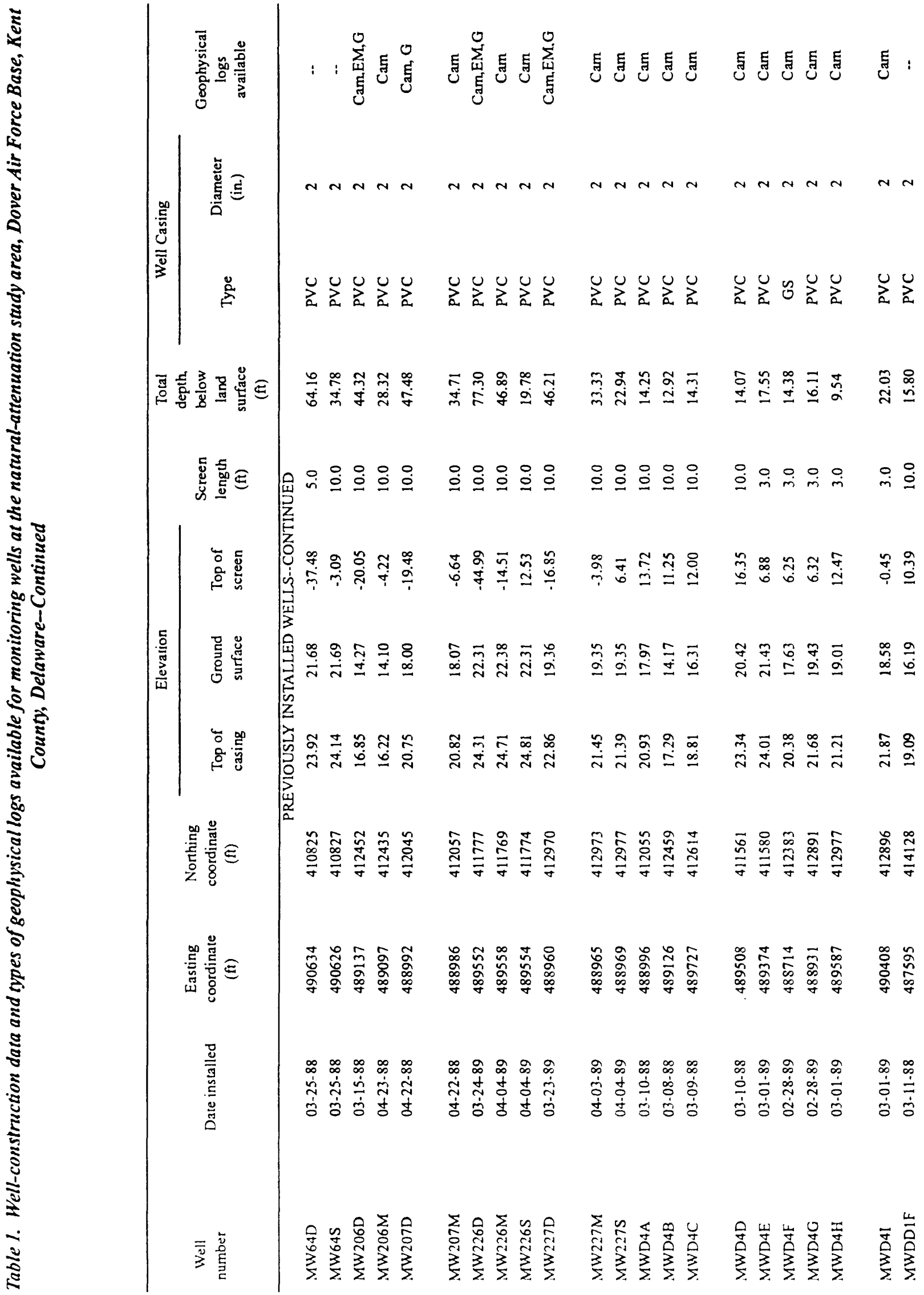




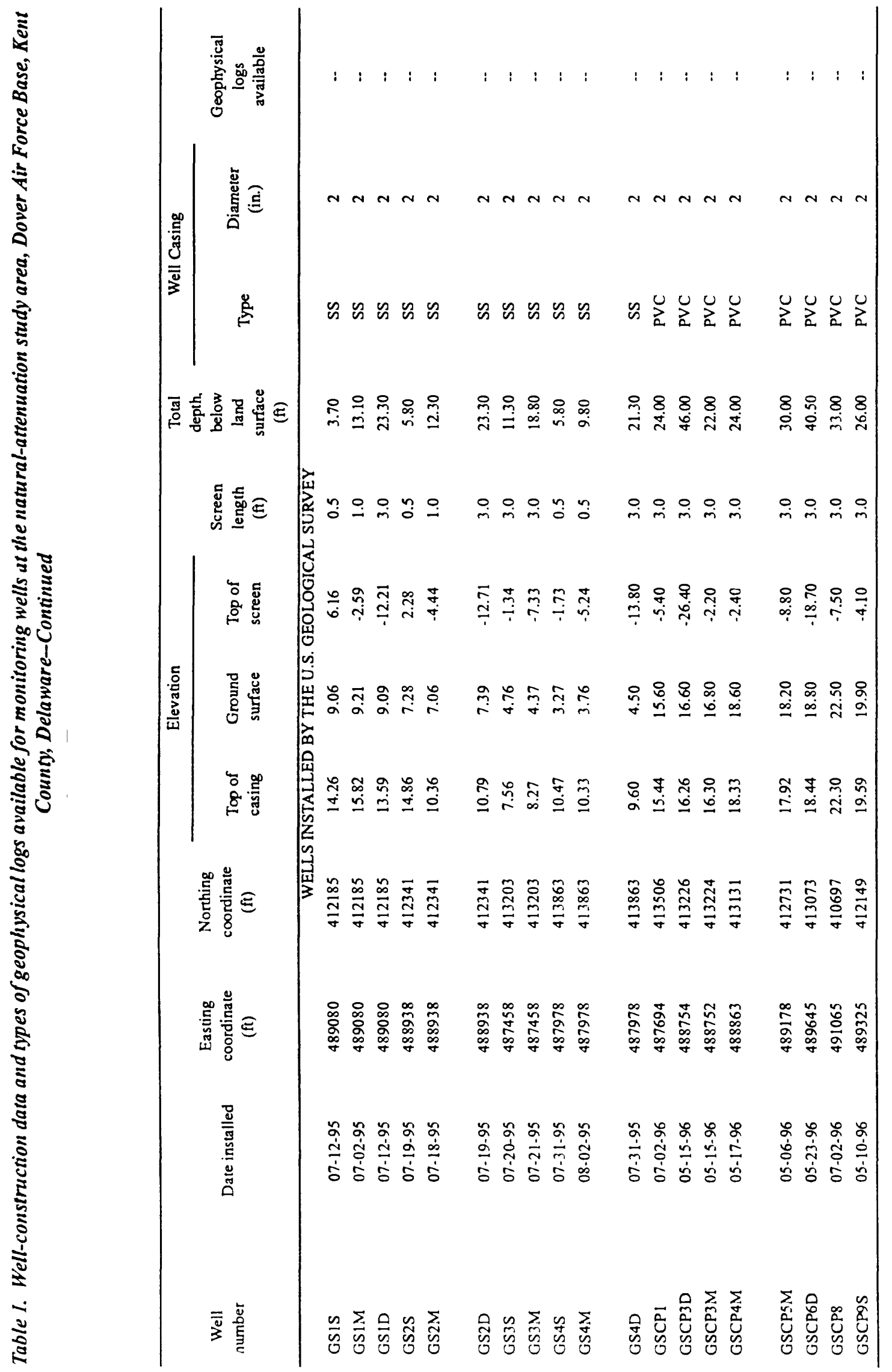




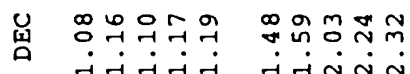

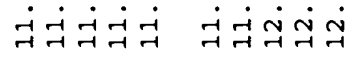

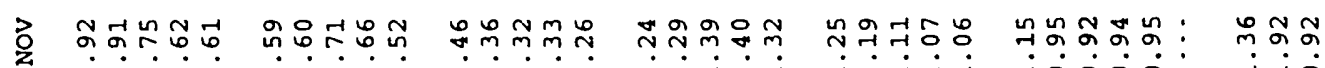
નંનંનં

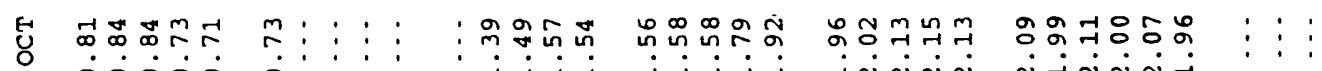

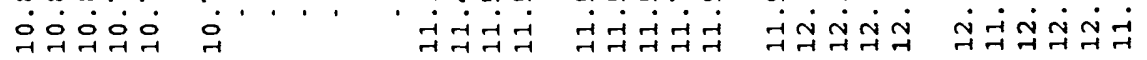

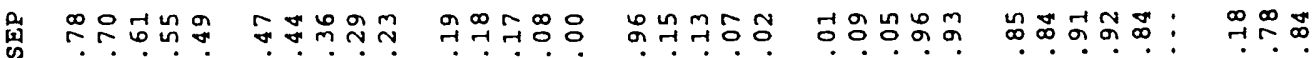

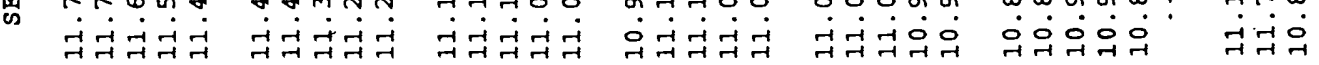

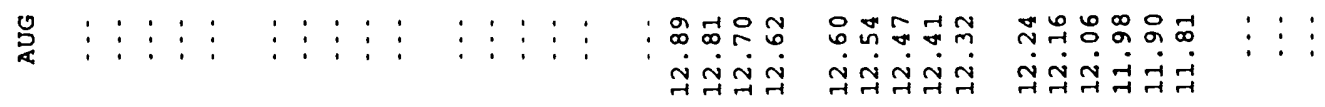

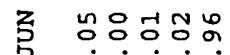

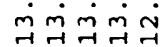

$\operatorname{lom}_{\infty}^{\infty} \underset{\infty}{n}$ in

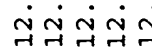

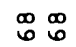
i

要

온ํㄱ웜

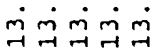

웡요 लं

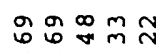
可远远远

ㅊำ궁 बुन्न

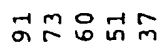

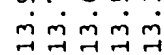

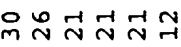

노옹 ํํำำำํำ

능동우웜

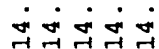
ind

운: ने

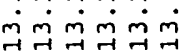

幽岑孚

㩊 $\vdots \vdots \vdots \vdots \vdots$ निम्निम

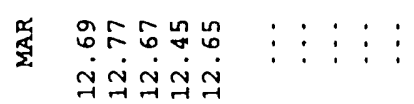

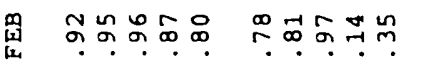

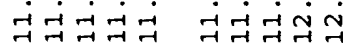

ดु

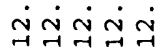

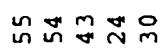

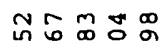

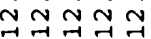

ज्नलंख्न

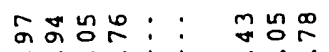
F.

䒺

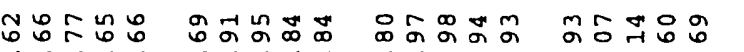
बनंबनं नं वंनं

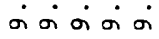
वंग्नं०्न

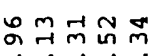

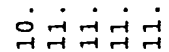

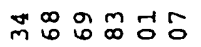
تं

ํㅜㅇํํำ

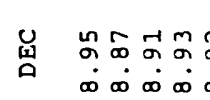

ผูกสู ตั 응

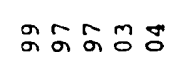

.

ธีำ

$m \infty a+\infty$

$\infty \infty \infty \dot{0} \infty$

$\infty \infty \infty$ o

नंनंबं

वंनंवंa

ำก음

旾

Oे

ํํำำ

on un in o 0

$\stackrel{\sim}{\sim} \stackrel{\infty}{\sim} \stackrel{\infty}{\sim} \underset{v}{*}$

ํำ ํำ

ํㅗㅇㅇㅛ $\infty \infty \infty \dot{\infty} \infty$ $\infty \infty_{\infty}^{\infty} \infty \dot{\infty}$ $\infty \dot{\infty} \dot{\infty} \dot{\infty}$ $\dot{\infty} \dot{\infty} \dot{\infty} \dot{\infty}$

ம

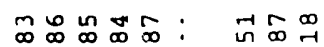
ty 希 TNm or $\infty$ a음

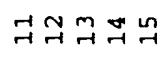
ํำำำ웅 กำ $\stackrel{ก}{\sim}$ N $\dot{\infty} \infty \dot{\infty} \dot{\infty} \infty$ 오N 


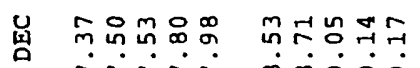

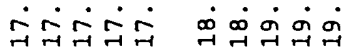

के

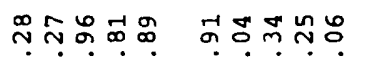

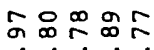

$\dot{0} \dot{0} \dot{0} \dot{0}$

또ํํำำกำ

구웅요요

중뉴

ภูกิ

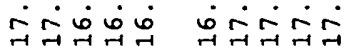

(1)

8

ํํำก ที่

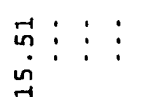

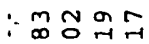

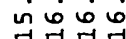

웅ำ

ம்0்

ํㅜㅇำํํㅇㅇำ

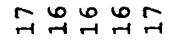

क्षें

过

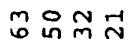

नित्नित्न

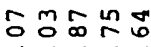

$\therefore \dot{0} \dot{0}$

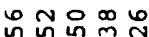

ஸें

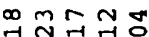

๑ं

웡ํำ

कों

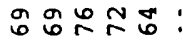

जी

705 年

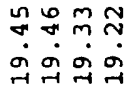

욱규요용

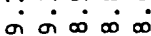

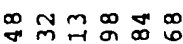

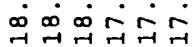

मे

포요

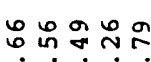

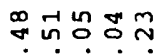

구웡

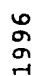

勇

โก

gं

ramra

r-jn:

는

o 0 an

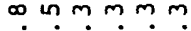

눙

न듣ㄷ

N

बंनंबं

Ho

ํํํํํํํㅇํㅇ

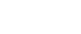

约

昆

\.

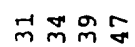
웡ㅇㅇ

oำ

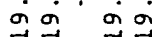

की $\begin{aligned} & 0 \\ & \text { की }\end{aligned}$

융요

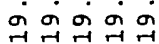

: กับั

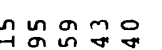

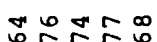

으으음

- and

กัด

0 ⿰纟勺 0 年

nn

तंกํํํํ

ํํํํํํ

수슉ำ

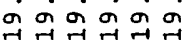

क्त

\section{喿}

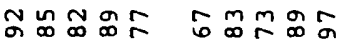

ar $2 \pi$

무ㅇㅠㅜ

더에

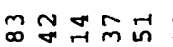

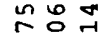
유유유 윳ㅇㅅ

웅ㅇㅇ

궁ㅇㅇㅇㅇ

웅ㅇㅇ

윳유

帘

꿔ำ

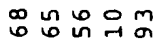

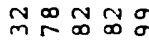

กิำ

$\infty \infty \pi N$

응 9 का 잉요

\%ă

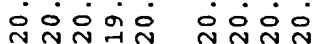

$\dot{\sim} \dot{\sim} \dot{\sim} \dot{N}$

웡ㅇㅇㅇ

ก

웟ㅇㅅ유웅

유요

思

*am $n$

แุ

눈

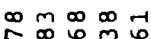

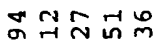

mำ ํํㅇ:

in थี

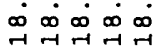

$\dot{\infty}_{\rightarrow \rightarrow 1}^{\infty} \dot{\sigma} \dot{\sigma} \dot{\sigma}$

बंनेंक

कं

बं 0 0

¿00:

बं $\dot{0}$

\section{孞}

$\infty \begin{aligned} & \infty \\ & 0 \\ & 0\end{aligned}$ in $n_{-1}^{n}$ in

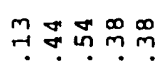

๓ ก थ

ช ษั

og $\begin{aligned} & \text { an } \\ & \text { m }\end{aligned}$ ?ִ

ตูำ원둥

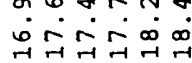

ตㄷำ nก $\operatorname{con}_{-1}^{n} n$

กำกษ

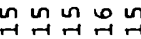

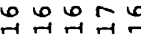

ก 0 m

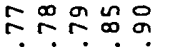

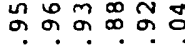

m

\section{高}

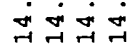

n
o
-

วิ

넝유 준

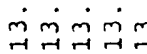

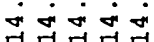

过苛市

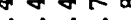

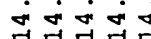

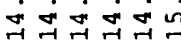

㲾出

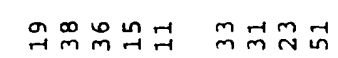

\section{मं}

m $m$ ?

융요융

윯

ㄷํㅇํㅇ:웅

mं $\dot{\nabla} \dot{\square}$

: ก

8 भी

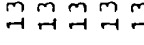

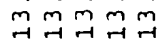

$\dot{m}_{\vec{r}} \dot{m}_{\vec{r}}^{\infty} \dot{m}_{\vec{r}}^{\infty}$

mit

궁의웡

$\operatorname{mim}_{\rightarrow \rightarrow-1} \dot{m} \dot{m} \dot{n}$

齐

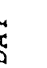

hnman ormad

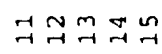

눋ำ

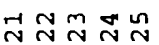

소요무

养着负 


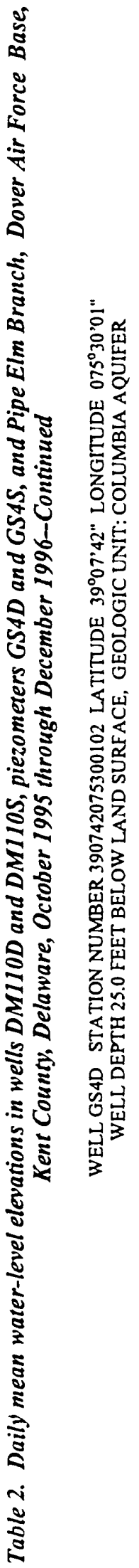

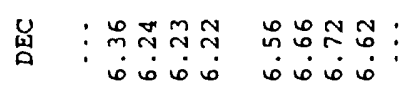

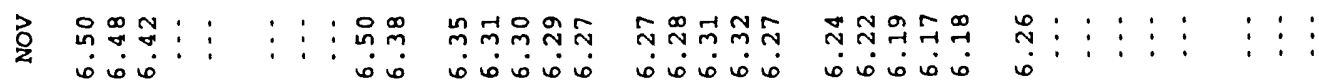

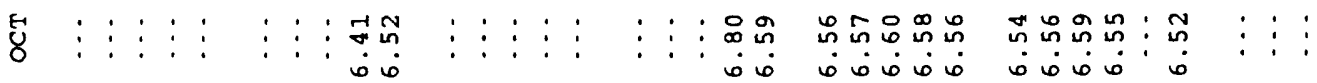

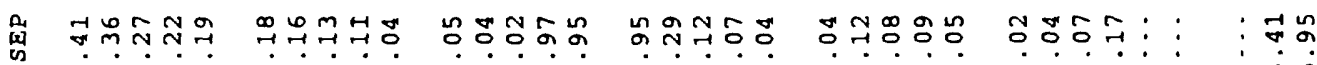

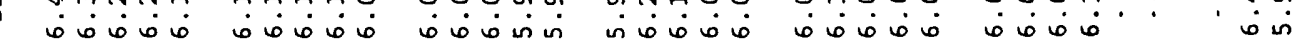

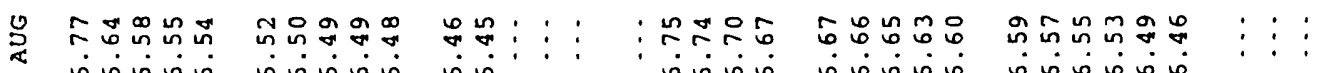

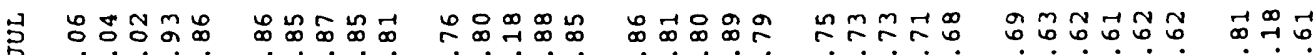
๙ू.

h

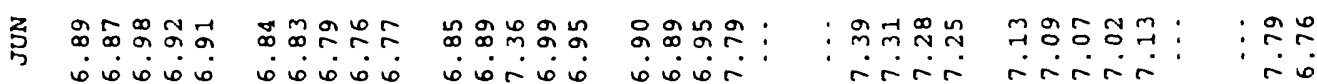

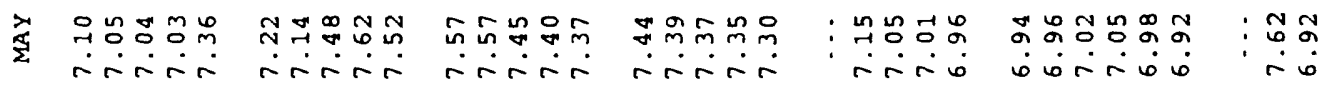

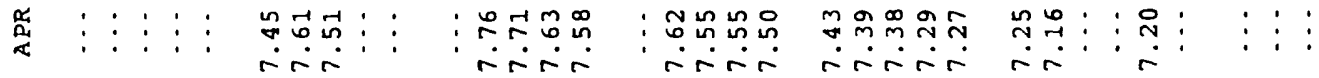

莡

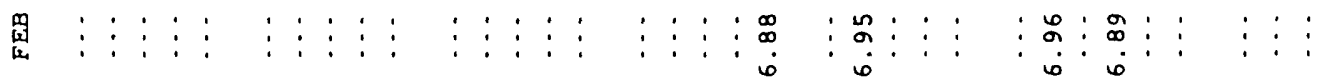

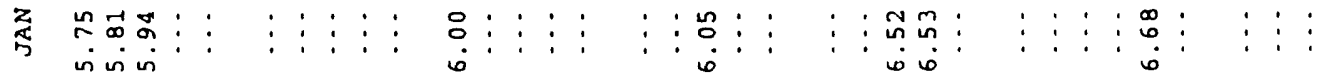

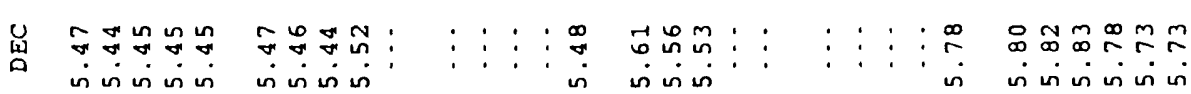

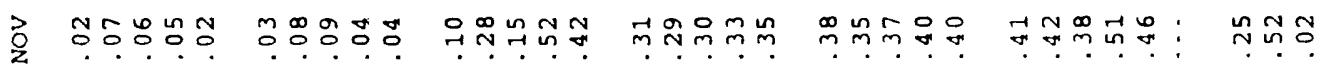
z में

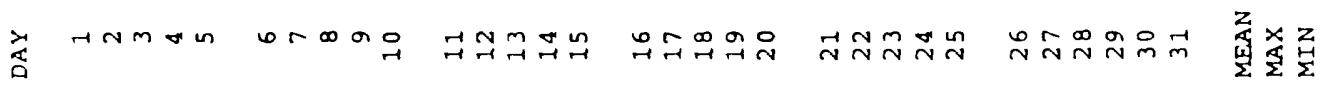




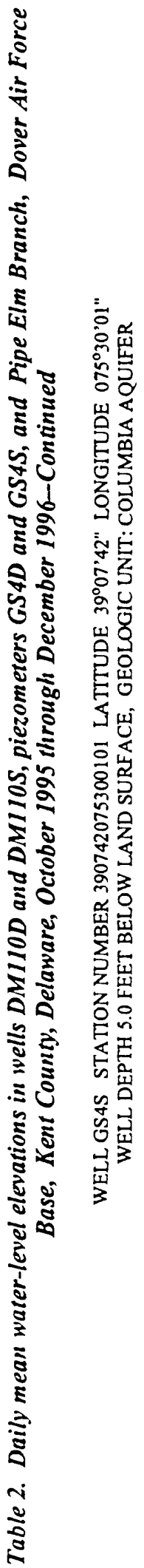

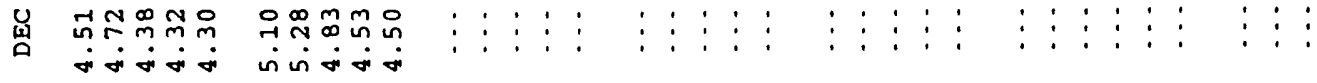

ర

대

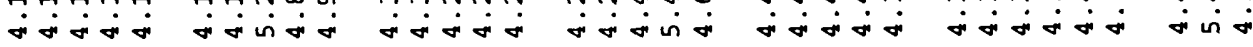

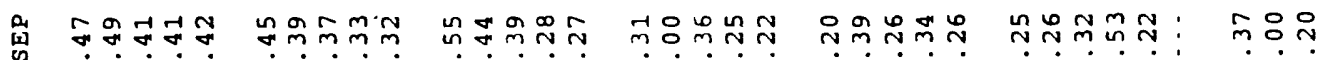

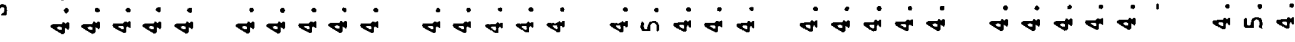

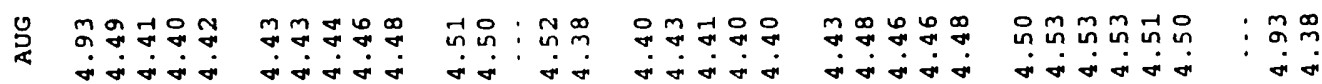

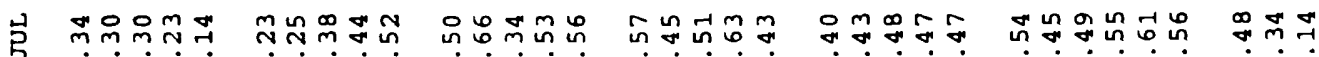
ڤั

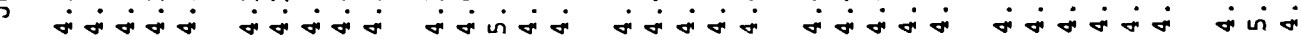

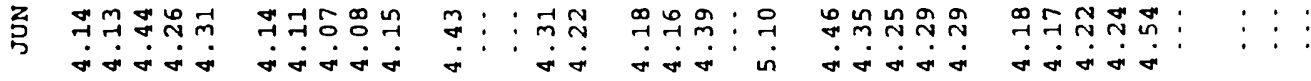

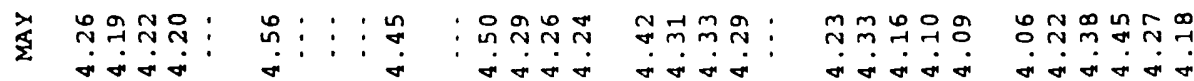

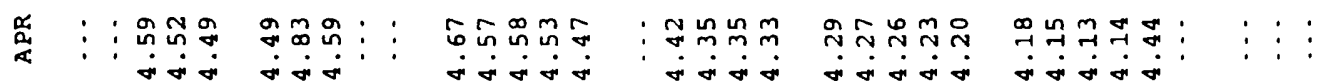

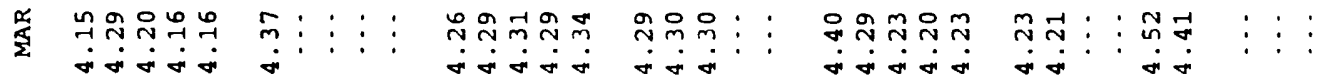

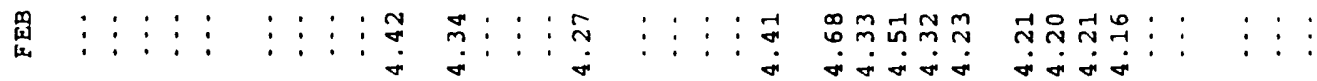

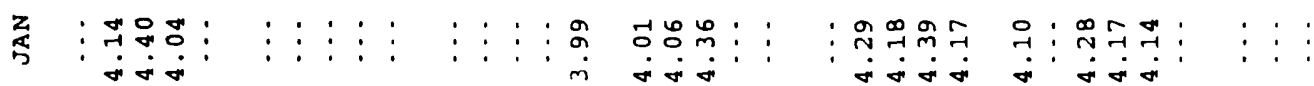

प्山

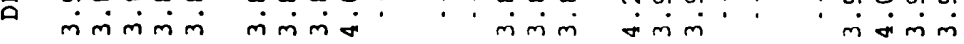

奋

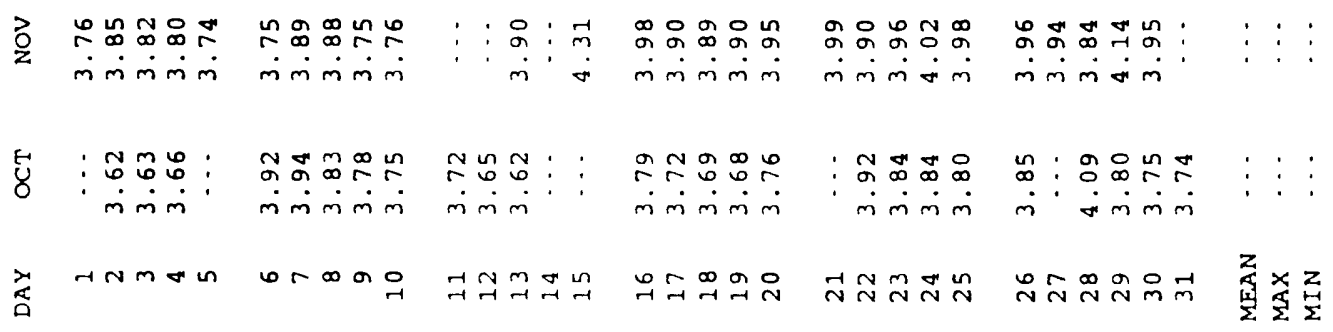




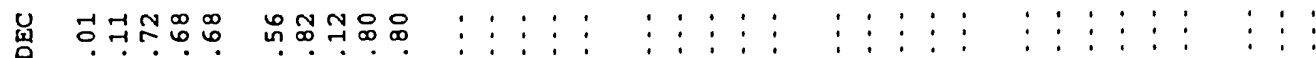

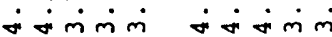

马े

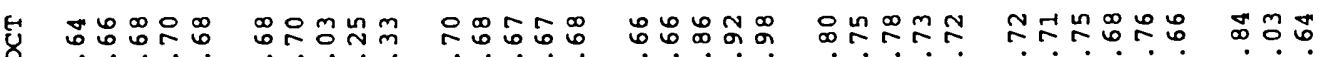

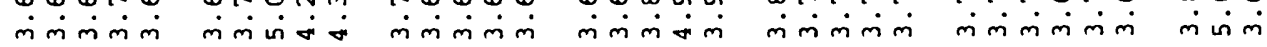

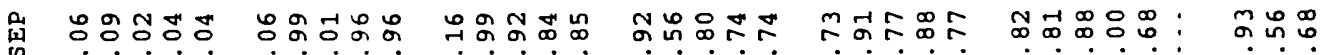

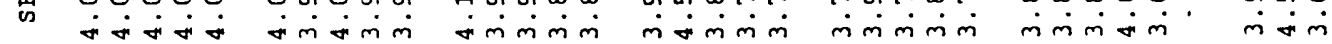

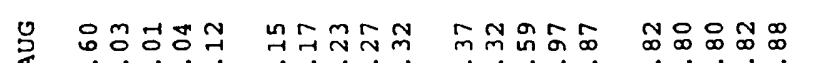

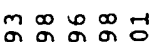

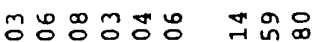

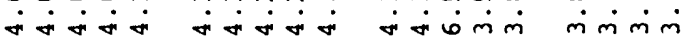

$\dot{m} \dot{m} \dot{m} \dot{m} \dot{0}$

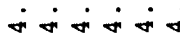

$\dot{\sigma} \dot{\dot{m}}$

官

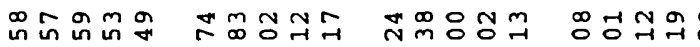

लिं

$\dot{m} \dot{m} \dot{\nabla} \dot{\sigma}$

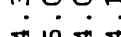

ํำ

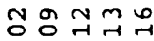

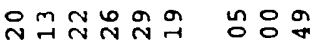

an $\infty$ r $\forall \rightarrow \infty$ in imंmin

幽务

$m \infty$
$\infty$$\underset{\infty}{m}$ in in

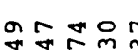

वं कर

$\dot{4} \dot{-} \dot{0}$

نं

兵

约

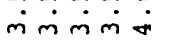

लिखण वर्ष

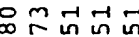

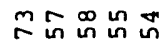

लंखिं $\dot{m} \dot{m}$

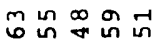

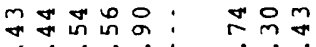
लिंकिष

लिंकिंल

लिंलिं

लंखि

茴

ำกำก

जिंगुल

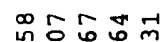

mmm mim

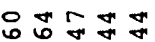

THF⿻응

옹요

लंखिंलें

लिं लंखिं

iे $\dot{x}$

$\sum$

लिखिं

โ็

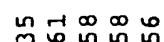

กูกูกิด

ก n

노용

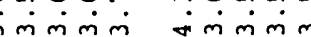

लिंलिलि

लिं $\dot{m} \dot{m} \dot{m}$

in $\sin$

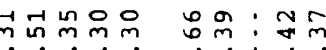

iिं $\dot{m} \dot{m}$

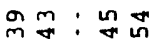

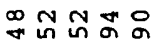

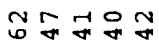

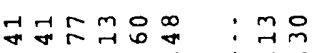

$m$ m m

$\dot{m} \dot{m} \dot{m} \dot{m}$

लिंलिंलि

लंmं்

$\dot{m} \dot{m} \dot{m} \dot{m}$

เां

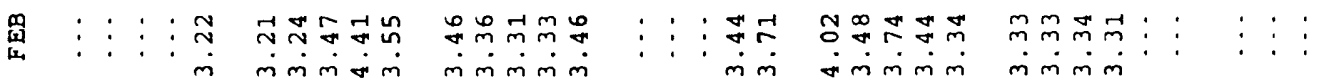

Z

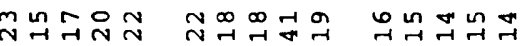

लिंलिंलि

लिंलिं

लिंmंधि

$\operatorname{mon}:$

$: \stackrel{\sim}{\sim} \underset{m}{\infty} \stackrel{\infty}{\sim} \underset{\sim}{\sim}$

लिंलें

लिं लिं

สำ

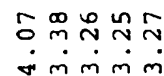

?

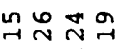

in $\pi$

mån:

고고ำ

लिंलिं

लिंलिल

लिंलिं

लिंकिल

윰점유

मिंmं

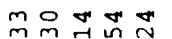

लिं लिं

$: 57$

m

국욱옹윢

ํㅡㅇ슈곡조

$\stackrel{\infty}{\infty}-\pi$

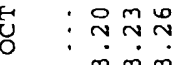

$\dot{m} \dot{m} \dot{m}$

लिंmं

लिंलि

जिंलिं

舟的

ำ응

춤

TNm

or $\infty$ or 0

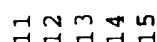

둥ㅇㅇ

$\underset{N}{ } \mathcal{N} \underset{N}{ }$

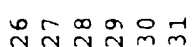

骨路 
Table 3. Measured ground-and surface-water level elevations at the natural-attenuation study area, Dover Air Force Base, Kent County, Delaware, July 1995 through September 1996

[ Locations of wells shown in figure 2; surface-water sites shown in figure 7; --, data not collected]

\begin{tabular}{|c|c|c|c|c|c|c|c|}
\hline \multirow{3}{*}{$\begin{array}{c}\text { Well } \\
\text { identification } \\
\text { number }\end{array}$} & \multicolumn{6}{|c|}{ WATER-LEVEL ELEVATIONS IN FEET ABOVE SEA LEVEL } & \\
\hline & \multicolumn{2}{|c|}{1995} & \multicolumn{5}{|c|}{1996} \\
\hline & July 24 & $\begin{array}{c}\text { December } \\
6\end{array}$ & March 6 & April 26 & June 4 & August 16 & $\begin{array}{c}\text { September } \\
19\end{array}$ \\
\hline \multicolumn{8}{|c|}{ GROUND'WATER LEVELS } \\
\hline DM101D & 8.99 & 8.86 & 12.70 & 13.72 & 12.84 & 12.79 & 10.92 \\
\hline DM101S & 14.96 & 13.25 & 21.13 & 21.05 & 20.26 & 18.04 & 15.91 \\
\hline DM107D & -- & -- & - & - & 10.21 & 9.87 & 8.78 \\
\hline DM107S & -- & - & - & - & 10.43 & 10.04 & 8.90 \\
\hline DM108D & -- & -- & - & - & 9.21 & 8.98 & 7.95 \\
\hline DM108S & -- & -- & - & - & 9.37 & 9.09 & 8.04 \\
\hline DM109D & 9.30 & 8.99 & 13.22 & 14.32 & 13.35 & 13.5 & 11.22 \\
\hline DM109S & 13.83 & 11.68 & 20.67 & 20.68 & 19.8 & 17.73 & 14.98 \\
\hline DM110D & 9.12 & 8.88 & 12.75 & 13.83 & 12.95 & 12.9 & 11.01 \\
\hline DM110S & 15.04 & 14.16 & 20.73 & 20.91 & 19.86 & 19.24 & 15.81 \\
\hline DM113D & 8.76 & 8.72 & 12.11 & 12.97 & 12.23 & 12.4 & 10.58 \\
\hline DM113S & 8.95 & 8.85 & 12.55 & 13.51 & 12.55 & 12.75 & 10.86 \\
\hline DM116D & -- & 6.12 & 7.72 & 7.04 & 7.60 & 7.51 & 6.80 \\
\hline DM116S & -- & 10.02 & 11.59 & 12.29 & 11.27 & 11.66 & 9.68 \\
\hline DM117D & -- & 6.00 & 7.50 & 7.77 & 7.41 & 7.22 & 6.64 \\
\hline DM117S & -- & 4.61 & 5.62 & 5.67 & 5.46 & 5.43 & 5.01 \\
\hline DM118D & - & 5.67 & 7.18 & 7.37 & 7.04 & 6.92 & 6.23 \\
\hline DM118S & -- & 5.30 & 6.38 & 6.37 & 6.15 & 6.14 & 4.68 \\
\hline DM119D & -- & 5.59 & 7.12 & 7.27 & -- & 6.84 & 6.17 \\
\hline DM119S & -- & 3.75 & 5.01 & 5.02 & -- & 4.72 & 4.21 \\
\hline DM206D & -- & - & - & - & 6.59 & 6.61 & 5.76 \\
\hline MW 10 & 8.87 & 8.83 & 11.98 & 12.75 & 12.05 & 12.00 & 10.58 \\
\hline MW12 & 8.70 & 8.71 & 12.05 & 12.86 & 12.15 & 12.1 & 10.54 \\
\hline MWl1 & 8.66 & 8.67 & 11.94 & 12.74 & 12.04 & 11.96 & 10.46 \\
\hline MW18 & 7.04 & - & 9.29 & 11.16 & 9.35 & 9.12 & 8.32 \\
\hline
\end{tabular}


Table 3. Measured ground-and surface-water level elevations at the natural-attenuation study area, Dover Air Force Base, Kent County, Delaware, July 1995 through September 1996-Continued

\begin{tabular}{|c|c|c|c|c|c|c|c|}
\hline \multirow{3}{*}{$\begin{array}{c}\text { Well } \\
\text { identification } \\
\text { number }\end{array}$} & \multicolumn{6}{|c|}{ WATER-LEVEL ELEVATIONS IN FEET ABOVE SEA LEVEL } & \\
\hline & \multicolumn{2}{|c|}{1995} & \multicolumn{5}{|c|}{1996} \\
\hline & July 24 & $\begin{array}{c}\text { December } \\
6\end{array}$ & March 6 & April 26 & June 4 & August 16 & $\begin{array}{c}\text { September } \\
19\end{array}$ \\
\hline \multicolumn{8}{|c|}{ GROUND-WATER LEVELS--CONTINUED } \\
\hline MW19 & 6.07 & 6.53 & 8.02 & 8.45 & 8.02 & 7.91 & 7.21 \\
\hline MW20 & 5.84 & 6.34 & 7.72 & 8.05 & 7.71 & 7.59 & 6.94 \\
\hline MW21 & 8.58 & 8.63 & 11.98 & 12.83 & 12.11 & 12.06 & 10.22 \\
\hline MW22 & 8.61 & 8.65 & 12.10 & 12.95 & 12.22 & 12.05 & 10.48 \\
\hline MW23 & 8.82 & 8.76 & 12.28 & 13.12 & 12.35 & 12.28 & 10.62 \\
\hline MW36D & 8.35 & 8.43 & 11.81 & 12.65 & 11.93 & 11.82 & 10.24 \\
\hline MW37D & 8.42 & 8.50 & 11.75 & 12.58 & 12.28 & 11.73 & 10.28 \\
\hline MW37S & 8.06 & 8.14 & 11.31 & 12.07 & 11.38 & 11.25 & 9.75 \\
\hline MW38D & 8.52 & 8.56 & 12.04 & 12.84 & 12.12 & -- & 10.41 \\
\hline MW38S & 8.52 & 8.60 & 12.03 & 12.87 & 12.15 & - & 10.39 \\
\hline MW39D & 8.53 & 8.55 & 11.92 & 13.73 & 12.01 & 11.83 & 14.34 \\
\hline MW39S & 8.55 & 8.55 & 11.91 & 12.76 & 12.06 & 11.99 & 10.36 \\
\hline MW40D & 8.79 & 8.74 & 12.22 & 13.08 & 12.33 & 12.33 & -- \\
\hline MW40S & 8.61 & 8.58 & 12.03 & 12.87 & 12.13 & 12.04 & -- \\
\hline MW41D & 8.8 & 8.74 & 12.30 & 13.2 & 12.38 & 12.31 & 10.65 \\
\hline MW41S & 8.78 & 8.75 & 12.29 & 13.19 & 12.4 & 12.36 & 10.69 \\
\hline MW42P & 8.54 & 8.66 & 12.09 & 12.91 & 12.18 & 12.08 & 10.50 \\
\hline MW43D & 6.05 & 6.55 & 7.94 & 8.29 & 7.94 & 5.82 & 7.17 \\
\hline MW43S & 5.88 & 6.44 & 7.76 & 8.09 & 7.75 & 5.67 & 7.03 \\
\hline MW44D & 7.07 & 7.44 & 9.19 & 9.69 & 9.21 & 9.08 & -- \\
\hline MW44S & 7.14 & 7.51 & 9.28 & 9.87 & 9.40 & 9.09 & -- \\
\hline MW61D & 9.04 & -- & 22.96 & -- & - & - & -- \\
\hline MW61S & 9.02 & 8.87 & 12.57 & 13.49 & 12.67 & 12.57 & 10.89 \\
\hline MW62D & 8.94 & 8.84 & 12.47 & 13.43 & 12.59 & 12.56 & 10.80 \\
\hline MW62S & 8.94 & 8.82 & 12.48 & 13.43 & 12.57 & 12.48 & 10.81 \\
\hline MW63D & 9.03 & 8.88 & 12.62 & 13.61 & 12.73 & -- & -- \\
\hline
\end{tabular}


Table 3. Measured ground-and surface-water level elevations at the natural-atten uation study area, Dover Air Force Base, Kent County, Delaware, July 1995 through September 1996-Continued

\begin{tabular}{|c|c|c|c|c|c|c|c|}
\hline \multirow{3}{*}{$\begin{array}{c}\text { Well } \\
\text { identification } \\
\text { number }\end{array}$} & \multicolumn{6}{|c|}{ WATER-LEVEL ELEVATIONS IN FEET ABOVE SEA LEVEL } & \\
\hline & \multicolumn{2}{|c|}{1995} & \multicolumn{5}{|c|}{1996} \\
\hline & July 24 & $\begin{array}{c}\text { December } \\
6\end{array}$ & March 6 & April 26 & June 4 & August 16 & $\begin{array}{c}\text { September } \\
19\end{array}$ \\
\hline \multicolumn{8}{|c|}{ GROUND-WATER LEVELS--CONTINUED } \\
\hline MW63S & 9.06 & 8.88 & 12.64 & 13.8 & 12.87 & -- & -- \\
\hline MW64D & 9.28 & 8.98 & 13.14 & 14.27 & 13.29 & 13.47 & 11.26 \\
\hline MW64S & 9.33 & 9.00 & 13.24 & 14.39 & 13.39 & 13.58 & 11.32 \\
\hline MW206D & 8.37 & 8.47 & 11.57 & 12.38 & 11.70 & 11.64 & 10.20 \\
\hline MW206M & 8.28 & 8.43 & 11.42 & 12.14 & 11.54 & 11.46 & 10.12 \\
\hline MW207D & -- & 8.62 & 11.64 & 12.40 & 11.75 & 11.74 & 10.29 \\
\hline MW207M & -- & 8.62 & 11.62 & 12.43 & 11.72 & 11.69 & 10.32 \\
\hline MW226D & 8.86 & 8.78 & 12.28 & 13.18 & 12.39 & 12.31 & 10.70 \\
\hline MW226M & 8.91 & 8.81 & 12.31 & 13.22 & 12.45 & 12.36 & 10.76 \\
\hline MW226S & 9.03 & 8.91 & 12.56 & 13.00 & 12.66 & 12.56 & 10.94 \\
\hline$M W^{\prime} 227 D$ & 6.33 & -- & - & - & 9.56 & 9.11 & 8.04 \\
\hline MW227M & 6.36 & - & - & - & 9.61 & 9.20 & 8.07 \\
\hline MW227S & 6.93 & -- & - & - & 9.60 & 9.83 & 9.14 \\
\hline MWD4A & -- & -- & 13.55 & 15.29 & 13.52 & 11.69 & 11.61 \\
\hline MWD4B & 8.32 & 8.59 & 11.44 & 11.94 & 11.55 & 12.00 & 10.34 \\
\hline MWD4C & 8.70 & 9.81 & 13.71 & 13.58 & 13.39 & 12.95 & 11.07 \\
\hline MWD4D & 11.48 & 12.04 & 16.66 & 16.44 & 15.75 & 15.39 & 12.98 \\
\hline MWD4E & 8.93 & 8.78 & 12.28 & 13.2 & 12.41 & 12.23 & 10.77 \\
\hline MWD4F & 7.99 & 8.22 & 10.48 & 11.15 & 10.70 & 10.91 & 9.63 \\
\hline MWD4H & 11.18 & 12.36 & 17.02 & 16.49 & 16.20 & 14.83 & 12.8 \\
\hline MWD41 & 9.61 & 7.97 & 9.36 & 10.52 & 11.06 & 11.33 & 11.05 \\
\hline GSID & -. & 8.59 & 11.61 & 12.40 & 11.73 & 11.73 & 10.29 \\
\hline GS1M & -- & 8.6 & 10.88 & 11.42 & 10.83 & 11.16 & 10.09 \\
\hline GSIS & -- & 8.72 & 9.28 & 9.59 & 9.41 & 9.77 & 9.51 \\
\hline GS2D & -- & 7.79 & 10.30 & - & - & 10.23 & 9.10 \\
\hline GS2M & -- & 8.16 & 10.26 & -- & -- & 10.36 & 9.33 \\
\hline
\end{tabular}


Table 3. Measured ground-and surface-water level elevations at the natural-attenuation study area, Dover Air Force Base, Kent County, Delaware, July 1995 through September 1996-Continued

\begin{tabular}{|c|c|c|c|c|c|c|c|}
\hline \multirow{3}{*}{$\begin{array}{c}\text { Well } \\
\text { identification } \\
\text { number }\end{array}$} & \multicolumn{6}{|c|}{ WATER-LEVEL ELEVATIONS IN FEET ABOVE SEA LEVEL } & \\
\hline & \multicolumn{2}{|c|}{1995} & \multicolumn{5}{|c|}{1996} \\
\hline & July 24 & $\begin{array}{c}\text { December } \\
6\end{array}$ & March 6 & April 26 & June 4 & August 16 & $\begin{array}{c}\text { September } \\
19\end{array}$ \\
\hline \multicolumn{8}{|c|}{ GROUND-WATER LEVELS--CONTINUED } \\
\hline GS2S & -- & 8.04 & 9.78 & - & 9.73 & 9.90 & 9.08 \\
\hline GS3M & - & 6.17 & 6.88 & 8.27 & 8.11 & 8.07 & 7.30 \\
\hline GS3S & - & 5.86 & 6.56 & 6.76 & 6.51 & 6.75 & 6.33 \\
\hline GS4D & - & 4.08 & 6.95 & 7.25 & 7.00 & 6.73 & 3.56 \\
\hline GS4M & - & 5.20 & 6.38 & 6.53 & 6.21 & 6.23 & 5.68 \\
\hline GS4S & - & 6.57 & 4.26 & 4.26 & 4.26 & 4.4 & 6.22 \\
\hline GSCPI & - & -- & - & - & -- & 7.47 & 6.74 \\
\hline GSCP3D & -- & -- & - & - & 8.90 & 8.48 & 7.13 \\
\hline GSCP3M & -- & -- & - & - & 7.70 & 7.90 & 7.13 \\
\hline GSCP4M & -- & -- & -- & - & 9.10 & 8.75 & 7.54 \\
\hline GSCP5M & - & -- & - & - & 10.90 & 9.35 & 9.22 \\
\hline GSCP6D & -- & - & - & - & 11.40 & 11.40 & 9.69 \\
\hline GSCP8 & - & -- & - & - & -- & 13.98 & 11.51 \\
\hline GSCP9S & -- & -- & -- & - & -- & 11.90 & 10.44 \\
\hline MWDD1F & -- & - & - & 6.20 & 5.44 & 5.08 & 4.89 \\
\hline \multicolumn{8}{|c|}{ SURFACE-WATER STAGE } \\
\hline GS1 staff & -- & -- & -- & - & 2.10 & 1.88 & 1.95 \\
\hline GS3 staff & -- & -- & - & - & -- & -- & 1.88 \\
\hline GS4 staff & -- & -- & - & 1.98 & 2.04 & 1.69 & 1.60 \\
\hline
\end{tabular}


Table 4. Areal electro-magnetic conductivity survey data at the natural-attenuation study area, Dover Air Force Base, Kent County, Delaware, March 1996

[Values are millimhos per meter; --, no data; locations of sites shown in figure 4]

\begin{tabular}{|c|c|c|c|c|}
\hline \multirow[t]{2}{*}{ Site } & \multicolumn{2}{|c|}{ 20-meter spacing } & \multicolumn{2}{|c|}{ 10-meter spacing } \\
\hline & $\begin{array}{c}\text { Horizontal } \\
\text { dipole }\end{array}$ & $\begin{array}{l}\text { Vertical } \\
\text { diplole }\end{array}$ & $\begin{array}{l}\text { Horizontal } \\
\text { dipole }\end{array}$ & $\begin{array}{l}\text { Vertical } \\
\text { dipole }\end{array}$ \\
\hline 1 & 11.0 & 17.0 & 6.6 & 11.0 \\
\hline 2 & 10.0 & 16.0 & 5.0 & 7.8 \\
\hline 3 & 9.6 & 11.0 & 6.4 & 7.5 \\
\hline 4 & 9.9 & 14.0 & 5.0 & 7.2 \\
\hline 5 & 9.4 & 12.0 & 6.8 & 6.0 \\
\hline 6 & 17.0 & 15.0 & 11.0 & 12.0 \\
\hline 7 & 13.0 & 19.0 & 10.0 & 13.0 \\
\hline 8 & 9.0 & 11.0 & 7.2 & 7.6 \\
\hline 9 & 9.0 & 11.5 & 7.2 & 8.0 \\
\hline 10 & 10.0 & 12.0 & 8.6 & 8.4 \\
\hline 11 & 11.5 & 12.0 & 9.6 & 9.4 \\
\hline 12 & 14.0 & 5.0 & 11.0 & 13.0 \\
\hline 13 & 10.5 & 13.0 & 5.4 & 5.2 \\
\hline 14 & 10.0 & 13.5 & 5.2 & 5.6 \\
\hline 15 & 13.5 & 17.0 & 12.0 & 27.0 \\
\hline 16 & 10.0 & 11.0 & 9.0 & 9.6 \\
\hline 17 & 10.5 & 10.0 & 9.6 & 8.6 \\
\hline 18 & 10.0 & 11.0 & 7.8 & 8.0 \\
\hline 19 & 10.0 & 12.0 & 9.9 & 10.0 \\
\hline 20 & 9.0 & 9.5 & 10.0 & 10.0 \\
\hline 21 & 10.0 & 11.0 & 9.4 & 8.2 \\
\hline 22 & 9.2 & 13.0 & 7.2 & 8.4 \\
\hline 23 & 8.0 & 14.0 & 3.6 & 8.6 \\
\hline 24 & 10.0 & 12.0 & 8.8 & 9.2 \\
\hline 25 & 10.5 & 12.5 & 8.4 & 9.6 \\
\hline 26 & 9.8 & 12.5 & 10.0 & 4.4 \\
\hline 27 & 6.6 & 13.0 & 5.0 & 7.8 \\
\hline 28 & 9.6 & 12.0 & 6.8 & 8.2 \\
\hline 29 & 11.0 & 14.0 & 8.4 & 9.8 \\
\hline 30 & 10.5 & 17.0 & 7.8 & 9.8 \\
\hline 31 & 9.0 & 16.0 & 8.0 & 11.0 \\
\hline 32 & 9.5 & 12.0 & 7.2 & 9.0 \\
\hline
\end{tabular}


Table 4. Areal electro-magnetic conductivity survey data at the natural-attenuation study area, Dover Air Force Base, Kent County, Delaware, March 1996 -Continued

\begin{tabular}{|c|c|c|c|c|}
\hline \multirow[t]{2}{*}{ Site } & \multicolumn{2}{|c|}{ 20-meter spacing } & \multicolumn{2}{|c|}{ 10-meter spacing } \\
\hline & $\begin{array}{l}\text { Horizontal } \\
\text { dipole }\end{array}$ & $\begin{array}{l}\text { Vertical } \\
\text { diplole }\end{array}$ & $\begin{array}{l}\text { Horizontal } \\
\text { dipole }\end{array}$ & $\begin{array}{l}\text { Vertical } \\
\text { dipole }\end{array}$ \\
\hline 33 & 7.2 & 10.0 & 5.2 & 6.8 \\
\hline 34 & 8.8 & 11.5 & 6.0 & 7.2 \\
\hline 35 & 9.6 & 13.0 & 6.0 & 7.8 \\
\hline 36 & 13.0 & 14.0 & 10.0 & 9.3 \\
\hline 37 & 10.0 & 12.0 & 10.0 & 8.4 \\
\hline 38 & 9.4 & 13.5 & 11.0 & 13.0 \\
\hline 39 & 11.0 & 14.0 & 11.0 & 13.0 \\
\hline 40 & 11.0 & 14.0 & 13.0 & 17.0 \\
\hline 41 & 11.0 & 13.0 & 17.0 & 16.0 \\
\hline 42 & 11.0 & 13.0 & 16.0 & 19.0 \\
\hline 43 & 11.0 & 14.5 & 15.0 & 20.0 \\
\hline 44 & 10.0 & 14.0 & 14.0 & 17.0 \\
\hline 45 & 9.6 & 13.0 & 10.0 & 12.0 \\
\hline 46 & 10.0 & 14.0 & 10.0 & 12.0 \\
\hline 47 & 13.0 & 17.0 & 12.0 & 9.4 \\
\hline 48 & 13.0 & 11.0 & 11.0 & 11.0 \\
\hline 49 & 12.0 & 13.0 & 11.0 & 13.0 \\
\hline 50 & 15.0 & 13.0 & 13.0 & 13.0 \\
\hline 51 & 10.0 & 11.0 & 8.2 & 9.6 \\
\hline 52 & 11.0 & 9.6 & 8.0 & 8.1 \\
\hline 53 & 9.0 & 12.0 & 6.4 & 9.0 \\
\hline 54 & 9.8 & 10.0 & 7.2 & 9.0 \\
\hline 55 & 9.4 & 11.0 & 6.4 & 7.6 \\
\hline 56 & 9.4 & 11.0 & 7.1 & 8.2 \\
\hline 57 & 9.8 & 9.6 & 6.2 & 5.6 \\
\hline 58 & 9.4 & 10.5 & 7.0 & 7.6 \\
\hline 59 & 9.4 & 11.0 & 6.7 & 8.1 \\
\hline 60 & 9.0 & 10.5 & 7.2 & 4.4 \\
\hline 61 & 9.6 & 10.0 & 7.2 & 5.4 \\
\hline 62 & 9.8 & 12.0 & 6.3 & 7.9 \\
\hline 63 & 9.5 & 11.0 & 7.4 & 9.4 \\
\hline 64 & 9.6 & 11.0 & 8.1 & 7.5 \\
\hline 65 & 8.6 & 9.6 & 7.3 & 7.3 \\
\hline
\end{tabular}


Table 4. Areal electro-magnetic conductivity survey data at the natural-attenuation study area, Dover Air Force Base, Kent County, Delaware, March 1996 -Continued

\begin{tabular}{|c|c|c|c|c|}
\hline \multirow[t]{2}{*}{ Site } & \multicolumn{2}{|c|}{ 20-meter spacing } & \multicolumn{2}{|c|}{ 10-meter spacing } \\
\hline & $\begin{array}{c}\text { Horizontal } \\
\text { dipole }\end{array}$ & $\begin{array}{l}\text { Vertical } \\
\text { diplole }\end{array}$ & $\begin{array}{c}\text { Horizontal } \\
\text { dipole }\end{array}$ & $\begin{array}{l}\text { Vertical } \\
\text { dipole }\end{array}$ \\
\hline 66 & 3.3 & 4.3 & 8.3 & 8.2 \\
\hline 67 & 13.4 & 13.2 & 11.8 & 13.8 \\
\hline 68 & 20.5 & 15.0 & 20.5 & 20.0 \\
\hline 69 & 17.5 & 17.0 & 18.0 & 18.0 \\
\hline 70 & 19.5 & 11.0 & 19.0 & 15.0 \\
\hline 71 & 18.0 & 12.5 & 19.5 & 13.0 \\
\hline 72 & 15.0 & 12.0 & 14.0 & 13.0 \\
\hline 73 & 12.0 & 13.0 & 9.8 & 12.0 \\
\hline 74 & 11.0 & 11.5 & 10.0 & 10.0 \\
\hline 75 & 13.0 & 10.0 & 11.0 & 14.0 \\
\hline 76 & 14.0 & 10.5 & 15.0 & 8.6 \\
\hline 77 & 12.5 & 9.4 & 11.0 & 11.5 \\
\hline 78 & 11.0 & 12.0 & 11.0 & 12.0 \\
\hline 79 & 12.0 & 13.0 & 11.0 & 10.0 \\
\hline 80 & 15.0 & 10.0 & 17.0 & 14.5 \\
\hline 81 & 16.0 & 15.0 & 13.0 & 16.0 \\
\hline 82 & 14.0 & 14.0 & 14.0 & 15.0 \\
\hline 83 & 14.5 & 15.0 & 12.0 & 16.0 \\
\hline 84 & 15.0 & 17.0 & 12.0 & 13.0 \\
\hline 85 & 15.0 & 26.0 & 10.0 & 17.0 \\
\hline 86 & 14.0 & 23.0 & 11.0 & 14.0 \\
\hline 87 & 14.0 & 18.0 & 7.8 & 9.4 \\
\hline 88 & 9.4 & 16.0 & 6.6 & 8.8 \\
\hline 89 & 9.6 & 13.0 & 7.4 & 9.2 \\
\hline 90 & 9.4 & 14.0 & 6.2 & 8.8 \\
\hline 91 & 19.0 & 13.0 & 17.0 & 16.0 \\
\hline 92 & -. & -. & -- & .. \\
\hline 93 & 13.5 & 17.0 & 11.0 & 16.3 \\
\hline 94 & 16.5 & 17.0 & 16.0 & 15.0 \\
\hline 95 & 18.0 & 18.5 & 16.0 & 18.0 \\
\hline 96 & 18.0 & 17.0 & 17.0 & 18.0 \\
\hline 97 & 17.5 & 16.0 & 13.0 & 17.0 \\
\hline 98 & 15.0 & 19.0 & 10.0 & 14.0 \\
\hline
\end{tabular}


Table 4. Areal electro-magnetic conductivity survey data at the natural-attenuation study area, Dover Air Force Base, Kent County, Delaware, March 1996 -Continued

\begin{tabular}{|c|c|c|c|c|}
\hline \multirow[t]{2}{*}{ Site } & \multicolumn{2}{|c|}{ 20-meter spacing } & \multicolumn{2}{|c|}{ 10-meter spacing } \\
\hline & $\begin{array}{c}\text { Horizontal } \\
\text { dipole }\end{array}$ & $\begin{array}{l}\text { Vertical } \\
\text { diplole }\end{array}$ & $\begin{array}{c}\text { Horizontal } \\
\text { dipole }\end{array}$ & $\begin{array}{c}\text { Vertical } \\
\text { dipole }\end{array}$ \\
\hline 99 & 15.0 & 18.0 & 12.0 & 13.0 \\
\hline 100 & 14.0 & 14.0 & 12.0 & 12.0 \\
\hline 101 & 14.0 & 15.0 & 11.0 & 13.0 \\
\hline 102 & 14.0 & 13.0 & 11.0 & 9.8 \\
\hline 103 & 12.0 & 16.0 & 9.6 & 13.0 \\
\hline 104 & 14.0 & 16.0 & 12.0 & 12.0 \\
\hline 105 & 14.0 & 15.0 & 10.0 & 12.5 \\
\hline 106 & 12.0 & 15.0 & 9.6 & 12.0 \\
\hline 107 & -- & 18.0 & .. & 22.0 \\
\hline 108 & -. & 20.0 & -. & 19.5 \\
\hline 109 & -. & 20.0 & -- & 18.0 \\
\hline 110 & -- & 17.0 & .. & 17.0 \\
\hline 111 & -- & 16.0 & -. & 21.0 \\
\hline 112 & $-\cdot$ & 13.0 & -. & 17.0 \\
\hline 113 & -- & 18.0 & -. & 20.0 \\
\hline 114 & .- & 13.0 & .. & 10.0 \\
\hline 115 & -- & 8.6 & -- & 13.0 \\
\hline 116 & -- & 15.0 & -- & 16.0 \\
\hline 117 & -- & 13.0 & -- & 16.0 \\
\hline 118 & 12.0 & 19.0 & 6.2 & 9.5 \\
\hline 119 & 11.0 & 6.0 & 8.6 & 10.0 \\
\hline 120 & 11.0 & 23.0 & 6.2 & 11.0 \\
\hline 121 & 10.0 & 19.0 & 8.4 & 5.6 \\
\hline 122 & 11.0 & 17.0 & 6.2 & 8.8 \\
\hline 123 & 12.0 & 18.0 & 7.2 & 9.8 \\
\hline 124 & 15.0 & 20.0 & 9.2 & 11.0 \\
\hline 125 & 13.0 & 19.0 & 8.0 & 13.0 \\
\hline 126 & 13.0 & 19.0 & 8.4 & 10.5 \\
\hline
\end{tabular}


Table 5. Ground-and surface-water quality data at the natural-attenuation study area, Dover Atr Force base, Kent County, Delaware, July - August 1995, May - July 1996, and August 1996, for inorganic constituents

[Locations of sample sites shown on figures 5 and $6 ; \mu \mathrm{S} / \mathrm{cm}$, microsiemens per centimeter; ${ }^{\circ} \mathrm{C}$, degrees Celsius; $\mathrm{mg} / \mathrm{L}$, milligrams per liter; --, no data; $\mathrm{nmol} / \mathrm{L}$, nanomoles per liter; $\mu \mathrm{g} / \mathrm{L}$, micrograms per liter, quality assurance samples are at end of table; (d), quality control duplicate samples; Eq. Blank, equipment blank; August, 1996 samples and all field parameters were analyzed by USGS personnel; all others were analyzed by a contract laboratory]

\begin{tabular}{|c|c|c|c|c|c|c|c|c|c|c|}
\hline \multirow[b]{2}{*}{$\begin{array}{c}\text { Sample } \\
\text { identification } \\
\text { number }\end{array}$} & \multirow[b]{2}{*}{$\begin{array}{l}\text { Sample } \\
\text { date }\end{array}$} & \multirow[b]{2}{*}{ Time } & \multicolumn{4}{|c|}{ FIELD PARAMETERS } & \multicolumn{4}{|c|}{ MAJOR IONS } \\
\hline & & & $\begin{array}{l}\text { Spe- } \\
\text { cific } \\
\text { con- } \\
\text { duc- } \\
\text { tance } \\
(\mu S / \\
\mathrm{cm})\end{array}$ & $\begin{array}{l}\mathrm{pH}, \\
\text { (stan- } \\
\text { dard } \\
\text { units) }\end{array}$ & $\begin{array}{l}\text { Tem- } \\
\text { pera- } \\
\text { ture } \\
\left({ }^{\circ} \mathrm{C}\right)\end{array}$ & $\begin{array}{l}\text { Oxy- } \\
\text { gen, } \\
\text { dis- } \\
\text { solved } \\
(\mathrm{mg} / \mathrm{L})\end{array}$ & $\begin{array}{l}\text { Hydro- } \\
\text { gen, } \\
\text { mean } \\
\text { value, } \\
(\mathrm{nmol} / \mathrm{L} \\
\text { as } \mathrm{H}_{2} \text { ) }\end{array}$ & $\begin{array}{c}\text { Cal- } \\
\text { cium } \\
\text { (mg/L } \\
\text { as } \\
\text { Ca) }\end{array}$ & $\begin{array}{c}\text { Mag- } \\
\text { nesium } \\
\text { (mg/L } \\
\text { as } \\
\mathrm{Mg} \text { ) }\end{array}$ & $\begin{array}{c}\text { So- } \\
\text { dium, } \\
(\mathrm{mg} / \mathrm{L}) \\
\text { as } \mathrm{Na})\end{array}$ \\
\hline \multicolumn{11}{|c|}{ GROUND-WATER SAMPLES } \\
\hline DM10ID & $08-03-96$ & -- & -. & 8.80 & 18.9 & 0.42 & 8.5 & 26.02 & 3.76 & 10.89 \\
\hline DM102D & $06-06-96$ & 01:00 PM & 153 & 5.54 & 18.5 & 3.32 & & 10.2 & $<5.0$ & 10.1 \\
\hline DM102D & $08-02-96$ & -. &.- & 5.05 & 19.4 & 2.22 & 0.95 & 13.76 & 5.31 & 9.60 \\
\hline DM107D & $05-02-96$ & 10:00 AM & 86 & 3.56 & 15.0 & 1.34 & & $<5.0$ & $<5.0$ & 11.7 \\
\hline DM107D & $08-02-96$ & -- & -- & 5.08 & 16.2 & 0.11 & 1.5 & 6.28 & 2.52 & 10.61 \\
\hline DM107S & $05-01-96$ & 03:30 PM & 69 & 5.27 & 10.9 & 7.0 & -. & $<5.0$ & $<5.0$ & 6.90 \\
\hline DMI0SD & $05-13-96$ & -- & 80 & 5.42 & 12.6 & 0.47 & -- & $<5.0$ & $<5.0$ & 10.50 \\
\hline DM108D & $08-02-96$ & -- & -- & 5.43 & 15.4 & 0.18 & 1.35 & 3.99 & 2.13 & 10.86 \\
\hline DM108S & $05-10-96$ & $12: 00 \mathrm{PM}$ & 94 & 4.58 & 11.5 & 1.15 & .. & $<5.0$ & $<5.0$ & 8.60 \\
\hline DM109D & $08-03-96$ &.- & -- & 8.29 & 18.1 & 0.00 & 21.2 & 8.05 & 2.73 & 10.94 \\
\hline DMHIOD & $06-13-96$ & $10: 00 \mathrm{AM}$ & 185 & 4.58 & 15.8 & 5.69 & -- & 12.3 & 5.9 & 14.4 \\
\hline DMIIOD & 08-03-96 & -- & -. & 4.94 & 16.9 & 2.30 & 4.1 & 23.65 & 11.45 & 15.06 \\
\hline DMIIOS & $08-21-95$ & $12: 15 \mathrm{PM}$ & 1751 & 5.94 & 20.5 & 0.00 & -- & 51.1 & 91.2 & 118.0 \\
\hline DM110S & $06-13-96$ & $12: 00 \mathrm{PM}$ & 1467 & 5.73 & 13.3 & 0.00 & -. & 42.9 & 74.5 & 83.0 \\
\hline DM110S & $08-03-96$ & -- & $-\cdot$ & 5.84 & 19.6 & 0.00 & 0.7 & 46.21 & 69.17 & 56.27 \\
\hline DM113D & $06-04-96$ & 03:00 PM & 101 & 5.42 & 16.9 & 5.00 & -. & $<5.0$ & $<5.0$ & 11.0 \\
\hline DM113D & $08-02-96$ & -- & -. & 6.06 & 19.0 & 3.73 & 7.8 & 10.87 & 3.28 & 12.2 \\
\hline DM113S & $08-08-95$ & 02:30 PM & 87 & 5.00 & 17.00 & 3.35 & .. & $<5.0$ & $<5.0$ & 6.80 \\
\hline DM117D & $05-21-96$ & 03:00 PM & 96 & 5.61 & 16.1 & 0.00 & -- & $<5.0$ & $<5.0$ & 8.20 \\
\hline GSID & $08-11-95$ & 10:00 AM & 107 & 5.83 & 17.6 & 0.58 & - & $<5.0$ & $<5.0$ & 9.90 \\
\hline GSID & $05-23-96$ & 01:00 PM & 124 & 6.00 & 15.6 & 0.00 & -- & $<5.0$ & $<5.0$ & 10.4 \\
\hline GS1M & $08-10-95$ & 01:00 PM & 226 & 5.51 & 20.1 & 0.5 & -. & 8.1 & $<5.0$ & 12.9 \\
\hline GSIM & $05-23-96$ & $11: 00 \mathrm{AM}$ & 74 & 5.21 & 15.0 & 0.10 & -- & $<5.0$ & $<5.0$ & 11.3 \\
\hline GSIS & $08-10-95$ & $11: 00 \mathrm{AM}$ & 146 & 5.31 & 26.2 & 1.30 & -- & $<5.0$ & $<5.0$ & 14.0 \\
\hline GSIS & $05-23-96$ & 08:00 AM & 80 & 5.54 & 15.1 & 0.00 & -- & $<5.0$ & $<5.0$ & 10.40 \\
\hline GS2D & $08-09-95$ & $11: 30 \mathrm{AM}$ & 97 & 5.85 & 19.5 & 0.75 & .. & $<5.0$ & $<5.0$ & 10.0 \\
\hline GS2D & $06-05-96$ & 08:00 AM & 68 & 5.64 & 13.8 & 0.00 & -- & $<5.0$ & $<5.0$ & 9.50 \\
\hline GS2M & $08-09-95$ & 10:00 AM & 98 & 5.49 & 22.6 & 0.50 & -- & $<5.0$ & $<5.0$ & 10.40 \\
\hline GS2M & $06-05-96$ & $11: 00 \mathrm{AM}$ & 75 & 5.77 & 13.0 & 0.00 & -- & $<5.0$ & $<5.0$ & 9.50 \\
\hline GS2S & $08-09-95$ & 08:30 AM & 97 & 5.43 & 20.6 & 0.00 & .- & $<5.0$ & $<5.0$ & 9.90 \\
\hline GS2S & $06-05-96$ & 04:00 PM & 89 & 5.68 & 14.5 & 0.00 & - & $<5.0$ & $<5.0$ & 9.70 \\
\hline GS $3 M$ & $08-28-95$ & 09:30 AM & 93 & 5.58 & 17.3 & 6.15 & -. & $<5.0$ & $<5.0$ & 10.5 \\
\hline
\end{tabular}




\begin{tabular}{|c|c|c|c|c|c|c|c|c|c|c|c|c|}
\hline \multicolumn{12}{|c|}{ MAJOR IONS } & \multirow[b]{2}{*}{$\begin{array}{c}\text { Sample } \\
\text { identification } \\
\text { number }\end{array}$} \\
\hline $\begin{array}{c}\text { Potas- } \\
\text { sium } \\
\text { (mg/ } \\
\text { L as } \\
\text { K) }\end{array}$ & $\begin{array}{c}\text { Alka- } \\
\text { linity, } \\
\text { field } \\
\text { (mg' } \\
\mathrm{L} \text { as } \\
\mathrm{Ca} \\
\mathrm{CO}_{3} \text { ) }\end{array}$ & $\begin{array}{l}\text { Hydro- } \\
\text { gen } \\
\text { sul- } \\
\text { fide, } \\
\text { field } \\
\text { (mg/L } \\
\text { as } \\
\mathrm{H}_{2} \mathrm{~S} \text { ) }\end{array}$ & $\begin{array}{c}\text { Sulfate } \\
(\mathrm{mg} / \mathrm{L} \\
\text { as } \\
\left.\mathrm{SO}_{4}\right)\end{array}$ & $\begin{array}{l}\text { Chlo- } \\
\text { ride } \\
(\mathrm{mg} / \mathrm{L} \\
\text { as Cl) }\end{array}$ & $\begin{array}{l}\text { Fluo- } \\
\text { ride } \\
\text { (mg/L } \\
\text { as F) }\end{array}$ & $\begin{array}{l}\text { Bro- } \\
\text { mide, } \\
\text { (mg/ } \\
\mathrm{L} \text { as } \\
\mathrm{Br} \text { ) }\end{array}$ & $\begin{array}{l}\text { Nitro- } \\
\text { gen, } \\
\text { am- } \\
\text { monia } \\
(\mathrm{mg} / \mathrm{L} \\
\text { as } \\
\left.\mathrm{NH}_{4}\right)\end{array}$ & $\begin{array}{l}\text { Nitro- } \\
\text { gen, } \\
\text { kjel- } \\
\text { dahl } \\
\text { (mg/L } \\
\text { as } \mathrm{N} \text { ) }\end{array}$ & $\begin{array}{l}\text { Nit- } \\
\text { rate } \\
\text { (mg/ } \\
\mathrm{L} \mathrm{as} \\
\mathrm{N})\end{array}$ & $\begin{array}{c}\mathrm{Ni}- \\
\text { trate, } \\
\text { plus } \\
\text { ni- } \\
\text { trite, } \\
\text { (mg/ } \\
\mathrm{L} \mathrm{as} \\
\mathrm{N} \text { ) }\end{array}$ & $\begin{array}{l}\text { Phos- } \\
\text { phate, } \\
\text { ortho } \\
(\mathrm{mg} / \\
\mathrm{L} \text { as } \\
\left.\mathrm{PO}_{4}\right)\end{array}$ & \\
\hline \multicolumn{13}{|c|}{ GROUND-WATER SAMPLES--CONTINUED } \\
\hline 2.87 & -- & 0.000 & 6.68 & 10.00 & -- & -- & 0.35 & -- & 2.13 & -- & $<0.02$ & DM101D \\
\hline$<5.0$ & 7.50 & 0.008 & 25.3 & 11.80 & $<0.10$ & .. & $<0.10$ & $<0.50$ & 3.4 & $<0.5$ & $<0.5$ & DMI02D \\
\hline 1.86 & -. & 0.000 & 21.33 & 9.57 & $-\cdot$ & -- & $<0.02$ & -. & 19.48 & -- & $<.02$ & DM102D \\
\hline$<5.0$ & -- & 0.003 & 4.4 & 10.80 & $<.10$ & -- & $<.10$ & $<.50$ & 0.57 & 0.57 & $<.5$ & DM107D \\
\hline 1.54 & -- & 0.000 & 3.70 & 9.95 & -- & 0.07 & $<.02$ & -- & 2.59 & - & $<.02$ & DM107D \\
\hline$<5.0$ & -- & 0.050 & 11.8 & 5.10 & $<.10$ & -. & $<.10$ & $<.50$ & $<0.5$ & 0.36 & $<.5$ & DM107S \\
\hline$<5.0$ & 7.50 & 0.000 & 5.1 & 12.00 & $<.10$ & -- & $<.10$ & $<.50$ & $<.5$ & 0.48 & $<.5$ & DM 108D \\
\hline 1.53 & -- & 0.000 & 4.00 & 10.10 & -- & 0.16 & $<.02$ & -- & 1.13 & -- & $<.02$ & DM108D \\
\hline$<5.0$ & -- & 0.004 & 15.4 & 9.60 & $<.10$ & -- & $<.10$ & $<.50$ & 0.56 & 0.57 & $<.5$ & DM108S \\
\hline 1.03 & -- & 0.000 & 11.04 & 7.65 & -- & -- & 0.69 & .. & 0.18 & $-\cdot$ & $<.02$ & DMI09D \\
\hline$<5.0$ & $-\cdot$ & 0.014 & 74.2 & 6.10 & $<.10$ & -- & $<.10$ & $<.50$ & 0.69 & 0.79 & $<.5$ & DMI10D \\
\hline 1.63 & -- & 0.000 & 81.43 & 4.11 & -- & -- & $<.02$ & -- & 1.77 & -- & $<.02$ & DMI10D \\
\hline$<5.0$ & 390.0 & 0.021 & 37.3 & 304.00 & $<.10$ & -- & $<.10$ & 1.8 & 1.2 & $<.5$ & $<.5$ & DM110S \\
\hline$<5.0$ & 268.0 & 0.022 & 69.2 & 250.00 & $<.10$ & -. & 0.15 & 1.2 & 1.2 & $<.5$ & $<.5$ & DM110S \\
\hline 0.37 & -- & 0.002 & 45.38 & 372.71 & -. & 4.54 & $<.02$ & -- & $<0.02$ & -- & $<.02$ & DMHOS \\
\hline$<5.0$ & 14.5 & 0.002 & 0.76 & 13.40 & $<.10$ & -- & $<.10$ & $<.50$ & 2.2 & 2.5 & $<.5$ & DMII3D \\
\hline 4.2 & -- & 0.008 & 0.52 & 11.39 & -- & -- & $<.02$ & -. & 11.81 & $-\cdot$ & $<.02$ & DM113D \\
\hline 5.4 & 7.5 & 0.000 & 17.9 & 3.30 & $<.10$ & -- & $<.10$ & $<.50$ & 0.66 & 0.7 & $<.5$ & DMll3S \\
\hline$<5.0$ & 17.0 & 0.042 & 16.2 & 4.70 & $<.10$ & -- & $<.10$ & $<.50$ & $<.5$ & $<.5$ & $<.5$ & DM117D \\
\hline$<5.0$ & 42.5 & 0.011 & 1.5 & 11.30 & $<.10$ & -. & $<.10$ & $<.50$ & $<.5$ & $<.5$ & $<.5$ & GSID \\
\hline$<5.0$ & 45.0 & 0.007 & $<0.50$ & 11.00 & $<.10$ & $-\cdot$ & $<.10$ & $<.50$ & $<.5$ & $<.5$ & $<.5$ & GSID \\
\hline$<5.0$ & 8.05 & 0.006 & 3.3 & 15.40 & $<.10$ & -. & 3.3 & 3.8 & $<.5$ & $<.5$ & $<.5$ & GSIM \\
\hline$<5.0$ & 4.50 & 0.010 & 4.3 & $<0.50$ & $<.10$ & -- & $<.10$ & $<.50$ & $<.5$ & 0.18 & $<.5$ & GSIM \\
\hline$<5.0$ & 4.85 & 0.000 & 3.7 & 12.90 & $<.10$ & -- & $<.10$ & $<.50$ & $<.5$ & $<.5$ & $<.5$ & GSIS \\
\hline$<5.0$ & 13.0 & 0.000 & 5.8 & 10.20 & $<.10$ & -. & $<.10$ & $<.50$ & $<.5$ & $<.5$ & $<.5$ & GSIS \\
\hline$<5.0$ & 20.5 & 0.025 & 4.0 & 9.90 & $<.10$ & .- & $<.10$ & $<.50$ & $<.5$ & $<.5$ & $<.5$ & GS2D \\
\hline$<5.0$ & 17.3 & 0.008 & 3.8 & 10.60 & $<.10$ & -- & $<.10$ & $<.50$ & $<.5$ & $<.5$ & $<.5$ & GS2D \\
\hline$<5.0$ & 20.5 & 0.025 & 4.9 & 10.30 & $<.10$ & -- & $<.10$ & $<.50$ & $<.5$ & $<.5$ & $<.5$ & GS2M \\
\hline$<5.0$ & 21.5 & 0.014 & 4.4 & 10.80 & $<.10$ & -- & $<.10$ & $<.50$ & $<.5$ & $<.5$ & $<.5$ & GS2M \\
\hline$<5.0$ & 23.0 & 0.006 & 4.9 & 9.20 & $<.10$ & -. & 0.21 & $<.50$ & $<.5$ & $<.5$ & $<.5$ & GS2S \\
\hline$<5.0$ & 18.5 & 0.002 & 5.9 & 9.50 & $<.10$ & -- & 0.1 & $<.50$ & $<.5$ & $<.5$ & $<.5$ & GS2S \\
\hline$<5.0$ & 10.0 & 0.025 & 18.9 & 4.70 & $<.10$ & -- & $<.10$ & $<.50$ & $<.5$ & 0.24 & $<.5$ & GS3M \\
\hline
\end{tabular}


Table 5. Ground-and surface-water quality data at the natural-attenuation study area, Dover Air Force Base, Kent County, Delaware, July - August 1995, May - July 1996, and August 1996, for inorganic

constituents-Continued

\begin{tabular}{|c|c|c|c|c|c|c|c|c|c|c|}
\hline \multirow[b]{2}{*}{$\begin{array}{c}\text { Sample } \\
\text { identification } \\
\text { number }\end{array}$} & \multirow[b]{2}{*}{$\begin{array}{l}\text { Sample } \\
\text { date }\end{array}$} & \multirow[b]{2}{*}{ Time } & \multicolumn{4}{|c|}{ FIELD PARAMETERS } & \multicolumn{4}{|c|}{ MAJOR IONS } \\
\hline & & & $\begin{array}{l}\text { Spe- } \\
\text { cific } \\
\text { con- } \\
\text { duc- } \\
\text { tance } \\
(\mu \mathrm{S} / \\
\mathrm{cm})\end{array}$ & $\begin{array}{c}\mathrm{pH}, \\
\text { (stan- } \\
\text { dard } \\
\text { units) } \\
.\end{array}$ & $\begin{array}{l}\text { Tem- } \\
\text { pera- } \\
\text { ture } \\
\left({ }^{\circ} \mathrm{C}\right)\end{array}$ & $\begin{array}{c}\text { Oxy- } \\
\text { gen, } \\
\text { dis- } \\
\text { solved } \\
(\mathrm{mg} / \mathrm{L})\end{array}$ & $\begin{array}{c}\text { Hydro- } \\
\text { gen, } \\
\text { mean } \\
\text { value, } \\
(\mathrm{nmol} / \mathrm{L} \\
\left.\text { as } \mathrm{H}_{2}\right)\end{array}$ & $\begin{array}{c}\text { Cal- } \\
\text { cium } \\
\text { (mg/L } \\
\text { as } \\
\text { Ca) }\end{array}$ & $\begin{array}{c}\text { Mag- } \\
\text { nesium } \\
\text { (mg/L } \\
\text { as } \\
\mathrm{Mg} \text { ) }\end{array}$ & $\begin{array}{c}\text { So- } \\
\text { dium, } \\
\text { (mg/L) } \\
\text { as } \mathrm{Na})\end{array}$ \\
\hline \multicolumn{11}{|c|}{ GROUND-WATER SAMPLES--CONTINUED } \\
\hline GS3M(d) & $05-22-96$ & -- & $-\cdot$ & -- & -. & -- & -- & $<5.0$ & $<5.0$ & 9.6 \\
\hline GS3M & $05-22-96$ & 02:00 PM & 87 & 5.66 & 14.2 & 7.1 & -- & $<5.0$ & $<5.0$ & 9.4 \\
\hline GS3S & $08-17-95$ & 02:00 PM & 338 & 6.12 & 18.9 & 0.00 & -- & 15.3 & 12.1 & 13.1 \\
\hline GS3S & $05-22-96$ & 08:00 AM & 278 & 6.26 & 13.3 & 0.00 & -. & 16.1 & 11.5 & 10.0 \\
\hline GS4D & $08-17-95$ & $10: 00 \mathrm{AM}$ & 110 & 5.94 & 17.3 & 0.00 & -- & 5.8 & $<5.0$ & 9.0 \\
\hline GS4D & $05-20-96$ & 09:00 AM & 108 & 5.99 & 13.5 & 0.00 & -- & 6.1 & $<5.0$ & 7.1 \\
\hline GS4M & $08-16-95$ & $12: 30 \mathrm{PM}$ & 90 & 5.45 & 18.4 & 0.00 & -- & $<5.0$ & $<5.0$ & 6.6 \\
\hline GS4M & $05-20-96$ & 12:00 PM & 91 & 5.56 & 16.2 & 0.00 & .. & $<5.0$ & $<5.0$ & 6.9 \\
\hline GS4S & $08-16-95$ & 09:30 AM & 92 & 5.62 & 19.5 & 0.00 & -. & $<5.0$ & $<5.0$ & 6.3 \\
\hline GS4S & $05-20-96$ & 01:00 PM & 108 & 5.58 & 13.5 & 0.00 & -- & $<5.0$ & $<5.0$ & 7.3 \\
\hline GS $こ P 3 D$ & $06-11-96$ & 09:30 AM & 82 & 5.2 & 16.6 & 2.21 & -- & $<5.0$ & $<5.0$ & 10.7 \\
\hline GSCP3D & $08-02-96$ & -- & -. & 5.38 & 17.9 & 0.00 & 1.95 & 6.73 & 3.49 & 12.47 \\
\hline GSCP3M & $06-11-96$ & 11:00 AM & 130 & 5.67 & 15.8 & 0.00 & -- & $<5.0$ & $<5.0$ & 12.0 \\
\hline GSCP3M & $08-02-96$ & -- & $-\cdot$ & 5.32 & 17.4 & 2.10 & 1.75 & 4.73 & 2.21 & 10.21 \\
\hline GSCP4M & $06-11.96$ & 01:30 PM & 120 & 5.53 & 14.9 & 0.00 & -- & $<5.0$ & $<5.0$ & 12 \\
\hline GSCP4M & $08-02-96$ & -- & .. & 5.81 & 15.7 & 0.00 & 0.79 & 6.85 & 3.64 & 11.73 \\
\hline GSCP5M & $06-07-96$ & 09:30 AM & 122 & 5.69 & 15.9 & 0.00 & -- & $<5.0$ & $<5.0$ & 12.7 \\
\hline GSCP5M(d) & $06-07-96$ & -- & -. & -- & -- & -- & -. & $<5.0$ & $<5.0$ & 13.1 \\
\hline GSCP5M & $08-02-96$ & -- & -. & 5.33 & 17.5 & 0.00 & 1.01 & 4.57 & 2.23 & 12.65 \\
\hline GSCP6D & $06-10-96$ & 01:30 PM & 135 & 5.38 & 17.6 & 0.00 & -. & $<5.0$ & $<5.0$ & $<5.0$ \\
\hline GSCP6D & $08-02-96$ & -. & -. & 5.82 & 17.0 & 0.00 & 5.5 & 4.75 & 1.94 & 8.35 \\
\hline GSCP8 & $07-11-96$ & 10:00 AM & 121 & 4.94 & 15.8 & 0.82 & -- & 10.2 & $<5.0$ & 14.8 \\
\hline GSCP9S & $06-12-96$ & 04:00 PM & 98 & 5.4 & 27 & 0.00 & - & $<5.0$ & $<5.0$ & 10.4 \\
\hline GSCP9S & $08-03-96$ & -. & -- & 5.08 & 16.1 & 0.00 & 2.8 & 8.78 & 4.23 & 9.63 \\
\hline MWlI & $08-22-95$ & 01:00 PM & 103 & 5.2 & 16.4 & 0.70 & -. & $<5.0$ & $<5.0$ & 11 \\
\hline MW18 & 08-03-95 & 02:30 PM & 86 & 5.06 & 19.4 & 6.6 & -- & $<5.0$ & $<5.0$ & 8 \\
\hline MW19 & $08-08-95$ & 08:30 AM & 106 & 5.13 & 16.6 & 3.1 & -- & $<5.0$ & $<5.0$ & 10.4 \\
\hline MWI9 & $05-17-96$ & 12:00 PM & 125 & 5.55 & 14.8 & 3.7 & -- & 5.7 & $<5.0$ & 10.8 \\
\hline MW19 & $08-03-96$ & -- & -- & 5.25 & 17.5 & 4.48 & 3.4 & 11.00 & 4.60 & 10.55 \\
\hline MW20 & $07-28-95$ & 09:00 AM & 74 & 4.96 & 18.8 & 3.85 & -- & $<5.0$ & $<5.0$ & 6.7 \\
\hline MW21 & $07-27-95$ & 01:00 PM & 87 & 5.23 & 19.8 & 0.15 & -. & $<5.0$ & $<5.0$ & 10.2 \\
\hline MW37D & $07-27.95$ & $09: 30 \mathrm{AM}$ & 103 & 4.78 & 17.6 & 0.20 & -. & $<5.0$ & $<5.0$ & 12.3 \\
\hline
\end{tabular}




\begin{tabular}{|c|c|c|c|c|c|c|c|c|c|c|c|c|}
\hline \multicolumn{12}{|c|}{ MAJOR IONS } & \multirow[b]{2}{*}{$\begin{array}{c}\text { Sample } \\
\text { identification } \\
\text { number }\end{array}$} \\
\hline $\begin{array}{c}\text { Potas- } \\
\text { sium } \\
\text { (mg/ } \\
\mathrm{L} \text { as } \\
\mathrm{K} \text { ) }\end{array}$ & $\begin{array}{c}\text { Alka- } \\
\text { linity, } \\
\text { field } \\
\text { (mg/ } \\
\mathrm{L} \mathrm{as} \\
\mathrm{Ca} \\
\left.\mathrm{CO}_{3}\right)\end{array}$ & $\begin{array}{c}\text { Hydro- } \\
\text { gen } \\
\text { sul- } \\
\text { fide, } \\
\text { field } \\
\text { (mg/L } \\
\text { as } \\
\mathrm{H}_{2} \mathrm{~S} \text { ) }\end{array}$ & $\begin{array}{l}\text { Sulfate } \\
(\mathrm{mg} / \mathrm{L} \\
\text { as } \\
\left.\mathrm{SO}_{4}\right)\end{array}$ & $\begin{array}{l}\text { Chlo- } \\
\text { ride } \\
(\mathrm{mg} / \mathrm{L} \\
\text { as Cl) }\end{array}$ & $\begin{array}{l}\text { Fluo- } \\
\text { ride } \\
\text { (mg/L } \\
\text { as F) }\end{array}$ & $\begin{array}{l}\text { Bro- } \\
\text { mide, } \\
\text { (mg/ } \\
\mathrm{L} \text { as } \\
\mathrm{Br} \text { ) }\end{array}$ & $\begin{array}{c}\text { Nitro- } \\
\text { gen, } \\
\text { am- } \\
\text { monia } \\
(\mathrm{mg} / \mathrm{L} \\
\text { as } \\
\left.\mathrm{NH}_{4}\right)\end{array}$ & $\begin{array}{l}\text { Nitro- } \\
\text { gen, } \\
\text { kjel- } \\
\text { dahl } \\
\text { (mg/L } \\
\text { as } \mathrm{N})\end{array}$ & $\begin{array}{l}\text { Nit- } \\
\text { rate } \\
\text { (mg/ } \\
\text { L as } \\
\mathrm{N})\end{array}$ & $\begin{array}{c}\mathrm{Ni}- \\
\text { trate, } \\
\text { plus } \\
\text { ni- } \\
\text { trite, } \\
\text { (mg/ } \\
\mathrm{L} \text { as } \\
\mathrm{N} \text { ) }\end{array}$ & $\begin{array}{l}\text { Phos- } \\
\text { phate, } \\
\text { ortho } \\
\text { (mg/ } \\
\mathrm{L} \mathrm{as} \\
\mathrm{PO}_{4} \text { ) }\end{array}$ & \\
\hline \multicolumn{13}{|c|}{ GROUND-WATER SAMPLES--CONTINUED } \\
\hline$<5.0$ & $-\cdot$ & -- & 17.1 & 4.40 & $<.10$ & -- & $<.10$ & $<.50$ & $<.5$ & 0.29 & $<.5$ & GS3M(d) \\
\hline$<5.0$ & 9.50 & 0.003 & 17.2 & 4.50 & $<.10$ & -. & $<.10$ & $<.50$ & $<.5$ & 0.29 & $<.5$ & GS3M \\
\hline$<5.0$ & 120.0 & 0.016 & 11.6 & 32.40 & $<.10$ & -- & $<.10$ & $<.50$ & $<.5$ & 84.1 & $<.5$ & GS3S \\
\hline$<5.0$ & 65.0 & 0.007 & 15.6 & 21.50 & $<.10$ & -- & $<.10$ & $<.50$ & $<.5$ & $<.5$ & $<.5$ & GS3S \\
\hline$<5.0$ & $-\cdot$ & $\cdot 0.058$ & 12.8 & 6.60 & $<.10$ & -- & 0.17 & $<.50$ & $<.5$ & $<.5$ & $<.5$ & GS4D \\
\hline$<5.0$ & 22.5 & 0.000 & 15.8 & 5.10 & $<.10$ & .. & 0.13 & $<.50$ & $<.5$ & $<.5$ & $<.5$ & GS4D \\
\hline$<5.0$ & 8.0 & 0.680 & 21.3 & 3.80 & $<.10$ & -- & $<.10$ & $<.50$ & 0.52 & $<.5$ & $<.5$ & GS4M \\
\hline$<5.0$ & 10.5 & 0.030 & 23.3 & 3.80 & $<.10$ & -- & $<.10$ & $<.50$ & $<.5$ & $<.5$ & $<.5$ & GS4M \\
\hline$<5.0$ & 18.5 & 0.171 & 21.1 & 3.80 & $<.10$ & -- & 0.1 & $<.50$ & $<.5$ & $<.5$ & $<.5$ & GS4S \\
\hline$<5.0$ & 10.0 & 0.000 & 23.8 & 5.40 & $<.10$ & -- & 0.13 & $<.50$ & $<.5$ & $<.5$ & $<.5$ & GS4S \\
\hline$<5.0$ & 7.5 & 0.009 & 9.4 & 8.60 & $<.10$ & -- & $<.10$ & $<.50$ & $<.5$ & 0.42 & $<.5$ & GSCP3D \\
\hline 0.84 & -- & 0.000 & 1.03 & 12.62 & -- & 0.04 & 1.34 & -- & $<.02$ & -- & $<.02$ & GSCP3D \\
\hline$<5.0$ & 35.50 & 0.035 & 1.4 & 13.60 & $<.10$ & -- & 0.16 & $<.50$ & $<.5$ & $<.5$ & $<.5$ & GSCP3M \\
\hline 1.03 & -- & 0.000 & 6.358 & 6.39 & -- & $-\cdot$ & $<.02$ & -- & 1.07 & - & $<.02$ & GSCP3M \\
\hline$<5.0$ & 18.50 & 0.033 & 12.3 & 12.30 & $<.10$ & -- & 0.13 & $<.50$ & $<.5$ & $<.5$ & $<.5$ & GSCP4M \\
\hline 0.81 & -- & 0.034 & 7.73 & 12.04 & -- & 0.04 & 0.89 & -- & $<.02$ & -- & $<.02$ & GSCP4M \\
\hline$<5.0$ & 22.00 & 0.000 & 6.2 & 16.0 & $<.10$ & $-\cdot$ & $<.10$ & $<.50$ & $<.5$ & $<.5$ & $<.5$ & GSCP5M \\
\hline$<5.0$ & $-\cdot$ & -- & 6.2 & 15.90 & $<.10$ & $-\cdot$ & $<.10$ & $<.50$ & $<.5$ & $<.5$ & $<.5$ & GSCP5M(d) \\
\hline 1.10 & $-\cdot$ & 0.000 & 4.71 & 10.17 & -- & 0.06 & 0.94 & -. & 0.123 & -- & $<.02$ & GSCP5M \\
\hline$<0.0$ & 13.00 & 0.000 & $<.50$ & $<.50$ & $<.10$ & -- & $<.10$ & -- & -- & -- & - & GSCP6D \\
\hline 0.81 & $-\cdot$ & 0.000 & 6.426 & 6.65 & -- & -- & 0.56 & -- & 0.213 & -. & $<.02$ & GSCP6D \\
\hline$<50$ & 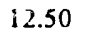 & 0.000 & 22.6 & 8.60 & $<.10$ & -- & 0.11 & $<.50$ & $<.5$ & $<.5$ & $<.5$ & GSCP8 \\
\hline$<5.0$ & 19.00 & 0.026 & 15.4 & 4.40 & $<.10$ & -- & $<.10$ & $<.50$ & $<.5$ & $<.5$ & $<.5$ & GSCP9S \\
\hline 1.13 & $-\cdot$ & 0.000 & 10.89 & 3.36 & -- & -. & $<.02$ & - & 0.041 & -- & $<.02$ & GSCP9S \\
\hline$<5.0$ & 22.00 & 0.004 & 10.6 & 7.60 & $<.10$ & -- & $<.10$ & $<.50$ & $<.5$ & $<.5$ & $<.5$ & MW11 \\
\hline$<5.0$ & 8.00 & 0.001 & 20.4 & 3.0 & $<.10$ & -- & $<.10$ & $<.50$ & $<.5$ & 0.27 & $<.5$ & MW18 \\
\hline 11 & 17.50 & 0.003 & 6.4 & $<.50$ & 0.13 & $-\cdot$ & $<.10$ & $<.50$ & 0.72 & 0.62 & $<.5$ & MW19 \\
\hline$<5.0$ & 22.00 & 0.003 & 10.7 & 7.40 & $<.10$ & -- & 0.48 & 0.51 & 0.6 & 1.1 & $<.5$ & MW19 \\
\hline 1.03 & $-\cdot$ & 0.000 & 9.74 & 6.33 & -- & 0.21 & 3.26 & -- & 2.55 & -- & $<.02$ & MW19 \\
\hline$<5.0$ & 4.50 & 0.000 & 15.6 & 3.40 & $<.10$ & $-\cdot$ & $<.10$ & $<.50$ & $<.5$ & 0.44 & $<.5$ & MW20 \\
\hline$<5.0$ & 4.00 & 0.000 & 12.1 & 10.10 & $<.10$ & -. & $<.10$ & $<.50$ & $<.5$ & $<.5$ & $<.5$ & MW21 \\
\hline$<5.0$ & 8.50 & 0.000 & 14.0 & 11.60 & $<.10$ & -- & $<.10$ & $<.50$ & 0.51 & 0.4 & $<.5$ & MW37D \\
\hline
\end{tabular}


Table 5. Ground-and surface-water quality data at the natural-attenuation study area, Dover Air Force Base, Kent County, Delaware, July - August 1995, May - July 1996, and August 1996, for inorganic constituents-Continued

\begin{tabular}{|c|c|c|c|c|c|c|c|c|c|c|}
\hline \multirow[b]{2}{*}{$\begin{array}{c}\text { Sample } \\
\text { identification } \\
\text { number }\end{array}$} & \multirow[b]{2}{*}{$\begin{array}{c}\text { Sample } \\
\text { date }\end{array}$} & \multirow[b]{2}{*}{ Time } & \multicolumn{4}{|c|}{ FIELD PARAMETERS } & \multicolumn{4}{|c|}{ MAJOR IONS } \\
\hline & & & $\begin{array}{l}\text { Spe- } \\
\text { cific } \\
\text { con- } \\
\text { duc- } \\
\text { tance } \\
(\mu \mathrm{S} / \\
\mathrm{cm})\end{array}$ & $\begin{array}{l}\mathrm{pH}, \\
\text { (stan- } \\
\text { dard } \\
\text { units) }\end{array}$ & $\begin{array}{l}\text { Tem- } \\
\text { pera- } \\
\text { ture } \\
\left({ }^{\circ} \mathrm{C}\right)\end{array}$ & $\begin{array}{l}\text { Oxy- } \\
\text { gen, } \\
\text { dis- } \\
\text { solved } \\
(\mathrm{mg} / \mathrm{L})\end{array}$ & $\begin{array}{l}\text { Hydro- } \\
\text { gen, } \\
\text { mean } \\
\text { value, } \\
(\mathrm{nmol} / \mathrm{L} \\
\text { as } \mathrm{H}_{2} \text { ) }\end{array}$ & $\begin{array}{c}\text { Cal- } \\
\text { cium } \\
(\mathrm{mg} / \mathrm{L} \\
\text { as } \\
\mathrm{Ca})\end{array}$ & $\begin{array}{c}\text { Mag- } \\
\text { nesium } \\
\text { (mg/L } \\
\text { as } \\
\mathrm{Mg} \text { ) }\end{array}$ & $\begin{array}{c}\text { So- } \\
\text { dium, } \\
\text { (mg/L) } \\
\text { as } \mathrm{Na})\end{array}$ \\
\hline \multicolumn{11}{|c|}{ GROUND-WATER SAMPLES--CONTINUED } \\
\hline MW37S & $08-07-95$ & $11: 30 \mathrm{AM}$ & 103 & 5.12 & 16.1 & 1.59 & -. & $<5.0$ & $<5.0$ & 17.3 \\
\hline MW37S(d) & $08-07-95$ &.- & -. & -. & -- & -- & -- & $<5.0$ & $<5.0$ & 17.6 \\
\hline MW37S & $05-28-96$ & 02:00 PM & 118 & 5.16 & 12.6 & 1.83 & -. & $<5.0$ & $<5.0$ & 15.7 \\
\hline MW37S & $08-02-96$ & $\cdots$ & -- & 5.31 & 17.6 & 0.85 & 1.35 & 6.26 & 3.43 & 15.88 \\
\hline MW39D & $08-01-95$ & $11: 00 \mathrm{AM}$ & 98 & 5.09 & 17.7 & 1.5 & & $<5.0$ & $<5.0$ & 11.1 \\
\hline MW39D(d) & $08-01-95$ & -- & -. & - & -- & -- & $\cdots$ & $<5.0$ & $<5.0$ & 10.7 \\
\hline MW39S & $07-26-95$ & 03:00 PM & 171 & 4.89 & 17.7 & 0.20 & -. & $<5.0$ & $<5.0$ & 22.2 \\
\hline MW39S & $06-12-96$ & 01:00 PM & 171 & 5.18 & 14.5 & 0.00 & - & 5.1 & $<5.0$ & 20.8 \\
\hline MW39S & $08-03-95$ & -- & -- & 5.04 & 18.1 & 2.72 & 2.40 & 8.61 & 5.56 & 21.65 \\
\hline MW40D & $08-03-95$ & $11: 25 \mathrm{AM}$ & 71 & 5.28 & 17.9 & 4.05 & $\cdot$ & $<5.0$ & $<5.0$ & 8.1 \\
\hline MW $40 \mathrm{~S}$ & $08-03-95$ & $10: 00 \mathrm{AM}$ & 93 & 4.91 & 19.1 & 3.6 & $\ldots$ & $<5.0$ & $<5.0$ & 13 \\
\hline MW 41D & $07-31-95$ & 01:00 PM & 72 & 5.21 & 16.7 & 4.8 & -. & $<5.0$ & $<5.0$ & 8.2 \\
\hline MW41S & $08-01-95$ & 08:00 AM & 180 & 5.36 & 13.7 & 0.2 & $\cdots$ & $<5.0$ & $<5.0$ & 24.7 \\
\hline MW43S & $07-26-95$ & $10: 00 \mathrm{AM}$ & 72 & 5.14 & 17.0 & 1.5 & -- & $<5.0$ & $<5.0$ & 7.3 \\
\hline MW43S(d) & $07-26-95$ & - & -. & -- & -- & -. & -- & $<5.0$ & $<5.0$ & 7.8 \\
\hline MW61S & $08-04-95$ & 09:00 AM & 1547 & 5.85 & 15.9 & 0.66 & $-\cdot$ & 55.9 & 43.1 & 155 \\
\hline MW61S & $08-15-95$ & 09:00 AM & -- & -- & -- & -. & -- & -- & -- & $\ldots$ \\
\hline MW61S & $06-21-96$ & 12:00 PM & 1612 & 5.89 & 22.0 & 0.00 & -- & 60.1 & 45.6 & 185 \\
\hline MW61S & $08-03-96$ & -. & -- & 5.70 & 18.0 & 0.00 & 2.75 & 65.97 & 48.56 & 138.22 \\
\hline MW62D & $06-19-96$ & $11: 30 \mathrm{AM}$ & 59 & 5.25 & 14.7 & 7.6 & -- & $<5.0$ & $<5.0$ & 8.8 \\
\hline MW62S & $06-18-96$ & 01:00 PM & 117 & 5.36 & 16.4 & 0.00 & -- & $<5.0$ & $<5.0$ & 18.1 \\
\hline MW62S & $08-03-96$ & -- & -- & 5.42 & 16.8 & 0.00 & 9.80 & 7.32 & 3.84 & 15.39 \\
\hline MW64S & $06-14-96$ & $10: 00 \mathrm{AM}$ & 557 & 5.08 & 18.5 & 0.00 & -- & 33.7 & 23.9 & 40.1 \\
\hline MW64S(d) & $06-14-96$ & -- & -. & -- & -- & -- & -- & 33.8 & 24.2 & 41.4 \\
\hline MW206D & $08-01-95$ & $08: 00 \mathrm{AM}$ & 81 & 5.07 & 16.8 & 1.8 & -- & $<5.0$ & $<5.0$ & 10.2 \\
\hline MW206D & $05-31-96$ & 09:30 AM & 85 & 5.03 & 15.6 & 1.51 & -- & $<5.0$ & $<5.0$ & 10.8 \\
\hline MW206D(d) & $05-31-96$ & -- & -. & -. & -- & -- & -. & $<5.0$ & $<5.0$ & 10.5 \\
\hline MW206M & $08-07-95$ & 03:00 PM & 85 & 5.14 & 17.6 & 1.82 & -- & $<5.0$ & $<5.0$ & 9.7 \\
\hline MW206M & $05-30-96$ & 09:00 AM & 90 & 5.28 & 13.8 & 1.22 & -. & $<5.0$ & $<5.0$ & 9.2 \\
\hline MW206M & $08.03-96$ & -- & -. & 5.05 & 17.9 & 0.78 & 3.80 & 8.01 & 4.06 & 10.74 \\
\hline MW226D & $08-02-95$ & $08: 30 \mathrm{AM}$ & 75 & 5 & 16.5 & 5.0 & .. & $<5.0$ & $<5.0$ & 8.4 \\
\hline MW226M & $08-02-95$ & 09:00 AM & 86 & 5.21 & 19 & 1.67 & .. & $<5.0$ & $<5.0$ & 10.8 \\
\hline
\end{tabular}




\begin{tabular}{|c|c|c|c|c|c|c|c|c|c|c|c|c|}
\hline \multicolumn{12}{|c|}{ MAJOR IONS } & \multirow[b]{2}{*}{$\begin{array}{c}\text { Sample } \\
\text { identification } \\
\text { number }\end{array}$} \\
\hline $\begin{array}{c}\text { Potas- } \\
\text { sium } \\
\text { (mg/ } \\
\text { L as } \\
\mathrm{K} \text { ) }\end{array}$ & $\begin{array}{c}\text { Alka- } \\
\text { linity, } \\
\text { field } \\
\text { (mg/ } \\
\mathrm{L} \mathrm{as} \\
\mathrm{Ca} \\
\left.\mathrm{CO}_{3}\right)\end{array}$ & $\begin{array}{l}\text { Hydro- } \\
\text { gen } \\
\text { sul- } \\
\text { fide, } \\
\text { field } \\
\text { (mg/L } \\
\text { as } \\
\mathrm{H}_{2} \mathrm{~S} \text { ) }\end{array}$ & 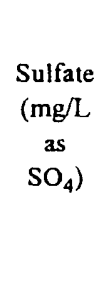 & $\begin{array}{l}\text { Chlo- } \\
\text { ride } \\
(\mathrm{mg} / \mathrm{L} \\
\text { as } \mathrm{Cl})\end{array}$ & $\begin{array}{l}\text { Fluo- } \\
\text { ride } \\
(\mathrm{mg} / \mathrm{L} \\
\text { as } \mathrm{F} \text { ) }\end{array}$ & $\begin{array}{c}\text { Bro- } \\
\text { mide, } \\
\text { (mg/ } \\
\mathrm{L} \text { as } \\
\mathrm{Br})\end{array}$ & $\begin{array}{l}\text { Nitro- } \\
\text { gen, } \\
\text { am- } \\
\text { monia } \\
(\mathrm{mg} / \mathrm{L} \\
\text { as } \\
\left.\mathrm{NH}_{4}\right)\end{array}$ & $\begin{array}{l}\text { Nitro- } \\
\text { gen, } \\
\text { kjel- } \\
\text { dahl } \\
\text { (mg/L } \\
\text { as N) }\end{array}$ & $\begin{array}{l}\text { Nit- } \\
\text { rate } \\
\text { (mg/ } \\
\mathrm{L} \text { as } \\
\mathrm{N})\end{array}$ & $\begin{array}{l}\mathrm{Ni}- \\
\text { trate, } \\
\text { plus } \\
\text { ni- } \\
\text { trite, } \\
\text { (mg/ } \\
\mathrm{L} \text { as } \\
\mathrm{N} \text { ) }\end{array}$ & $\begin{array}{l}\text { Phos- } \\
\text { phate, } \\
\text { ortho } \\
\text { (mg/ } \\
\mathrm{L} \text { as } \\
\mathrm{PO}_{4} \text { ) }\end{array}$ & \\
\hline \multicolumn{13}{|c|}{ GROUND-WATER SAMPLES--CONTINUED } \\
\hline$<5.0$ & 12.60 & 0.004 & 23.3 & 6.50 & $<.10$ & -- & $<.10$ & $<.50$ & 0.6 & 0.52 & $<.5$ & MW37S \\
\hline$<5.0$ & -- & -- & 23.6 & 6.50 & $<10$ & -- & $<.10$ & $<.50$ & 0.61 & 0.54 & $<.5$ & MW37S(d) \\
\hline$<5.0$ & 14.50 & 0.009 & 23.4 & 6.40 & $<.10$ & -- & $<.10$ & 0.81 & $<.5$ & 1.2 & $<.5$ & MW37S \\
\hline 0.77 & -. & 0.000 & 18.81 & 5.11 & -- & 0.04 & $<.02$ & -. & 1.94 & -. & $<.02$ & MW37S \\
\hline$<5.0$ & 14.00 & 0.000 & 9 & 10.30 & $<.10$ & -- & $<.10$ & $<.50$ & 0.8 & 0.82 & $<.5$ & MW39D \\
\hline$<5.0$ & .. & -- & 9.1 & 10.50 & $<.10$ & -- & $<.10$ & $<.50$ & 0.79 & 0.88 & $<.5$ & $M W 39 D(d)$ \\
\hline$<5.0$ & 19.50 & 0.004 & 23.4 & 17.80 & $<.10$ & -- & $<.10$ & $<.50$ & $<.5$ & $<.5$ & $<.5$ & MW39S \\
\hline$<5.0$ & 8.00 & 0.000 & 44.8 & 9.40 & $<.10$ & -- & $<.10$ & $<.50$ & $<.5$ & 0.48 & $<.5$ & MW39S \\
\hline 0.47 & -- & 0.000 & 34.65 & 9.04 & -- & 0.04 & $<.02$ & -- & 2.149 & -- & $<.02$ & MW39S \\
\hline$<5.0$ & 9.50 & 0.000 & 3.9 & 7.50 & $<.10$ & $\cdot-$ & $<.10$ & $<.50$ & 1.1 & 1.2 & $<.5$ & MW40D \\
\hline$<5.0$ & 11.5 & 0.002 & 8.5 & 7.40 & $<.10$ & -. & $<.10$ & $<.50$ & 1.4 & 1.6 & $<.5$ & MW $40 \mathrm{~S}$ \\
\hline$<5.0$ & 11.0 & 0.000 & 2.2 & 7.60 & $<.10$ & -- & $<.10$ & $<.50$ & 1.7 & 2 & $<.5$ & MW4ID \\
\hline$<5.0$ & 23.5 & 0.057 & 24.90 & 16.20 & $<.10$ & -- & $<.10$ & $<.50$ & $<.5$ & $<.5$ & $<.5$ & MW41S \\
\hline$<5.0$ & 10.00 & 0.007 & 12.20 & 3.30 & $<.10$ & -. & 0.1 & $<.50$ & $<.5$ & 0.18 & $<.5$ & MW43S \\
\hline$<5.0$ & -. & -. & 12.40 & 3.30 & $<.10$ & -- & $<.10$ & $<.50$ & $<.5$ & 0.18 & $<.5$ & MW43S(d) \\
\hline$<5.0$ & 462 & .. & 10.20 & 202.00 & $<.10$ & -- & $<.10$ & 1.4 & 0.82 & $<.5$ & $<.5$ & MW6IS \\
\hline$<5.0$ & -. & 0.082 & - & -- & -- & -. & -- & - &.- & -- & -- & MW61S \\
\hline$<5.0$ & 440 & 0.000 & 12.10 & 208.00 & $<.10$ & -. & 0.11 & 1.5 & 0.75 & $<.5$ & $<.5$ & MW61s \\
\hline 2.24 & -- & 0.000 & 8.56 & 150.63 & $-\cdot$ & 2.80 & $<.02$ & -. & $<.02$ & $\cdots$ & $<.02$ & MW6IS \\
\hline$<5.0$ & 8.00 & 0.002 & 0.53 & 7.80 & $<.10$ & -- & $<.10$ & $<.50$ & 2.4 & 2.6 & $<.5$ & MW62D \\
\hline$<5.0$ & 31.50 & 0.000 & 4.50 & 15.90 & $<.10$ & -- & $<.10$ & $<.50$ & $<.5$ & $<.5$ & $<.5$ & MW62S \\
\hline 1.17 & $-\cdot$ & 0.000 & -. & 11.84 & $-\cdot$ & 0.15 & 1.67 & - & 0.04 & -- & $<.02$ & MW62S \\
\hline$<5.0$ & 11.80 & 0.000 & 234.0 & 39.70 & $<.10$ & -. & 0.26 & $<.50$ & $<.5$ & $<.5$ & $<.5$ & MW64S \\
\hline$<5.0$ & -. & -- & 231.0 & 38.80 & $<.10$ & .. & 0.26 & $<.50$ & $<.5$ & $<.5$ & $<.5$ & MW64S(d) \\
\hline$<5.0$ & 8.00 & 0.004 & 2.50 & 11.90 & $<.10$ & -. & $<. \mathrm{i} 0$ & $<.50$ & 0.87 & 0.97 & $<.5$ & MW206D \\
\hline$<5.0$ & 10.60 & 0.000 & 1.60 & 13.60 & $<10$ & -- & $<10$ & $<.50$ & 0.69 & 0.76 & $<.5$ & MW206D \\
\hline$<5.0$ & -- & -- & 1.60 & 13.60 & $<.10$ & $-\cdot$ & $<.10$ & $<.50$ & 0.69 & 0.77 & $<.5$ & MW206D(d) \\
\hline$<5.0$ & 13.0 & 0.005 & 9.70 & 6.90 & $<.10$ & - & $<.10$ & $<.50$ & $<.5$ & 0.14 & $<.5$ & MW206M \\
\hline$<5.0$ & 14.50 & 0.006 & 9.20 & 9.00 & $<.10$ & -- & $<.10$ & $<.50$ & $<.5$ & 0.1 & $<.5$ & MW206M \\
\hline 0.87 & $-\cdot$ & 0.000 & 7.75 & 8.61 & $\cdots$ & 0.15 & $<.02$ & $\cdots$ & 0.87 & -- & $<.02$ & MW206M \\
\hline$<5.0$ & 6.60 & 0.000 & 1.20 & 8.70 & $<.10$ & -. & $<.10$ & $<.50$ & 2.4 & 2.7 & $<.5$ & MW226D \\
\hline$<5.0$ & 8.60 & 0.023 & 5.10 & 11.30 & $<.10$ & -- & $<.10$ & $<.50$ & 0.84 & 0.91 & $<.5$ & MW226M \\
\hline
\end{tabular}


Table 5. Ground-and surface-water quality data at the natural-attenuation study area, Dover Air Force Base, Kent County, Delaware, July - August 1995, May - July 1996, and August 1996, for inorganic constituents-Continued

\begin{tabular}{|c|c|c|c|c|c|c|c|c|c|c|}
\hline \multirow[b]{2}{*}{$\begin{array}{c}\text { Sample } \\
\text { identification } \\
\text { number }\end{array}$} & \multirow[b]{2}{*}{$\begin{array}{l}\text { Sample } \\
\text { date }\end{array}$} & \multirow[b]{2}{*}{ Time } & \multicolumn{4}{|c|}{ FIELD PARAMETERS } & \multicolumn{4}{|c|}{ MAJOR IONS } \\
\hline & & & $\begin{array}{l}\text { Spe- } \\
\text { cific } \\
\text { con- } \\
\text { duc- } \\
\text { tance } \\
(\mu \mathrm{S} / \\
\mathrm{cm})\end{array}$ & $\begin{array}{l}\mathrm{pH}, \\
\text { (stan- } \\
\text { dard } \\
\text { units) }\end{array}$ & $\begin{array}{l}\text { Tem- } \\
\text { pera- } \\
\text { ture } \\
\left({ }^{\circ} \mathrm{C}\right)\end{array}$ & $\begin{array}{l}\text { Oxy- } \\
\text { gen, } \\
\text { dis- } \\
\text { solved } \\
(\mathrm{mg} / \mathrm{L})\end{array}$ & $\begin{array}{l}\text { Hydro- } \\
\text { gen, } \\
\text { mean } \\
\text { value, } \\
(\mathrm{nmol} / \mathrm{L} \\
\text { as } \mathrm{H}_{2} \text { ) }\end{array}$ & $\begin{array}{l}\text { Cal- } \\
\text { cium } \\
\text { (mg/L } \\
\text { as } \\
\mathrm{Ca})\end{array}$ & $\begin{array}{c}\text { Mag- } \\
\text { nesium } \\
\text { (mg/L } \\
\text { as } \\
\mathrm{Mg} \text { ) }\end{array}$ & $\begin{array}{c}\text { So- } \\
\text { dium, } \\
(\mathrm{mg} / \mathrm{L}) \\
\text { as Na) }\end{array}$ \\
\hline \multicolumn{11}{|c|}{ GROUND-WATER SAMPLES--CONTINUED } \\
\hline MW226M & $06-06-96$ & 09:00 AM & 88 & 5.01 & 15.8 & 1.46 & -- & $<5.0$ & $<5.0$ & 11.3 \\
\hline MW226M & $08-03-96$ & -. & -- & 5.39 & 15.9 & 0.32 & 0.35 & 5.70 & 2.54 & 11.34 \\
\hline MW227D & $08-22-95$ & $09: 30 \mathrm{AM}$ & 86 & 5.03 & 15.7 & 1.35 & -- & $<5.0$ & $<5.0$ & 10.9 \\
\hline MW227D & $05-02-96$ & 01:30 PM & 81 & 4.54 & 15.2 & 2.21 & -- & $<5.0$ & $<5.0$ & 11.3 \\
\hline MW227D & $08-03-96$ & -- & -- & 5.08 & 16.5 & 3.03 & 0.90 & 4.91 & 2.14 & 9.68 \\
\hline MW227S & $05-06-96$ & $12: 30 \mathrm{PM}$ & 199 & 5.00 & 11.3 & 3.9 & -. & 12.5 & 11.2 & 20.9 \\
\hline MWD4B & $05-31-96$ & 03:00 PM & 148 & 5.75 & 15.1 & 5.1 & -- & 11.8 & 7.1 & 6.2 \\
\hline \multicolumn{11}{|c|}{ SURFACE-WATER SAMPLES } \\
\hline GSisw & $08-10-95$ & 10:15 AM & 72 & 5.56 & 25.9 & 3.2 & - & 6.4 & $<5.0$ & $<5.0$ \\
\hline GSisw & $05-23-96$ & 02:00 PM & 136 & 5.82 & 16.3 & 6.5 & -- & 10.2 & $<5.0$ & 10.7 \\
\hline GS2SW & 08-10-95 & $10: 45 \mathrm{AM}$ & 241 & 4.22 & 26.3 & 1.65 & -- & 19.9 & 5.4 & 5.2 \\
\hline GS2SW & $06-05-95$ & 03:30 PM & 127 & 6.16 & 19.5 & 7.0 & -- & 11.2 & $<5.0$ & 8.2 \\
\hline GS2SW(a) & $06-05-95$ & $-\cdot$ & -- & -- & -- & -- & - & 11.2 & $<5.0$ & 8.5 \\
\hline GS3SW & $08-17-95$ & $\therefore 00 \mathrm{PM}$ & 157 & 6.56 & 27.9 & 5.5 & - & 11.5 & 5.3 & 12 \\
\hline GS3SW & $05-22-96$ & 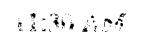 & $i 27$ & 6.28 & 20.9 & 5.9 & -- & 11 & $<5.0$ & 5.5 \\
\hline GS4SW & $08-16-95$ & $01: 00 \mathrm{rivi}$ & 828 & 6.56 & 27.6 & 5.0 & -- & 15.9 & 20 & 145 \\
\hline GS4SW(d) & $08-16-95$ & & -- & - & -- & -- & -- & 16.0 & 20.3 & 144 \\
\hline GS4SW & $05-20-96$ & 02:00 PM & 145 & 6.50 & 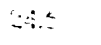 & - & -- & 5.7 & $<5.0$ & 9 \\
\hline \multicolumn{11}{|c|}{ QUALITY-ASSURANCE SAMPLES } \\
\hline Eq. Blank (1) & $07-27-95$ & -. & -. & -- & - & -- & -- & $<5.0$ & $<5.0$ & $<5.0$ \\
\hline Eq. Blank (2) & $08-02-95$ & -. & -- & -- & -. & -- & -- & $<5.0$ & $<5.0$ & $<5.0$ \\
\hline Eq. Blank (3) & $08-03-95$ & -- & $-\cdot$ & -- & -- & $-\cdot$ & -. & $<5.0$ & $<5.0$ & $<5.0$ \\
\hline Eq. Blank (4) & $08-09-95$ & -- & -. & -- & -. & -- & -- & $<5.0$ & $<5.0$ & $<5.0$ \\
\hline Eq. Blank (5) & $08-11-95$ & - & -. & $\cdots$ & -- & -- & $\cdots$ & $<5.0$ & $<5.0$ & $<5.0$ \\
\hline Eq. Blank (6) & $08-16-95$ & -- & -- & -- & - & - & -. & $<5.0$ & $<5.0$ & $<5.0$ \\
\hline Eq. Blank (7) & $08-16-95$ & -- & .. & -- & -- & - & -. & $<5.0$ & $<5.0$ & $<5.0$ \\
\hline Eq. Blank (8) & $08-18.95$ & -- & -- & - & -- & - & -- & $<5.0$ & $<5.0$ & $<5.0$ \\
\hline 与. Plank (9) & $08-22-95$ & - & -- & -. & -- & -- & -- & $<5.0$ & $<5.0$ & $<5.0$ \\
\hline Eq. Biank (10) & $05-01-400$ & -. & -- & -- & -- & .- &.. & $<5.0$ & $<5.0$ & $<5.0$ \\
\hline Eq. Blank (11) & $05-21-96$ & -- & -. & -- & -. & - & -- & $<5.0$ & $<5.0$ & $<5.0$ \\
\hline Eq. Blank (12) & $05-22-96$ & -. & -. & -- &.- & -- & -- & $<5.0$ & $<5.0$ & $<5.0$ \\
\hline Eq. Blank (13) & $05-30-96$ & -. & -- & -. & -. & - & -- & $<5.0$ & $<5.0$ & $<5.0$ \\
\hline Eq. Blank (14) & $06-05-96$ & -- & -- & $-\cdot$ & -- & -- & .. & $<5.0$ & $<5.0$ & $<5.0$ \\
\hline Eq. Blank (15) & $06-12-96$ & -. & -- & -- & .. & -- & -. & $<5.0$ & $<5.0$ & $<5.0$ \\
\hline
\end{tabular}




\begin{tabular}{|c|c|c|c|c|c|c|c|c|c|c|c|c|}
\hline \multicolumn{12}{|c|}{ MAJOR IONS } & \multirow[b]{2}{*}{$\begin{array}{c}\text { Sample } \\
\text { identification } \\
\text { number }\end{array}$} \\
\hline $\begin{array}{c}\text { Potas- } \\
\text { sium } \\
\text { (mg/ } \\
\text { L as } \\
\mathrm{K} \text { ) }\end{array}$ & $\begin{array}{l}\text { Alka- } \\
\text { linity, } \\
\text { field } \\
\text { (mg' } \\
\mathrm{L} \mathrm{as}^{\prime} \\
\mathrm{Ca} \\
\left.\mathrm{CO}_{3}\right)\end{array}$ & $\begin{array}{l}\text { Hydro- } \\
\text { gen } \\
\text { sul- } \\
\text { fide, } \\
\text { field } \\
\text { (mg/L } \\
\text { as } \\
\mathrm{H}_{2} \mathrm{~S} \text { ) }\end{array}$ & $\begin{array}{c}\text { Sulfate } \\
(\mathrm{mg} / \mathrm{L} \\
\text { as } \\
\left.\mathrm{SO}_{4}\right)\end{array}$ & $\begin{array}{l}\text { Chlo- } \\
\text { ride } \\
\text { (mg/L } \\
\text { as } \mathrm{Cl} \text { ) }\end{array}$ & $\begin{array}{l}\text { Fluo- } \\
\text { ride } \\
(\mathrm{mg} / \mathrm{L} \\
\text { as } \mathrm{F})\end{array}$ & $\begin{array}{l}\text { Bro- } \\
\text { mide, } \\
\text { (mg/ } \\
\mathrm{L} \text { as } \\
\mathrm{Br} \text { ) }\end{array}$ & $\begin{array}{l}\text { Nitro- } \\
\text { gen, } \\
\text { am- } \\
\text { monia } \\
(\mathrm{mg} / \mathrm{L} \\
\text { as } \\
\left.\mathrm{NH}_{4}\right)\end{array}$ & $\begin{array}{l}\text { Nitro- } \\
\text { gen, } \\
\text { kjel- } \\
\text { dahl } \\
\text { (mg/L } \\
\text { as N) }\end{array}$ & $\begin{array}{c}\text { Nit- } \\
\text { rate } \\
(\mathrm{mg} / \\
\mathrm{L} \text { as } \\
\mathrm{N})\end{array}$ & $\begin{array}{l}\mathrm{Ni}- \\
\text { trate, } \\
\text { plus } \\
\text { ni- } \\
\text { trite, } \\
\text { (mg/ } \\
\mathrm{L} \text { as } \\
\mathrm{N} \text { ) }\end{array}$ & $\begin{array}{c}\text { Phos- } \\
\text { phate, } \\
\text { ortho } \\
\text { (mg/ } \\
\mathrm{L} \mathrm{as} \\
\mathrm{PO}_{4} \text { ) }\end{array}$ & \\
\hline \multicolumn{13}{|c|}{ GROUND-WATER SAMPLES--CONTINUED } \\
\hline$<5.0$ & 9.00 & 0.015 & 5.70 & 12.00 & $<.10$ & -- & $<.10$ & $<.50$ & $<.5$ & 0.44 & $<.5$ & MW226M \\
\hline 1.28 & -- & 0.000 & 6.43 & 10.20 & -- & $-\cdot$ & $<.02$ & -- & 1.82 & -. & $<.02$ & MW226M \\
\hline$<5.0$ & 19.40 & 0.011 & 8.00 & 10.70 & $<.10$ & -- & $<.10$ & $<.50$ & $<.5$ & 0.46 & $<.5$ & MW227D \\
\hline$<5.0$ & 4.00 & 0.002 & 9.30 & 8.70 & $<.10$ & -- & $<.10$ & $<.50$ & $<.5$ & 0.4 & $<.5$ & MW227D \\
\hline 0.81 & -- & 0.004 & 6.39 & 4.97 & -- & -- & $<.02$ & -- & 1.42 & $-\cdot$ & $<.02$ & MW227D \\
\hline$<5.0$ & 14.00 & 0.028 & 56.60 & 34.80 & $<.10$ & -- & $<.10$ & $<.50$ & $<.5$ & $<.5$ & $<.5$ & MW227S \\
\hline$<5.0$ & 32.00 & 0.000 & 17.70 & 6.20 & $<.10$ & -- & $<.10$ & $<.50$ & 1.2 & 1.4 & $<.5$ & MWD4B \\
\hline \multicolumn{13}{|c|}{ SURFACE-WATER SAMPLES } \\
\hline$<5.0$ & 19.00 & 0.0076 & 6.10 & 2.00 & $<.10$ & -- & $<.10$ & 0.81 & $<.5$ & $<.5$ & $<.5$ & GSISW \\
\hline$<5.0$ & 26.50 & 0.003 & 16.10 & 8.30 & $<.10$ & -. & 1.1 & $<.50$ & - & -- & -- & GSISW \\
\hline$<5.0$ & -- & 0.007 & 115.0 & 4.00 & $<.10$ & -- & 0.32 & 0.96 & $<.5$ & $<.5$ & $<.5$ & GS2SW \\
\hline$<5.0$ & 28.50 & 0.003 & 12.60 & 6.3 & $<.10$ & $-\cdot$ & $<.10$ & $<.50$ & 0.85 & 0.95 & $<.5$ & GS2SW \\
\hline$<5.0$ & -- & -- & 12.60 & 6.0 & $<.10$ & -. & $<.10$ & $<.50$ & 0.86 & 0.95 & $<.5$ & GS2SW(d) \\
\hline$<5.0$ & 31.50 & 0.002 & 23.10 & 6 & $<.10$ & - & $<.10$ & $<.50$ & $<.5$ & 0.37 & $<.5$ & GS3SW \\
\hline$<5.0$ & 26.00 & 0.004 & 12.70 & 2.9 & $<.10$ & -- & 0.18 & $<.50$ & 2.4 & 2.8 & $<.5$ & GS3SW \\
\hline 6.9 & 36.00 & 0.000 & 44.3 & 238 & $<.10$ & -- & 0.12 & $<.50$ & $<.5$ & 0.29 & $<.5$ & GS4SW \\
\hline 6.9 & $-\cdot$ & -. & 43.9 & 236 & $<.10$ & -- & 0.11 & $<.50$ & $<.5$ & 0.26 & $<.5$ & GS4SW(d) \\
\hline$<5.0$ & 29.50 & 0.007 & 19.8 & 6.6 & $<.10$ & -- & $<.10$ & 0.51 & 0.98 & 1.1 & $<.5$ & GS4SW \\
\hline \multicolumn{13}{|c|}{ QUALITY-ASSURANCE SAMPLES } \\
\hline$<5.0$ & -- & -- & $<5.0$ & $<.50$ & $<.10$ & - & $<.10$ & $<.50$ & $<.5$ & $<.5$ & $<.5$ & Eq. Blank (1) \\
\hline$<5.0$ & -. & -- & $<5.0$ & $<.50$ & $<.10$ & - & $<.10$ & $<.50$ & $<.5$ & $<.5$ & $<.5$ & Eq. Blank (2) \\
\hline$<5.0$ & -- & -- & $<5.0$ & $<.50$ & $<.10$ & - & $<.10$ & $<.50$ & $<.5$ & $<.5$ & $<.5$ & Eq. Blank (3) \\
\hline$<5.0$ & -- & - & $<5.0$ & $<.50$ & $<.10$ & -- & $<.10$ & $<.50$ & $<.5$ & $<.5$ & $<.5$ & Eq. Blank (4) \\
\hline$<5.0$ & -- & $-\cdot$ & $<5.0$ & 0.62 & $<.10$ & $\cdots$ & $<.10$ & $<.50$ & $<.5$ & $<.5$ & $<.5$ & Eq. Blank (5) \\
\hline$<5.0$ & -- & -- & $<5.0$ & $<.50$ & $<.10$ & -- & $<.10$ & $<.50$ & $<.5$ & $<.5$ & $<.5$ & Eq. Blank (6) \\
\hline$<5.0$ & -- & -- & 0.82 & $<.50$ & $<.10$ & -. & $<.10$ & $<.50$ & $<.5$ & $<.5$ & $<.5$ & Eq. Blank (7) \\
\hline$<5.0$ & $-\cdot$ & -- & $<5.0$ & $<.50$ & $<.10$ & -- & $<.10$ & $<.50$ & $<.5$ & $<.5$ & $<.5$ & Eq. Blank (8) \\
\hline$<5.0$ & $-\cdot$ & -- & $<5.0$ & $<.50$ & $<.10$ & -- & $<.10$ & $<.50$ & $<.5$ & 0.50 & $<.5$ & Eq. Blank (9) \\
\hline$<5.0$ & $-\cdot$ & -- & $<5.0$ & $<.50$ & $<.10$ & -- & $<.10$ & $<.50$ & $<.5$ & $<.5$ & $<.5$ & Eq. Blank (10) \\
\hline$<5.0$ & -. & -- & $<5.0$ & $<.50$ & $<.10$ & -. & $<.10$ & $<.50$ & $<.5$ & $<.5$ & $<.5$ & Eq. Blank (11) \\
\hline$<5.0$ & .. & -- & $<5.0$ & $<.50$ & $<.10$ & -- & $<.10$ & $<.50$ & $<.5$ & $<.5$ & $<.5$ & Eq. Blank (12) \\
\hline$<5.0$ & -- & .. & $<5.0$ & $<.50$ & $<.10$ & $-\cdot$ & $<.10$ & $<.50$ & $<.5$ & $<.5$ & $<.5$ & Eq. Blank (13) \\
\hline$<5.0$ & -- & -. & $<5.0$ & $<.50$ & $<.10$ & -- & $<.10$ & $<.50$ & $<.5$ & $<.5$ & $<.5$ & Eq. Blank (14) \\
\hline$<5.0$ & -. & -- & $<5.0$ & $<.50$ & $<.10$ & -- & $<.10$ & $<.50$ & $<.5$ & $<.5$ & $<.5$ & Eq. Blank (15) \\
\hline
\end{tabular}


Table 5. Ground-and surface-water quality data at the natural-attenuation study area, Dover Air Force Base, Kent County, Delaware, July-August 1995, May - July 1996, and August 1996, for inorganic constituents-Continued

\begin{tabular}{|c|c|c|c|c|c|c|c|c|c|c|}
\hline \multirow[b]{2}{*}{$\begin{array}{c}\text { Sample } \\
\text { identification } \\
\text { number }\end{array}$} & \multirow[b]{2}{*}{$\begin{array}{c}\text { Sample } \\
\text { date }\end{array}$} & \multirow[b]{2}{*}{ Time } & \multicolumn{4}{|c|}{ FIELD PARAMETERS } & \multicolumn{4}{|c|}{ MAJOR IONS } \\
\hline & & & $\begin{array}{l}\text { Spe- } \\
\text { cific } \\
\text { con- } \\
\text { duc- } \\
\text { tance } \\
(\mu \mathrm{S} / \\
\mathrm{cm})\end{array}$ & $\begin{array}{c}\mathrm{pH}, \\
\text { (stan- } \\
\text { dard } \\
\text { units) }\end{array}$ & $\begin{array}{l}\text { Tem- } \\
\text { pera- } \\
\text { ture } \\
\left({ }^{\circ} \mathrm{C}\right)\end{array}$ & $\begin{array}{l}\text { Oxy- } \\
\text { gen, } \\
\text { dis- } \\
\text { solved } \\
(\mathrm{mg} / \mathrm{L})\end{array}$ & $\begin{array}{l}\text { Hydro- } \\
\text { gen, } \\
\text { mean } \\
\text { value, } \\
\text { (nmol/L } \\
\text { as } \mathrm{H}_{2} \text { ) }\end{array}$ & $\begin{array}{c}\text { Cal- } \\
\text { cium } \\
\text { (mg/L } \\
\text { as } \\
\text { Ca) }\end{array}$ & $\begin{array}{c}\text { Mag- } \\
\text { nesium } \\
\text { (mg/L } \\
\text { as } \\
\mathrm{Mg} \text { ) }\end{array}$ & $\begin{array}{l}\text { So- } \\
\text { dium, } \\
\text { (mg/L) } \\
\text { as } \mathrm{Na})\end{array}$ \\
\hline \multicolumn{11}{|c|}{ QUALITY-ASSURANCE SAMPLES --CONTINUED } \\
\hline Eq. Blank (16) & $06-13-96$ & -- & - & -. & -- & -- & -- & $<5.0$ & $<5.0$ & $<5.0$ \\
\hline Eq. Blank (17) & $06-14-96$ & -- & - & -- & -- & -- & -- & $<5.0$ & $<5.0$ & $<5.0$ \\
\hline
\end{tabular}




\begin{tabular}{|c|c|c|c|c|c|c|c|c|c|c|c|c|}
\hline \multicolumn{12}{|c|}{ MAJOR IONS } & \multirow[b]{2}{*}{$\begin{array}{c}\text { Sample } \\
\text { identification } \\
\text { number }\end{array}$} \\
\hline $\begin{array}{c}\text { Potas- } \\
\text { sium } \\
\text { (mg/ } \\
\text { L as } \\
\mathrm{K} \text { ) }\end{array}$ & $\begin{array}{c}\text { Alka- } \\
\text { linity, } \\
\text { field } \\
(\mathrm{mg} / \\
\mathrm{L} \text { as } \\
\mathrm{Ca} \\
\left.\mathrm{CO}_{3}\right)\end{array}$ & $\begin{array}{l}\text { Hydro- } \\
\text { gen } \\
\text { sul- } \\
\text { fide, } \\
\text { field } \\
\text { (mg/L } \\
\text { as } \\
\mathrm{H}_{2} \mathrm{~S} \text { ) }\end{array}$ & 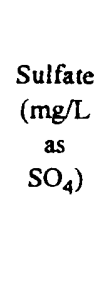 & $\begin{array}{l}\text { Chlo- } \\
\text { ride } \\
(\mathrm{mg} / \mathrm{L} \\
\text { as } \mathrm{Cl})\end{array}$ & $\begin{array}{l}\text { Fluo- } \\
\text { ride } \\
(\mathrm{mg} / \mathrm{L} \\
\text { as } \mathrm{F})\end{array}$ & $\begin{array}{c}\text { Bro- } \\
\text { mide, } \\
\text { (mg/ } \\
\mathrm{L} \text { as } \\
\mathrm{Br} \text { ) }\end{array}$ & $\begin{array}{c}\text { Nitro- } \\
\text { gen, } \\
\text { am- } \\
\text { monia } \\
(\mathrm{mg} / \mathrm{L} \\
\text { as } \\
\left.\mathrm{NH}_{4}\right)\end{array}$ & $\begin{array}{l}\text { Nitro- } \\
\text { gen, } \\
\text { kjel- } \\
\text { dahl } \\
\text { (mg/L } \\
\text { as } N \text { ) }\end{array}$ & $\begin{array}{l}\text { Nit- } \\
\text { rate } \\
(\mathrm{mg} / \\
\mathrm{L} \text { as } \\
\mathrm{N})\end{array}$ & $\begin{array}{c}\text { Ni- } \\
\text { trate, } \\
\text { plus } \\
\text { ni- } \\
\text { trite, } \\
\text { (mg/ } \\
\mathrm{L} \text { as } \\
\mathrm{N})\end{array}$ & $\begin{array}{l}\text { Phos- } \\
\text { phate, } \\
\text { ortho } \\
\text { (mg/ } \\
\mathrm{L} \text { as } \\
\mathrm{PO}_{4} \text { ) }\end{array}$ & \\
\hline \multicolumn{13}{|c|}{ QUALITY-ASSURANCE SAMPLES --CONTINUED } \\
\hline$<5.0$ &.- & -- & $<5.0$ & 0.53 & $<.10$ & -- & $<.10$ & $<.50$ & $<.5$ & $<.5$ & $<.5$ & Eq. Blank (16) \\
\hline$<5.0$ & -- & -- & $<5.0$ & $<.50$ & $<.10$ & -- & $<.10$ & $<.50$ & $<.5$ & $<.5$ & $<.5$ & Eq. Blank (17) \\
\hline
\end{tabular}


Table 5. Ground-and surface-water quality data at the natural-attenuation study area, Dover Air Force Base, Kent County, Delaware, July - August 1995, May-July 1996, and August 1996, for inorganic

constituents

[Locations of sample sites shown on figures 5 and $6 ; \mathrm{mg} / \mathrm{L}$, milligrams per liter; $\mu \mathrm{g} / \mathrm{L}$, micrograms per liter; --, no data; quality-assurance samples are at end of table; (d), quality control duplicate samples; Eq. Blank, equipment blank; constituents analyzed in field $\left(\mathrm{Fe}^{+2}+\mathrm{Fe}^{+3}\right.$ and $\left.\mathrm{Fe} \mathrm{e}^{+2}\right)$ were analyzed by USGS personnel; all others were analyzed by a contract laboratory]

\begin{tabular}{|c|c|c|c|c|c|c|c|c|c|c|}
\hline \multirow[b]{2}{*}{$\begin{array}{l}\text { Sample } \\
\text { ident- } \\
\text { ification } \\
\text { number }\end{array}$} & \multicolumn{9}{|c|}{ METALS } & \multirow[b]{2}{*}{$\begin{array}{c}\text { Iron, } \\
\text { field, } \\
(\mathrm{mg} / \mathrm{L} \text { as } \\
\mathrm{Fe}^{+2}+ \\
\left.\mathrm{Fe}^{+3}\right)\end{array}$} \\
\hline & $\begin{array}{c}\text { Sample } \\
\text { date }\end{array}$ & $\begin{array}{l}\text { Alum- } \\
\text { inum, } \\
(\mu \mathrm{g} / \mathrm{L} \text { as } \\
\mathrm{Al})\end{array}$ & $\begin{array}{c}\text { Anti- } \\
\text { mony, } \\
(\mu \mathrm{g} / \mathrm{L} \text { as } \\
\mathrm{Sb})\end{array}$ & $\begin{array}{c}\text { Arsenic, } \\
(\mu \mathrm{g} / \mathrm{L} \text { as } \\
\text { As) }\end{array}$ & $\begin{array}{c}\text { Barium, } \\
\text { ( } \mu \mathrm{g} / \mathrm{L} \text { as } \\
\mathrm{Ba})\end{array}$ & $\begin{array}{l}\text { Cad- } \\
\text { mium, } \\
(\mu \mathrm{g} / \mathrm{L} \text { as } \\
\text { Cd })\end{array}$ & $\begin{array}{c}\text { Chro- } \\
\text { mium, } \\
(\mu \mathrm{g} / \mathrm{L} \text { as } \\
\mathrm{Cr})\end{array}$ & $\begin{array}{c}\text { Cobalt, } \\
(\mu \mathrm{g} / \mathrm{L} \text { as } \\
\text { Co })\end{array}$ & $\begin{array}{c}\text { Copper, } \\
(\mu g / \mathrm{L} \text { as } \\
\mathrm{Cu})\end{array}$ & \\
\hline \multicolumn{11}{|c|}{ GROUND-WATER SAMPLES } \\
\hline DM102D & $06-06-96$ & $<0.20$ & $<0.20$ & $<0.30$ & $<0.10$ & $<0.005$ & $<0.030$ & $<0.040$ & $<0.030$ & -. \\
\hline DM107D & $05-02-96$ & $<.20$ & $<.20$ & $<.30$ & $<.10$ & $<.005$ & $<.030$ & $<.040$ & $<.030$ & 0.48 \\
\hline DM107S & $05-01-96$ & $<.20$ & $<.20$ & $<.30$ & $<.10$ & $<.005$ & $<.030$ & $<.040$ & $<.030$ & 0.01 \\
\hline DM108D & $05-13-96$ & $<.20$ & $<.20$ & $<.30$ & $<.10$ & $<.005$ & $<.030$ & $<.040$ & $<.030$ & 0.06 \\
\hline DM108S & $05-01-96$ & $<.20$ & $<.20$ & $<.30$ & $<.10$ & $<.005$ & $<.030$ & $<.040$ & $<.030$ & 0.25 \\
\hline DM110D & $06-13-96$ & $<.20$ & $<.20$ & $<.30$ & $<.10$ & $<.005$ & $<.030$ & $<.040$ & $<.030$ & 0.35 \\
\hline DM110S & $08-21-95$ & $<.20$ & $<.20$ & $<.30$ & $<.10$ & $<.005$ & $<.030$ & 0.090 & $<.030$ & 36.48 \\
\hline DM110S & $06-13-96$ & $<.20$ & $<.20$ & $<.30$ & $<.10$ & $<.005$ & $<.030$ & 0.10 & $<.030$ & 20.08 \\
\hline DM113D & $06-04-96$ & $<.20$ & $<.20$ & $<.30$ & $<.10$ & $<.005$ & $<.030$ & $<.040$ & $<.030$ & 0.00 \\
\hline DM113S & $08-08-95$ & $<.20$ & $<.20$ & $<.30$ & $<.10$ & $<.005$ & $<.030$ & $<.040$ & $<.030$ & 0.01 \\
\hline DM117D & $05-21-96$ & $<.20$ & $<.20$ & $<.30$ & $<.10$ & $<.005$ & $<.030$ & $<.040$ & $<.030$ & 17.00 \\
\hline GSID & $08-11-95$ & $<.20$ & $<.20$ & $<.30$ & $<.10$ & $<.005$ & $<.030$ & $<.040$ & $<.030$ & 12.37 \\
\hline GSID & $05-23-96$ & $<.20$ & $<.20$ & $<.30$ & $<.10$ & $<.005$ & $<.030$ & $<.040$ & $<.030$ & 17.81 \\
\hline GSIM & $08-10-95$ & $<.20$ & $<.20$ & $<.30$ & 0.11 & $<.005$ & $<.030$ & $<.040$ & $<.030$ & 15.84 \\
\hline GSIM & $05-23-96$ & $<.20$ & $<.20$ & $<.30$ & $<.10$ & $<.005$ & $<.030$ & $<.040$ & $<.030$ & 1.07 \\
\hline GS1S & $08-10-95$ & $<.20$ & $<.20$ & $<.30$ & $<.10$ & $<.005$ & $<.030$ & $<.040$ & $<.030$ & 12.60 \\
\hline GSIS & $05-23-96$ & $<.20$ & $<.20$ & $<.30$ & $<.10$ & $<.005$ & $<.030$ & $<.040$ & $<.030$ & 3.76 \\
\hline GS2D & $08-09-95$ & 0.20 & $<.20$ & $<.30$ & 0.11 & $<.005$ & $<.030$ & $<.040$ & $<.030$ & 6.12 \\
\hline GS2D & $06-05-96$ & $<.20$ & $<.20$ & $<.30$ & $<.10$ & $<.005$ & $<.030$ & $<.040$ & $<.030$ & 5.81 \\
\hline GS2M & 08-09-95 & 0.30 & $<.20$ & $<.30$ & $<.10$ & $<.005$ & $<.030$ & $<.040$ & $<.030$ & 6.72 \\
\hline GS2M & $06-05-96$ & $<.20$ & $<.20$ & $<.30$ & $<.10$ & $<.005$ & $<.030$ & $<.040$ & $<.030$ & 7.96 \\
\hline GS2S & $08-09-95$ & $<.20$ & $<.20$ & $<.30$ & $<.10$ & $<.005$ & $<.030$ & $<.040$ & $<.030$ & 8.02 \\
\hline GS2S & $06-05-96$ & $<.20$ & $<.20$ & $<.30$ & $<.10$ & $<.005$ & $<.030$ & $<.040$ & $<.030$ & 6.99 \\
\hline GS2S(d) & $06-05-96$ & $<.20$ & $<.20$ & -- & $<.10$ & $<.005$ & $<.030$ & $<.040$ & $<.030$ & $-\cdot$ \\
\hline GS3M & $08-18-95$ & $<.20$ & $<.20$ & $<.30$ & $<.10$ & $<.005$ & $<.030$ & $<.040$ & $<.030$ & 0.00 \\
\hline GS3M & $05-22-96$ & $<.20$ & $<.20$ & $<.30$ & $<.10$ & $<.005$ & $<.030$ & $<.040$ & $<.030$ & 0.00 \\
\hline$G S 3 M(d)$ & $05-22-96$ & $<.20$ & $<.20$ & $-\cdot$ & $<.10$ & $<.005$ & $<.030$ & $<.040$ & $<.030$ & -- \\
\hline GS3S & $08-17-95$ & $<.20$ & $<.20$ & $<.30$ & 0.12 & $<.005$ & $<.030$ & $<.040$ & $<.030$ & 39.00 \\
\hline GS3S & $05-22-96$ & $<.20$ & $<.20$ & $<.30$ & $<.10$ & $<.005$ & $<.030$ & $<.040$ & $<.030$ & 16.16 \\
\hline GS4D & $08-17-95$ & $<.20$ & $<.20$ & $<.30$ & $<.10$ & $<.005$ & $<.030$ & $<.040$ & $<.030$ & 3.35 \\
\hline GS4D & $05-21-96$ & $<.20$ & $<.20$ & $<30$ & $<.10$ & $<.005$ & $<.030$ & $<.040$ & $<.030$ & 4.75 \\
\hline GS4M & $08-16-95$ & $<.20$ & $<.20$ & $<.30$ & $<.10$ & $<.005$ & $<.030$ & $<.040$ & $<.030$ & 5.92 \\
\hline GS4M & $05-21-96$ & $<.20$ & $<.20$ & $<.30$ & $<.10$ & $<.005$ & $<.030$ & $<.040$ & $<.030$ & 8.96 \\
\hline
\end{tabular}




\begin{tabular}{|c|c|c|c|c|c|c|c|c|c|c|c|}
\hline \multicolumn{11}{|c|}{ METALS } & \multirow[b]{2}{*}{$\begin{array}{l}\text { Sample } \\
\text { ident- } \\
\text { ification } \\
\text { number }\end{array}$} \\
\hline $\begin{array}{l}\text { Iron, } \\
\text { field, } \\
(\mathrm{mg} / \mathrm{L} \\
\text { as } \\
\left.\mathrm{Fe}^{+2}\right)\end{array}$ & $\begin{array}{l}\text { Lead, } \\
(\mu \mathrm{g} / \mathrm{L} \\
\text { as } \mathrm{Pb})\end{array}$ & $\begin{array}{l}\text { Mang- } \\
\text { anese, } \\
(\mu g / L \\
\text { as } M n)\end{array}$ & $\begin{array}{c}\text { Merc- } \\
\text { ury, } \\
(\mu g / L \\
\text { as } \mathrm{Hg})\end{array}$ & $\begin{array}{l}\text { Moly- } \\
\text { bden- } \\
\text { um( } \mu \mathrm{g} / \\
\mathrm{L} \text { as } \\
\mathrm{Mo})\end{array}$ & $\begin{array}{l}\text { Nickel, } \\
(\mu \mathrm{g} / \mathrm{L} \\
\text { as } \mathrm{Ni})\end{array}$ & $\begin{array}{c}\text { Selen- } \\
\text { ium, } \\
(\mu \mathrm{g} / \mathrm{L} \\
\text { as Se) }\end{array}$ & $\begin{array}{c}\text { Silver, } \\
(\mu \mathrm{g} / \mathrm{L} \\
\text { as } \mathrm{Ag})\end{array}$ & $\begin{array}{l}\text { Thal- } \\
\text { lium, } \\
(\mu g / L \\
\text { as } T 1)\end{array}$ & $\begin{array}{l}\text { Vana- } \\
\text { dium, } \\
\text { ( } \mu g / L \\
\text { as } V \text { ) }\end{array}$ & $\begin{array}{l}\text { Zinc, } \\
(\mu g / L \\
\text { as Z) }\end{array}$ & \\
\hline \multicolumn{12}{|c|}{ GROUND-WATER SAMPLES-CONTINUED } \\
\hline 1.36 & $<0.20$ & 0.17 & $<0.002$ & $<0.040$ & $<0.040$ & $<0.40$ & $<0.040$ & $<5.0$ & $<0.040$ & 0.019 & DM102D \\
\hline 0.52 & $<.20$ & 0.017 & $<.002$ & $<.040$ & $<.040$ & $<.40$ & $<.040$ & $<5.0$ & $<.040$ & 0.015 & DM107D \\
\hline 0.05 & $<.20$ & $<0.010$ & $<.002$ & $<.040$ & $<.040$ & $<.40$ & $<.040$ & $<5.0$ & $<.040$ & $<0.010$ & DM107S \\
\hline 0.05 & $<.20$ & 0.013 & $<.002$ & $<.040$ & $<.040$ & $<.40$ & $<.040$ & $<5.0$ & $<.040$ & 0.013 & DM108D \\
\hline 0.24 & $<.20$ & 0.036 & $<.002$ & $<.040$ & $<.040$ & $<.40$ & $<.040$ & $<5.0$ & $<.040$ & 0.033 & DM108S \\
\hline 0.34 & $<.20$ & 0.026 & $<.002$ & $<.040$ & $<.040$ & $<.40$ & $<.040$ & $<5.0$ & $<.040$ & 0.025 & DM110D \\
\hline 12.9 & $<.20$ & 1.4 & $<.002$ & $<.040$ & 0.041 & $<.40$ & $<.040$ & $<5.0$ & $<.040$ & $<.010$ & DMIIOS \\
\hline 19.68 & $<.20$ & 1.4 & $<.002$ & $<.040$ & 0.055 & $<.40$ & $<.040$ & $<5.0$ & $<.040$ & $<.010$ & DMIIOS \\
\hline 0.02 & $<.20$ & $<.010$ & $<.002$ & $<.040$ & $<.040$ & $<.40$ & $<.040$ & $<5.0$ & $<.040$ & 0.011 & DM113D \\
\hline 0.02 & $<.20$ & 0.050 & $<.002$ & $<.040$ & $<.040$ & $<.40$ & $<.040$ & $<5.0$ & $<.040$ & $<.010$ & DM113S \\
\hline 15.80 & $<.20$ & 0.065 & $<.002$ & $<.040$ & $<.040$ & $<.40$ & $<.040$ & $<5.0$ & $<.040$ & $<.010$ & DM117D \\
\hline 8.09 & $<.20$ & 0.74 & $<.002$ & $<.040$ & 0.064 & $<.40$ & $<.040$ & $<5.0$ & $<.040$ & $<.010$ & GSID \\
\hline 8.41 & $<.20$ & 0.88 & $<.002$ & $<.040$ & $<.040$ & $<.40$ & $<.040$ & $<5.0$ & $<.040$ & $<.010$ & GSID \\
\hline 10.03 & $<.20$ & 0.22 & $<.002$ & $<.040$ & $<.040$ & $<.40$ & $<.040$ & $<5.0$ & $<.040$ & $<.010$ & GSIM \\
\hline 1.09 & $<.20$ & 0.022 & $<.002$ & $<.040$ & $<.040$ & $<.40$ & $<.040$ & $<5.0$ & $<.040$ & $<.010$ & GSIM \\
\hline 9.11 & $<.20$ & 0.10 & $<.002$ & $<.040$ & $<.040$ & $<.40$ & $<.040$ & $<5.0$ & $<.040$ & 0.014 & GSis \\
\hline 3.12 & $<.20$ & 0.029 & $<.002$ & $<.040$ & $<.040$ & $<.40$ & $<.040$ & $<5.0$ & $<.040$ & $<.010$ & GSIS \\
\hline 2.62 & $<.20$ & 0.064 & $<.002$ & $<.040$ & 0.043 & $<.40$ & $<.040$ & $<5.0$ & $<.040$ & 0.025 & GS2D \\
\hline 4.32 & $<.20$ & 0.048 & $<.002$ & $<.040$ & $<.040$ & $<.40$ & $<.040$ & $<5.0$ & $<.040$ & 0.023 & GS2D \\
\hline 4.25 & $<.20$ & 0.052 & $<.002$ & $<.040$ & 0.040 & $<.40$ & $<.040$ & $<5.0$ & $<.040$ & 0.035 & GS2M \\
\hline 7.76 & $<.20$ & 0.052 & $<.002$ & $<.040$ & $<.040$ & $<.40$ & $<.040$ & $<5.0$ & $<.040$ & 0.027 & GS2M \\
\hline 5.00 & $<.20$ & 0.063 & $<.002$ & $<.040$ & $<.040$ & $<.40$ & $<.040$ & $<5.0$ & $<.040$ & $<.010$ & GS2S \\
\hline 6.68 & $<.20$ & 0.059 & $<.002$ & $<.040$ & $<.040$ & $<.40$ & $<.040$ & $<5.0$ & $<.040$ & $<.010$ & GS2S \\
\hline -- & $<.20$ & 0.035 & $<.002$ & $<.040$ & $<.040$ & $<.40$ & $<.040$ & $<5.0$ & $<.040$ & $<.010$ & GS2S(d) \\
\hline 0.00 & $<.20$ & $<.010$ & $<.002$ & $<.040$ & $<.040$ & $<.40$ & $<.040$ & $<5.0$ & $<.040$ & 0.024 & GS3M \\
\hline 0.00 & $<.20$ & $<.010$ & $<.002$ & $<.040$ & $<.040$ & $<.40$ & $<.040$ & $<5.0$ & $<.040$ & 0.033 & GS3M \\
\hline -- & $<.20$ & $<.010$ & $<.002$ & $<.040$ & $<.040$ & $<.40$ & $<.040$ & $<5.0$ & $<.040$ & 0.024 & GS3M(d) \\
\hline 33.90 & $<.20$ & 0.47 & $<.002$ & $<.040$ & $<.040$ & $<.40$ & $<.040$ & $<5.0$ & $<.040$ & $<.010$ & GS3S \\
\hline 12.56 & $<.20$ & 0.26 & $<.002$ & $<.040$ & $<.040$ & $<.40$ & $<.040$ & $<5.0$ & $<.040$ & $<.010$ & GS3S \\
\hline 3.34 & $<.20$ & 0.092 & $<.002$ & $<.040$ & $<.040$ & $<.40$ & $<.040$ & $<5.0$ & $<.040$ & $<.010$ & GS4D \\
\hline 1.70 & $<.20$ & 0.081 & $<.002$ & $<.040$ & $<.040$ & $<.40$ & $<.040$ & $<5.0$ & $<.040$ & $<.010$ & GS4D \\
\hline 5.31 & $<.20$ & 0.050 & $<.002$ & $<.040$ & $<.040$ & $<.40$ & $<.040$ & $<5.0$ & $<.040$ & $<.010$ & GS4M \\
\hline 1.77 & $<.20$ & 0.053 & $<.002$ & $<.040$ & $<.040$ & $<.40$ & $<.040$ & $<5.0$ & $<.040$ & $<.010$ & GS4M \\
\hline
\end{tabular}


Table 5. Ground-and surface-water quality data at the natural-attenuation study area, Dover Air Force Base, Kent County, Delaware, July-August 1995, May-July 1996, and August 1996, for inorganic constituents-Continued

\begin{tabular}{|c|c|c|c|c|c|c|c|c|c|c|}
\hline \multirow[b]{2}{*}{$\begin{array}{l}\text { Sample } \\
\text { ident- } \\
\text { ification } \\
\text { number }\end{array}$} & \multicolumn{9}{|c|}{ ME'TALS } & \multirow[b]{2}{*}{$\begin{array}{c}\text { Iron, } \\
\text { field, } \\
(\mathrm{mg} / \mathrm{L} \text { as } \\
\mathrm{Fe}^{+2}+ \\
\left.\mathrm{Fe}^{+3}\right)\end{array}$} \\
\hline & $\begin{array}{l}\text { Sample } \\
\text { date }\end{array}$ & $\begin{array}{l}\text { Alum- } \\
\text { inum, } \\
(\mu \mathrm{g} / \mathrm{L} \text { as } \\
\mathrm{Al})\end{array}$ & $\begin{array}{c}\text { Anti- } \\
\text { mony, } \\
(\mu \mathrm{g} / \mathrm{L} \text { as } \\
\mathrm{Sb})\end{array}$ & $\begin{array}{l}\text { Arsenic, } \\
(\mu g / L \text { as } \\
\text { As) }\end{array}$ & $\begin{array}{c}\text { Barium, } \\
(\mu \mathrm{g} / \mathrm{L} \text { as } \\
\mathrm{Ba})\end{array}$ & $\begin{array}{l}\text { Cad- } \\
\text { mium, } \\
(\mu \mathrm{g} / \mathrm{L} \text { as } \\
\text { Cd })\end{array}$ & $\begin{array}{c}\text { Chro- } \\
\text { mium, } \\
(\mu \mathrm{g} / \mathrm{L} \text { as } \\
\mathrm{Cr})\end{array}$ & $\begin{array}{c}\text { Cobalt, } \\
\text { ( } \mu \mathrm{g} / \mathrm{L} \text { as } \\
\text { Co) }\end{array}$ & $\begin{array}{c}\text { Copper, } \\
(\mu \mathrm{g} / \mathrm{L} \text { as } \\
\mathrm{Cu})\end{array}$ & \\
\hline \multicolumn{11}{|c|}{ GROUND-WATER SAMPLES--CONTINUED } \\
\hline GS4S & $08-16-95$ & $<.20$ & $<.20$ & $<.30$ & $<.10$ & $<.005$ & $<.030$ & $<.040$ & $<.030$ & 6.47 \\
\hline GS4S & $05-20-95$ & $<.20$ & $<.20$ & $<.30$ & $<10$ & $<.005$ & $<.030$ & $<.040$ & $<.030$ & 7.29 \\
\hline GSCP3D & $06-11-96$ & $<.20$ & $<.20$ & $<.30$ & $<.10$ & $<.005$ & $<.030$ & $<.040$ & $<.030$ & 0.04 \\
\hline GSCP3M & $06-11-96$ & $<.20$ & $<.20$ & $<.30$ & $<.10$ & $<.005$ & $<.030$ & $<.040$ & $<.030$ & 10.12 \\
\hline GSCP4M & $06-11-96$ & $<.20$ & $<.20$ & $<.30$ & $<.10$ & $<.005$ & $<.030$ & $<.040$ & $<.030$ & 4.54 \\
\hline GSCP5M & $06-07-96$ & $<.20$ & $<.20$ & $<.30$ & $<.10$ & $<.005$ & $<.030$ & $<.040$ & $<.030$ & 4.72 \\
\hline GSCP5M(d) & $06-07-96$ & $<.20$ & $<.20$ & & $<.10$ & $<.005$ & $<.030$ & $<.040$ & $<.030$ & -- \\
\hline GSCP6D & $06-10-96$ & $<.20$ & $<.20$ & $<.30$ & $<.10$ & $<.005$ & $<.030$ & $<.040$ & $<.030$ & 6.64 \\
\hline GSCP8 & $07-11-96$ & $<.20$ & $<.20$ & $<.30$ & $<.10$ & $<.005$ & $<.030$ & $<.040$ & $<.030$ & 2.09 \\
\hline GSCP9S & $06-12-96$ & $<.20$ & $<20$ & $<.30$ & $<.10$ & 0.0053 & $<.030$ & $<.040$ & $<.030$ & 0.31 \\
\hline MW11 & $08-22-95$ & $<.20$ & $<.20$ & $<.30$ & $<.10$ & $<.005$ & $<.030$ & $<.040$ & $<.030$ & 1.20 \\
\hline MW18 & $08-03-95$ & $<.20$ & $<.20$ & $<.30$ & $<.10$ & $<.005$ & $<.030$ & $<.040$ & $<.030$ & 0.00 \\
\hline MW . 9 & $08-08-95$ & $<.20$ & $<.20$ & $<.30$ & $<.10$ & $<.005$ & $<.030$ & $<.040$ & $<.030$ & 2.05 \\
\hline MW19 & $08-08-95$ & $<.20$ & $<.20$ & $<.30$ & $<.10$ & $<.005$ & $<.030$ & $<.040$ & $<.030$ & 0.28 \\
\hline MW19 & $05-17-96$ & $<.20$ & $<.20$ & $<.30$ & $<.10$ & $<.005$ & $<.030$ & $<.040$ & $<.030$ & 1.45 \\
\hline MW20 & $07-28-95$ & $<.20$ & $<.20$ & $<.30$ & $<.10$ & $<.005$ & $<.030$ & $<.040$ & $<.030$ & 3.30 \\
\hline MW206D & $08-01-95$ & $<.20$ & $<.20$ & $<.30$ & 0.10 & $<.005$ & $<.030$ & $<.040$ & $<.030$ & 0.01 \\
\hline MW206D & $05-31-96$ & $<.20$ & $<.20$ & $<.30$ & $<.10$ & $<.005$ & $<.030$ & $<.040$ & $<.030$ & 0.01 \\
\hline MW206D(d) & $05-31-96$ & $<.20$ & $<.20$ & - & $<.10$ & $<.005$ & $<.030$ & $<.040$ & $<.030$ & -- \\
\hline MW206M & $07-08-95$ & $<.20$ & $<.20$ & $<.30$ & $<.10$ & $<.005$ & $<.030$ & $<.040$ & $<.030$ & 0.33 \\
\hline MW206M & $05-30-96$ & $<.20$ & $<.20$ & $<.30$ & $<.10$ & $<.005$ & $<.030$ & $<.040$ & $<.030$ & 1.04 \\
\hline MW21 & $07-25-95$ & $<.20$ & $<.20$ & $<.30$ & $<.10$ & $<.005$ & $<.030$ & $<.040$ & $<.030$ & 2.35 \\
\hline MW226D & $08-02-95$ & $<.20$ & $<.20$ & $<.30$ & $<.10$ & $<.005$ & $<.030$ & $<.040$ & $<.030$ & 0.00 \\
\hline MW226M & $08-02-95$ & $<.20$ & $<.20$ & $<.30$ & $<.10$ & $<.005$ & $<.030$ & $<.040$ & $<.030$ & 0.29 \\
\hline MW226M & $06-06-96$ & $<.20$ & $<.20$ & $<.30$ & $<.10$ & $<.005$ & $<.030$ & $<.040$ & $<.030$ & 0.24 \\
\hline MW227D & $08-22-95$ & $<.20$ & $<.20$ & $<.30$ & $<.10$ & $<.005$ & $<.030$ & $<.040$ & $<.030$ & 0.00 \\
\hline MW227D & $05-02-96$ & $<.20$ & $<.20$ & $<.30$ & $<.10$ & $<.005$ & $<.030$ & $<.040$ & $<.030$ & 0.03 \\
\hline MW227S & $05-06-96$ & $<.20$ & $<.20$ & $<.30$ & $<10$ & $<.005$ & $<.030$ & $<.040$ & $<.030$ & 2.12 \\
\hline MW37D & $07.27-95$ & $<.20$ & $<.20$ & $<.30$ & $<.10$ & $<.005$ & $<.030$ & $<.040$ & $<.030$ & 0.00 \\
\hline MW37S & $08-07-95$ & $<.20$ & $<.20$ & $<.30$ & $<.10$ & $<.005$ & $\begin{array}{c}<.030 \\
\therefore\end{array}$ & $<.040$ & $<.030$ & 0.49 \\
\hline MW37S(d) & $08-0495$ & $<.20$ & $<.20$ & - & $<.10$ & $<.005$ & $<.030$ & $<.040$ & $<.030$ & -- \\
\hline MW37S & $05-28-96$ & $<.20$ & $<.20$ & $<.30$ & $<.10$ & $<.005$ & $<.030$ & $<.040$ & $<.030$ & 0.61 \\
\hline MW39D & $08-01-95$ & $<.20$ & $<.20$ & $<.30$ & $<.10$ & $<.005$ & $<.030$ & $<.040$ & $<.030$ & 0.01 \\
\hline
\end{tabular}




\begin{tabular}{|c|c|c|c|c|c|c|c|c|c|c|c|}
\hline \multicolumn{11}{|c|}{ METALS } & \multirow[b]{2}{*}{$\begin{array}{l}\text { Sample } \\
\text { ident- } \\
\text { ification } \\
\text { number }\end{array}$} \\
\hline $\begin{array}{c}\text { Iron, } \\
\text { field, } \\
(\mathrm{mg} / \mathrm{L} \\
\text { as } \\
\left.\mathrm{Fe}^{+2}\right)\end{array}$ & $\begin{array}{l}\text { Lead, } \\
(\mu \mathrm{g} / \mathrm{L} \\
\text { as } \mathrm{Pb})\end{array}$ & $\begin{array}{c}\text { Mang- } \\
\text { anese, } \\
(\mu \mathrm{g} / \mathrm{L} \\
\text { as } \mathrm{Mn})\end{array}$ & $\begin{array}{c}\text { Merc- } \\
\text { ury, } \\
(\mu \mathrm{g} / \mathrm{L} \\
\text { as } \mathrm{Hg})\end{array}$ & $\begin{array}{l}\text { Moly- } \\
\text { bden- } \\
\text { um( } \mu \mathrm{g} / \\
\mathrm{L} \text { as } \\
\mathrm{Mo})\end{array}$ & $\begin{array}{c}\text { Nickel, } \\
(\mu \mathrm{g} / \mathrm{L} \\
\text { as } \mathrm{Ni})\end{array}$ & $\begin{array}{l}\text { Selen- } \\
\text { ium, } \\
(\mu \mathrm{g} / \mathrm{L} \\
\text { as } \mathrm{Se})\end{array}$ & $\begin{array}{l}\text { Silver, } \\
(\mu \mathrm{g} / \mathrm{L} \\
\text { as } \mathrm{Ag})\end{array}$ & $\begin{array}{l}\text { Thal- } \\
\text { lium, } \\
\text { ( } \mu \mathrm{g} / \mathrm{L} \\
\text { as } \mathrm{Tl} \text { ) }\end{array}$ & $\begin{array}{l}\text { Vana- } \\
\text { dium, } \\
(\mu \mathrm{g} / \mathrm{L} \\
\text { as } \mathrm{V})\end{array}$ & $\begin{array}{c}\text { Zinc, } \\
(\mu \mathrm{g} / \mathrm{L} \\
\text { as } \mathrm{Z})\end{array}$ & \\
\hline \multicolumn{12}{|c|}{ GROUND-WATER SAMPLES--CONTINUED } \\
\hline 5.99 & $<.20$ & 0.056 & $<.002$ & $<.040$ & $<.040$ & $<.40$ & $<.040$ & $<5.0$ & $<.040$ & $<.010$ & GS4S \\
\hline 1.72 & $<.20$ & 0.057 & $<.002$ & $<.040$ & $<.040$ & $<.40$ & $<.040$ & $<5.0$ & $<.040$ & $<.010$ & GS4S \\
\hline 0.03 & $<.20$ & 0.028 & $<.002$ & $<.040$ & $<.040$ & $<.40$ & $<.040$ & $<5.0$ & $<.040$ & 0.020 & GSCP3D \\
\hline 9.72 & $<.20$ & 0.048 & $<.002$ & $<.040$ & $<.040$ & $<.40$ & $<.040$ & $<5.0$ & $<.040$ & $<.010$ & GSCP3M \\
\hline 4.30 & $<.20$ & 0.050 & $<.002$ & $<.040$ & $<.040$ & $<.40$ & $<.040$ & $<5.0$ & $<.040$ & $<.010$ & GSCP4M \\
\hline 5.07 & $<.20$ & 0.060 & $<.002$ & $<.040$ & $<.040$ & $<.40$ & $<.040$ & $<5.0$ & $<.040$ & 0.035 & GSCP5M \\
\hline-- & $<.20$ & 0.060 & $<.002$ & $<.040$ & $<.040$ & $<.40$ & $<.040$ & $<5.0$ & $<.040$ & 0.036 & $\operatorname{GSCPSM}(\mathrm{d})$ \\
\hline 6.51 & $<.20$ & 0.062 & $<.002$ & $<.040$ & 0.050 & $<.40$ & $<.040$ & $<5.0$ & $<.040$ & 0.032 & GSCP6D \\
\hline 2.00 & $<.20$ & 0.066 & $<.002$ & $<.040$ & $<.040$ & $<.40$ & $<.040$ & $<5.0$ & $<.040$ & 0.029 & GSCP8 \\
\hline 0.00 & $<.20$ & 0.053 & $<.002$ & $<.040$ & $<.040$ & $<.40$ & $<.040$ & $<5.0$ & $<.040$ & 0.011 & GSCP9S \\
\hline 1.17 & $<.20$ & 0.076 & $<.002$ & $<.040$ & $<.040$ & $<.40$ & $<.040$ & $<5.0$ & $<.040$ & $<.010$ & MW11 \\
\hline 0.01 & $<.20$ & $<.010$ & $<.002$ & $<.040$ & $<.040$ & $<.40$ & $<.040$ & $<5.0$ & $<.040$ & $<.010$ & MW18 \\
\hline 1.85 & $<.20$ & 0.032 & $<.002$ & $<.040$ & $<.040$ & $<.40$ & $<.040$ & $<5.0$ & $<.040$ & $<.010$ & MW19 \\
\hline 0.27 & $<.20$ & $<.010$ & $<.002$ & $<.040$ & $<.040$ & $<.40$ & $<.040$ & $<5.0$ & $<.040$ & $<.010$ & MW19 \\
\hline 1.23 & $<.20$ & 0.025 & $<.002$ & $<.040$ & $<.040$ & $<.40$ & $<.040$ & $<5.0$ & $<.040$ & $<.010$ & MWI9 \\
\hline 0.12 & $<.20$ & 0.046 & $<.002$ & $<.040$ & $<.040$ & $<.40$ & $<.040$ & $<5.0$ & $<.040$ & 0.017 & MW20 \\
\hline 0.00 & $<.20$ & $<.010$ & $<.002$ & $<.040$ & $<.040$ & $<.40$ & $<.040$ & $<5.0$ & $<.040$ & 0.012 & MW206D \\
\hline 0.01 & $<.20$ & $<.010$ & $<.002$ & $<.040$ & $<.040$ & $<.40$ & $<.040$ & $<5.0$ & $<.040$ & 0.016 & MW206D \\
\hline -. & $<.20$ & $<.010$ & $<.002$ & $<.040$ & $<.040$ & $<.40$ & $<.040$ & $<5.0$ & $<.040$ & 0.013 & $M W 206 D(d)$ \\
\hline 0.29 & $<.20$ & 0.036 & $<.002$ & $<.040$ & $<.040$ & $<.40$ & $<.040$ & $<5.0$ & $<.040$ & 0.017 & MW206M \\
\hline 0.76 & $<.20$ & 0.034 & $<.002$ & $<.040$ & $<.040$ & $<.40$ & $<.040$ & $<5.0$ & $<.040$ & $<.010$ & MW206M \\
\hline 1.16 & $<.20$ & $<.010$ & $<.002$ & $<.040$ & $<.040$ & $<.40$ & $<.040$ & $<5.0$ & $<.040$ & $<.010$ & MW2I \\
\hline 0.00 & $<.20$ & $<.010$ & $<.002$ & $<.040$ & $<.040$ & $<.40$ & $<.040$ & $<5.0$ & $<.040$ & $<.010$ & MW226D \\
\hline 0.23 & $<.20$ & 0.019 & $<.002$ & $<.040$ & $<.040$ & $<.40$ & $<.040$ & $<5.0$ & $<.040$ & $<.010$ & MW226M \\
\hline 0.23 & $<.20$ & 0.017 & $<.002$ & $<.040$ & $<.040$ & $<.40$ & $<.040$ & $<5.0$ & $<.040$ & 0.013 & MW226M \\
\hline 0.00 & $<.20$ & $<.010$ & $<.002$ & $<.040$ & $<.040$ & $<.40$ & $<.040$ & $<5.0$ & $<.040$ & 0.024 & MW227D \\
\hline 0.00 & $<.20$ & $<.010$ & $<.002$ & $<.040$ & $<.040$ & $<.40$ & $<.040$ & $<5.0$ & $<.040$ & 0.017 & MW227D \\
\hline 2.05 & $<.20$ & 0.099 & $<.002$ & $<.040$ & $<.040$ & $<.40$ & $<.040$ & $<5.0$ & $<.040$ & $<.010$ & MW227S \\
\hline 0.00 & $<.20$ & $<.010$ & $<.002$ & $<.040$ & $<.040$ & $<.40$ & $<.040$ & $<5.0$ & $<.040$ & 0.057 & MW37D \\
\hline 0.41 & $<.20$ & 0.17 & $<.002$ & $<.040$ & $<.040$ & $<.40$ & $<.040$ & $<5.0$ & $<.040$ & 0.011 & MW37S \\
\hline .. & $<.20$ & 0.19 & $<.002$ & $<.040$ & $<.040$ & $<.40$ & $<.040$ & $<5.0$ & $<.040$ & 0.013 & MW37S(d) \\
\hline 0.06 & $<.20$ & 0.16 & $<.002$ & $<.(140$ & $<.040$ & $<.40$ & $<.040$ & $<5.0$ & $<.040$ & $<.010$ & MW37S \\
\hline-- & $<.20$ & $<.010$ & $<.002$ & $<.040$ & $<.040$ & $<.40$ & $<.040$ & $<5.0$ & $<.040$ & 0.024 & MW39D \\
\hline
\end{tabular}


Table 5. Ground-and surface-water quality data at the natural-attenuation study area, Dover Air Force Base, Kent County, Delaware, July - August 1995, May-July 1996, and August 1996, for inorganic constituents-Continued

\begin{tabular}{|c|c|c|c|c|c|c|c|c|c|c|}
\hline \multirow[b]{2}{*}{$\begin{array}{c}\text { Sample } \\
\text { ident- } \\
\text { ification } \\
\text { number }\end{array}$} & \multicolumn{9}{|c|}{ METALS } & \multirow[b]{2}{*}{$\begin{array}{c}\begin{array}{c}\text { Iron, } \\
\text { field, } \\
(\mathrm{mg} / \mathrm{L} \text { as }\end{array} \\
\mathrm{Fe}^{+2}+ \\
\left.\mathrm{Fe}^{+3}\right)\end{array}$} \\
\hline & $\begin{array}{l}\text { Sample } \\
\text { date }\end{array}$ & $\begin{array}{c}\text { Alum- } \\
\text { inum, } \\
(\mu \mathrm{g} / \mathrm{L} \text { as } \\
\mathrm{Al})\end{array}$ & $\begin{array}{l}\text { Anti- } \\
\text { mony, } \\
(\mu g / L \text { as } \\
\text { Sb) }\end{array}$ & $\begin{array}{c}\text { Arsenic, } \\
\text { ( } \mu \mathrm{g} / \mathrm{Las} \\
\text { As) }\end{array}$ & $\begin{array}{c}\text { Barium. } \\
(\mu \mathrm{g} / \mathrm{L} \text { as } \\
\mathrm{Ba})\end{array}$ & $\begin{array}{l}\text { Cad- } \\
\text { mium, } \\
(\mu \mathrm{g} / \mathrm{L} \text { as } \\
\text { Cd) }\end{array}$ & $\begin{array}{c}\text { Chro- } \\
\text { mium, } \\
(\mu \mathrm{g} / \mathrm{L} \text { as } \\
\mathrm{Cr})\end{array}$ & $\begin{array}{c}\text { Cobalt, } \\
(\mu \mathrm{g} / \mathrm{Las} \\
\mathrm{Co})\end{array}$ & $\begin{array}{c}\text { Copper, } \\
(\mu \mathrm{g} / \mathrm{L} \text { as } \\
\mathrm{Cu})\end{array}$ & \\
\hline \multicolumn{11}{|c|}{ GROUND-WATER SAMPLES--CONTINUED } \\
\hline MW39D(d) & $08-01-95$ & $<.20$ & $<.20$ & $<.30$ & $<.10$ & $<.005$ & $<.030$ & $<.040$ & $<.030$ & -- \\
\hline MW39S & $07-26-95$ & $<.20$ & $<.20$ & $<.30$ & $<.10$ & $<.005$ & $<.030$ & $<.040$ & $<.030$ & 0.07 \\
\hline MW39S & $06-12-96$ & $<.20$ & $<.20$ & $<.30$ & $<.10$ & $<.005$ & $<.030$ & $<.040$ & $<.030$ & 0.00 \\
\hline MW40D & $08-03-95$ & $<.20$ & $<.20$ & $<.30$ & $<.10$ & $<.005$ & $<.030$ & $<.040$ & $<.030$ & 0.00 \\
\hline MW40S & $08-03-95$ & $<.20$ & $<.20$ & $<.30$ & $<.10$ & $<.005$ & $<.030$ & $<.040$ & $<.030$ & 0.00 \\
\hline MW4ID & $07-31-95$ & $<.20$ & $<.20$ & $<.30$ & $<.10$ & $<.005$ & $<.030$ & $<.040$ & $<.030$ & 0.01 \\
\hline MW41S & $08-01-95$ & $<.20$ & $<.20$ & $<.30$ & $<.10$ & $<.005$ & $<.030$ & $<.040$ & $<.030$ & 1.73 \\
\hline MW43S & $07-26-95$ & $<.20$ & $<.20$ & $<.30$ & $<.10$ & $<.005$ & $<.030$ & $<.040$ & $<.030$ & 3.62 \\
\hline MW43S(d) & $07-26-95$ & $<.20$ & $<.20$ & -- & $<.10$ & $<.005$ & $<.030$ & $<.040$ & $<.030$ & -- \\
\hline MW61S & $08-04-95$ & $<.20$ & $<.20$ & $<.30$ & 0.32 & $<.005$ & $<.030$ & $<.040$ & $<.030$ & 17.52 \\
\hline MW61S & $06-21-96$ & $<.20$ & $<.20$ & $<.30$ & 0.36 & $<.005$ & $<.030$ & $<.040$ & $<.030$ & 18.2 \\
\hline MW62D & $06-21-96$ & $<.20$ & $<.20$ & $<.30$ & $<.10$ & $<.005$ & $<.030$ & $<.040$ & $<.030$ & 0.00 \\
\hline MW62S & $06-18-96$ & $<.20$ & $<.20$ & $<.30$ & $<.10$ & $<.005$ & $<.030$ & $<.040$ & $<.030$ & 5.96 \\
\hline MW64D & $07-11-96$ & $<.20$ & $<.20$ & $<.30$ & $<.10$ & $<.005$ & $<.030$ & $<.040$ & $<.030$ & -- \\
\hline MW64S & $06-14-96$ & $<.20$ & $<.20$ & $<.30$ & $<.10$ & $<.005$ & $<.030$ & $<.040$ & $<.030$ & 9.24 \\
\hline MW64S(d) & $06-14-96$ & $<.20$ & $<.20$ & $<.30$ & $<.10$ & $<.005$ & $<.030$ & $<.040$ & $<.030$ & $-\cdot$ \\
\hline MWD4B & $05-31-96$ & $<.20$ & $<.20$ & $<.30$ & $<.10$ & $<.005$ & $<.030$ & $<.040$ & $<.030$ & 0.00 \\
\hline \multicolumn{11}{|c|}{ SURFACE-WATER SAMPLES } \\
\hline GSisW & $08-10-95$ & $<.20$ & $<.20$ & $<.30$ & $<.10$ & $<.005$ & $<.030$ & $<.040$ & $<.030$ & 2.64 \\
\hline GSISW & $05-23-96$ & $<.20$ & $<.20$ & $<.30$ & $<.10$ & $<.005$ & $<.030$ & $<.040$ & $<.030$ & 0.18 \\
\hline GS2SW & $08-10-95$ & $<.20$ & $<.20$ & $<.30$ & 0.15 & $<.005$ & $<.030$ & 0.069 & $<.030$ & 6.23 \\
\hline GS2SW & $06-05-96$ & $<.20$ & $<.20$ & $<.30$ & $<.10$ & $<.005$ & $<.030$ & $<.040$ & $<.030$ & 0.18 \\
\hline GS3SW & $08-17-95$ & $<.20$ & $<.20$ & $<.30$ & $<.10$ & $<.005$ & $<.030$ & $<.040$ & $<.030$ & 0.56 \\
\hline GS3SW & $05-22-96$ & $<.20$ & $<.20$ & $<.30$ & $<.10$ & $<.005$ & $<.030$ & $<.040$ & $<.030$ & 0.39 \\
\hline GS4SW & $08-16-95$ & $<.20$ & $<.20$ & $<.30$ & $<.10$ & $<.005$ & $<.030$ & $<.040$ & $<.030$ & 0.32 \\
\hline GS4SW(d) & $06-14-96$ & $<.20$ & $<.20$ & $<.30$ & $<.10$ & $<.005$ & $<.030$ & $<.040$ & $<.030$ & 0.32 \\
\hline GS4SW & $05-20-96$ & $<.20$ & $<.20$ & $<.30$ & $<.10$ & $<.005$ & $<.030$ & $<.040$ & $<.030$ & 0.32 \\
\hline \multicolumn{11}{|c|}{ QUALITY-ASSURANCE SAMPLES } \\
\hline Eq. Blank (1) & $07-27-95$ & $<.20$ & $<.20$ & $<.30$ & $<.10$ & $<.005$ & $<.030$ & $<.040$ & $<.030$ & $\cdots$ \\
\hline Eq. Blank (2) & $08-02-95$ & $<.20$ & $<.20$ & $<.30$ & $<.10$ & $<.005$ & $<.030$ & $<.040$ & $<.030$ & -- \\
\hline Eq. Blank (3) & $08-03-95$ & $<.20$ & $<.20$ & $<.30$ & $<.10$ & $<.005$ & $<.030$ & $<.040$ & $<.030$ & -- \\
\hline Eq. Blank (4) & $08-09-95$ & $<.20$ & $<20$ & $<.30$ & $<.10$ & $<.005$ & $<.030$ & $<.040$ & $<.030$ & -- \\
\hline Eq. Blank (5) & $08-11-95$ & $<.20$ & $<.20$ & $<.30$ & $<.10$ & $<.005$ & $<.030$ & $<.040$ & $<.030$ & -- \\
\hline Eq. Blank (G) & $08-16-95$ & $<.20$ & $<.20$ & $<.30$ & $<.10$ & $<.005$ & $<.030$ & $<.040$ & $<.030$ & -- \\
\hline
\end{tabular}




\begin{tabular}{|c|c|c|c|c|c|c|c|c|c|c|c|}
\hline \multicolumn{11}{|c|}{ METALS } & \multirow[b]{2}{*}{$\begin{array}{l}\text { Sample } \\
\text { ident- } \\
\text { ification } \\
\text { number }\end{array}$} \\
\hline $\begin{array}{l}\text { Iron, } \\
\text { field, } \\
(\mathrm{mg} / \mathrm{L} \\
\text { as } \\
\left.\mathrm{Fe}^{+2}\right)\end{array}$ & $\begin{array}{l}\text { Lead, } \\
(\mu \mathrm{g} / \mathrm{L} \\
\text { as } \mathrm{Pb})\end{array}$ & $\begin{array}{c}\text { Mang- } \\
\text { anese, } \\
(\mu \mathrm{g} / \mathrm{L} \\
\text { as } \mathrm{Mn})\end{array}$ & $\begin{array}{c}\text { Merc- } \\
\text { ury, } \\
(\mu \mathrm{g} / \mathrm{L} \\
\text { as } \mathrm{Hg})\end{array}$ & $\begin{array}{l}\text { Moly- } \\
\text { bden- } \\
\text { um( } \mu \mathrm{g} / \\
\mathrm{L} \text { as } \\
\text { Mo) }\end{array}$ & $\begin{array}{c}\text { Nickel, } \\
(\mu \mathrm{g} / \mathrm{L} \\
\text { as } \mathrm{Ni})\end{array}$ & $\begin{array}{l}\text { Selen- } \\
\text { ium, } \\
(\mu \mathrm{g} / \mathrm{L} \\
\text { as } \mathrm{Se})\end{array}$ & $\begin{array}{c}\text { Silver, } \\
(\mu \mathrm{g} / \mathrm{L} \\
\text { as } \mathrm{Ag})\end{array}$ & $\begin{array}{l}\text { Thal- } \\
\text { lium, } \\
\text { ( } \mu \mathrm{g} / \mathrm{L} \\
\text { as } \mathrm{Tl})\end{array}$ & $\begin{array}{l}\text { Vana- } \\
\text { dium, } \\
(\mu \mathrm{g} / \mathrm{L} \\
\text { as } \mathrm{V})\end{array}$ & $\begin{array}{l}\text { Zinc, } \\
(\mu \mathrm{g} / \mathrm{L} \\
\text { as } \mathrm{Z})\end{array}$ & \\
\hline \multicolumn{12}{|c|}{ GROUND-WATER SAMPLES--CONTINUED } \\
\hline -. & $<.20$ & $<.010$ & $<.002$ & $<.040$ & $<.040$ & $<.40$ & $<.040$ & $<5.0$ & $<.040$ & 0.025 & MW39D(d) \\
\hline 0.08 & $<.20$ & 0.016 & $<.002$ & $<.040$ & $<.040$ & $<.40$ & $<.040$ & $<5.0$ & $<.040$ & 0.018 & MW39S \\
\hline 0.00 & $<.20$ & $<.010$ & $<.002$ & $<.040$ & $<.040$ & $<.40$ & $<.040$ & $<5.0$ & $<.040$ & $<.010$ & MW39S \\
\hline-- & $<.20$ & $<.010$ & $<.002$ & $<.040$ & $<.040$ & $<.40$ & $<.040$ & $<5.0$ & $<.040$ & 0.012 & MW40D \\
\hline 0.00 & $<.20$ & $<.010$ & $<.002$ & $<.040$ & $<.040$ & $<.40$ & $<.040$ & $<5.0$ & $<.040$ & $<.010$ & MW40S \\
\hline 0.01 & $<.20$ & $<.010$ & $<.002$ & $<.040$ & $<.040$ & $<.40$ & $<.040$ & $<5.0$ & $<.040$ & $<.010$ & MW4ID \\
\hline 1.61 & $<.20$ & 0.029 & $<.002$ & $<.040$ & $<.040$ & $<.40$ & $<.040$ & $<5.0$ & $<.040$ & $<.010$ & MW4IS \\
\hline 2.80 & $<.20$ & 0.052 & $<.002$ & $<.040$ & $<.040$ & $<.40$ & $<.040$ & $<5.0$ & $<.040$ & 0.034 & MW43S \\
\hline -- & $<.20$ & 0.053 & $<.002$ & $<.040$ & $<.040$ & $<.40$ & $<.040$ & $<5.0$ & $<.040$ & 0.035 & MW43S(d) \\
\hline 10.85 & $<.20$ & 0.37 & $<.002$ & $<.040$ & $<.040$ & $<.40$ & $<.040$ & $<5.0$ & $<.040$ & $<.010$ & MW61S \\
\hline 16.84 & $<.20$ & 0.40 & $<.002$ & $<.040$ & $<.040$ & $<.40$ & $<.040$ & $<5.0$ & $<.040$ & $<.010$ & MW61S \\
\hline 0.00 & $<.20$ & $<.010$ & $<.002$ & $<.040$ & $<.040$ & $<.40$ & $<.040$ & $<5.0$ & $<.040$ & 0.016 & MW62D \\
\hline 5.68 & $<.20$ & 0.055 & $<.002$ & $<.040$ & $<.040$ & $<.40$ & $<.040$ & $<5.0$ & $<.040$ & 0.016 & MW62S \\
\hline -- & $<.20$ & 0.057 & $<.002$ & $<.040$ & $<.040$ & $<.40$ & $<.040$ & $<5.0$ & $<.040$ & 0.018 & MW64D \\
\hline 8.84 & $<.20$ & 0.44 & $<.002$ & $<.040$ & $<.040$ & $<.40$ & $<.040$ & $<5.0$ & $<.040$ & 0.020 & MW64S \\
\hline -- & $<.20$ & 0.44 & $<.002$ & $<.040$ & $<.040$ & $<.40$ & $<.040$ & $<5.0$ & $<.040$ & 0.014 & MW64S(d) \\
\hline 0.00 & $<.20$ & 0.015 & $<.002$ & $<.040$ & $<.040$ & $<.40$ & $<.040$ & $<5.0$ & $<.040$ & $<.010$ & MWD4B \\
\hline \multicolumn{12}{|c|}{ SURFACE-WATER SAMPLES } \\
\hline 0.13 & $<.20$ & 0.16 & $<.002$ & $<.040$ & $<.040$ & $<.40$ & $<.040$ & $<5.0$ & $<.040$ & $<.010$ & GSISW \\
\hline 0.11 & $<.20$ & 0.078 & $<.002$ & $<.040$ & $<.040$ & $<.40$ & $<.040$ & $<5.0$ & $<.040$ & $<.010$ & GSISW \\
\hline 3.25 & $<.20$ & 1.2 & $<.002$ & $<.040$ & $<.040$ & $<.40$ & $<.040$ & $<5.0$ & $<.040$ & 0.18 & GS2SW \\
\hline 0.12 & $<.20$ & 0.035 & $<.002$ & $<.040$ & $<.040$ & $<.40$ & $<.040$ & $<5.0$ & $<.040$ & $<.010$ & GS2SW \\
\hline 0.03 & $<.20$ & 0.078 & $<.002$ & $<.040$ & $<.040$ & $<.40$ & $<.040$ & $<5.0$ & $<.040$ & 0.013 & GS3SW \\
\hline 0.04 & $<.20$ & 0.14 & $<.002$ & $<.040$ & $<.040$ & $<.40$ & $<.040$ & $<5.0$ & $<.040$ & 0.029 & GS3SW \\
\hline 0.02 & $<.20$ & 0.23 & $<.002$ & $<.040$ & $<.040$ & $<.40$ & $<.040$ & $<5.0$ & $<.040$ & $<.010$ & GS4SW \\
\hline-- & $<.20$ & 0.23 & $<.002$ & $<.040$ & $<.040$ & $<.40$ & $<.040$ & $<5.0$ & $<.040$ & $<.010$ & GS4SW(d) \\
\hline 0.13 & $<.20$ & 0.097 & $<.002$ & $<.040$ & $<.040$ & $<.40$ & $<.040$ & $<5.0$ & $<.040$ & $<.010$ & GS4SW \\
\hline \multicolumn{12}{|c|}{ QUALITY-ASSURANCE SAMPLES } \\
\hline-- & $<.20$ & $<.010$ & $<.002$ & $<.040$ & $<.040$ & $<.40$ & $<.040$ & $<5.0$ & $<.040$ & $<.010$ & Eq. Blank (1) \\
\hline-- & $<.20$ & $<.010$ & $<.002$ & $<.040$ & $<.040$ & $<.40$ & $<.040$ & $<5.0$ & $<.040$ & $<.010$ & Eq. Blank (2) \\
\hline- & $<.20$ & $<.010$ & $<.002$ & $<.040$ & $<.040$ & $<.40$ & $<.040$ & $<5.0$ & $<.040$ & $<.010$ & Eq. Blank (3) \\
\hline-- & $<.20$ & $<.010$ & $<.002$ & $<.040$ & $<.040$ & $<.40$ & $<.040$ & $<5.0$ & $<.040$ & $<.010$ & Eq. Blank (4) \\
\hline -- & $<.20$ & $<.010$ & $<.002$ & $<.040$ & $<.040$ & $<.40$ & $<.040$ & $<5.0$ & $<.040$ & $<.010$ & Eq. Blank (5) \\
\hline -. & $<.20$ & $<.010$ & $<.002$ & $<.040$ & $<.040$ & $<.40$ & $<.040$ & $<5.0$ & $<.040$ & $<.010$ & Eq. Blank (6) \\
\hline
\end{tabular}


Table 5. Ground-and surface-water quality data at the natural-attenuation study area, Dover Air Force Base, Kent County, Delaware, July - August 1995, May - July 1996, and August 1996, for inorganic constituents-Continued

\begin{tabular}{|c|c|c|c|c|c|c|c|c|c|c|}
\hline \multirow[b]{2}{*}{$\begin{array}{l}\text { Sample } \\
\text { ident- } \\
\text { ification } \\
\text { number }\end{array}$} & \multicolumn{9}{|c|}{ METALS } & \multirow[b]{2}{*}{$\begin{array}{c}\text { Iron, } \\
\text { field, } \\
(\mathrm{mg} / \mathrm{Las} \\
\mathrm{Fe}^{+2}+ \\
\mathrm{Fe}^{+3} \text { ) }\end{array}$} \\
\hline & $\begin{array}{c}\text { Sample } \\
\text { date }\end{array}$ & $\begin{array}{l}\text { Alum- } \\
\text { inum, } \\
(\mu \mathrm{g} / \mathrm{L} \text { as } \\
\mathrm{Al})\end{array}$ & $\begin{array}{c}\text { Anti- } \\
\text { mony, } \\
(\mu \mathrm{g} / \mathrm{L} \text { as } \\
\mathrm{Sb})\end{array}$ & $\begin{array}{c}\text { Arsenic, } \\
(\mu \mathrm{g} / \mathrm{L} \text { as } \\
\text { As) }\end{array}$ & $\begin{array}{c}\text { Barium, } \\
(\mu \mathrm{g} / \mathrm{L} \text { as } \\
\text { Ba) }\end{array}$ & $\begin{array}{l}\text { Cad- } \\
\text { mium, } \\
(\mu \mathrm{g} / \mathrm{L} \text { as } \\
\text { Cd) }\end{array}$ & $\begin{array}{c}\text { Chro- } \\
\text { mium, } \\
(\mu \mathrm{g} / \mathrm{L} \text { as } \\
\mathrm{Cr})\end{array}$ & $\begin{array}{c}\text { Cobalt, } \\
(\mu \mathrm{g} / \mathrm{L} \text { as } \\
\text { Co })\end{array}$ & $\begin{array}{l}\text { Copper, } \\
(\mu \mathrm{g} / \mathrm{L} \text { as } \\
\mathrm{Cu})\end{array}$ & \\
\hline \multicolumn{11}{|c|}{ QUALITY-ASSURANCE SAMPLES--CONTINUED } \\
\hline Eq. Blank (7) & $08-16-95$ & $<.20$ & $<.20$ & $<.30$ & $<.10$ & $<.005$ & $<.030$ & $<.040$ & $<.030$ & -- \\
\hline Eq. Blank (8) & $08-18-95$ & $<.20$ & $<.20$ & $<.30$ & $<.10$ & $<.005$ & $<.030$ & $<.040$ & $<.030$ & -- \\
\hline Eq. Blank (9) & $08-22-95$ & $<.20$ & $<.20$ & $<.30$ & $<.10$ & $<.005$ & $<.030$ & $<.040$ & $<.030$ & -- \\
\hline Eq. Blank (10) & $05-01-96$ & $<.20$ & $<.20$ & $<.30$ & $<.10$ & $<.005$ & $<.030$ & $<.040$ & $<.030$ & -- \\
\hline Eq. Blank (11) & $05-21-96$ & $<.20$ & $<.20$ & $<.30$ & $<.10$ & $<.005$ & $<.030$ & $<.040$ & $<.030$ & -. \\
\hline Eq. Blank (12) & $05-22-96$ & $<.20$ & $<.20$ & $<.30$ & $<.10$ & $<.005$ & $<.030$ & $<.040$ & $<.030$ & -- \\
\hline Eq. Blank (13) & $05-30-96$ & $<.20$ & $<.20$ & $<.30$ & $<.10$ & $<.005$ & $<.030$ & $<.040$ & $<.030$ & -- \\
\hline Eq. Blank (14) & $06-05-96$ & $<.20$ & $<.20$ & $<.30$ & $<.10$ & $<.005$ & $<.030$ & $<.040$ & $<.030$ & -. \\
\hline Eq. Blank (15) & $06-12-96$ & $<.20$ & $<.20$ & $<.30$ & $<.10$ & $<.005$ & $<.030$ & $<.040$ & $<.030$ & -- \\
\hline Eq. Blank (16) & $06-13-96$ & $<.20$ & $<.20$ & $<.30$ & $<.10$ & $<.005$ & $<.030$ & $<.040$ & $<.030$ & -- \\
\hline Eq. Blank (17) & $06-14-96$ & $<.20$ & $<.20$ & $<.30$ & $<.10$ & $<.005$ & $<.030$ & $<.040$ & $<.030$ & -. \\
\hline
\end{tabular}




\begin{tabular}{|c|c|c|c|c|c|c|c|c|c|c|c|}
\hline \multicolumn{11}{|c|}{ METALS } & \multirow[b]{2}{*}{$\begin{array}{l}\text { Sample } \\
\text { ident- } \\
\text { ification } \\
\text { number }\end{array}$} \\
\hline $\begin{array}{l}\text { Iron, } \\
\text { field, } \\
(\mathrm{mg} / \mathrm{L} \\
\text { as } \\
\left.\mathrm{Fe}^{+2}\right)\end{array}$ & $\begin{array}{l}\text { Lead, } \\
(\mu \mathrm{g} / \mathrm{L} \\
\text { as } \mathrm{Pb})\end{array}$ & $\begin{array}{l}\text { Mang- } \\
\text { anese, } \\
(\mu \mathrm{g} / \mathrm{L} \\
\text { as } \mathrm{Mn})\end{array}$ & $\begin{array}{c}\text { Merc- } \\
\text { ury, } \\
(\mu \mathrm{g} / \mathrm{L} \\
\text { as } \mathrm{Hg})\end{array}$ & $\begin{array}{l}\text { Moly- } \\
\text { bden- } \\
\text { um( } \mu \mathrm{g} / \\
\mathrm{L} \text { as } \\
\mathrm{Mo})\end{array}$ & $\begin{array}{c}\text { Nickel, } \\
(\mu \mathrm{g} / \mathrm{L} \\
\text { as } \mathrm{Ni})\end{array}$ & $\begin{array}{c}\text { Selen- } \\
\text { ium, } \\
(\mu \mathrm{g} / \mathrm{L} \\
\text { as } \mathrm{Se})\end{array}$ & $\begin{array}{l}\text { Silver, } \\
(\mu \mathrm{g} / \mathrm{L} \\
\text { as } \mathrm{Ag})\end{array}$ & $\begin{array}{l}\text { Thal- } \\
\operatorname{lium}, \\
(\mu \mathrm{g} / \mathrm{L} \\
\text { as } \mathrm{Tl})\end{array}$ & $\begin{array}{l}\text { Vana- } \\
\text { dium, } \\
(\mu g / L \\
\text { as V) }\end{array}$ & $\begin{array}{l}\text { Zinc, } \\
(\mu g / L \\
\text { as Z) }\end{array}$ & \\
\hline \multicolumn{12}{|c|}{ QUALITY-ASSURANCE SAMPLES--CONTINUED } \\
\hline- & $<.20$ & $<.010$ & $<.002$ & $<.040$ & $<.040$ & $<.40$ & $<.040$ & $<5.0$ & $<.040$ & 0.016 & Eq. Blank (7) \\
\hline-- & $<.20$ & $<.010$ & $<.002$ & $<.040$ & $<.040$ & $<.40$ & $<.040$ & $<5.0$ & $<.040$ & $<.010$ & Eq. Blank (8) \\
\hline -. & $<.20$ & $<.010$ & $<.002$ & $<.040$ & $<.040$ & $<.40$ & $<.040$ & $<5.0$ & $<.040$ & $<.010$ & Eq. Blank (9) \\
\hline- & $<.20$ & $<.010$ & $<.002$ & $<.040$ & $<.040$ & $<.40$ & $<.040$ & $<5.0$ & $<.040$ & $<.010$ & Eq. Blank (10) \\
\hline .- & $<.20$ & $<.010$ & $<.002$ & $<.040$ & $<.040$ & $<.40$ & $<.040$ & $<5.0$ & $<.040$ & $<.010$ & Eq. Blank (11) \\
\hline-- & $<.20$ & $<.010$ & $<.002$ & $<.040$ & $<.040$ & $<.40$ & $<.040$ & $<5.0$ & $<.040$ & $<.010$ & Eq. Blank (12) \\
\hline -- & $<.20$ & $<.010$ & $<.002$ & $<.040$ & $<.040$ & $<.40$ & $<.040$ & $<5.0$ & $<.040$ & $<.010$ & Eq. Blank (13) \\
\hline-- & $<.20$ & $<.010$ & $<.002$ & $<.040$ & $<.040$ & $<.40$ & $<.040$ & $<5.0$ & $<.040$ & $<.010$ & Eq. Blank (14) \\
\hline-- & $<.20$ & $<.010$ & $<.002$ & $<.040$ & $<.040$ & $<.40$ & $<.040$ & $<5.0$ & $<.040$ & $<.010$ & Eq. Blank (15) \\
\hline-- & $<.20$ & $<.010$ & $<.002$ & $<.040$ & $<.040$ & $<.40$ & $<.040$ & $<5.0$ & $<.040$ & $<.010$ & Eq. Blank (16) \\
\hline -. & $<.20$ & $<.010$ & $<.002$ & $<.040$ & $<.040$ & $<.40$ & $<.040$ & $<5.0$ & $<.040$ & $<.010$ & Eq. Blank (17) \\
\hline
\end{tabular}




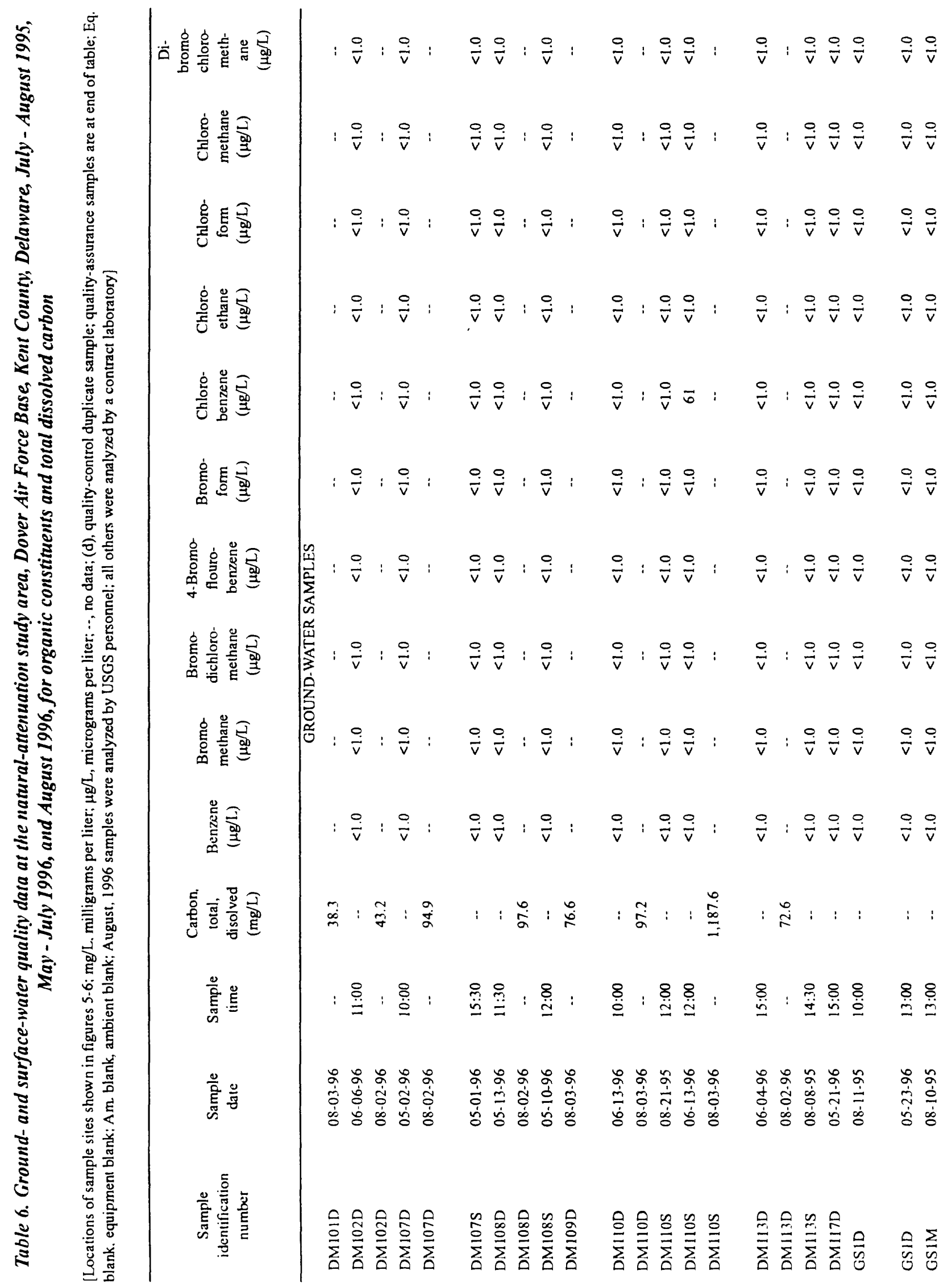




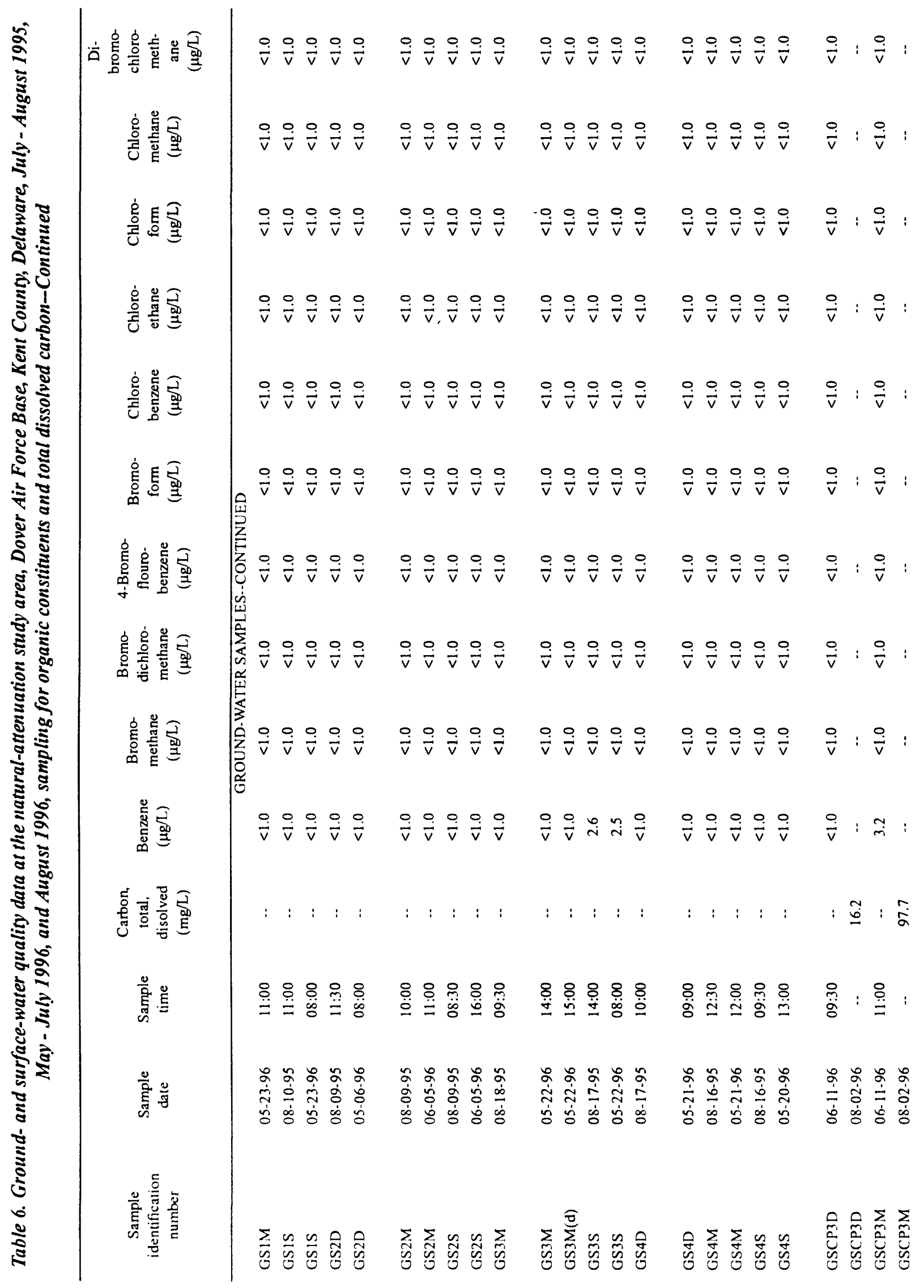




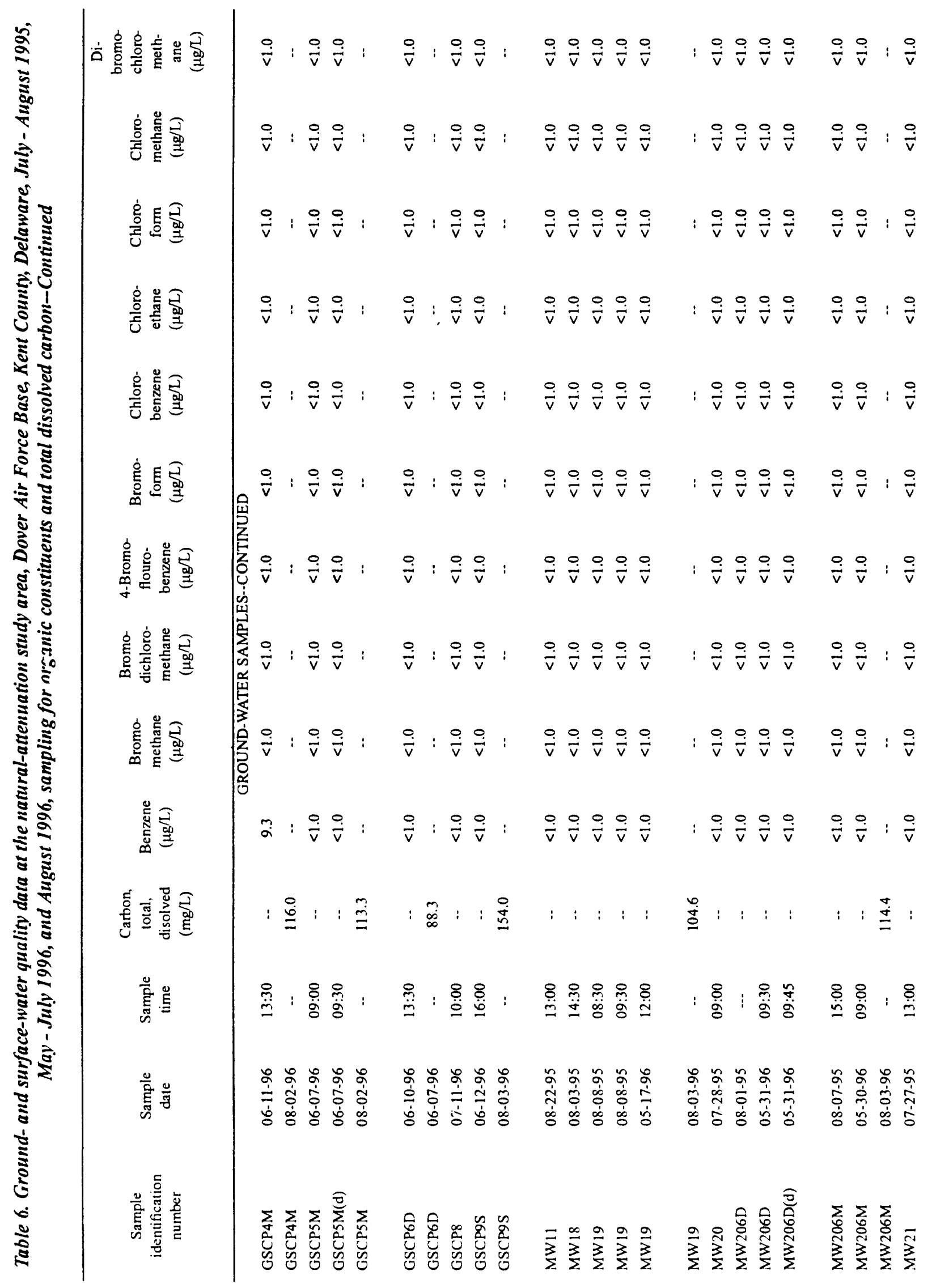




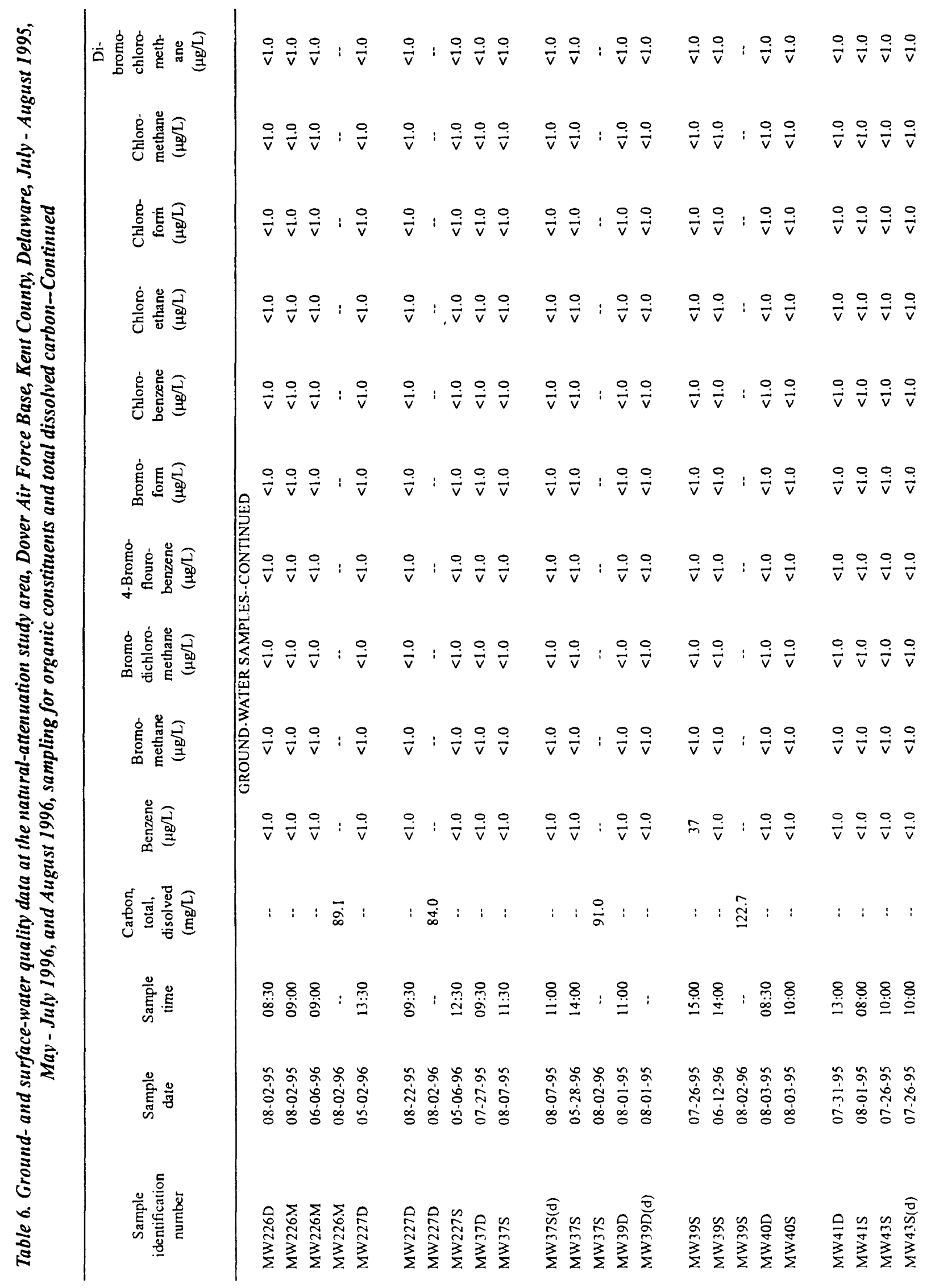




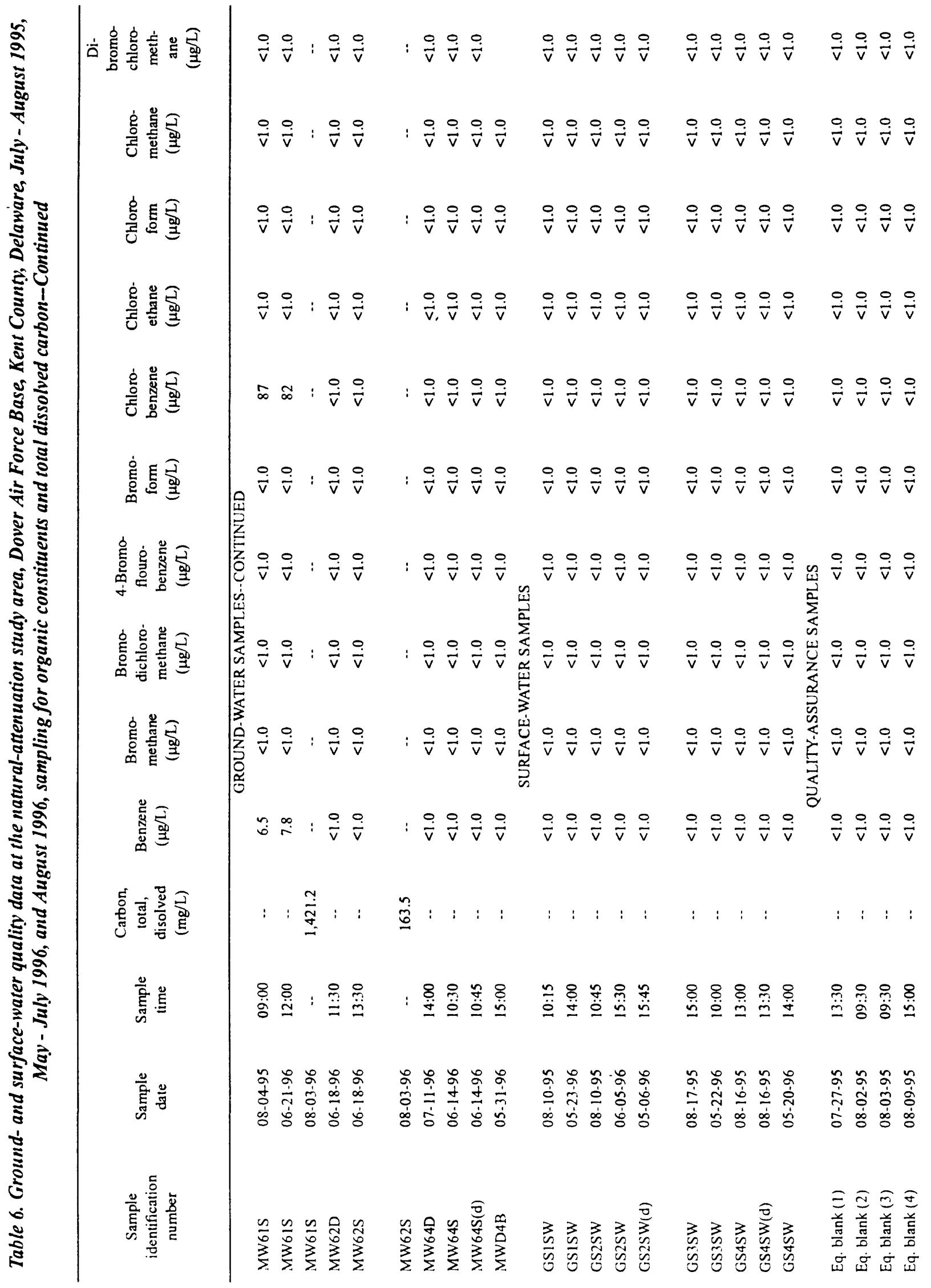




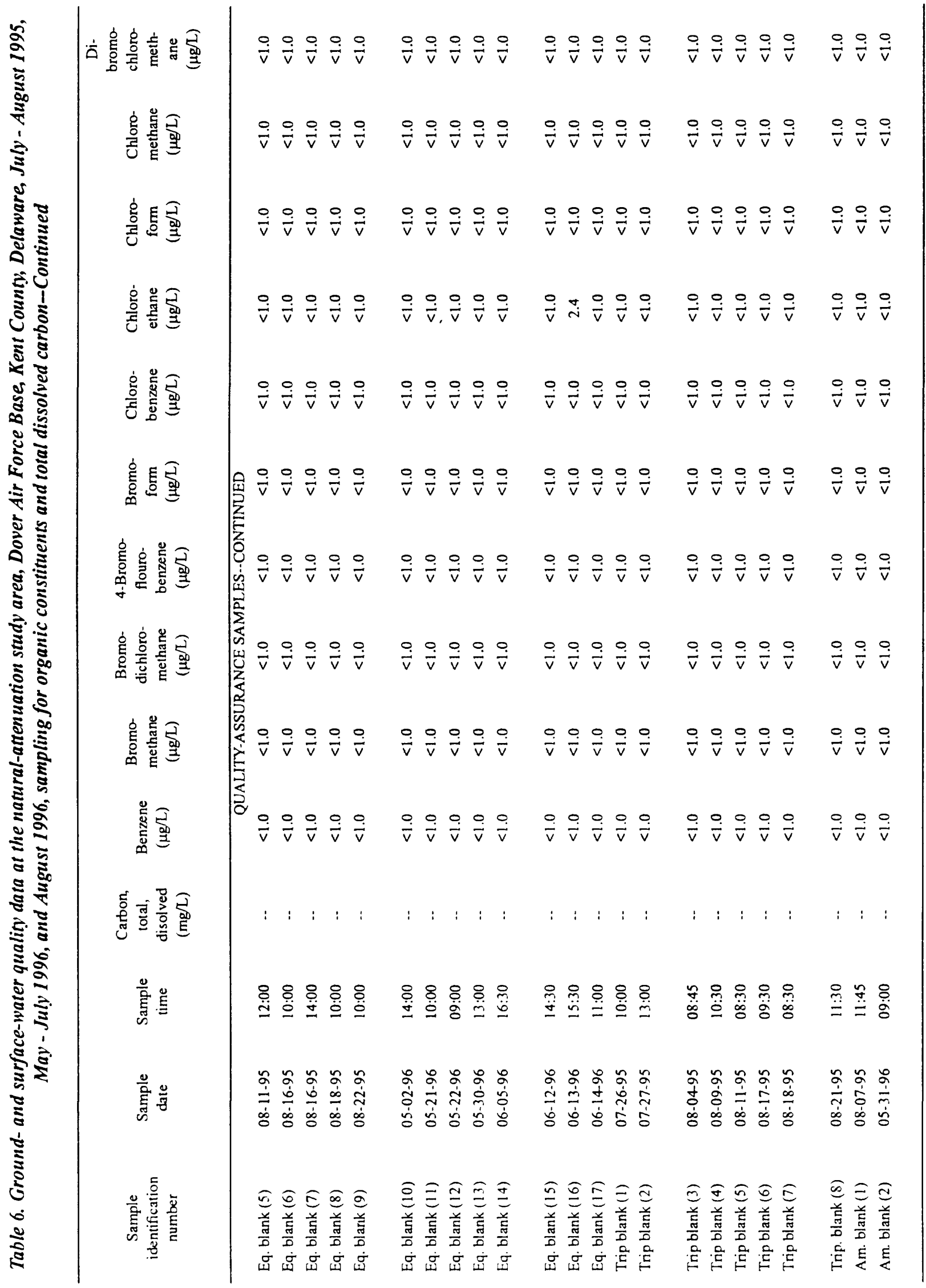




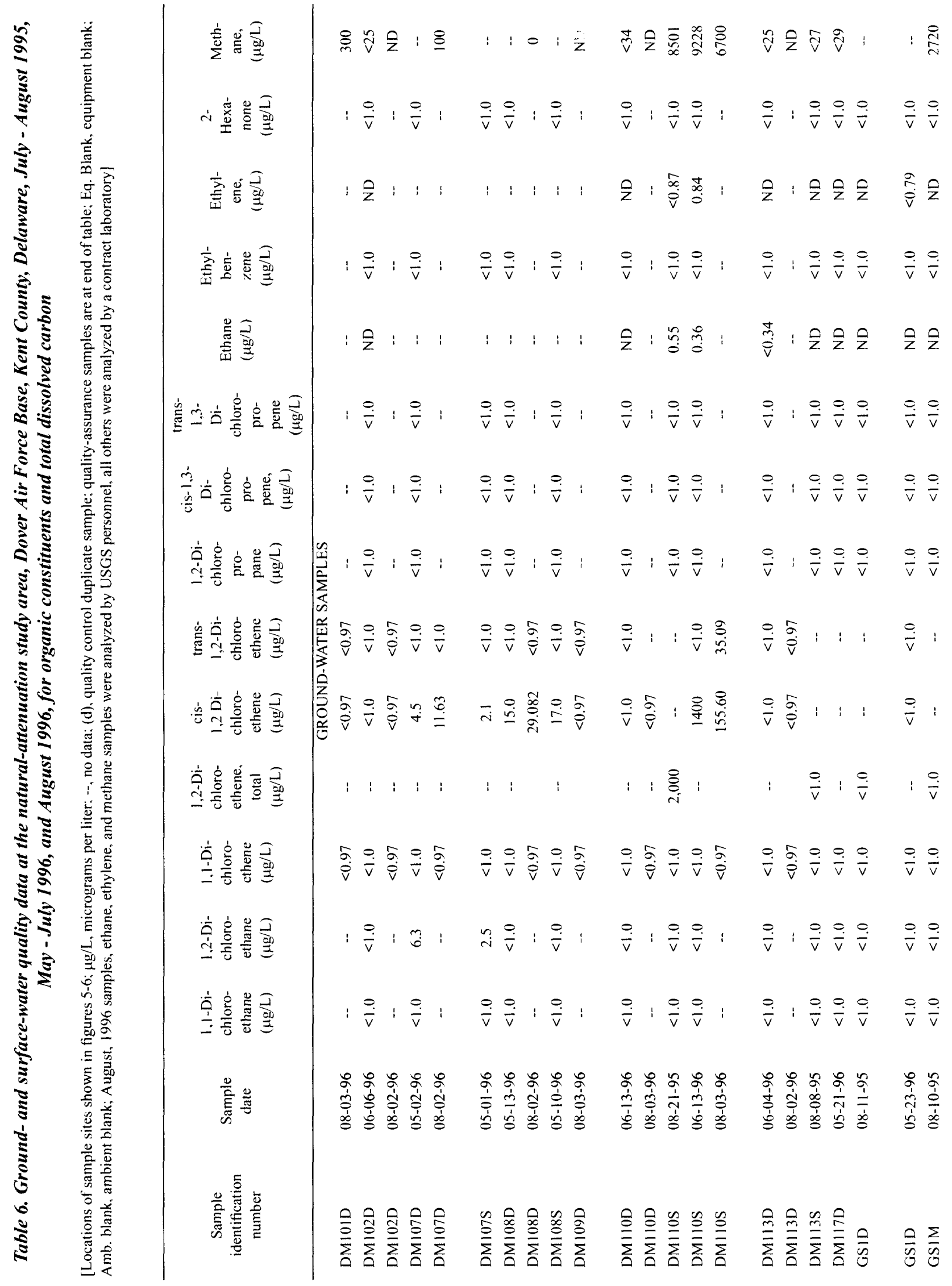




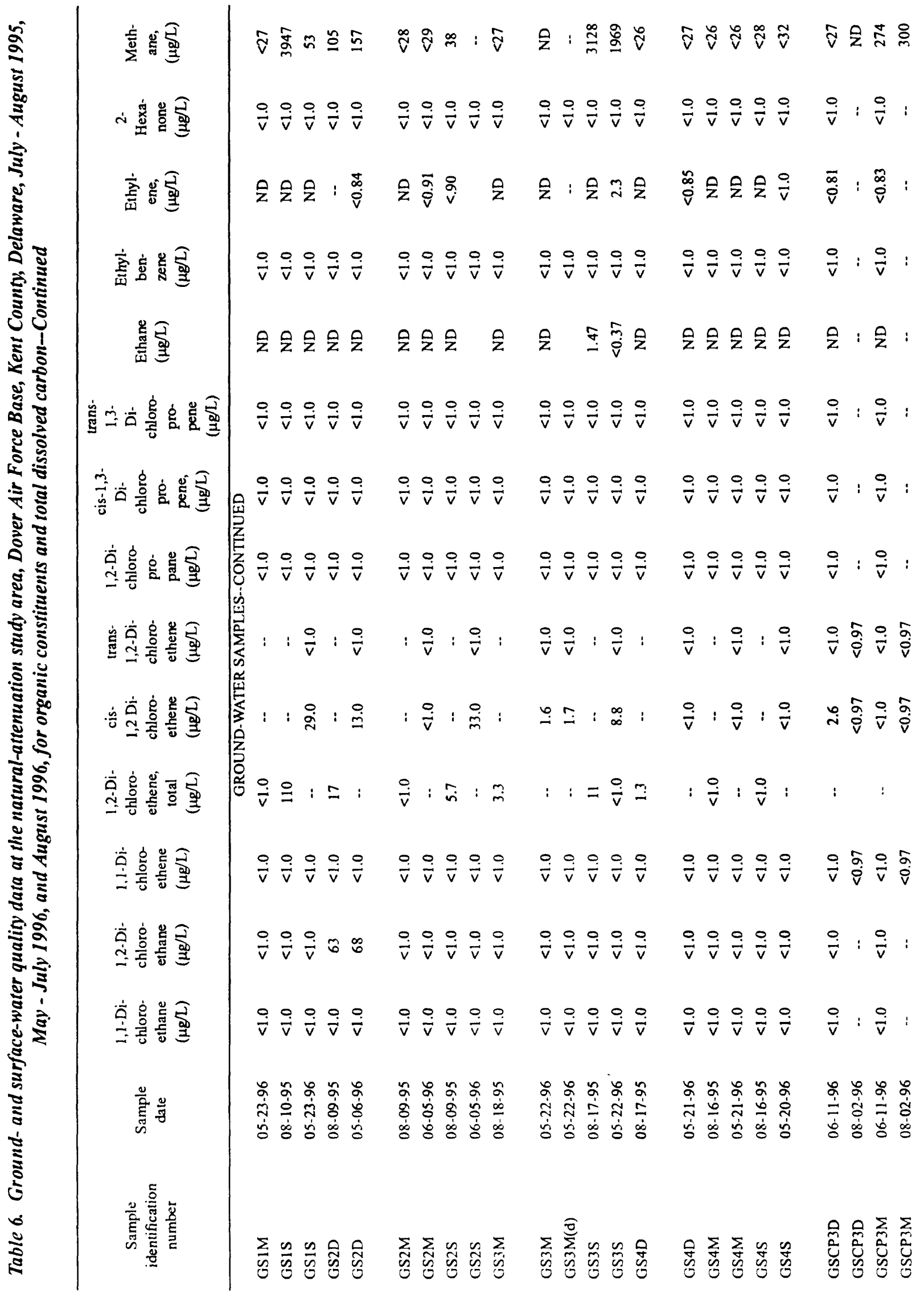




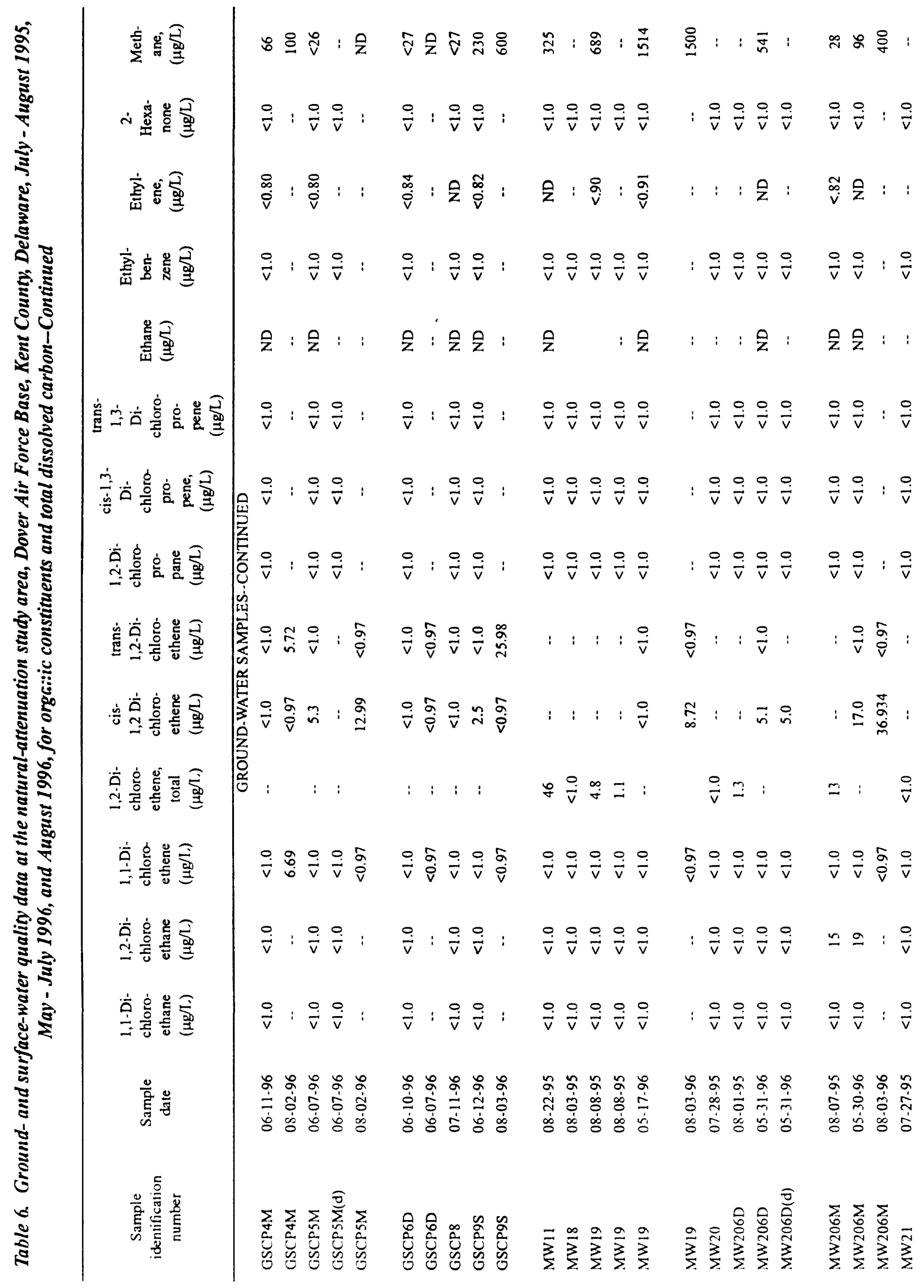




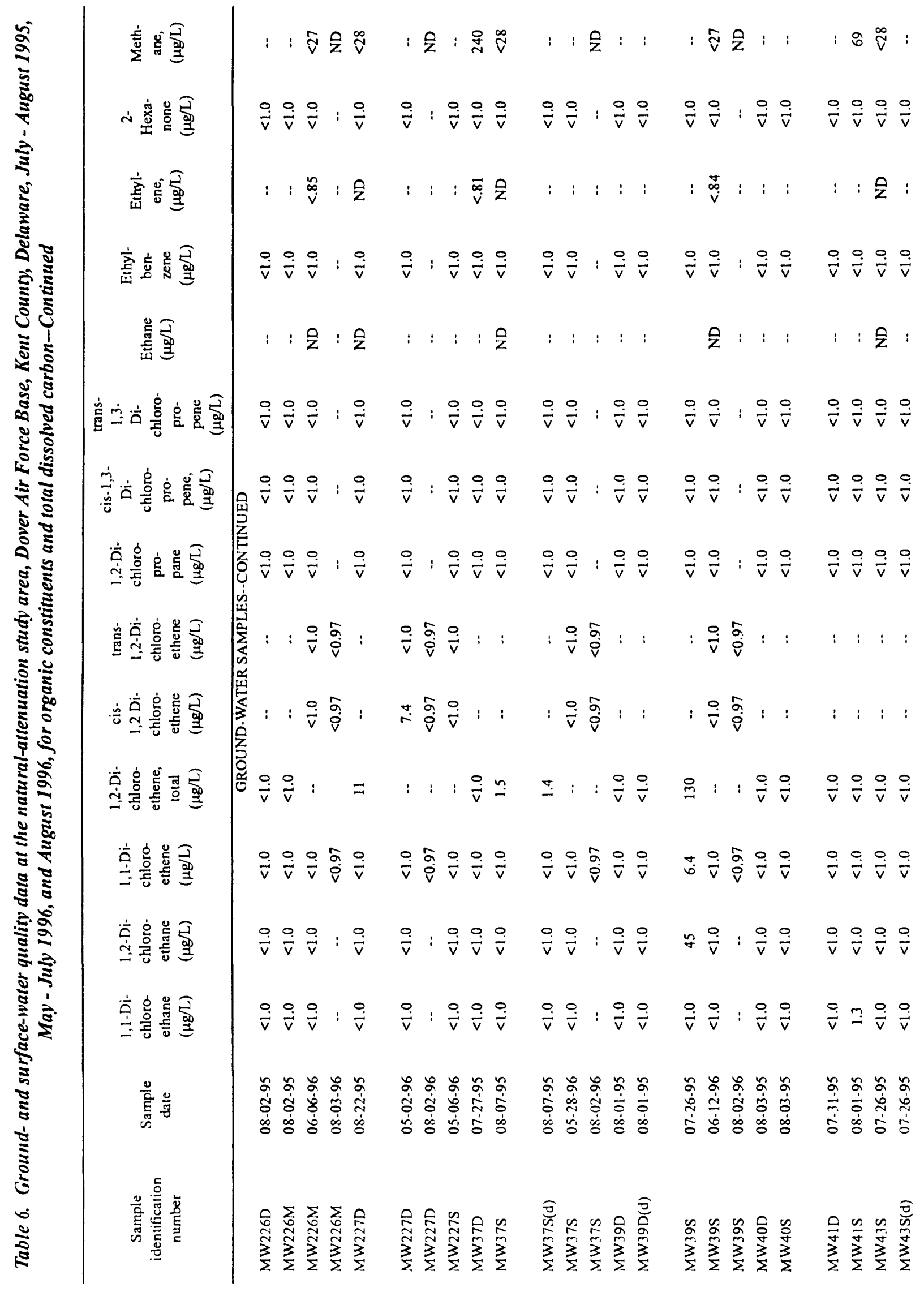




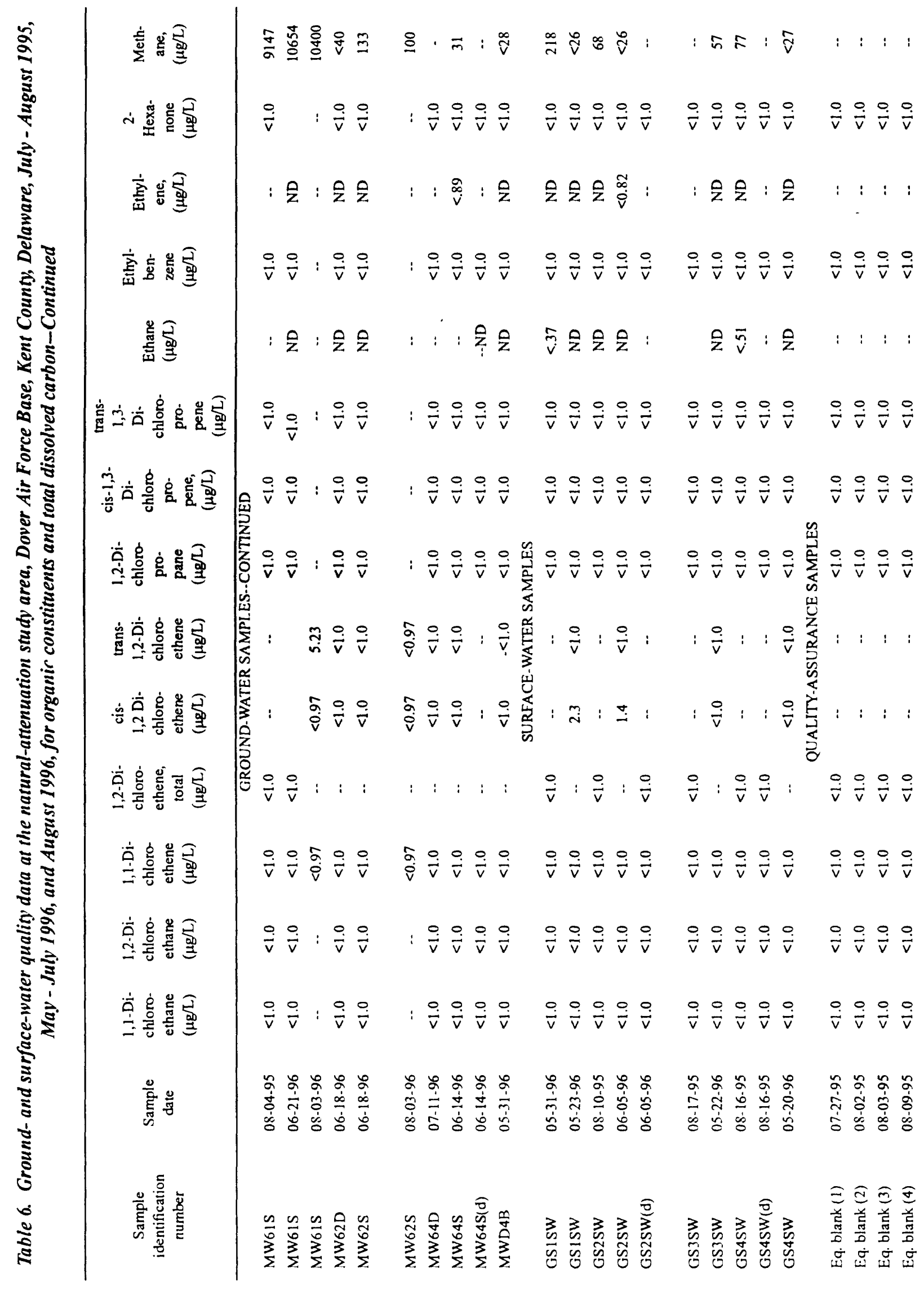




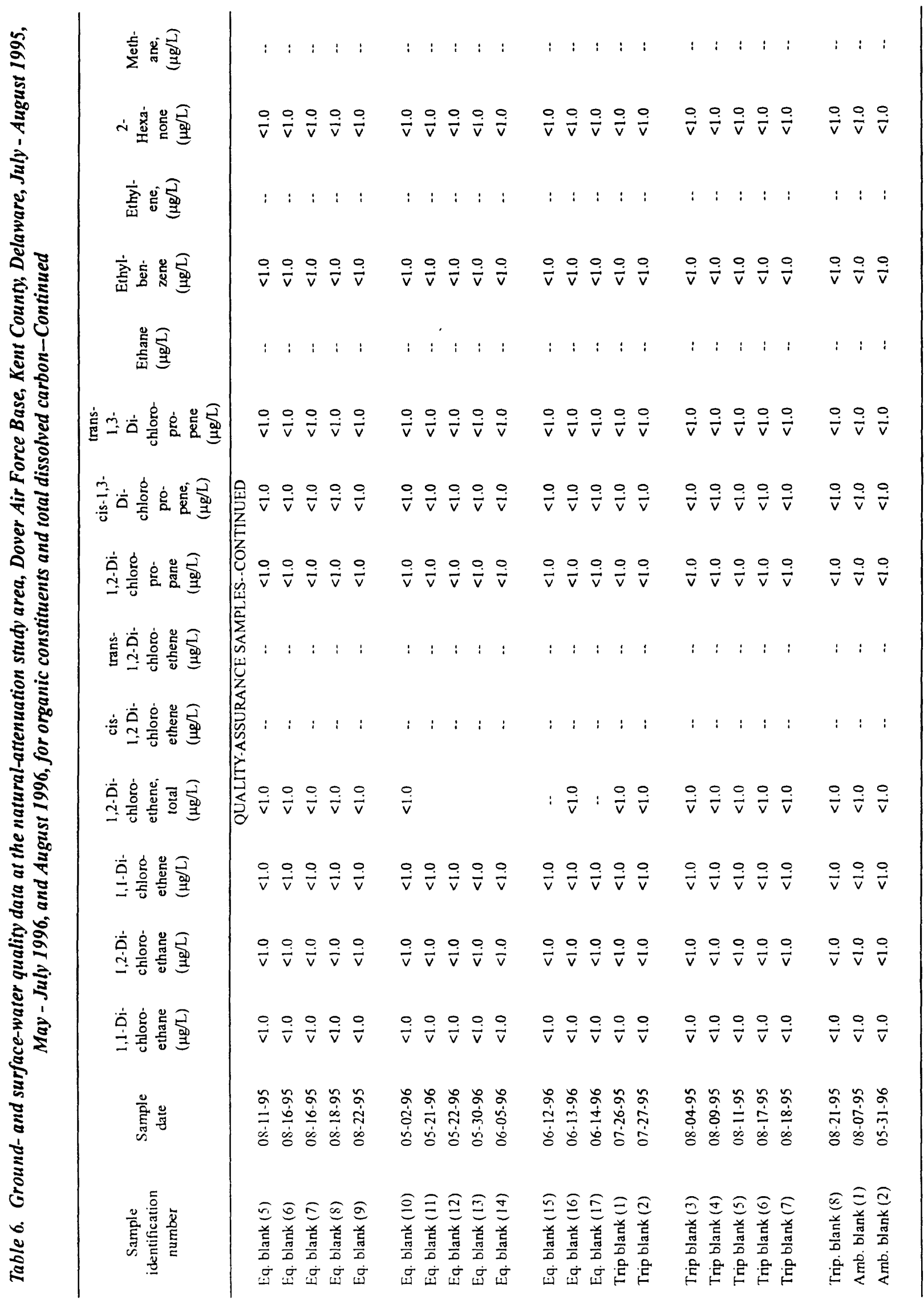




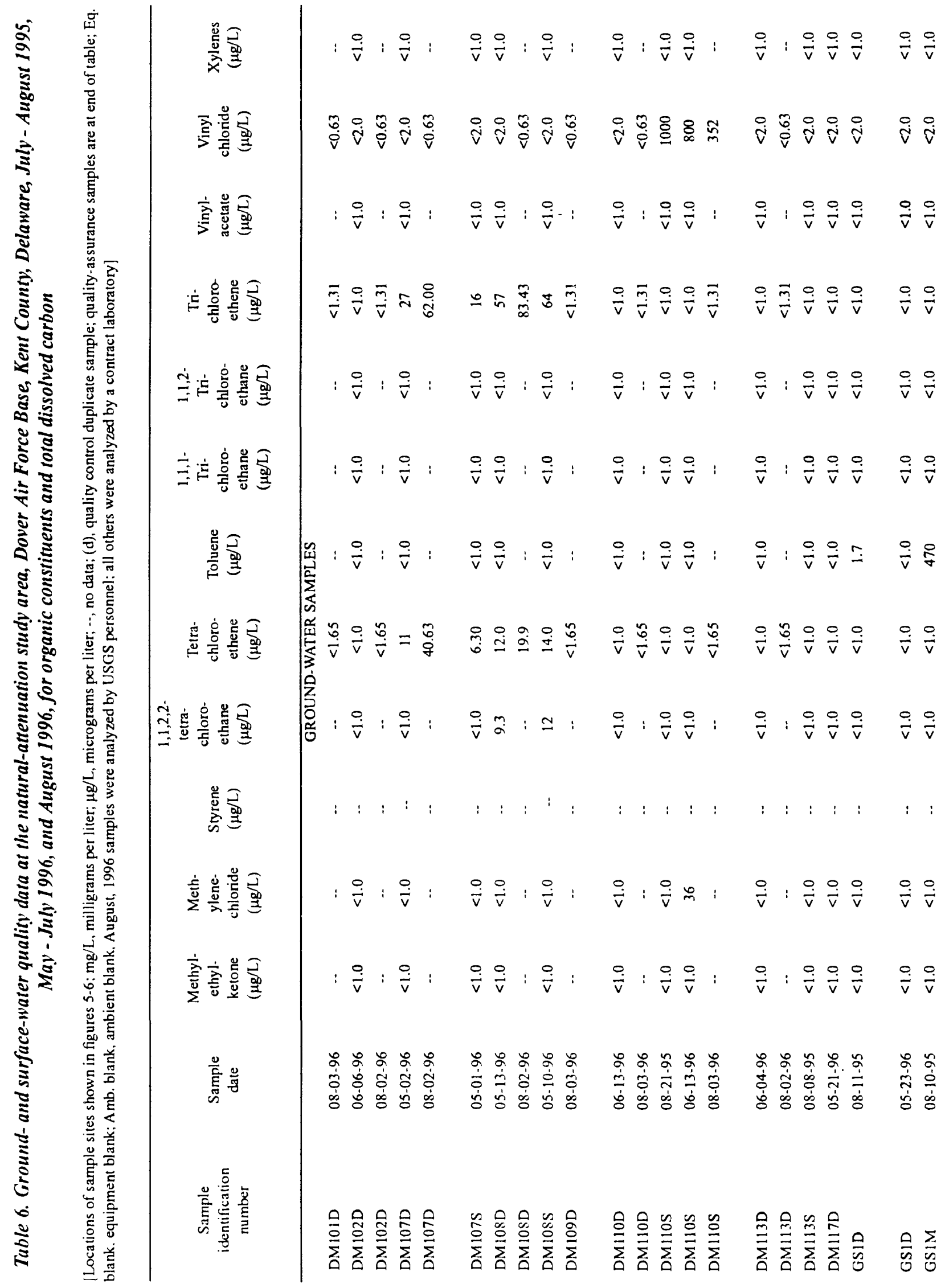




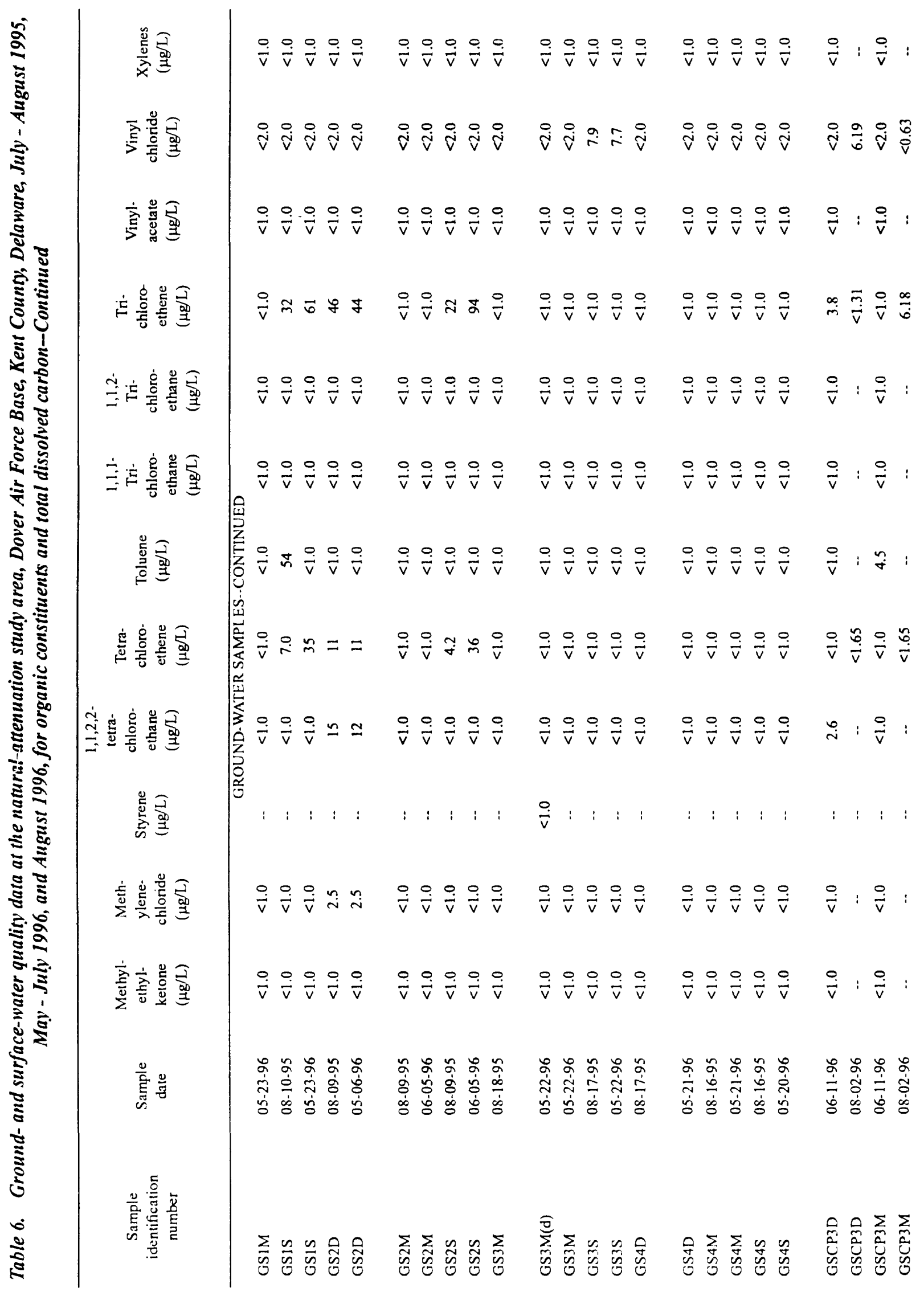




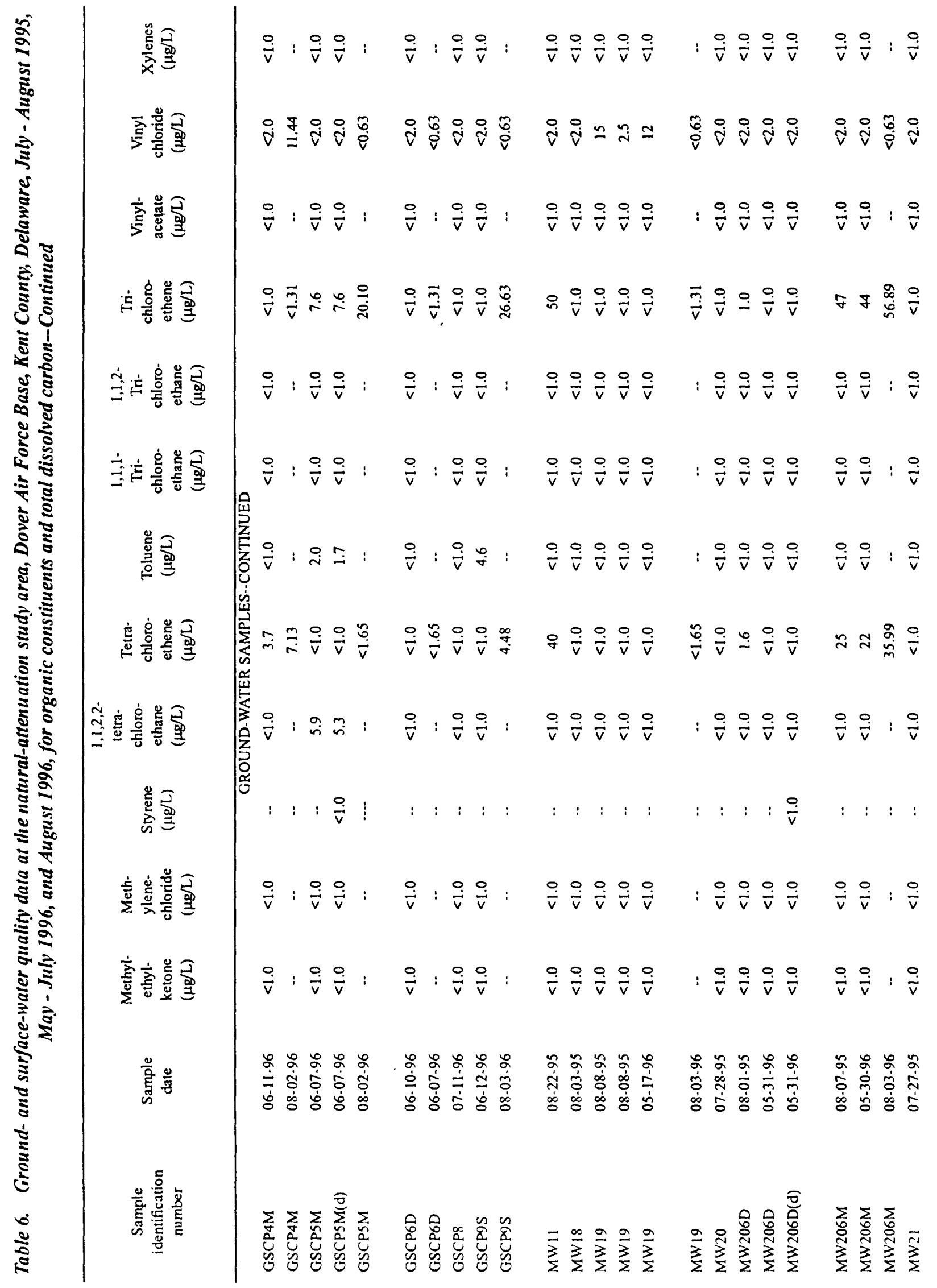




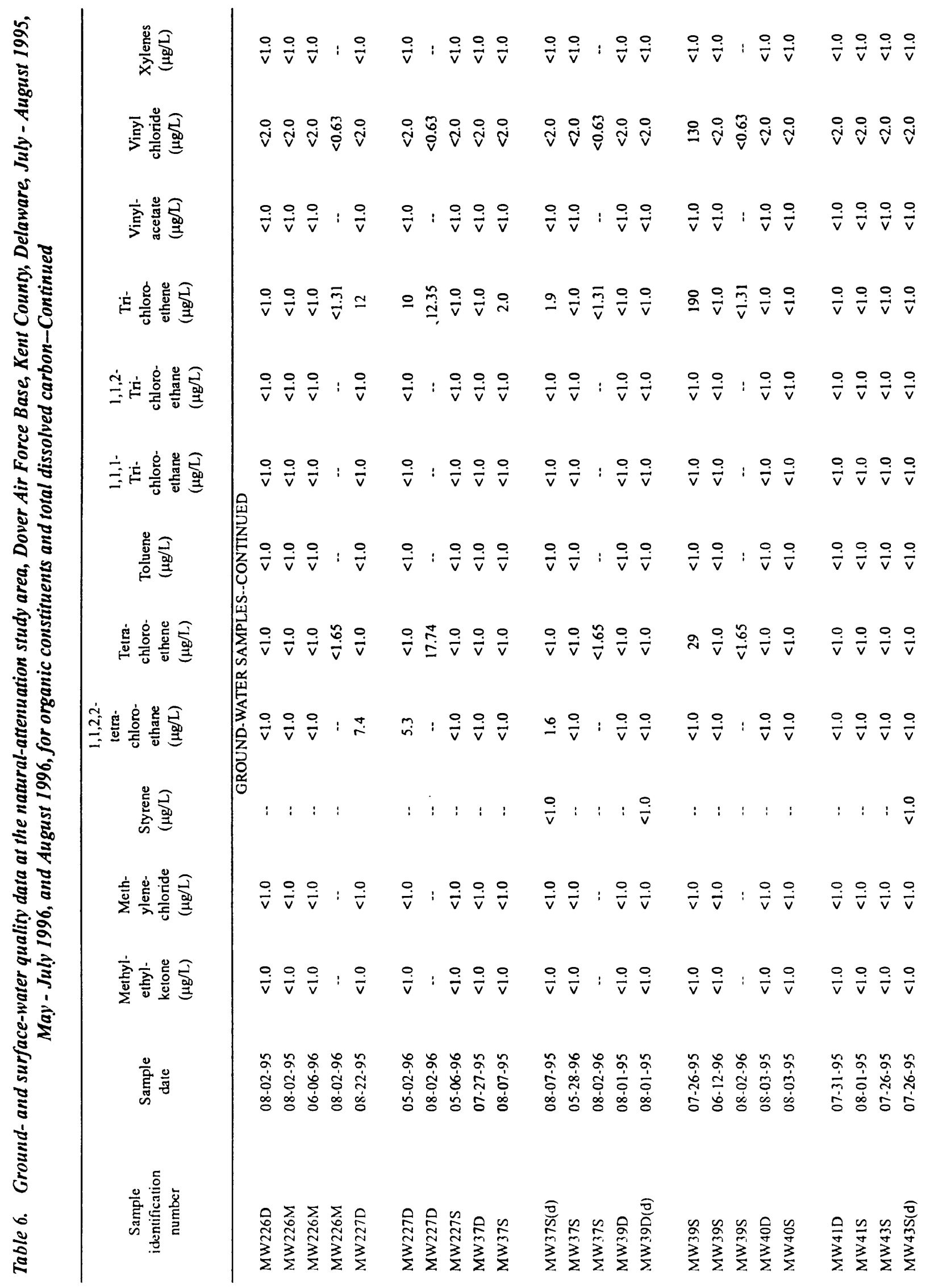




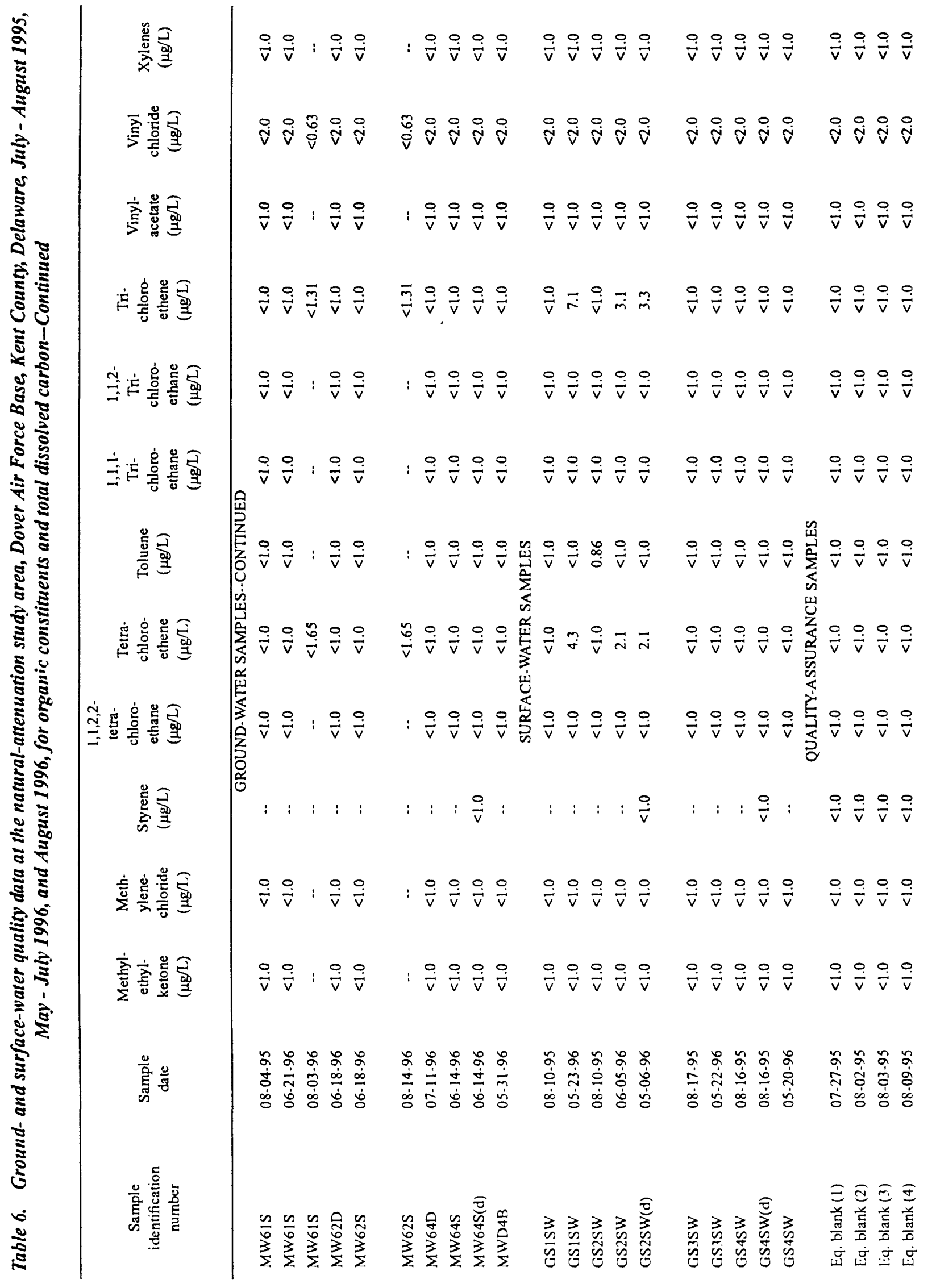




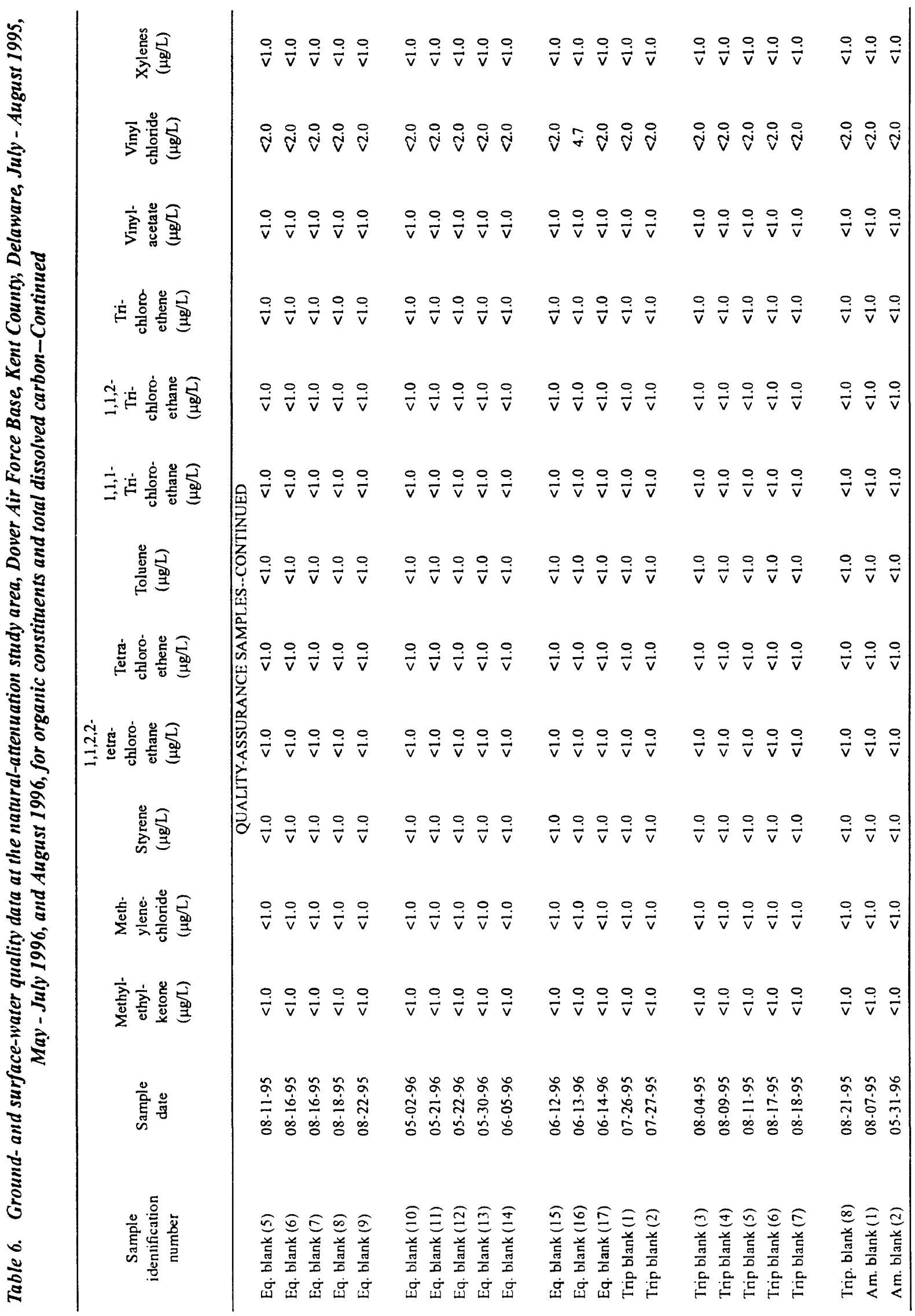


Table 7. Sample and duplicate concentrations, and relative percent differences for four volatile organic compounds at sites where concentrations exceeded the reporting limit, July 1995 through July 1996, Dover Air Force Base, Kent County, Delaware

[ $\mu \mathrm{g} / \mathrm{L}$, micrograms per liter]

\begin{tabular}{lccccc}
\hline \multicolumn{1}{c}{ Site } & Date & Analyte & $\begin{array}{c}\text { Sample } \\
\text { con- } \\
\text { centration } \\
(\mu \mathrm{g} / \mathrm{L})\end{array}$ & $\begin{array}{c}\text { Duplicate } \\
\text { con- } \\
\text { centration } \\
(\mu \mathrm{g} / \mathrm{L})\end{array}$ & $\begin{array}{c}\text { Relative } \\
\text { percent } \\
\text { difference }\end{array}$ \\
\hline MW37S & $08 / 07 / 95$ & 1,2-Dichloroethene,total & 1.5 & 1.4 & 6.9 \\
MW37S & $08 / 07 / 95$ & Trichloroethene & 2 & 1.9 & 5.1 \\
GS3M & $05 / 22 / 96$ & cis-1,2-Dichloroethene & 1.6 & 1.7 & 6.1 \\
MW206D & $05 / 31 / 96$ & cis-1,2-Dichloroethene & 5 & 5.1 & 2 \\
GS2SW & $06 / 05 / 96$ & cis-1,2-Dichloroethene & 1.4 & 1.4 & 0 \\
GS2SW & $06 / 05 / 96$ & Trichloroethene & 3.1 & 3.3 & 6.2 \\
GSCP5M & $06 / 07 / 96$ & $1,1,2,2$-Tetrachloroethane & 5.3 & 5.9 & 10.7 \\
GSCP5M & $06 / 07 / 96$ & cis-1,2-Dichloroethene & 5.3 & 5.3 & 0 \\
GSCP5M & $06 / 07 / 96$ & Trichloroethene & 7.6 & 7.6 & 0 \\
\hline
\end{tabular}


Table 8. Sample and duplicate concentrations, relative percent differences, and summary statistics for methane samples collected from July, 1995 through July, 1996, Dover Air Force Base, Kent County, Delaware

$[\mu \mathrm{g} / \mathrm{L}$, micrograms per liter $]$

\begin{tabular}{|c|c|c|c|c|}
\hline Site & Date & $\begin{array}{c}\text { Sample } \\
\text { concentration } \\
(\mu \mathrm{g} / \mathrm{L})\end{array}$ & $\begin{array}{c}\text { Duplicate } \\
\text { concentration } \\
(\mu \mathrm{g} / \mathrm{L})\end{array}$ & $\begin{array}{l}\text { Relative } \\
\text { percent } \\
\text { difference }\end{array}$ \\
\hline MW39S & $07 / 26 / 95$ & 2,812 & 2,668 & 5.3 \\
\hline MW37D & $07 / 27 / 95$ & 240 & 235 & 2.1 \\
\hline MW21 & $07 / 27 / 95$ & 39 & 34 & 13.7 \\
\hline MW206D & $08 / 01 / 95$ & 38 & 36 & 5.4 \\
\hline MW41S & $08 / 01 / 95$ & 69 & 65 & 6 \\
\hline MW61S & $08 / 04 / 95$ & 9,821 & 9,147 & 7.1 \\
\hline MW19 & $05 / 17 / 96$ & 1,514 & 1,493 & 1.4 \\
\hline GS3S & $05 / 22 / 96$ & 1,969 & 1,877 & 4.8 \\
\hline MW206M & $05 / 30 / 96$ & 96 & 94 & 2.1 \\
\hline MW206D & $05 / 31 / 96$ & 541 & 481 & 11.7 \\
\hline GS2D & $06 / 05 / 96$ & 157 & 144 & 8.6 \\
\hline GSCP4M & $06 / 11 / 96$ & 66 & 63 & 4.7 \\
\hline GSCP3D & $06 / 11 / 96$ & 274 & 263 & 4.1 \\
\hline GSCP9S & $06 / 12 / 96$ & 230 & 223 & 3.1 \\
\hline DM110S & $06 / 13 / 96$ & 9,228 & 9,951 & 7.5 \\
\hline MW64S & $06 / 14 / 96$ & 31 & 29 & 6.7 \\
\hline MW61S & $06 / 21 / 96$ & 10,654 & 10,106 & 5.3 \\
\hline Number & & 17 & 17 & -- \\
\hline Median & & 240 & 235 & 5.3 \\
\hline Maximum & & 10,654 & 10,106 & 13.7 \\
\hline Minimum & & 31 & 29 & 1.4 \\
\hline
\end{tabular}


Table 9. Sample and duplicate concentrations, relative percent differences, and summary statistics for hydrogen samples collected in August, 1996, Dover Air Force Base, Kent County, Delaware

[nmol/L, nanomoles per liter]

\begin{tabular}{lccc}
\hline & $\begin{array}{c}\text { Sample } \\
\text { Soncentration } \\
(\mathrm{nmol} / \mathrm{L})\end{array}$ & $\begin{array}{c}\text { Duplicate } \\
\text { concentration } \\
(\mathrm{nmol} / \mathrm{L})\end{array}$ & $\begin{array}{c}\text { Relative } \\
\text { percent } \\
\text { difference }\end{array}$ \\
\hline GSCP5 & 1.1 & 0.92 & 17.8 \\
GSCP6D & 5.6 & 5.4 & 3.6 \\
GSCP9S & 3 & 2.6 & 14.3 \\
MW19 & 3.5 & 3.4 & 2.9 \\
MW37S & 1.3 & 1.4 & 7.4 \\
MW39S & 2.2 & 2.6 & 16.7 \\
MW61S & 2.7 & 2.8 & 3.6 \\
MW206M & 3.7 & 3.9 & 5.3 \\
MW226M & .36 & .3 & 18.2 \\
MW227D & .79 & 1 & 23.5 \\
DM102D & 1.1 & .76 & 36.6 \\
DM108D & 1.3 & 1.4 & 7.4 \\
DM109D & 21.4 & 21 & 1.9 \\
DM110S & .73 & .69 & 5.6 \\
DM113D & 7.1 & 8.5 & 17.9 \\
Number & & & 7.9 \\
Median & 15 & 15 & -- \\
Maximum & 2.2 & 2.6 & 7.9 \\
Minimum & .36 & 21 & \\
\hline & & .3 & \\
\hline
\end{tabular}




\begin{abstract}
APPENDLX
Geophysical logs at the natural-attenuation study area, Dover Air Force Base, Kent County, Delaware, for wells:
\end{abstract}

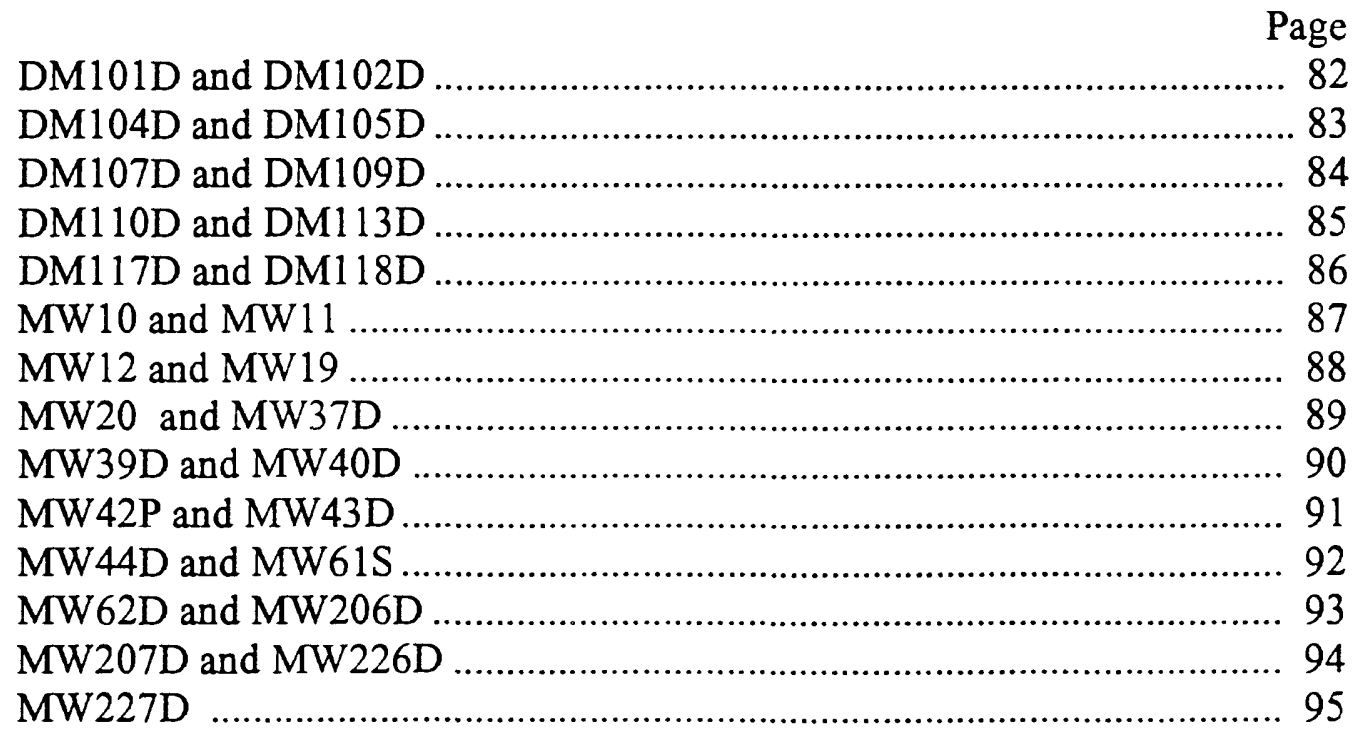

(NGamma = Natural gamma log; Conduct $=$ Electro-magnetic conductivity log; $\mathrm{CPS}=$ counts per second $\mathrm{mS} / \mathrm{m}=$ millisiemens per meter $\theta=$ curve of Conduct $\log$ in that area is affected by metal near the well casing, not lithologic or water-quality changes) 

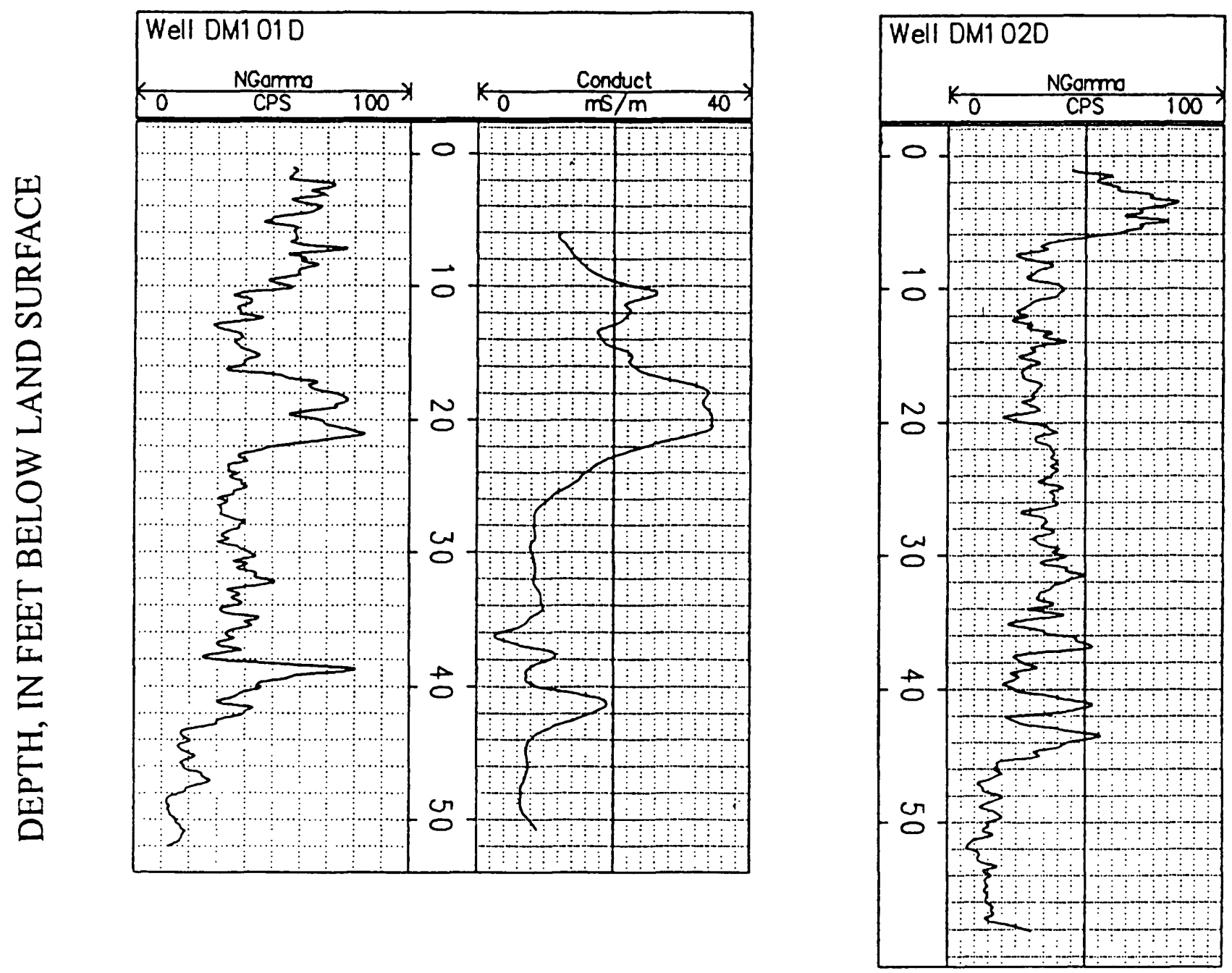

Geophysical logs at the natural-attenuation study area, Dover Air Force Base, Kent County, Delaware, for wells DM101D and DM102D. 

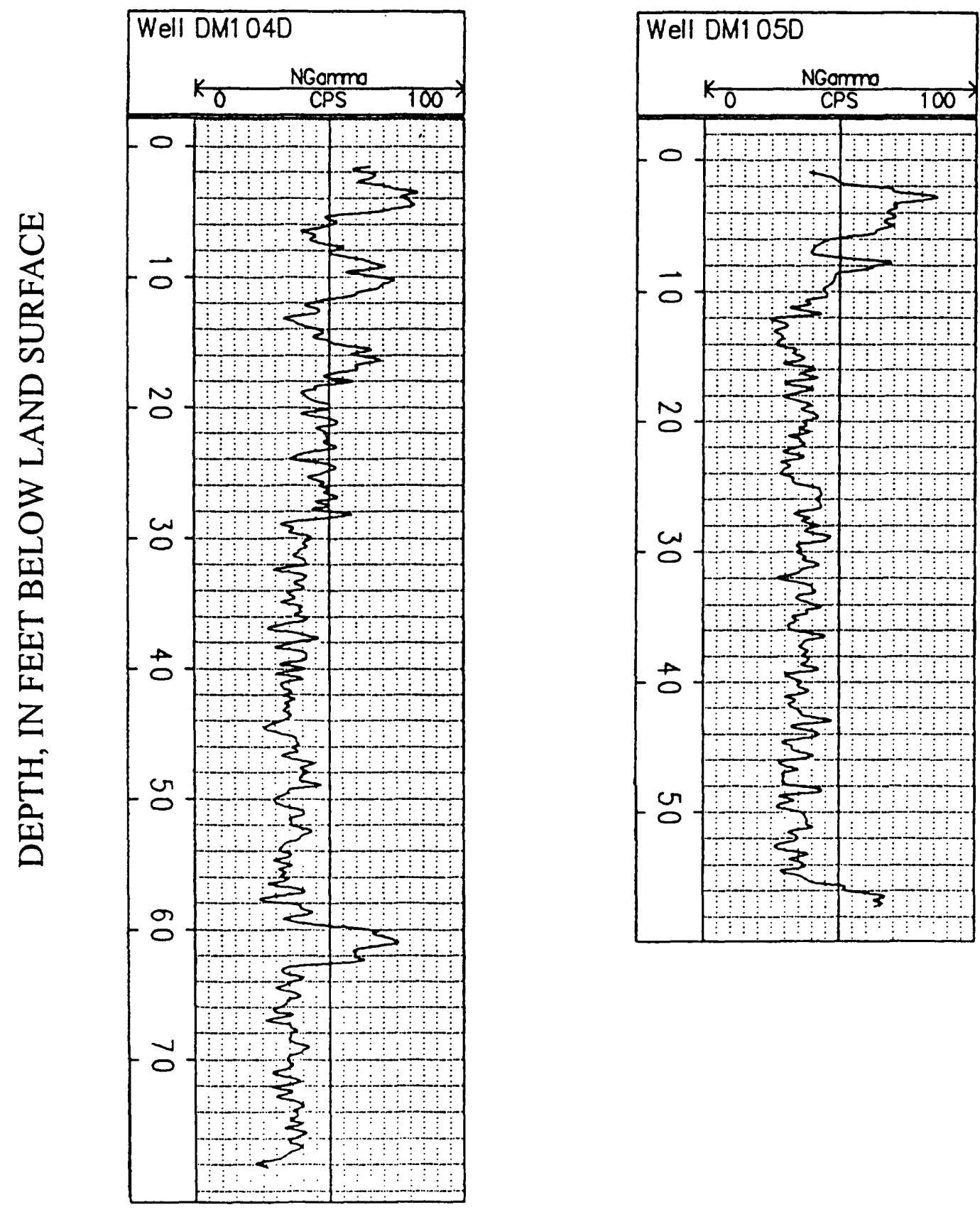

Geophysical logs at the natural-attenuation study area, Dover Air Force Base, Kent County, Delaware, for wells DM104D and DM105D. 

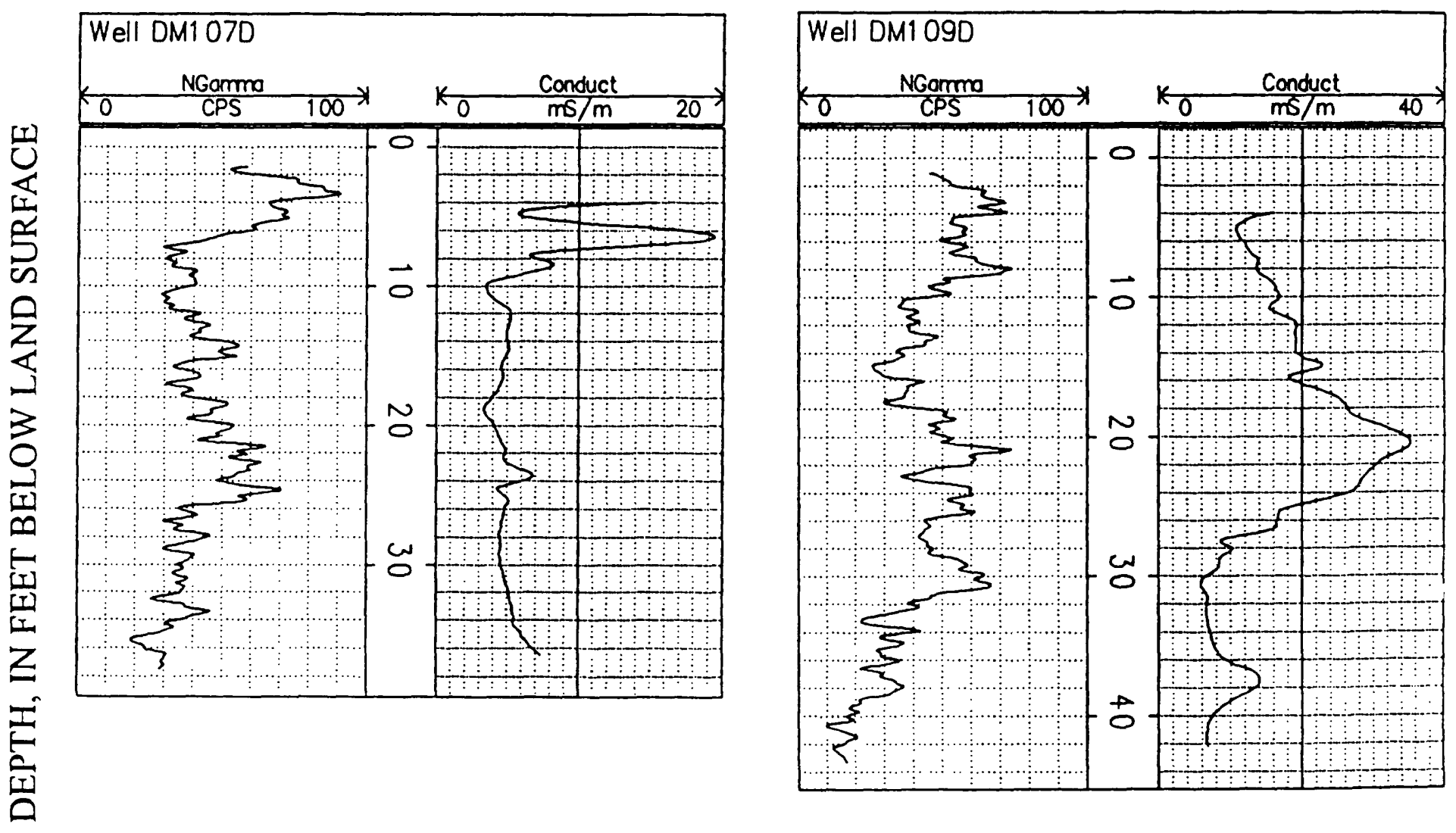

Geophysical logs at the natural-attenuation study area, Dover Air Force Base, Kent County, Delaware, for wells DM107D and DM109D. 

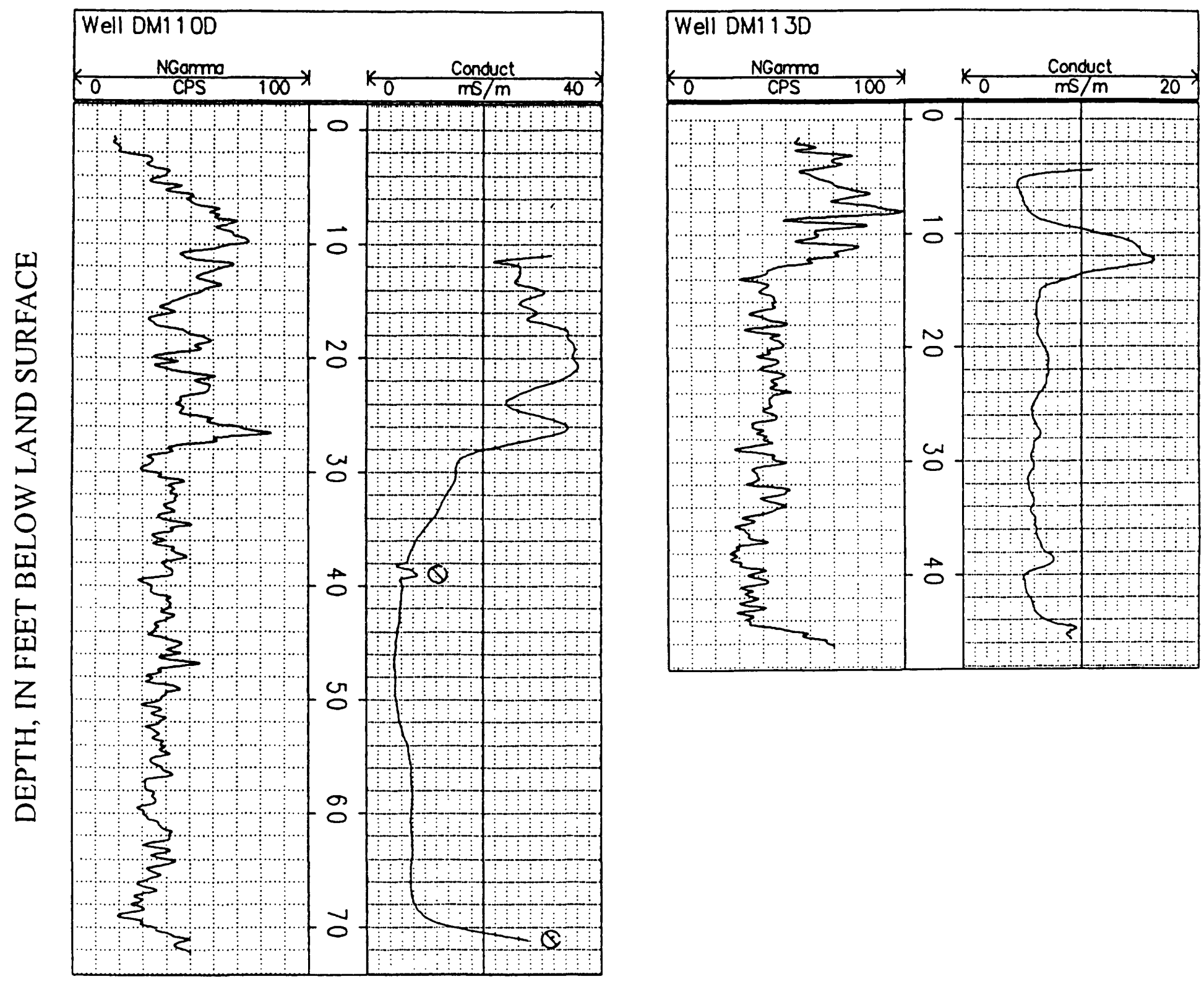

Geophysical logs at the natural-attenuation study area, Dover Air Force Base, Kent County, Delaware, for wells DM110D and DM113D. 

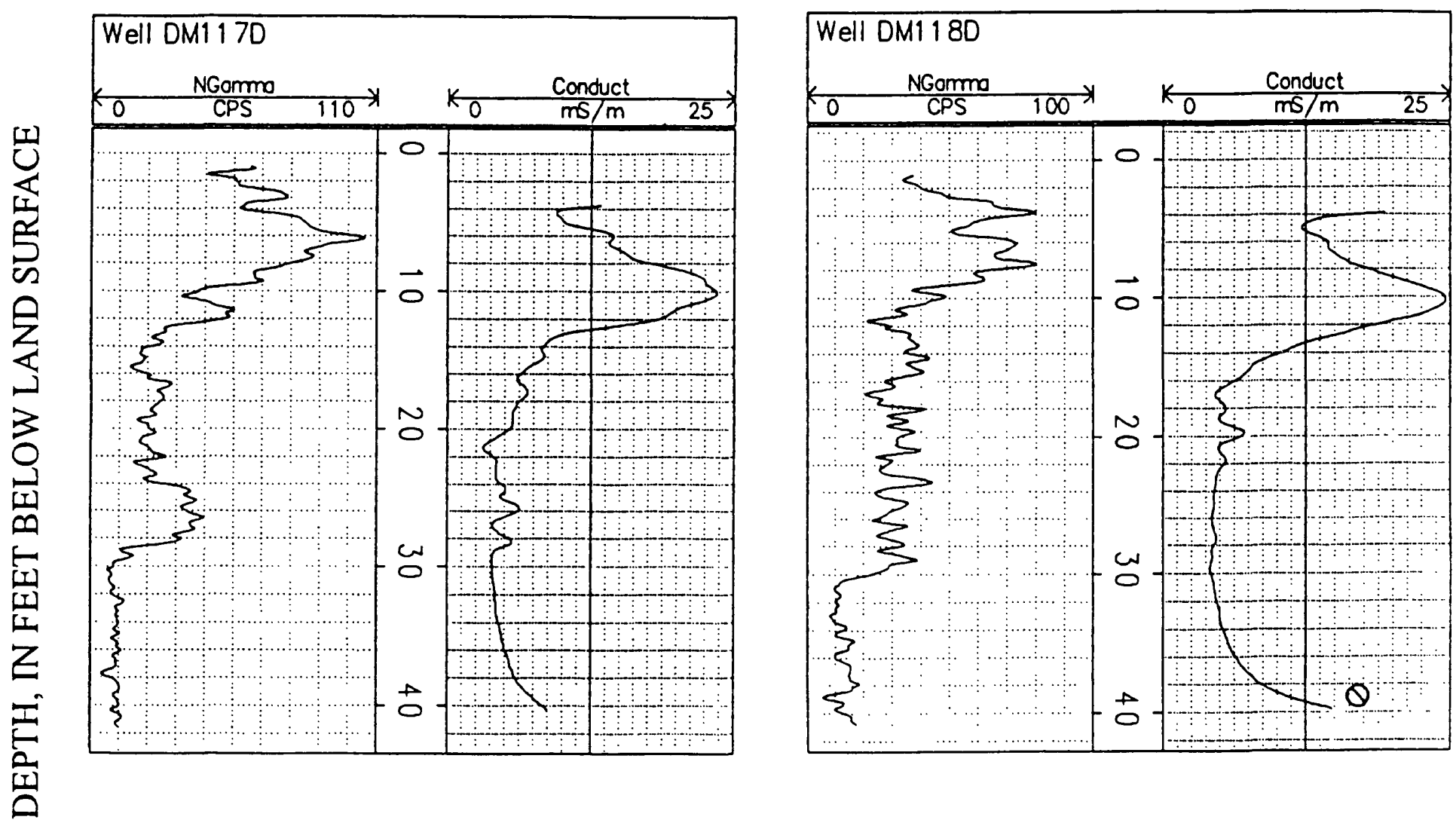

Geophysical logs at the natural-attenuation study area, Dover Air Force Base, Kent County, Delaware, for wells DM117D and DM118D. 

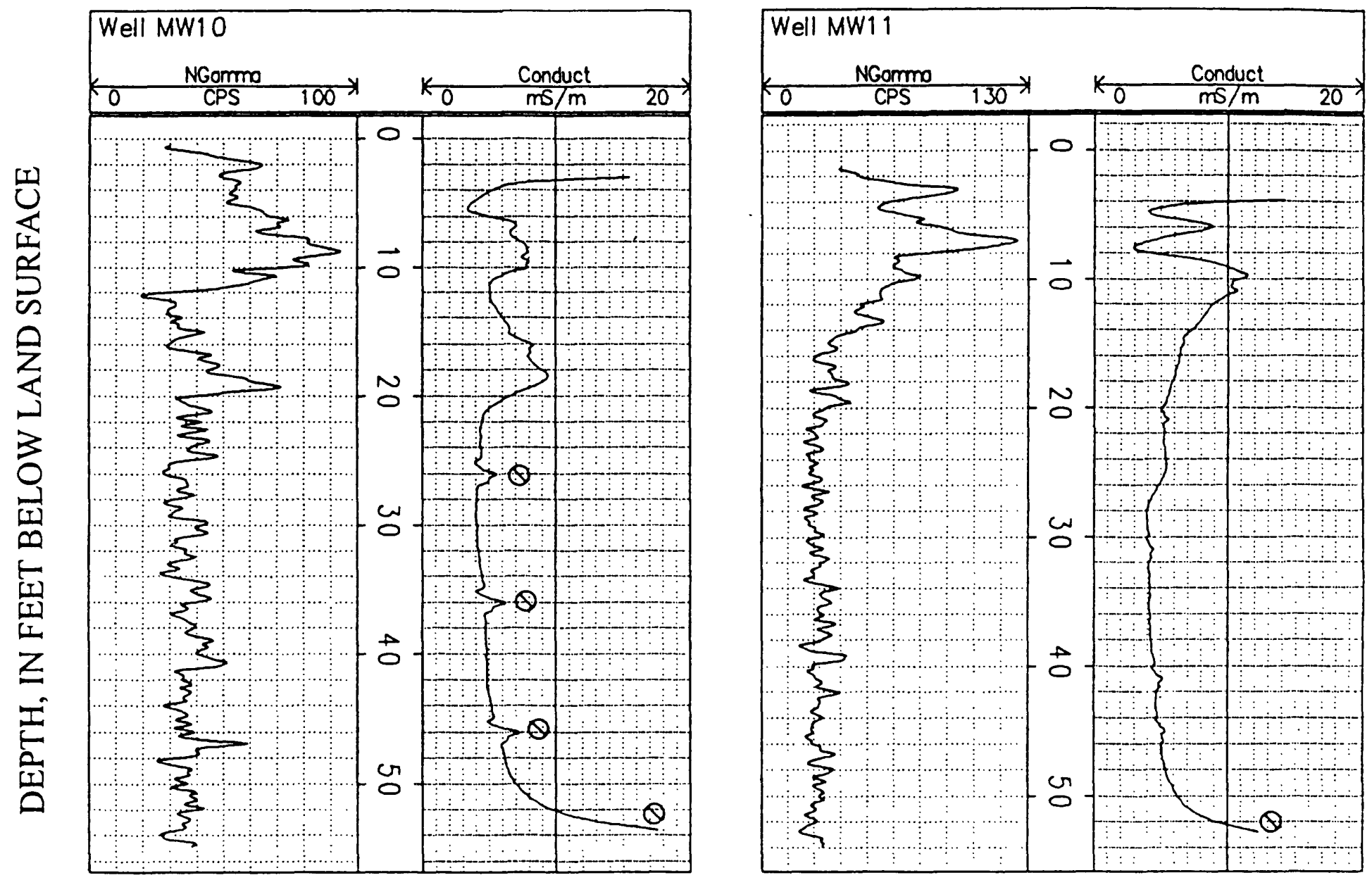

Geophysical logs at the natural-attenuation study area, Dover Air Force Base, Kent County, Delaware, for wells MW10 and MW11. 

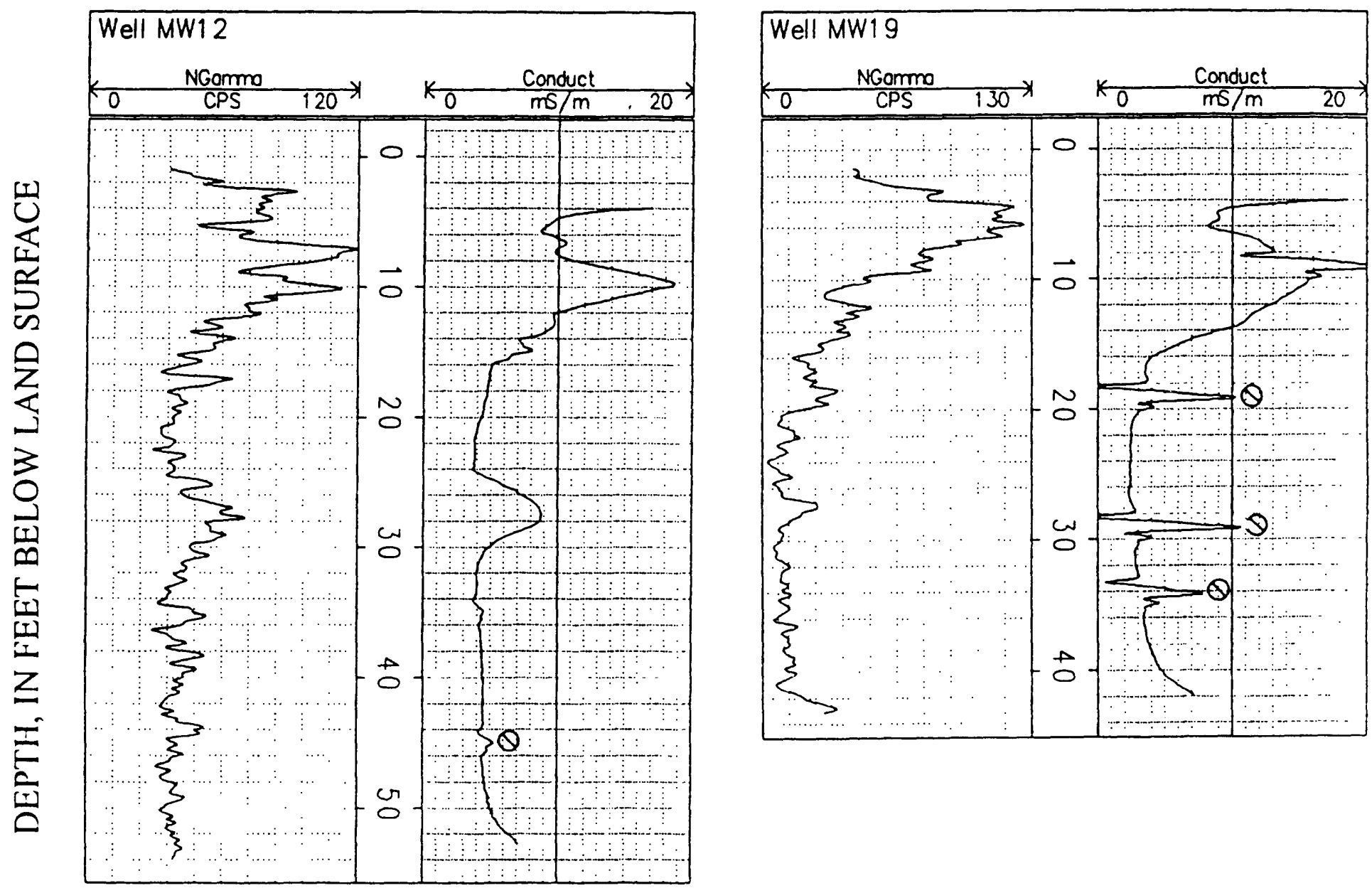

Geophysical logs at the natural-attenuation study area, Dover Air Force Base, Kent County. Delaware, for wells MW12 and MW19. 

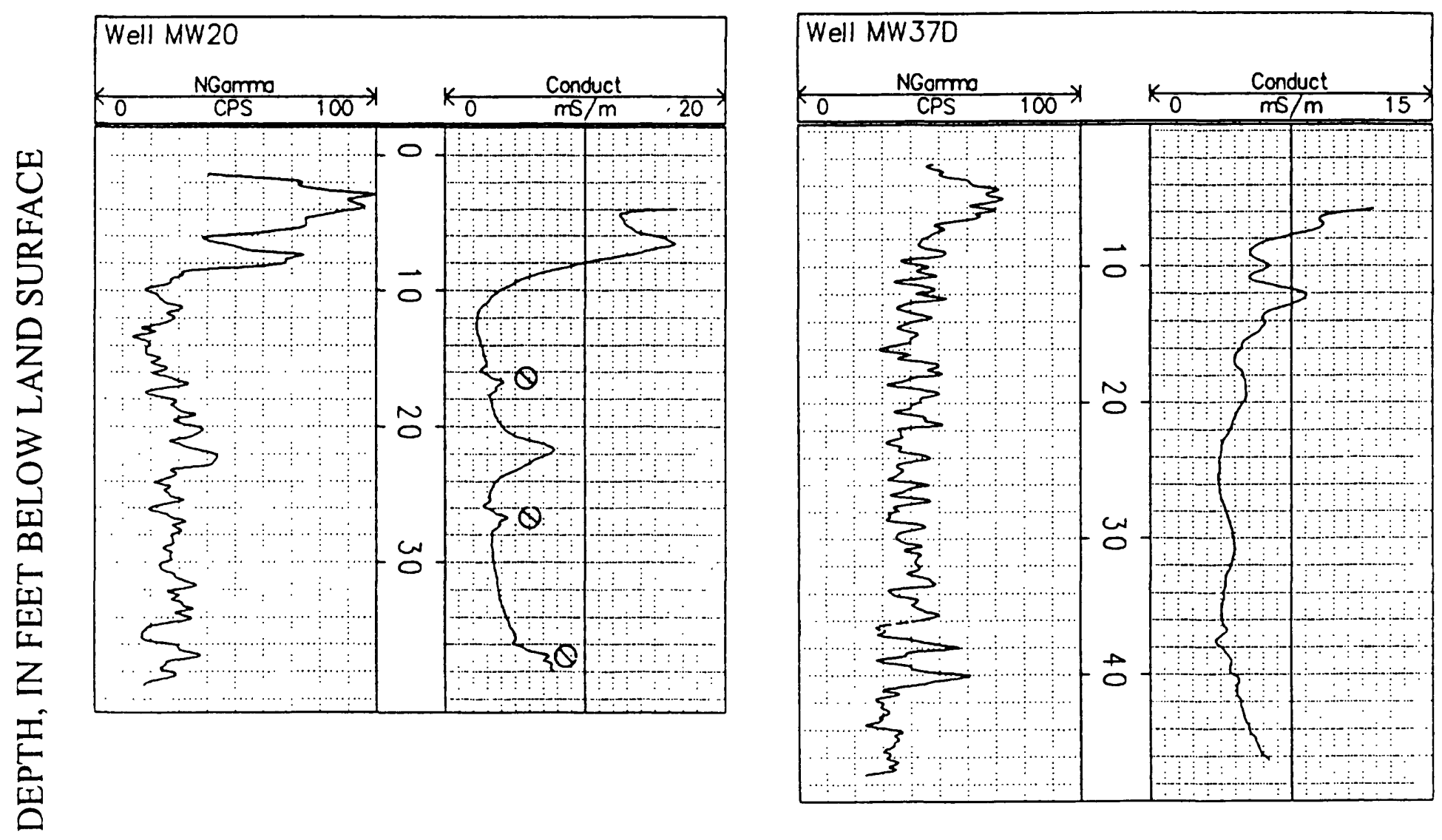

Geophysical logs at the natural-attenuation study area, Dover Air Force Base, Kent County, Delaware, for wells MW20 and MW37D. 

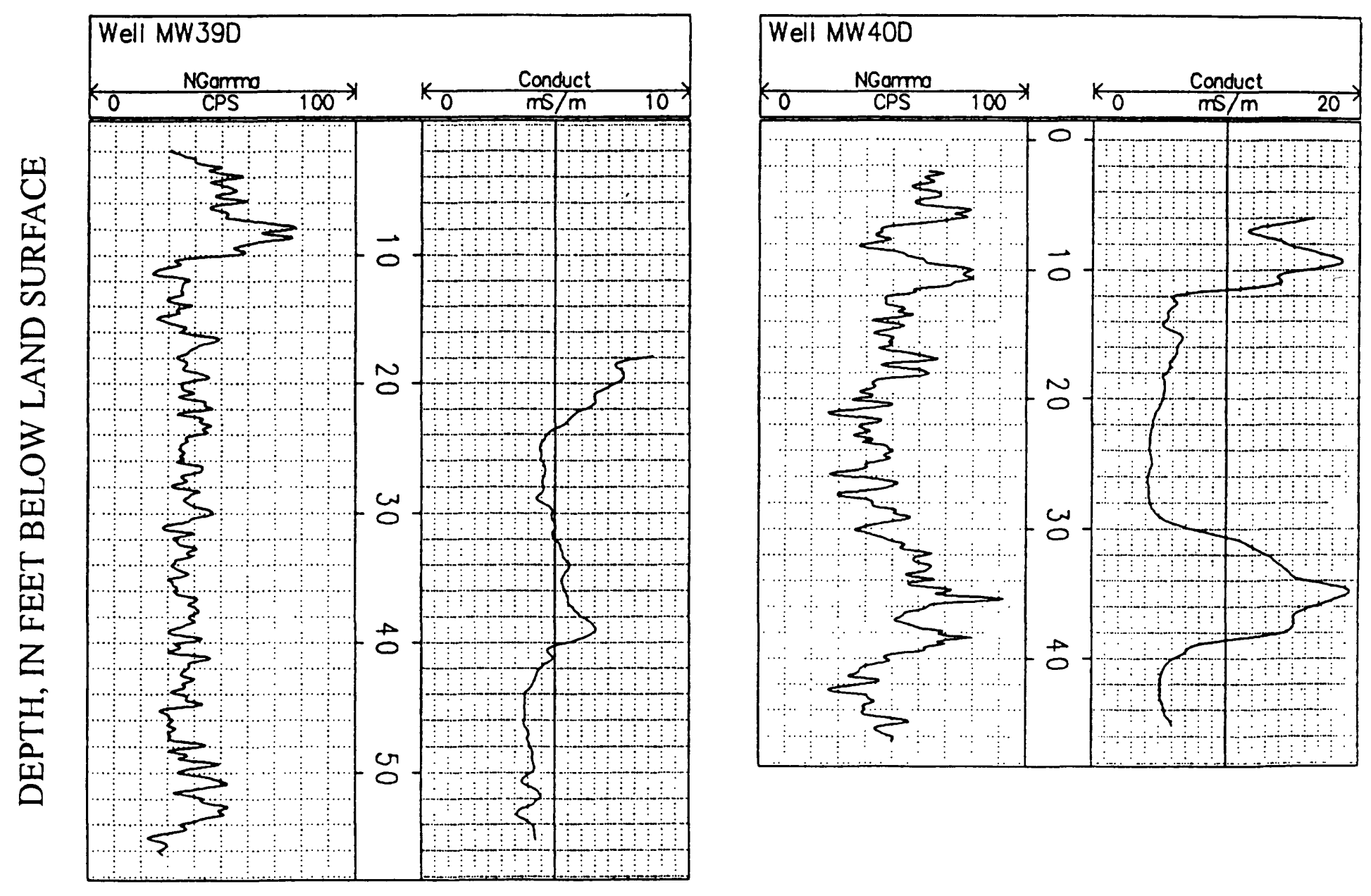

Geophysical logs at the natural-attenuation study area, Dover Air Force Base, Kent County, Delaware, for wells MW39D and MW40D. 

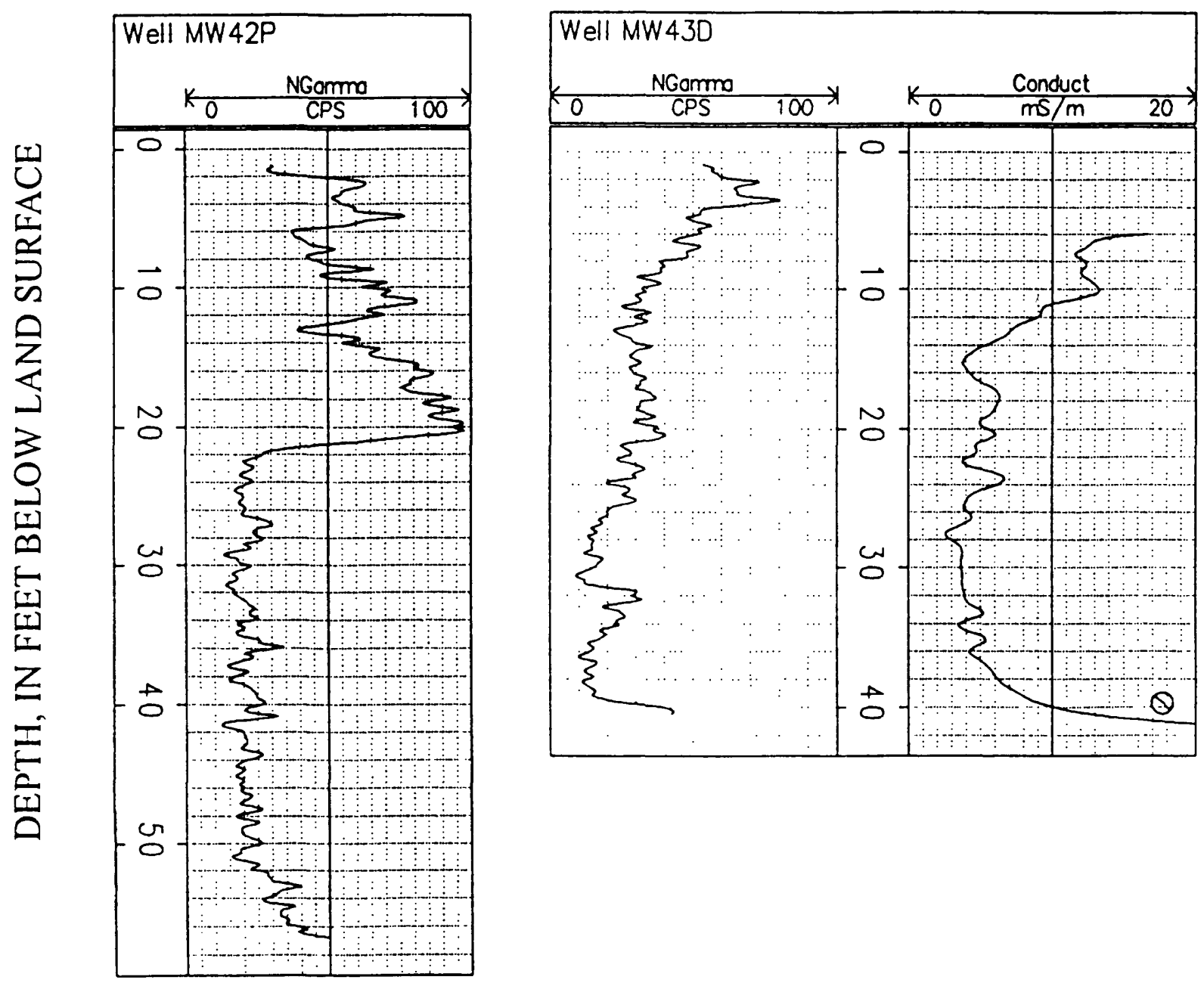

Geophysical logs at the natural-attenuation study area, Dover Air Force Base, Kent County, Delaware, for wells MW42P and MW43D. 

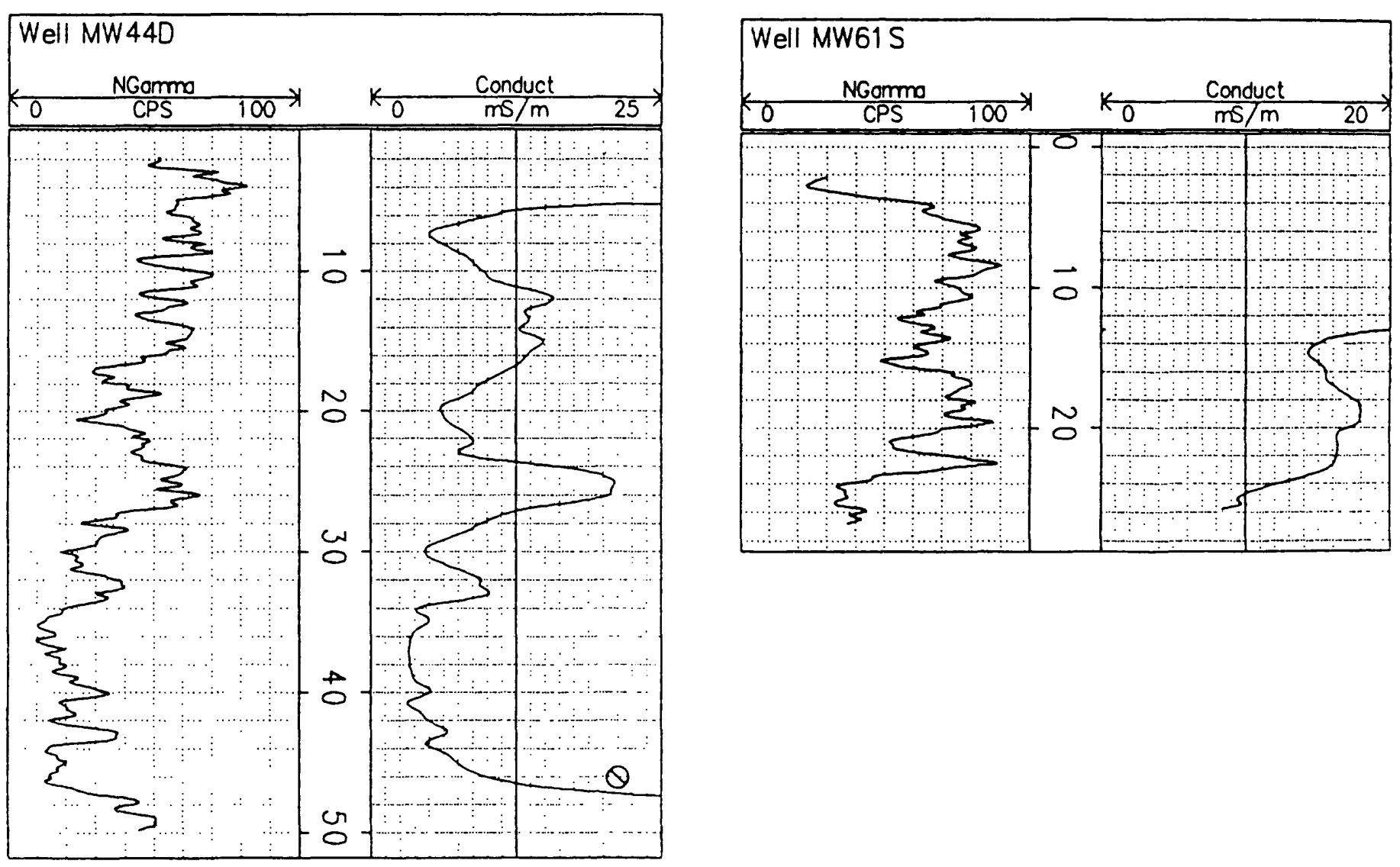

Geophysical logs at the natural-attenuation study area, Dover Air Force Base, Kent County, Delaware, for wells MW44D and MW61S. 

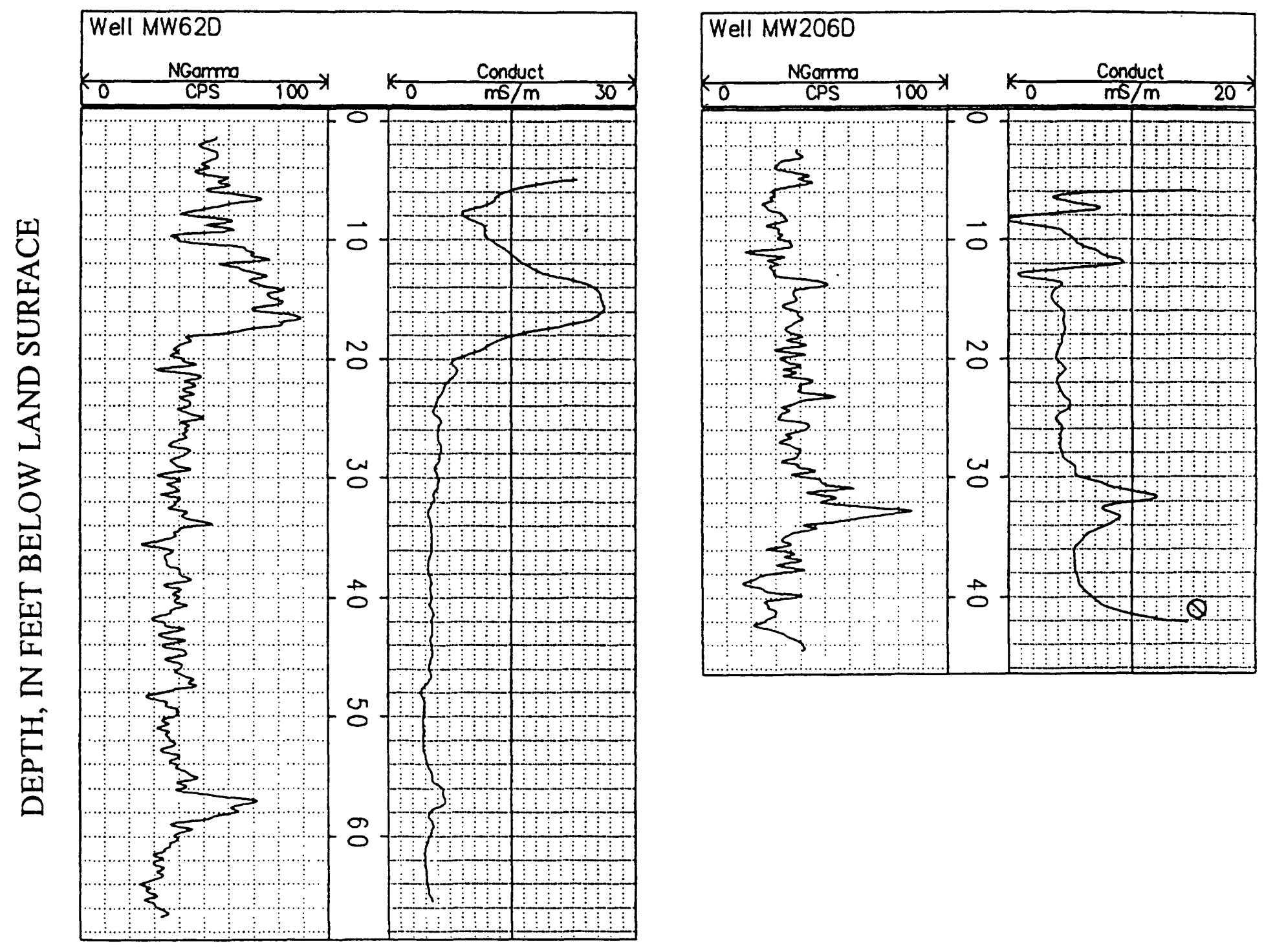

Geophysical logs at the natural-attenuation study area, Dover Air Force Base, Kent County, Delaware, for wells MW62D and MW206D. 

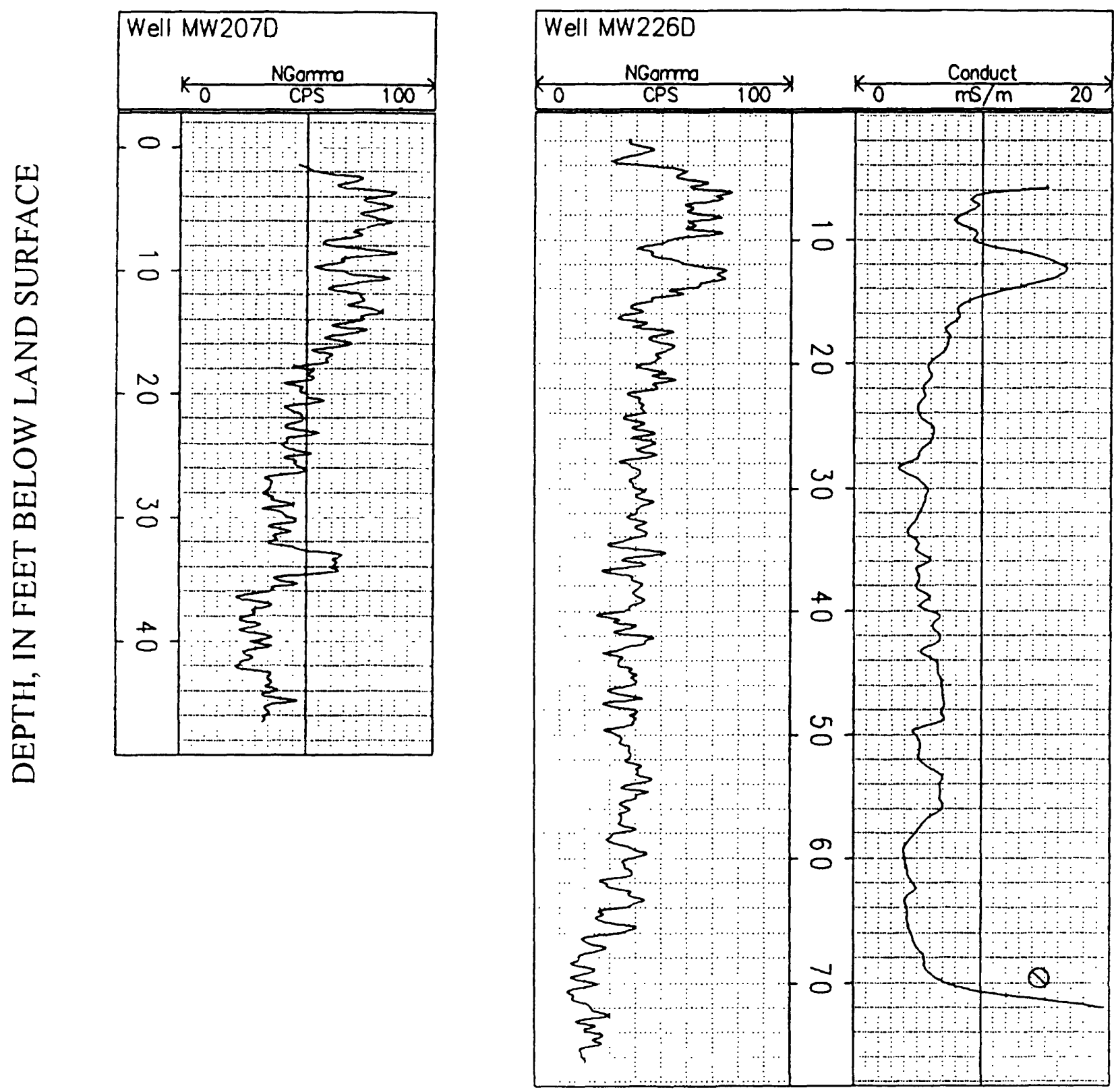

Geophysical logs at the natural-attenuation study area, Dover Air Force Base, Kent County, Delaware, for wells MW207D and MW226D. 


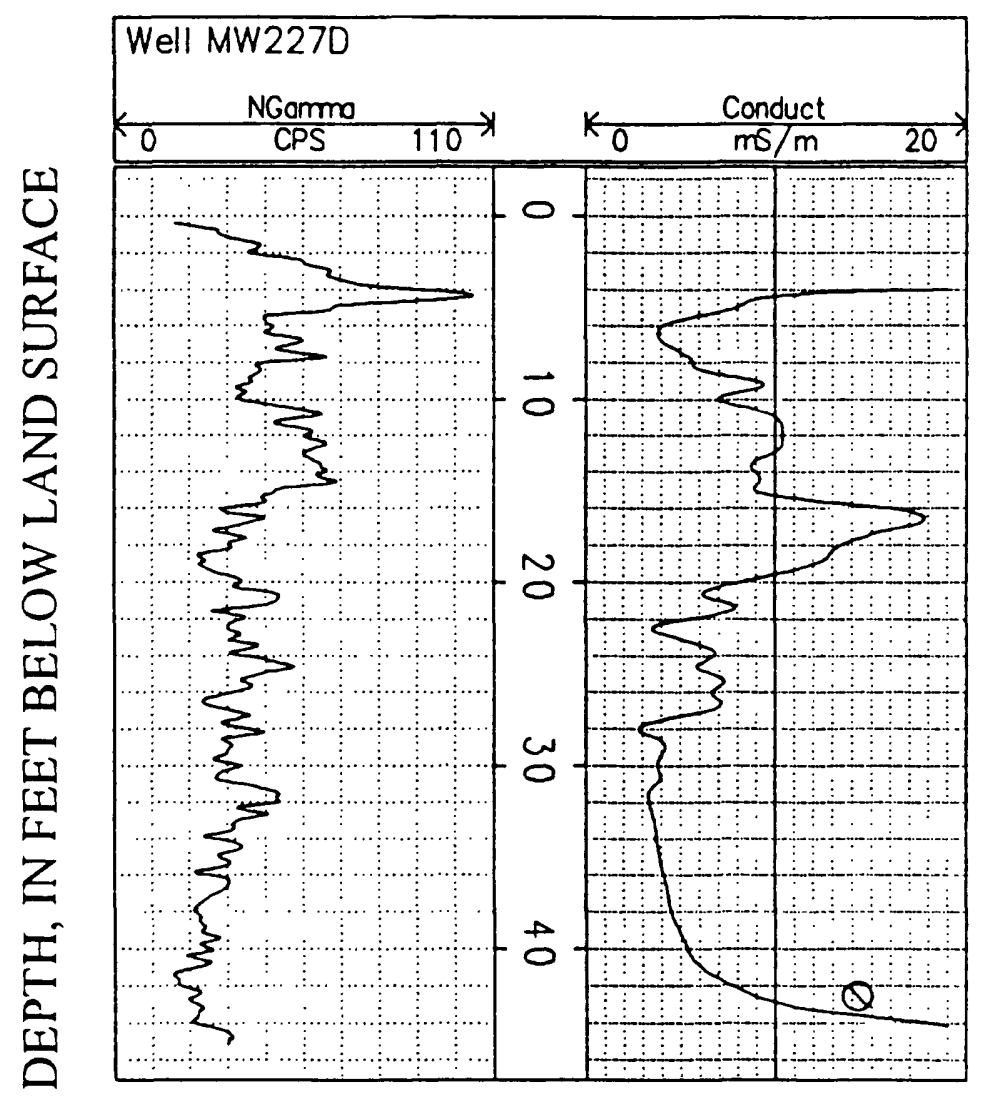

Geophysical logs at the natural-attenuation study area, Dover Air Force Base, Kent County, Delaware, for well MW227D. 